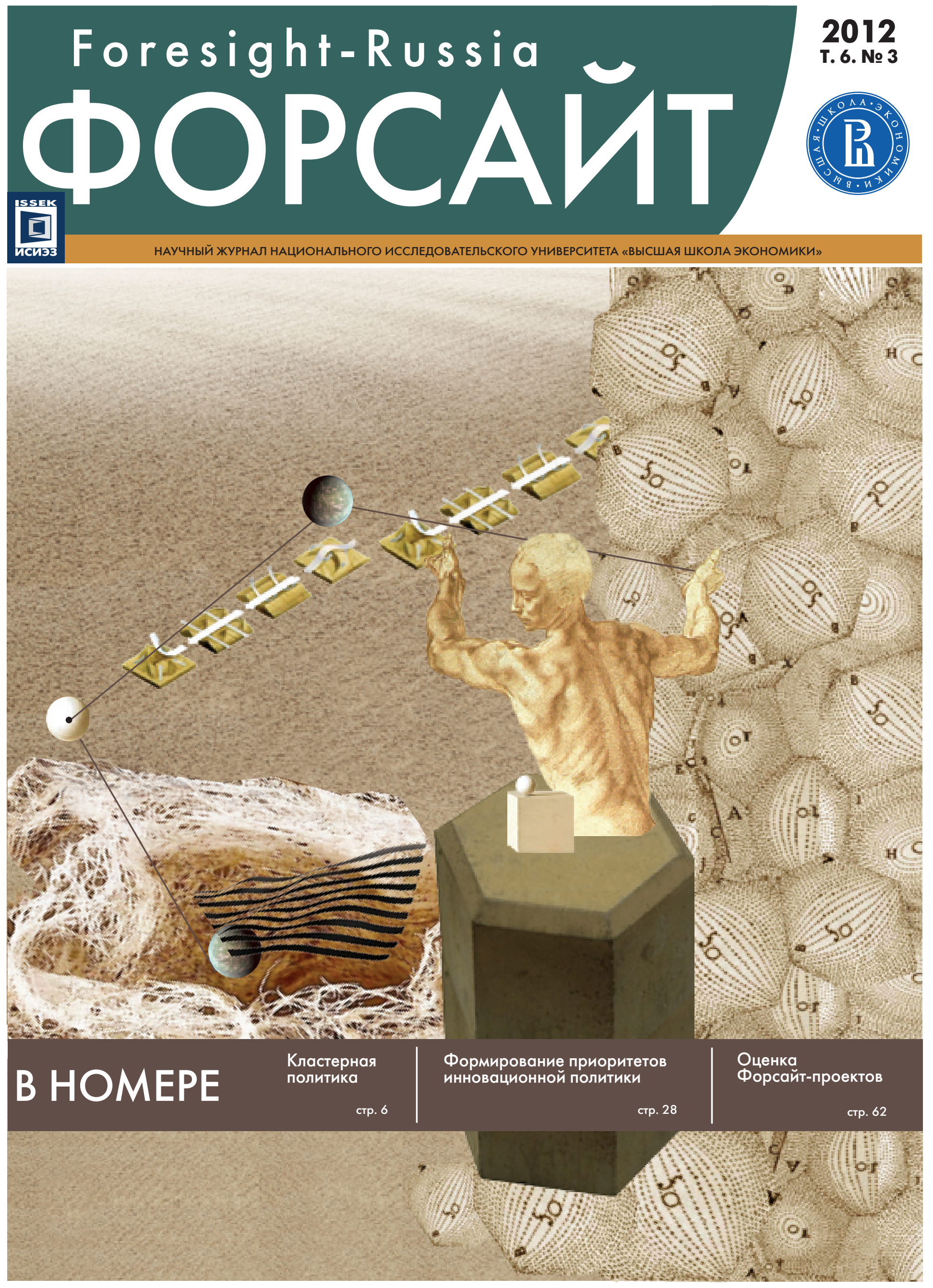




\section{$\int_{\text {Институ статистических }}$ \\ исседований изономоики}

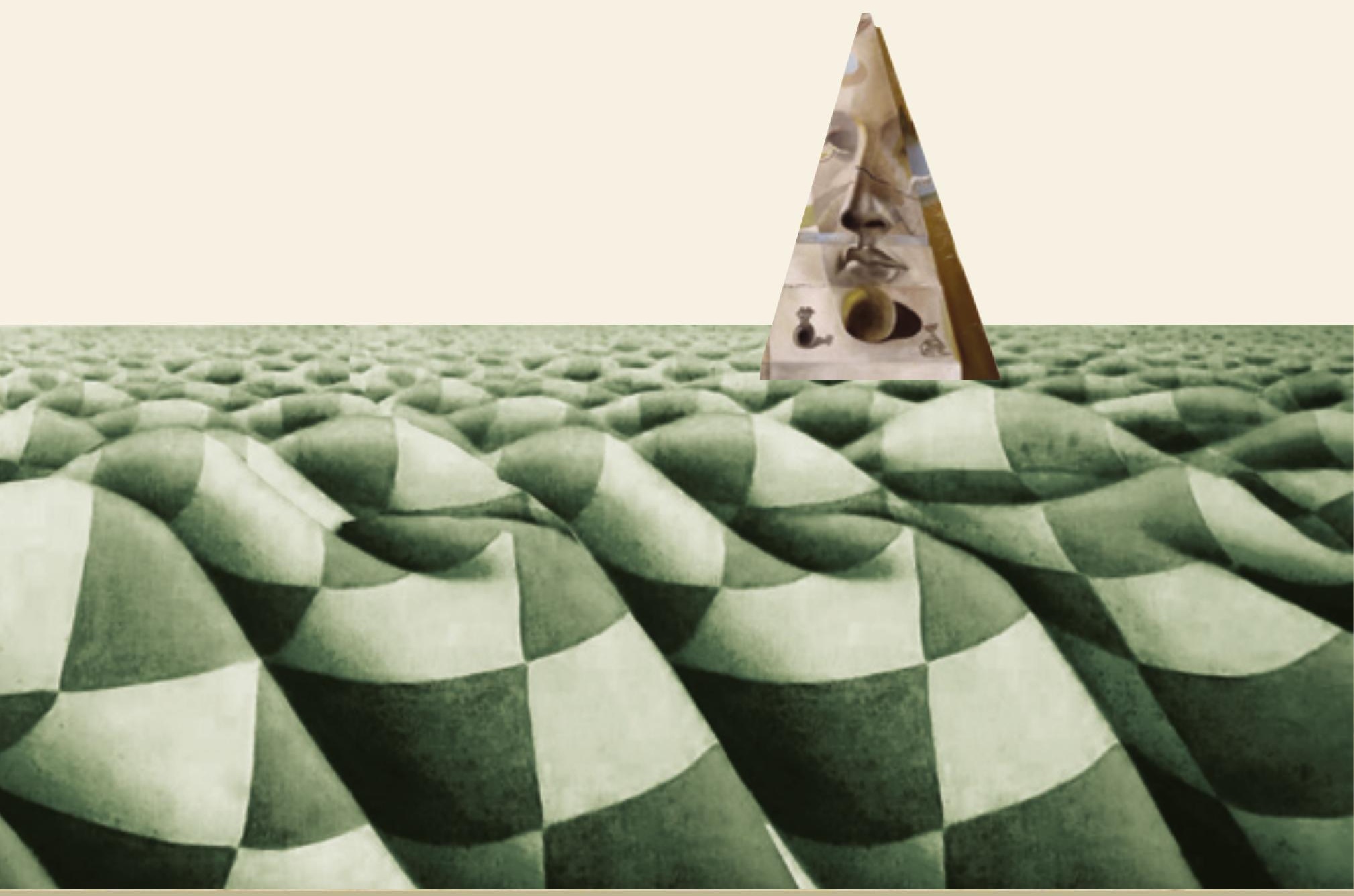




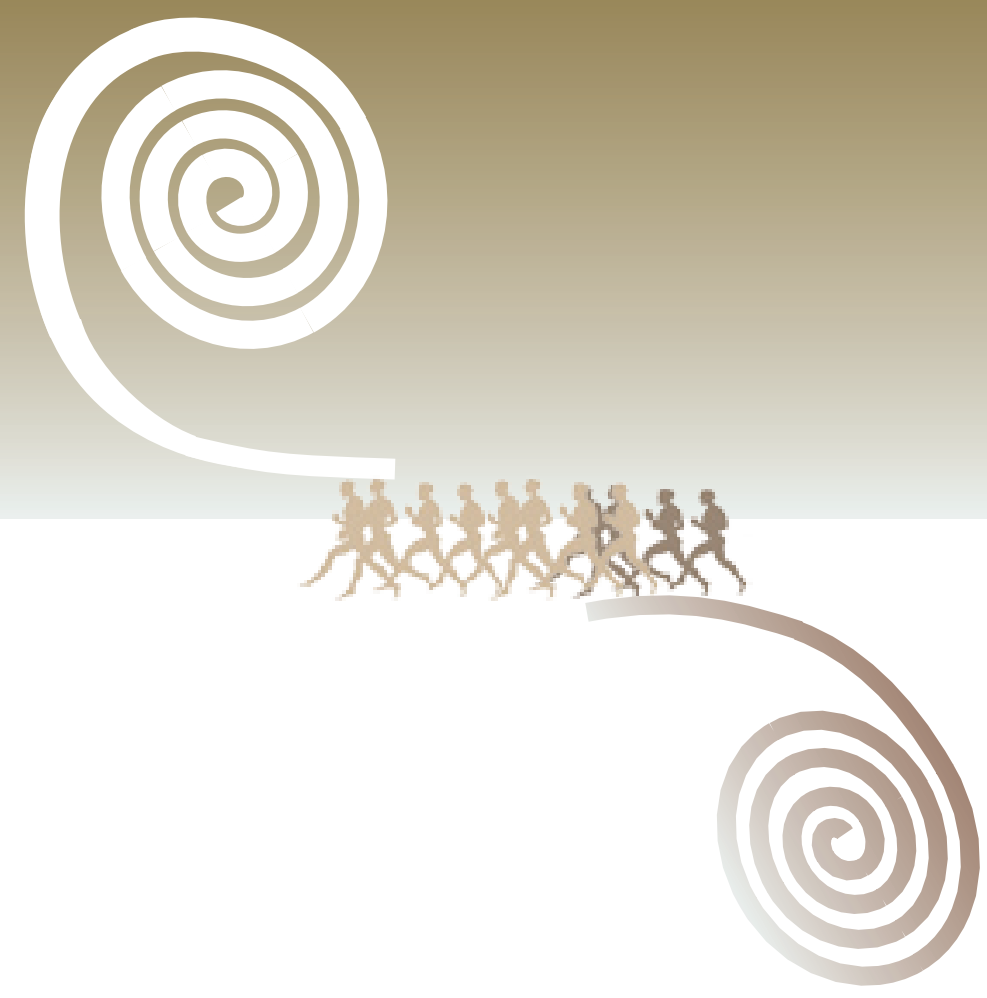

\section{ПОДПИСКА НАЖУРНАЛ ФОРСАЙТ}

\section{Издается с 2007 года}

В соответствии с решением Высшей аттестационной комиссии Министерства образования и науки Российской Федерации журнал «Форсайт» включен в перечень ведущих рецензируемых научных журналов и изданий, выпускаемых в Российской Федерации, рекомендованных для публикации основных научных результатов диссертаций на соискание ученой степени доктора и кандидата наук по направлению «Экономика» (протокол заседания президиума ВАК № 6/6 от 19 февраля 2010 г.).

Рейтинг журнала по импакт-фактору в Российском индексе научного цитирования за период 2008-2010 г.)

- Науковедение - 1

口 Организация и управление - 1

- Экономика - 3

\section{ПОДПИСНОЙ ИНДЕКС}

Агентство «Роспечать» 80690

«Пресса России»

\section{6}

\section{Стоимость подписки} на полугодие 880 руб. (включая НДС)

Журнал выходит ежеквартально

\section{БОНУС}

подписавшимся на четыре выпуска

\section{СТАТИСТИЧЕСКИЕ СБОРНИКИ}

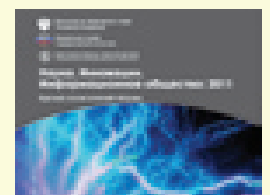

Наука. Инновации. Информационное общество

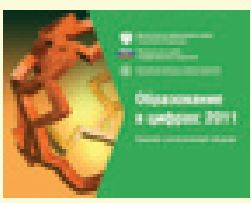

Образование в цифрах 


\section{ФОРСАЙТ}

ISSN

1995-459X

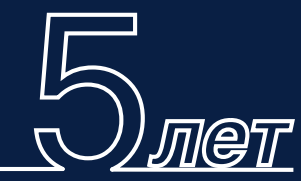

Периодичность выхода -4 раза в год

Главный редактор Л.М. Гохберг (НИУ ВШЭ)

Заместитель главного редактора А.В. Соколов (НИУ ВШЭ)

РЕДАКЦИОННАЯ КОЛЛЕГИЯ

Т.Е. Кузнецова (НИУ ВШЭ)

Д. Майсснер (НИУ ВШЭ)

M.В. Рычев (РНЦ «Курчатовский институт»)

Ю.В. Симачев (Межведомственный аналитический центр)

\section{РЕДАКЦИОННЫЙ СОВЕТ}

И.Р. Агамирзян (Российская венчурная компания)

А.Р. Белоусов (Минэкономразвития России)

Д. Гибсон (Техасский университет, США)

Ж. Гине (НИУ ВШЭ)

М. Кинэн (ОЭСР)

А.Н. Клепач (Минэкономразвития России)

М.В. Ковальчук (РНЦ «Курчатовский институт»)

Я.И. Кузьминов (НИУ ВШЭ)

К. Леонард (НИУ ВШЭ и Оксфордский университет,

Великобритания)

Дж. Линтон (Университет Оттавы, Канада)

Й. Майлс (НИУ ВШЭ и Университет Манчестера,

Великобритания)

С.Г. Поляков (Фонд содействия развитию малых форм предприятий в научно-технической сфере)

О. Саритас (Университет Манчестера,

Великобритания)

М. Сервантес (ОЭСР)

Л. Сюэ (Университет Цинхуа, Китай)

А.В. Хлунов (Администрация Президента РФ)

К. Шух (Центр социальных инноваций, Австрия)

\section{РЕДАКЦИЯ}

\section{Ответственный редактор}

М.В. Бойкова

Литературный редактор

Н.А. Гавриличева

Корректор

Н.В. Яровикова

Художник

М.Б. Зальцман

Верстка

М.Г. Салазкин

\section{Адрес редакции:}

109074, Москва, Славянская пл., 4, стр. 2, оф. 420-421

Национальный исследовательский университет

«Высшая школа экономики»

Телефон: +7 (495) 624-07-15

E-mail: foresight-journal@hse.ru

Web: http://foresight-journal.hse.ru

\section{Учредитель:}

Национальный исследовательский университет

«Высшая школа экономики»

Тираж 999 экз.

Отпечатано в ОАО «Можайский полиграфический комбинат», 143200, г. Можайск, ул. Мира, 93

www.oaompk.ru, www.oаoмпк.pф

тел. (495) 745-84-28, (49638) 20-685

() Национальный исследовательский университет «Высшая школа экономики»

\section{ИНДЕКС}

организаций, упомянутых в номере

Aud

Bayer

Bishop’s University, Канада

BMW

Centre for Innovation, Research and Competence in the Learning Economy
(CIRCLE), Lund University, Швеция

Concordia University (Kaнaga)

Evonik

Henkel

INTRA

Lufthanza Cargo

McGill University, Канада

Porsche

Stada

Академия медицинских наук Украины

Внешэкономбанк

Всемирный банк

Гарвардский университет (Harvard University)

Государственный комитет по науке и технологиям Украины

Государственный фонд фундаментальных исследований Украины

Департамент бизеса, инноваций и компетенций (Department for Business,
Innovation and Skills, BIS), Великобритания

Департамент инноваций, университетов и компетенций (Department for
Innovation, Universities and Skills, DIUS), Великобритания

Дрезденский технический университет (Dresden Technical University)

55

Евростат

ЗАО «Научно-производственная фирма ДНК-Технология» $\quad 56$

Институт научной информации (Institute for Scientific Information, ISI) 55

Институт прикладной фотоники (Institute for Applied Photonics), Германия

Институт статистических исследований и экономики знаний (ИСИЭЗ)

НИу ВШЭ

Институт им. Фридриха-Александра (Friedrich-Alexander-Universität

Erlangen-Nürnberg, FAU)

Кабинет министров Украины

$6,16,51,54,62$,

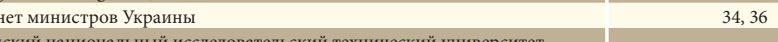

Казанский национальный исследовательский технический университет

Манчестерский институт инновационных исследований (Manchester
Institute of Innovation Research, MloIR)

\begin{tabular}{l|l} 
Maccaчyсетсский технологический институт (Massachusetts Institute of \\
Technology, MIT)
\end{tabular}

Министерство занятости и экономики Финляндии (Ministry of Employment

and Economy, MEE)

\begin{tabular}{|r|r|}
\hline Министерство науки и образования Украины & 34 \\
\hline
\end{tabular}

Министерство образования, досуга и спорта Квебека (Quebec Ministry of

Education, Recreation and Sports)

Министерство финансов Украины

Минобрнауки

Минфин России

Минэкономразииия России

(2) $21,23-25,53$

\begin{tabular}{|r|r|}
\hline Национальная академия наук Украины & $9,21,23-25,53$ \\
\hline
\end{tabular}

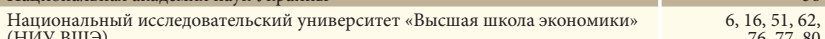

Национальный совет безопасности Украины

ООО «ПТФ Гидран»

\begin{tabular}{l|r}
\hline $\mathrm{OOO}$ «Аэросервис» & 57 \\
\hline
\end{tabular}

ООО «Век-21»

ООО «Наноструктурированные технологии стекла»

ООО «Научно-исследовательский центр высоких технологий» (НИЦВТ)

\begin{tabular}{lr} 
ООО «НПО «Кристалл» & 57 \\
\hline Организан сотруничества и развития (ОЭСР) & $41,76,77,79$
\end{tabular}

\begin{tabular}{l|r|}
\hline Организация экономического сотрудничества и развития (ОЭСР) & $41,76,77,79$ \\
\hline Парламент Украины (Верховная Рада) & $34-36$ \\
\hline
\end{tabular}

Правительство России $\quad 21,22,58$

Правительство Финляндии

\begin{tabular}{ll} 
Правительство Франции & 19 \\
\hline
\end{tabular}

Программа ООН по окружающе сене (UNEP) 23

Российская академия наук

Российская венчч)

\begin{tabular}{|l|l|}
\hline Российский фонд технологического развития & 23 \\
\hline
\end{tabular}

Российско-германская внешнеторговая палата

Сколковский технологический университет

\begin{tabular}{|l|l|}
\hline Совет по изучению производительных сил (СОПС) & 12 \\
\hline Совет по исследованиям и технологическим разработкам (Council for \\
\hline Research and Technological Development), Австрия
\end{tabular}

Совет по науке и технологиям Украины
Совет по научной и инновационной политике (Research and Innovation Policy

Украинская ақадемия сельскохозяйственных наук

Украинский институт научно-технической и экономической информации

Университет Осло, Норвегия

\begin{tabular}{l|l}
$\begin{array}{l}\text { Федеральное министерство образования и науки Германии } \\
\text { (Bundesministerium für Bildung und Forschung, BMBF) }\end{array}$ & $51,53,54,67,68$
\end{tabular}

Фонд Гете

Фонд инфраструктурных и образовательных программ 23

Фонд развития Центра разработки и коммерциализации новых технологий

Фонд развити
(«Сколково)

$\begin{aligned} & \text { Фонд содействия развитию малых форм предприятий в научно-технической } \\ & \text { сфере }\end{aligned} \quad 23,36,51,54$,
$57-60$

Центр исследований научно-технической политики Университета
Манчестера (PREST), Великобритания

Центр экспертизы исследований и оценки программ, Национальная

шкоол госурарственного управления (Centre d'expertise et de recherche en
évaluation de programmes (CREXE), Ecole nationale d'administration publiqu),

évaluation de programmes (CREX

ЮНЕСКО

ЮНИДО

ЮНКТАД

Японское агентство по международному сотрудничеству (Japan International
Cooperation Agency, JICA)

$65,66,70$ 40 


\section{СОДЕРЖАНИЕ}

T. 6, № 2 (2012)

Rus Eng

ENGLISH

About the journal

Contents

\section{СТРАТЕГИИ}

Метод «картирования

технологий» в поисковых

прогнозах

Д.Р. Белоусов, И.О. Сухареъа,

А.С. Фролов

Индикаторы

\section{ИННОВАЦИИ И ЭКОНОМИКА}

Стимулирование

инновационной деятельности

российских производственных компаний: новые возможности и ограничения

Д.С. Иванољ, М.Г. Кузык, Ю.В. Симачев

\section{Индикаторы}

Вьетнам в XXI веке:

развитие институтов научнотехнической и инновационной политики

A.C. Зайцева

\section{МАСТЕР-КЛАСС}

Мониторинг исследований

будущего

P. Ionnep

\section{соБытиЕ}

XII Международная научная конференщия НИУ ВШЭ по проблемам развития экономики и общества. Секция «Наука и инновации»

$44 \quad 55$

$17-$

T. 6, № 3 (2012)

Rus Eng

\section{ENGLISH}

About the journal

$-4$

Contents

$-5$

\section{СТРАТЕГИИ}

Рациональная кластерная

6

15

стратегия: маневрируя между

провалами рынка

и государства

Е.С. Куиенко

Кластерная политика в России: 1627 от теории к практике

В.Л. Абашкин, А.Д. Бояров, Е.С. Куизенко

\section{ИННОВАЦИИ И ЭКОНОМИКА}

Формирование приоритетов 28 39 инновационной политики и оценка их реализации: европейский опыт и уроки для Украины

Г. Румпф

\section{HAYKA}

Детерминанты продуктивности 40 научных исследований в сфере высшего образования: эмпирический анализ

Дж. Джейкоб, М. Ламари

Особенности участия малых предприятий в международной научно-технической кооперации: опыт российскогерманских контактов

М.А. Гериман, Т.Е. Кузнецзова

\section{МАСТЕР-КЛАСС}

Лучшие практики оценки научно-технологического 7680 Форсайта: базовые элементы и ключевые критерии

Е.А. Макарова, А.В. Соколова

\section{СОБЫтИЕ}

Взаимосвязи между акторами $76 \quad 81$ инновационной системы 


\section{Foresight Russia}

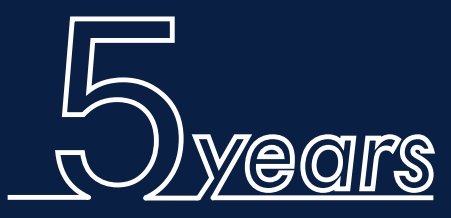

Foresight-Russia — a research journal that was established by the National Research University Higher School of Economics (HSE) and is administered by the HSE Institute for Statistical Studies and Economics of Knowledge (ISSEK), located in Moscow, Russia. The mission of the journal is to support the creation of Foresight culture in Russia through the dissemination of the best Russian and international practices in the field of future-oriented innovation development. It also provides a framework for a discussion of S\&T trends and policies. The following key issues are addressed:

- Foresight methodologies

- Results of Foresight studies implemented in Russia and abroad

- Long-term priorities of social, economic and S\&T development

- S\&T and innovation trends and indicators

- S\&T and innovation policies

- Strategic programmes of innovation development at national, regional, sectoral and corporate levels

- State-of-the-art methodologies and best practices of S\&T analyses and Foresight.

The target audience of the journal comprises research scholars, university professors, policymakers, businessmen, expert community, post-graduates, undergraduates and others who are interested in S\&T and innovation analyses, Foresight and policy issues.

Journal's rankings in the Russian Science Citation Index (two-year impact factor)

$$
\begin{aligned}
& \text { 1-st - Studies of Science } \\
& \text { 1-st - Management } \\
& \text { 3-rd - Economics }
\end{aligned}
$$

The journal is also represented in Ulrichsweb database.

The thematic focus of the journal makes it a unique Russian language edition in this field. Foresight-Russia is published quarterly and distributed in Russia and abroad.

\section{National Research University Higher School of Economics}

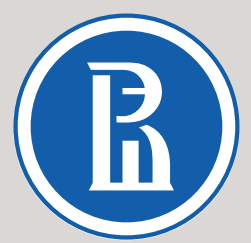

Institute for Statistical Studies and Economics of Knowledge

\section{EDITORIAL COUNCIL}

Leonid Gokhberg, Editor-in-Chief, First Vice-Rector, HSE, and Director, ISSEK, HSE, Russian Federation

Alexander Sokolov, Deputy Editor-in-Chief, HSE, Russian Federation

Igor Agamirzyan, Russian Venture Company, Russian Federation

Andrey Belousov, Ministry of Economic Development of the Russian Federation, Russian Federation

Mario Cervantes, Directorate for Science, Technology and Industry, OECD, France

David Gibson, The University of Texas at Austin, USA Jean Guinet, HSE, Russian Federation

Michael Keenan, Directorate for Science, Technology and Industry, OECD, France

Alexander Khlunov, Administration of the President of the Russian Federation, Russian Federation

Andrey Klepach, Ministry of Economic Development of the Russian Federation, Russian Federation Mikhail Kovalchuk, Russian Scientific Centre «Kurchatov Institute», Russian Federation

Yaroslav Kuzminov, HSE, Russian Federation

Carol S. Leonard, HSE and University of Oxford, United

Kingdom

Jonathan Linton, University of Ottawa, Canada

Ian Miles, HSE and Manchester University, United

Kingdom

Sergey Polyakov, Foundation for Assistance to Small Innovative Enterprises, Russian Federation

Ozcan Saritas, Manchester University, United Kingdom Klaus Schuch, Zentrum für Soziale Innovation, Austria Lan Xue, Tsinghua University, China

\section{EDITORIAL BOARD}

Tatiana Kuznetsova, HSE, Russian Federation Dirk Meissner, HSE, Russian Federation Mikhail Rychev, Russian Scientific Centre «Kurchatov Institute», Russian Federation Yury Simachev, Interdepartmental Analytical Centre, Russian Federation

\section{EDITORIAL STAFF}

Executive Editor - Marina Boykova Literary Editor - Nataliya Gavrilicheva Proof Reader - Nataliya Yarovikova Designer - Mariya Salzmann

Pre-Press - Mikhail Salazkin

\section{Our address:}

National Research University Higher School of Economics Office 420-421, 4 bld. 2, Slavyanskaya sq., Moscow, 109074, Russia Tel: +7 (495) 624-07-15

E-mail: foresight-journal@hse.ru

Web: http://foresight-journal.hse.ru 


\section{Periodicity - Quarterly}

\section{CONTENTS}

Vol. 6, No 2 (2012)
CONTENTS

Vol. 6, No 3 (2012)

\begin{tabular}{|c|c|c|}
\hline & Rus & Eng \\
\hline Contents & 3 & 5 \\
\hline $\begin{array}{l}\text { INFORMATION } \\
\text { on the Journal in English }\end{array}$ & - & 4 \\
\hline STRATEGIES & & \\
\hline $\begin{array}{l}\text { Applying Technology } \\
\text { Roadmapping to Exploratory } \\
\text { Forecasting }\end{array}$ & 6 & 16 \\
\hline $\begin{array}{l}\text { Dmitry Belousov, Alexander Frolov, } \\
\text { Irina Sukhareva }\end{array}$ & & \\
\hline Indicators & 17 & - \\
\hline
\end{tabular}

INNOVATION AND ECONOMY

Fostering Innovation

$18 \quad 41$

Performance of Russian

Manufacturing Enterprises: New

Opportunities and Limitations

Denis Ivanov, Mikhail Kuzyk,

Yury Simachev

Indicators

Vietnam in XXI Century:

Institutional Development of

S\&T and Innovation Policy

Anna Zaytseva

\section{MASTER CLASS}

Mapping Futures Studies

$56 \quad 74$

Rafael Popper

\section{EVENT}

XIII HSE International Academic 76

Conference on Economic and

Social Development. Section

«Science and Innovation»

International Foresight Academy
A Rational Cluster Strategy: Manoeuvring between Market and Government Failures

Evgeniy Kutsenko

Cluster Policy in Russia: From Theory to Practice

Rus Eng

\section{ENGLISH}

About the journal

$-4$

Contents

$-5$

\section{STRATEGIES}

Vasily Abashkin, Arthur Boyarov, Evgeniy Kutsenko

\section{INNOVATION AND ECONOMY}

Setting Priorities for Innovation 28

Policy and Evaluating Their

Performance:

Evidence from Europe and

Lessons for Ukraine

Gudrun Rumpf

\section{SCIENCE}

Factors Influencing Research

Productivity in Higher

Education: An Empirical

Investigation

Johann Jacob, Moktar Lamari

Specificities of Involving Small

Enterprises into International

S\&T Co-operation:

Evidence from the Linkages

between Russia and Germany

Mikhail Gershman, Tatiana Kuznetsova

\section{MASTER CLASS}

The Best Practices of Evaluating S\&T Foresight: Basic Elements and Key Criteria

Ekaterina Makarova, Anna Sokolova

\section{EVENT}

Linkages between Actors in the Innovation System 


\section{Рациональная кластерная стратегия:}

\section{маневрируя между провалами рынка и государства}

\section{Е.С. Куценко*}

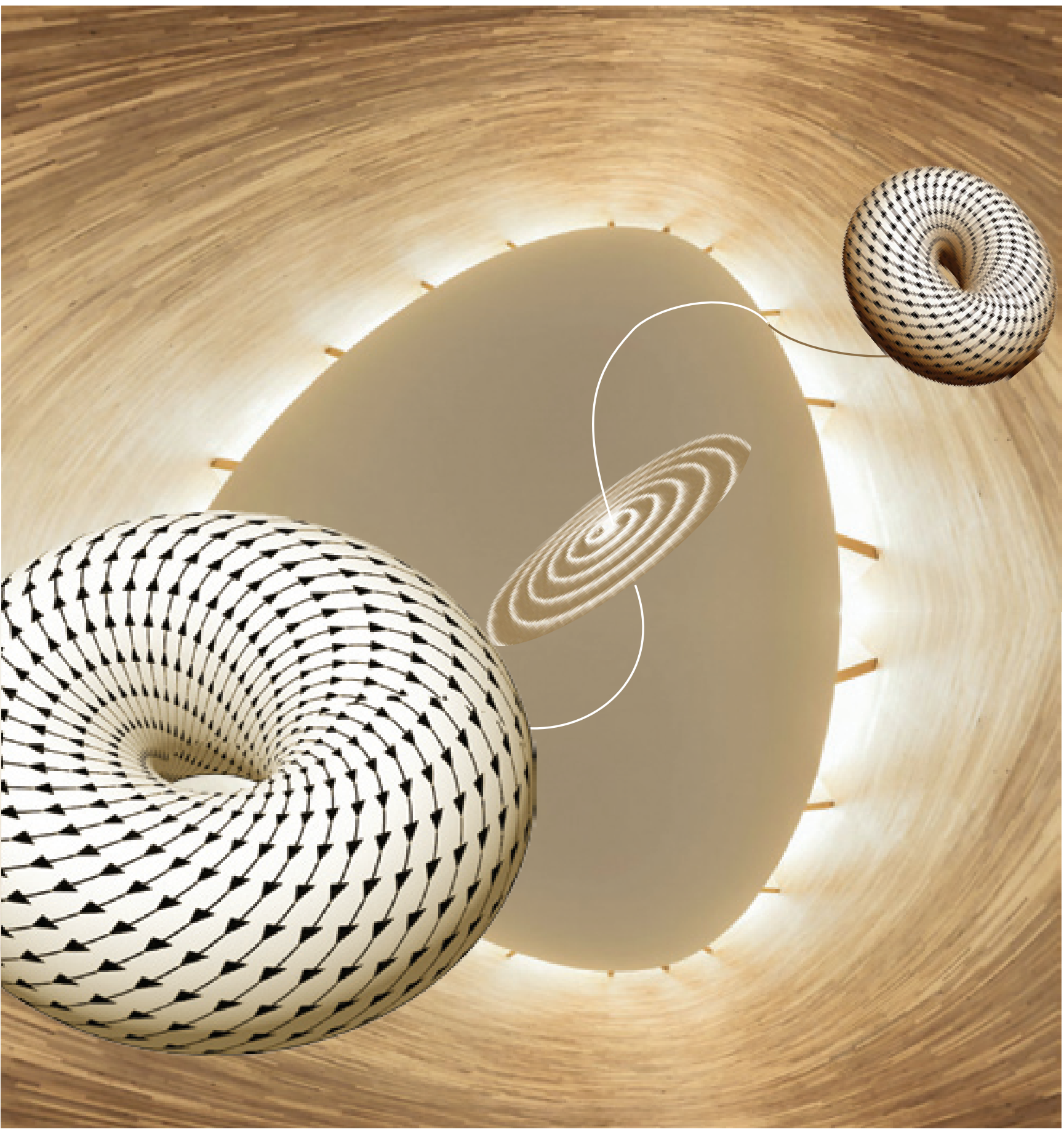

Вопрос о степени вмешательства государства в кластерную сферу сохраняет свою актуальность. Однако развитие кластеров не обеспечивается одними рыночными механизмами.

В статье затронута проблема рисков, снижающих эффективность государственной политики, и приводятся рекомендации по их преодолению.
* Куценко Евгений Сергеевич - старший научный сотрудник, Центр научно-технической, инновационной и информационной политики, ИСИЭЗ НИУ ВШЭ. E-mail: ekutsenko@hse.ru

Адрес: Национальный исследовательский университет «Высшая школа экономики», 101000, Москва, Мясницкая ул., 20.

\section{Ключевые слова}

кластерная политика; провалы государства; провалы рынка; размещение производительных сил. 
M ировой финансово-экономический кризис, разразившийся в 2008 г., наглядно продемонстрировал сильные и слабые стороны российской экономики. Предшествующее десятилетие стабильности способствовало скорее политическому и отчасти военному, чем экономическому усилению страны. Минусы сырьевой модели (зависимость от мировой конъюнктуры - цен на нефть, зарубежного заемного капитала и т. п.) подчеркивались и ранее, подобная «стабильность» восхищала далеко не всех, однако именно в кризис проблемы социально-экономического развития обнажились со всей остротой. Многие специалисты связывают их с низкими темпами ввода основных фондов, снижением квалификации рабочей силы, отсутствием стимулов у предпринимателей к внедрению инноваций, слабой ориентацией научных организаций на коммерциализацию результатов своей деятельности.

Темы модернизации и формирования инновационной экономики не теряют своей актуальности на протяжении долгого времени. Вместе с тем, говорить о достижении значительных успехов на этом пути пока еще рано. Поиск факторов, определяющих инновационное лидерство, привел к осознанию важности развития экономики на региональном уровне. Одним из важнейших подходов стала кластерная концепция. Ее истоки восходят к работам А. Маршалла, который отмечал, что географическая концентрация профессионалов в одной или близких видах деятельности способствует ускорению появления, распространения и практической реализации новых идей [Marshall, 1920]. Актуализированный в 1990-е гг., данный подход распространился в большинстве стран, включая Россию. В Концепции долгосрочного социально-экономического развития и Стратегии инновационного развития России, разработанных на период до 2020 г., предусматривается, что кластерная политика будет стимулировать рост конкурентоспособности бизнеса за счет эффективного взаимодействия участников кластера; расширения доступа к инновациям, технологиям, ноу-хау, специализированным услугам и высококвалифицированным кадрам; снижения трансакционных из держек; реализации совместных кооперационных проектов.

Формирование и развитие кластеров должно стать эффективным механизмом привлечения прямых иностранных инвестиций, интеграции национальных производителей в мировой рынок высокотехнологичной продукции.

Сегодня власть предпринимает практические шаги, воплощая в жизнь соответствующие меры: организованы конкурсы по отбору пилотных программ развития инновационных территориальных кластеров и их софинансированию ${ }^{1}$. Внедрение в практику этого инструмента представляется логичным в контексте как позитивного зарубежного опыта, так и российских инициатив по формированию «портфеля» взаимосвязанных политических механизмов. Поддержке кластеров отводится ключевая роль наряду с развитием инновационной инфраструктуры на базе высших учебных заведений; активизацией инновационной деятельности компаний с государственным участием; субсидированием научно-технической кооперации вузов и предприятий и пр.

Хотя кластерная риторика укрепилась в научном и политическом лексиконе, остается нерешенным ряд фундаментальных проблем, что сдерживает распространение данного подхода на практике. Необходимо определить рациональную основу кластерной политики, а также сферы и условия, в которых применение данного инструмента оправдано. Без серьезного осмысления кластерный подход рискует оказаться поверхностным, скорее ретуширующим проблемы, и быстро смениться другими «модными» концепциями, не оказав существенного влияния на решение задач инновационного развития в регионах.

В статье предпринята попытка внести вклад в поиск ответов на указанные вопросы. В первом разделе обосновываются проблемы участия государства в процессах формирования и развития кластеров. Во втором изложены специфические провалы рынка, связанные с этими процессами. Третья, заключительная часть описывает наиболее очевидные ошибки, которые могут снизить эффективность кластерной политики государства.

\section{Эмпирическое обоснование необходимости государственного вмешательства в процесс формирования кластеров}

Среди экспертов распространено мнение, что формирование кластеров - естественный процесс, и вмешательство государства, как минимум, неэффективно, а зачастую даже вредно [Дероше, 2011; Martin et al., 2008; Duranton, 2011]. Обширное исследование ван дер Линде показало, что из 700 кластеров только один (Синчу, Тайвань) является результатом целенаправленной политики [van der Linde, 2003]. $\Phi$. Мартин с коллегами, оценивая влияние кластерной политики во Франции, инициированной в 1999 г., на производительность поддерживаемых фирм ${ }^{2}$, выявил, что их совокупная факторная производительность в период с 1996 по 2004 г. даже упала на 5\% [Martin et al., 2010].

Другой теоретический анализ, проведенный Г. Дурантоном в отношении внешних эффектов, привел к выводу о несостоятельности кластерной политики (в трактовке М. Портера и приверженцев его подхода). Предлагаемые меры такой политики направлены на решение сложных и малоизученных проблем [Duranton, 2011, p. 40]. Более того, затраты на развитие кластеров зачастую расцениваются

\footnotetext{
1 Подробнее см. статью [Абашкин и др., 2012] ниже в настоящем номере журнала «Форсайт».

Речь идет о программе «Local Productive Systems» - первой инициативе по поддержке кластеров во Франции. В ее рамках выделялись субсидии в размере 37.5 тыс. евро в среднем на кластер, на достаточно мягких условиях: требовалось создать организацию, объединяющую участников кластера. Перечень целей получения субсидии был довольно широким - формирование общего бренда, поддержка экспорта и пр. В результате количество поддержанных кластеров оказалось настолько большим, что негативно повлияло на эффективность программы [Martin et al., 2010, p. 4].
} 
как неоправданные с точки зрения потенциальных результатов (даже если они достигнуты в полной мере $)^{3}$. По этой причине соответствующие инициативы были отнесены Г. Дурантоном к политике второго порядка, к которой обращаются только после решения более актуальных или простых проблем.

Полученные результаты вряд ли можно оценить однозначно. На практике, существует много примеров, когда активная кластерная политика государства приводила к успешному результату.

В основе создания кластера «с нуля» лежит, прежде всего, возможность привлечения людей и организаций, которые специализируются на каком-либо важном для региона или страны виде деятельности. Как показывает опыт, ряд новых отраслей сформировались именно благодаря целенаправленным действиям государства. Интересный кейс демонстрирует Германия [Кулишер, 2004, с. 167]. Так называемое «промышленное воспитание» нации стало краеугольным камнем немецкой экономической теории и практики, благодаря чему к началу XX в. страна обрела статус «индустриального чемпиона» Европы, потеснив по многим направлениям Англию. Характерно, что исследователи кластеров подобные примеры не рассматривают, поскольку в основном изучают слишком короткий по историческим меркам период - в лучшем случае последние 50 лет.

Современные «новые» отрасли, как показывает практика развитых стран, также не возникают спонтанно. Опыт развития «творческих» (creative) секторов в Великобритании ${ }^{4}$ свидетельствует, что, во-первых, они относятся к приоритетам политики городских властей. Во-вторых, для успешной реализации таких проектов требуется продуманная система поддержки, включающая льготную аренду, систему микрокредитов, венчурные инвестиционные фонды, постоянное консультирование малых компаний по вопросам ведения бизнеса. В-третьих, важным элементом инновационной инфраструктуры являются специальные агентства - посредники между сообществом творческих предпринимателей и городскими властями, которые позволяют сохранять баланс в системе [Гнедовский, 2005, с. 2].

Заметим, что поддержка государства в области развития новых видов деятельности никогда не распылялась по всей стране, а локализировалась на определенных территориях, что опровергает мнение о спонтанных действиях государства и о преобладании естественной (эволюционной) модели кластеризации.

Помимо привлечения специалистов, развитие кластера подразумевает налаживание кооперационных связей, повышение инновационной активности хозяйствующих субъектов. Последняя в долгосрочной перспективе «подпитывается» фундаментальной наукой, которая является сферой государственной ответственности. В современном мире доля госсектора в расходах на исследования и разработки (ИиР) составляет 39\% (по состоянию на 2006 г.), что является довольно высоким показателем [Jaruzelski, Dehoff, 2007, p. 4]. Ряд кластеров (Кремниевая Долина, образовательный кластер вокруг Бостона - Гарвард (Harvard University), Массачусетсский технологический институт (Massachusetts Institute of Technology, MIT) и др.) во многом сформировались именно за счет значительного государственного финансирования научной деятельности.

Тем не менее приведенные примеры не дают четкого ответа на вопрос: насколько эффективным может быть участие государства в кластерных процессах? В реальности случаи планомерного успешного создания кластера «с нуля» в последние десятилетия встречаются редко. Часто приводимый пример Research Triangle в Северной Каролине (США) скорее демонстрирует неоднозначность государственного вмешательства, так как подобные кластеры за длительный период «вызревания» поглотили колоссальные объемы бюджетных средств [Ketels, 2003, p. 15]. Однако еще сложнее назвать примеры кластеров, в развитии которых государство не принимало участия (в той или иной форме). Поскольку формирование кластеров обычно занимает продолжительное время (до нескольких десятилетий), оценка результатов политики в этой области за первые годы реализации вряд ли будет объективной. Более того, отказ государства от вмешательства в процесс вовсе не гарантирует, что «невидимая рука рынка» организует людей и предприятия в пространстве оптимальным образом.

Подытоживая сказанное, можно заключить: невозможно однозначно судить о степени эффективности участия государства в создании и развитии кластера, основываясь на опыте конкретной страны. К тому же в реализации подобных инициатив наряду с государством активно участвуют бизнес и научное сообщество, что еще больше затрудняет оценку контекста формирования тех или иных кластеров: с помощью действий государства либо вопреки им. Проанализируем поставленные вопросы с теоретической точки зрения.

\section{Провалы рынка и развитие кластеров}

Проблема оценки реального вклада государства в формирование и продвижение кластеров относится к общим вопросам его вмешательства в экономику в целом. Она характерна для любого направления экономического регулирования, включая макроэкономическую политику ${ }^{5}$, где инициативы

${ }^{3}$ Многочисленные эмпирические исследования, оценивающие влияние кластеров (локализационные эффекты) и городов (урбанизационные эффекты) на производительность, оплату труда и инновационную активность фирм, показывают, что вопреки изначальным теоретическим предположениям, оно не так ощутимо. Если говорить о количественной оценке влияния внешней экономии на производительность, то эластичность последней по размеру города и от расли в регионе колеблется между 3 и 8\% [Martin et al., 2008, p. 2]. Заметим, что методология таких исследований обладает рядом недостатков. Об одном из них речь идет в работе [Куценко, 2012].

${ }^{4}$ Данное понятие закреплено в законодательстве Великобритании и определяется как «...деятельность, в основе которой лежит индивидуальное творческое начало, навык или талант, и которая может создавать добавленную стоимость и рабочие места путем производства и эксплуатации интеллектуальной собственности. К творческому сектору относятся: реклама, архитектура, художественный и антикварный рынок, ремесла, дизайн, мода, производство кино- и видеопродукции, программирование, в том числе создание развлекательных интерактивных программ и компьютерных игр, музыка, исполнительские искусства, издательское дело, теле-, радио- и интернет-вещание» [Гнедовский, 2005, с. 1-2].

5 В монетарной политике остро стоят проблемы временного лага (разрыв между мероприятием и его результатом из-за сложности и возможных сбоев в механизме денежной трансмиссии); дилеммы целей (невозможность одновременно регулировать предложение денег и ставку процента) и т. д. Фискальная политика сталкивается с временными сложностями, а также факторами неопределенности (эффекты сочетания тех или иных инструментов регулирования в конкретной ситуации), вытеснением частных инвестиций и пр. 
проработаны на порядок лучше, чем на кластерном уровне. Они опираются на систему сбора и анализа статистики, реализуются через специализированные органы исполнительной власти (в России - это, пре жде всего, Минэкономразвития и Минфин). Тем не менее провалы деятельности государства на макроуровне вряд ли случаются реже, чем истории успеха.

Возникает вопрос: почему проблема оценки результативности действий государства не препятствует развитию многих направлений экономической политики? Ответ заключается в том, что в экономической науке государственное вмешательство принято обосновывать выявлением так называемых провалов рынка 6 . Если они объективно существуют, а инициативы государства направлены на их преодоление, то такие действия можно считать теоретически обоснованными. При подобном подходе эмпирические свидетельства о неудачах отдельных стран в конкретные временные периоды не могут опровергнуть необходимость государ ственного регулирования ${ }^{7}$. Другими словами, если монетарная или фискальная политика конкретных государств (и даже их большинства) не является успешной, это не означает, что подобная стратегия неэффективна или вредна в принципе.

По нашему мнению, к провалам рынка в отношении процессов формирования, развития и упадка кластеров относятся ситуации двух типов:

- несоответствие территориального размещения производительных сил существующим центростремительным и центробежным агломерационным эффектам (положительным и отрицательным внешним экономиям);

- недопроизводство локализованными экономическими агентами положительной внешней экономии, обусловленной не полным ее отражением на результатах хозяйственной деятельности этих агентов.

Рассмотрим каждый из типов провалов рынка более подробно, начав с первого. В результате ряда событий и тенденций (научно-технический прогресс, снижение транспортных издержек, изменение внешнеполитической ситуации, нарастающие процессы глобализации и др.) относительная привлекательность кластера для предприятий может измениться. В случае ее уменьшения происходит ослабление относительного агломерационного эф фекта в определенном виде деятельности или регионе. В теории изменения приводят к соответствующим сдвигам в размещении производительных сил: фирмы, стремясь максимизировать прибыль, должны переместиться в более успешный кластер с высоким суммарным агломерационным эффектом. Но в реальности не стоит торопиться с подобными прогнозами: изменения в размещении производительных сил связаны с крупными издержками и осуществляются с заметным временным лагом.

Наиболее актуальными для многих секторов являются инновационные преимущества от агломерации ${ }^{8}$ По причине своей краткосрочности они требуют постоянной поддержки. И даже в этом случае агломерация способна тормозить инновационную активность участников ${ }^{9}$. На практике встречаются ситуации, когда суммарный агломерационный эффект отрицателен, но географическая концентрация в определенной сфере сохраняется.

Имеет место и обратная картина - новые возможности (экономия на производственных издержках, институциональные и инновационные преимущества) не используются, так как не подкрепляются перемещением производительных сил.

Несмотря на реалии рыночной экономики (даже если речь идет о совершенной конкуренции), территориальное размещение производительных сил может оказаться устойчиво неоптимальным. Подобная проблема не решается в краткосрочном периоде. Описанная закономерность, по мнению автора, похожа на зависимость от предшествующего развития (path dependency - «эффект колеи») [David, 1985; Arthur, 1994; Margolis, Liebowitz, 1998]. Данный эффект был выявлен применительно к развитию технологий и институтов, но он наглядно отражает инерционность размещения производительных ресурсов. В табл. 1 рассмотрены причины, объясняющие устойчивость состояния неэффективного равновесия в отношении технологий, институтов, пространственного размещения.

Причинами возникновения неэффективного равновесия при развитии кластеров могут стать как изначальные ошибки в пространственной локализации, так и объективные изменения в агломерационных эффектах с течением времени. Дополнительный фактор - ситуация, когда рационально действующая фирма отказывается от оптимизации своего размещения, поскольку это требует коллективных действий в условиях высоких трансакционных издержек [Duranton, 2011]. Проиллюстрируем подобную ситуацию абстрактным примером.

Предположим, компания дислоцирована не оптимально, и размер кластера, к которому она относится, превышает допустимый, вследствие чего центробежные силы, связанные с ценами на землю, недвижимость, оплатой труда персонала, перекрывают

\footnotetext{
${ }^{6}$ Мы рассматриваем провалы рынка не в онтологическом смысле (традиция А. Пигу), а как следствие трансакционных издержек, нечеткой спецификации прав собственности и наличия эффекта богатства [Коуз, 1993; Скоробогато6, 2006]

7 Это очевидно, поскольку индуктивный метод, в отличие от дедуктивного, не позволяет получить строгие доказательства.

8 Как правило, в кластере можно ожидать появления таких инновационных преимуществ, как снижение издержек доступа к новым знаниям (которые имеют значительную скрытую часть (tacit knowledge) и эффективно распространяются через личный контакт): создание инноваций (распространение нового знания, концентрация его носителей); увеличение скорости их внедрения за счет формирования соответствующей среды; повышение уровня инновационной активности фирм за счет «входящих» инноваций из других компаний либо под влиянием усиливающейся конкуренции.

9 Существует гипотеза, согласно которой географически сконцентрированные фирмы демонстрируют непропорционально высокий уровень инновационной активности на этапе роста отрасли. Напротив, для компаний, не входящих в кластеры, ее повышение характерно на более поздних стадиях [Menzel, Fornahl, 2007 , p. 5]. Одной из причин снижения активности является недостаток разнообразия в кластере, препятствующий возникновению новых идей. С течением времени интеллектуальные модели (mental model) поведения совместно локализованных игроков все в большей степени приближаются друг к другу и фоку времени интеллектуальные модели (mental model) поведения совместно локализованных игроков все в большей степени приближаются друг к другу и фокусируются на успешной в прошлом траектории. Возникает эффект блокировки. Эмпирические исследования, проведенные в США, показали, что технологиче-
ское разнообразие (heterogeneity) существует на различных этапах жизненного цикла отрасли, но в разных форматах пространственного размещения: в рамках штата на ранних этапах жизненного цикла и между штатами на стадии зрелости. Другими словами, компании постепенно «сходятся» в сфере технологии в рамках одного региона и остаются разнородными при межрегиональных сравнениях [Rigby, Essletzbichler, 2006].
} 


\begin{tabular}{|l|l|l|}
\hline \multicolumn{2}{|c|}{ Табл. 1. Факторы зависимости от предшествующего развития (эффекта колеи)* } \\
\hline \multicolumn{1}{|c|}{ Технологии } & \multicolumn{1}{|c|}{ Институты } \\
\hline Техническая взаимозависимость & $\begin{array}{l}\text { Пнституциональная } \\
\text { взаимозависимость }\end{array}$ & $\begin{array}{l}\text { Взаимозависимость фирмы от местных } \\
\text { производительных сил }\end{array}$ \\
\hline Рост отдачи от масштаба & Сетевые эффекты & $\begin{array}{l}\text { Рост внешней экономии при увеличении } \\
\text { кластера }\end{array}$ \\
\hline $\begin{array}{l}\text { Долговечность капитального } \\
\text { оборудования (квазинеобратимость } \\
\text { инвестицй })\end{array}$ & $\begin{array}{l}\text { Квазинеобратимость первичной } \\
\text { социализации (или социального } \\
\text { капитала) }\end{array}$ & $\begin{array}{l}\text { Квазинеобратимость первичного } \\
\text { территориального размещения. }\end{array}$ \\
\hline $\begin{array}{l}\text { Неравномерность роста отдачи } \\
\text { технологии }\end{array}$ & $\begin{array}{l}\text { Неравномерность роста отдачи } \\
\text { института }\end{array}$ & $\begin{array}{l}\text { Неравномерность роста внешней } \\
\text { экономии от функционирования } \\
\text { в кластере }\end{array}$ \\
\hline $\begin{array}{l}\text { * Подробнее см.: [Куценко, 2012, с. 20-21]. } \\
\text { Источники: [Латов, 2005]; автор (последний столбец). }\end{array}$ & \\
\hline
\end{tabular}

центростремительные. Пусть охват альтернативных кластеров также чрезмерен. В этом случае было бы рационально повысить равномерность распределения производительных сил (фирм) в данной сфере деятельности, уменьшив размеры существующих кластеров и увеличив их число. Однако каждая компания (или конкретный работник) в отдельности не захочет перемещаться в другое место с целью формирования нового кластера, который первоначально будет небольшим и не сможет генерировать необходимую внешнюю экономию (строго говоря, его вообще нельзя считать кластером), тогда как переезд потребует затрат. Для создания новых кластеров или оптимизации существующих потребуются согласованные действия множества компаний и людей. Кроме того, может оказаться, что издержки этого согласования с другими игроками для фирмыинициатора превысят будущие выгоды от высокой внешней экономии, обусловленные оптимизацией.

Второй тип провалов рынка, связанный с образованием и развитием кластеров, отражает ситуацию, когда экономические агенты оказывают недостаточный положительный внешний эффект, что ведет к снижению общей результативности кластера.

Как отмечалось выше, причина недопроизводства подобных эффектов заключается в том, что они не в полной мере отражаются на показателях хозяйственной деятельности фирм. У рациональных производителей отсутствуют стимулы к созданию бесплатных благ для третьих лиц.

Провалы второго типа делятся на три группы в зависимости от механизма получения внешней экономии: совместное участие в выгодах (sharing), подбор (matching), обучение (learning) [Duranton, Puga, 2004].

Первая группа проблем возникает из-за необходимости разделения выгод между участниками от внешних эффектов деятельности кластера. Так, если новые игроки содействуют росту разнообразия, то маловероятно, что они смогут воспользоваться в полной мере собственными преимуществами.

Второй набор связан с функционированием механизма подбора контрагентов, который, прежде всего, проявляется на рынке труда. В кластере концентрируются спрос и предложение; фирмы и потенциальные работники получают шанс заключить наиболее подходящий контракт. При этом компании упускают положительный эффект, оказываемый ими на возможности соискателей вакансии.
Не обязательно, что последние выберут конкретную фирму, но сама конкуренция между организациями кластера, безусловно, положительно влияет на условия труда.

Третий комплекс проблем заключается в том, что фирмы не имеют возможности в полной мере использовать выгоды от системы обучения, действующей в кластере. Например, компании могут быть не заинтересованы инвестировать в процесс диффузии инновации, так как выигрыш здесь зависит в том числе от действий других участников и не может быть полностью получен инвестором. Они неохотно вкладывают деньги в развитие персонала, учитывая, что кадры могут в будущем легко перейти к конку ренту, даже не переезжая в новый город и не меняя специализацию [Duranton, 2011].

Итак, очевидно, что «естественное» (без участия государства) развитие кластеров не всегда происходит оптимально. В силу описанных выше провалов рынка территориальное размещение производительных сил может оказаться устойчиво невыгодным. Но даже если оно оптимальное, вероятно, что участники не в полной мере используют возможности кластерной кооперации. Провалы рынка приводят к тому, что одни хозяйствующие субъекты оказываются менее производительными и, в конечном счете, менее конкурентоспособными, чем другие (в иных странах и регионах, где провалы не столь масштабны). Следствиями такого разрыва в производительности могут быть: перемещение наиболее конкурентоспособных национальных компаний за рубеж; ликвидация производств в стране; протекционистская защита национального производителя (что означает дополнительный налог со всего общества, вероятность дальнейшего ослабления национальных фирм при слабой конкуренции и пр.). Очевидно, что с точки зрения государства с сильными провалами рынка такая «естественная эволюция» нежелательна.

Проведенный анализ позволяет утверждать, что при прочих равных условиях вмешательство государства в процессы формирования и развития кластеров необходимо. Причем направления и инструменты политики должны формулироваться с учетом типичных проблем поддерживаемых государством кластеров. Вместе с тем само по себе такое регулирование не гарантирует успех; возможно даже, что вместо пользы будет нанесен вред. Далее будут рассмотрены наиболее вероятные риски, возникающие при реализации кластерной политики. 


\section{Причины и риски снижения эффективности политики}

По нашему мнению, выделяется ряд базовых причин потенциальной неэффективности кластерной политики государства:

- сложность объективной оценки внешних эффектов (синергии в кластере) и связанные с этим трудности идентификации «провалов рынка»;

- асимметрия информации между органами власти, ответственными за реализацию кластерной политики, и группами хозяйствующих субъектов, претендующих на поддержку;

- рентоориентированное поведение (сговор чиновников и групп специальных интересов по поводу распределения государственной поддержки).

Рассмотрим наиболее очевидные риски, связанные с реализацией кластерной политики (провалы государства).

Несоответствие регулирующих мер имеющимся проблемам

Меры кластерной политики очень разнородны. Не существует универсального набора, применимого к развитию любого кластера. Комплекс мер должен соответствовать проблемам, выявленным в случае каждого конкретного объединения. При этом провалы рынка сами по себе плохо изучены и идентифицированы; некоторые далеко не всегда могут явиться объектом регулирования на национальном (федеральном) уровне. Способны ли «совладать»с ними региональные власти, реализующие кластерную политику, остается вопросом [Duranton, 2011].

Инструменты, направленные на решение проблем на местном рынке труда (механизм подбора контрагентов в кластере), не имеют ничего общего с усилиями по ускорению диффузии инноваций (механизм обучения в кластере). Причем некоторые меры - специализированное обучение и тренинги, университетские исследовательские программы, развитие транспортной инфраструктуры и др. ${ }^{10}$ - крайне затратны. В результате значительные средства тратятся на устранение плохо идентифицированных провалов рынка [Duranton, 2011].

Государство может серьезно подорвать в долгосрочной перспективе инновационную активность предприятий, гарантировав им «тепличные» условия: налоговые льготы, завышенные тарифы и пошлины для товаров иностранных конкурентов, постоянное размещение заказа, статус естественной монополии и пр. Эти эффективные в ряде случаев подходы несут риск снижения конкурентного давления и, следовательно, инновационной активности. Излишний патернализм способен вызвать потерю интереса отдельных субъектов потенциального кластера к тесной кооперации ${ }^{11}$. В этом видится главная трудность коммерциализации технологий, которыми обладают российские научные и образовательные организации.
Государство не должно замещать собой естественным образом формирующиеся хозяйственные связи, но выступать посредником для их возникновения и развития.

Конфликт кластерных инструментов с мерами региональной политики

Г. Дурантон подробно анализирует «рецепт» М. Портера по развитию кластеров, который заключается в устранении входных барьеров. Данная рекомендация противоречит распространенной практике планирования и зонирования территориального развития (применяемой в мегаполисах или на территориях со статусом культурного наследия или заповедной зоны).

Отмена практики зонирования может привести к резкому ухудшению условий жизнедеятельности хозяйствующих субъектов и населения [Duranton, 2011]. В результате отрицательные внешние эффекты усилятся, что вызовет рост издержек участников кластера и даже его упадок. Вероятно, что отмена зонирования скажется и на местных жителях, вынужденных оплачивать своими налогами подобные неэффективные инициативы.

\section{Преобладание затрат на изменение структуры территориального размещзения производства над выгодами}

Поскольку агломерационные эффекты, возникающие в кластерах, с трудом поддаются измерению, стоимость перемещения или привлечения предприятий может превзойти ожидания от растущих агломерационных эффектов. С этой проблемой тесно связан следующий риск.

\section{Увеличение кластера сверх оптимального размера}

Политика, направленная на увеличение размеров кластеров (путем привлечения новых фирм и работников), не всегда эффективна. Считается, что существует его оптимальный размер, при котором чистый агломерационный эффект максимален ${ }^{12}$. Превышение оптимума приводит к росту издержек (цены на землю, недвижимость, оплату труда, проблемы с транспортировкой из-за пробок и пр.). В итоге, политика, направленная на неконтролируемый рост кластеров, может лишь подорвать конкурентоспособность их участников.

\section{Чрезмерный акиент на проблемах территориального размещзения в ущерб развитию инновационной деятельности}

Специалисты в области экономической географии рассматривают проблему кластеризации экономики, как правило, через призму оптимизации размещения производительных сил (увеличение концентрации фирм и человеческих ресурсов, объединенных общими интересами).

Однако, как мы уже определили, изменения в системе территориального размещения произво-

\footnotetext{
${ }^{10}$ Меры перечислены М. Портером в качестве инструментов, способствующих развитию кластеров: [Porter, 2000].

${ }^{11}$ Например, в России многие крупные компании, НИИ, вузы, финансовые организации делают ставку, скорее на государственную поддержку как основной источник собственного благополучия, нежели на бизнес-кооперацию.

${ }^{12}$ Ряд исследований доказывает нелинейное влияние эффектов локализации (связь в форме перевернутой буквы U) [Martin et al., 2008; Vorobyev et al., 2010].
} 
дительных сил весьма капиталоемкие. Плюс к этому, в силу зависимости от предшествующего развития сдвиги в территориальном размещении всегда «запаздывают» по сравнению с центростремительными и центробежными трендами. Наконец, простое «механическое» перемещение связано лишь с небольшим приростом производительности (см. сноску 5 ранее).

Таким образом, акценты кластерной политики должны ставиться не столько на привлечении новых игроков, сколько на развитии актуальных видов внешней экономии и повышении уровня их абсорбции ${ }^{13}$ участниками кластера. Среди инструментов отметим содействие самоорганизации местных игроков (бизнес, образование, наука); реализацию совместных проектов; развитие формальных и неформальных сетей; накопление акторами социального капитала; формирование объектов инновационной инфраструктуры и т. п. ${ }^{14}$

Оиибочный выбор приоритетов или объектов поддержки

Существует риск сделать ставку на «инновационный» кластер, не обладающий достаточным потенциалом в регионе (малая доля занятости, отсутствие связей с другими секторами, невостребованность продукции). С ростом популярности кластерной политики в мире многие регионы предпочитают развивать кластеры исключительно в «модных» областях биотехнологий или информационных технологий. В частности, в России существует опасность чрезмерного увлечения «нанотехнологическими» кластерами.

Распространена ситуация взаимоисключающих приоритетов для одной территории (поддержка нефтедобывающей и химической промышленности, с одной стороны, и развитие туристических кластеров, с другой $)^{15}$. Риски появляются и при излишне широком профиле деятельности (предполагается одновременное развитие ИКТ, био-, нанотехнологий, ядерной энергетики, энергоэффективности и т. п.). Подобный разброс может быть оправдан только для центров производства знаний (например, наукоградов) за счет исключения либо редукции производственной составляющей. Развитие последней влечет необходимость специализации, так как разные сферы деятельности требуют соответствующей производственной и научной инфраструктуры, профильных научных и образовательных учреждений, квалифицированного персонала и пр. Кластер, в отличие от центров производства знаний, специализирован, поскольку совмещает науку и производство, в идеале концентрируя всю цепочку создания нового продукта.

Распространенной ошибкой является поддержка неперспективных и даже деградирующих кластеров. Инвестируя в них, государство (с большой вероятностью) будет лишь продлевать агонию нежизнеспособных образований, цементировать неэффективную локализацию экономической активности. Подобный вектор может нарушить естественные процессы концентрации производств. Перспективные кластеры начнут испытывать дефицит ресурсов, которые будут направляться на поддержку «социально значимых» квази-кластеров с туманным будущим.

\section{Доминирование групп спеизильных интересов}

Из-за информационной асимметрии акторы лучше осведомлены о своей эффективности, реальной инновационной активности и перспективах развития технологий, чем власти, ответственные за кластерную политику. Поэтому существует вероятность, что далеко не самые перспективные игроки за счет лоббирования сумеют «перетянуть» на себя господдержку.

\section{Уровень разнообразия 8 кластере и регионе}

Возникновение подобных рисков - обратная сторона повышения внешней экономии предприятий за счет максимальной концентрации. В большинстве случаев высокий уровень концентрации (и территориальной неравномерности распределения) видов экономической деятельности приводит к росту внешней экономии и производительности. Как известно, вследствие усиления специализации территорий возрастает риск того, что в силу разных причин она окажется невостребованной. Чрезмерная специализация приводит к снижению разнообразия (технологий, видов деятельности, организаций, моделей ведения бизнеса, культуры и пр.), фиксации на определенной технологической траектории, потере темпов инновационного развития, снижению конкурентоспособности кластера и уровня благосостояния региона. Излишняя концентрация способна вызвать потерю кадров, так как объективно не все люди могут реализоваться при отсутствии альтернативных видов деятельности. Яркий пример территорий, попавших в ловушку специализации, - российские моногорода, построенные вокруг градообразующих предприятий ${ }^{16}$. Поэтому целесообразно обеспечить определенное разнообразие направлений, по которым государство стимулирует развитие кластеров.

\footnotetext{
${ }^{13}$ Разные типы внешней экономии, в принципе, интериоризируются неодинаково. Легче всего компаниям достаются преимущества от повышения эффективности производственного процесса. Например, экономия на транспортных затратах, возникающая при совместной локализации с поставщиками, автоматически трансформируется в выгоды производителей. Вместе с тем столь же легко интериоризируются и отрицательные внешние эффекты подобного типа: повышение стоимости аренды или оплаты труда неизбежно ведет к росту издержек фирм. Институциональные и инновационные преимущества, несмотря на желание предприятий, превращаются из внешней экономии во внутреннюю гораздо сложнее. В частности, самоорганизация для реализации (институциональное преимущество) зависит от коммуникативных навыков и авторитетности инициатора, что напрямую определяет размер государственных преференций и приобретение инновационных преимуществ.

14 По мнению экспертов Совета по изучению производительных сил (СОПС), «различие мер экономической поддержки отчасти связано с тем, что экономическое стимулирование как таковое для кластерной политики не характерно. Подобные меры, носящие налоговый, таможенный или бюджетный характер, в большей степени отражают суть промышленной политики. В свою очередь, кластерная политика опирается на развитие коммуникаций, обмен опытом и расширение сетевого взаимодействия участников, что предполагает не столько их экономическую поддержку и связанную с этим нормотворческую работу, сколько принятие организационных мер» [СОПС, 2009].

15 Другая крайность — нежелательная и рискованная — моноспециализация территории.

${ }^{16}$ Об этом предупреждал еще А. Маршалл: «Район, жизнь которого зависит преимущественно от одной отрасли производства, обречен на глубокую депрессию в случае падения спроса на ее продукцию или сокращения поставок используемого сырья. Подобная ситуация менее характерна для крупных городов или индустриальных районов, где развиваются несколько самостоятельных отраслей. Если одна из них временно потерпит неудачу, другие окажут ей косвенную индустриальных районов, где развиваются несколько самостоятельных отраслей. Если одна из них временно потерпит неудачу, другие окажут ей косве
поддержку, причем дадут возможность местным лавочникам продолжать снабжение рабочих отрасли, попавшей в трудное положение» [Marshall, 1920].
} 
Кластерная стратегия, кроме того должна органично дополняться мерами по развитию агломераций (пространств, концентрирующих различную деятельность $)^{17}$. Следует, однако, учитывать, что положительные внешние эффекты, с одной стороны, и агломерации, с другой, могут по-разному влиять на динамику различных секторов. Одни компании более чувствительны к кластерной модели, другие выигрывают вследствие урбанизационных тенденций. Существует предположение, что эффект урбанизации более предпочтителен для новых высокотехнологичных видов деятельности, развитие которых требует диверсифицированной городской среды. По мере «взросления» отрасли знания в ней формализуются, технологии стандартизируются, а зависимость от новых идей ослабевает. «Цена» расположения в городе становится неоправданной; возрастает значение эффекта кластеризации. Вследствие этого предприятия в зрелых секторах перемещаются в меньшие по размеру города с узкой специализацией [Duranton, Puga, 2001; Neffke et al., 2008]. Предварительные результаты исследований российских регионов, полученные нами, подтверждают данную гипотезу лишь частично ${ }^{18}$.

Действительно, высокотехнологичные сектора (биофармацевтика, ИКТ, аэрокосмическая промышленность и пр.) тяготеют к регионам, аккумулирующим многие другие виды деятельности. Напротив, на расположение традиционных производств (металлургия, тяжелое машиностроение, автомобильная промышленность и пр.) эффект урбанизации не оказывает существенного влияния. Тем не менее они также подвергаются эффекту кластеризации, стремясь дислоцироваться в тех регионах, где представлены сопряженные виды деятельности. Таким образом, хотя эффекты кластеризации и урбанизации имеют разную природу, на практике они не противоречат, а дополняют друг друга.

По нашей оценке, развитие кластеров и агломераций оказывает самостоятельный положительный эффект на инновационную активность регионов, влияя на разные компоненты этого феномена [Куценко, Тюмениева, 2011].

Ослабление или разрушение кластеров в результате изменений политического контекста

К подобным изменениям относятся: трансформация государственных границ, перераспределение расклада сил между региональными и федеральными властями, присоединение к ВТО, экономическим союзам и пр.
В Советском Союзе размещение производительных сил планировалось исходя из тогдашнего географического охвата. После его распада с точки зрения новых суверенных государств оно уже не могло считаться оптимальным. Зачастую предприятия, связанные производственными цепочками, оказывались в различных налоговых, административных и прочих условиях, что сильно затрудняло сотрудничество. Ослабление федеральной власти России в 1990-е гг. привело к фрагментации внутреннего рынка; каждый регион стал предоставлять преференции своим производителям, усложняя условия для «внешних». Местные власти не сумели сформировать собственные конкурентоспособные в глобальном контексте кластеры. Включение страны в международные экономические альянсы расширяет возможности для развития таких образований. В то же время оно несет с собой серьезные риски, не только негативно сказываясь на перспективах отдельных кластеров, но и сталкивая их с интересами сильных зарубежных игроков ${ }^{19}$.

По сути, рассмотренные провалы государства относятся не столько к кластерам, сколько к политике в целом, так как подобные решения принимаются самыми высокими инстанциями.

\section{Отсутствие межведомственной координации}

Для успешного развития кластеров важна согласованная работа управляющих структур различного уровня. Однако на практике возможно несовпадение интересов сторон (государственной власти, бизнеса, научного сообщества). Более того, они могут формировать «свои» кластеры и игнорировать «чужие». В результате подобной несогласованности кластеры получают недостаточно комплексную поддержку, что затрудняет достижение поставленных целей и ведет к нерациональному расходованию средств.

\section{Заключение}

Эффективная кластерная политика предполагает соблюдение баланса в развитии кластеров, при котором избегаются в равной степени критичные ловушки провалов рынка и государства. Недостаточно делать ставку на кластерный подход, полагая, что сам по себе он станет залогом успеха экономической политики. При определенном раскладе вместо положительного эффекта неудавшаяся кластерная политика лишь усилит провалы рынка за счет столь же болезненных провалов государства.

Обоснованная политика предполагает, прежде всего, идентификацию специфических для каждого

\footnotetext{
${ }^{17}$ Принципиальное отличие кластеров от агломераций (городов) состоит в том, что для последних наличие связи между аккумулированными видами деятельПринципиальное отличие кластеров от агломераций (городов) состоит в том, что для последних наличие связи между аккумулированными видами деятель-
ности не является обязательным условием. Как и кластер, агломерация порождает ряд внешних экономий, но другого типа. Среди преимуществ урбанизации, ности не является обязательным условием. Как и кластер, агломерация порождает ряд внешних экономий, но другого типа. Среди преимуществ урбанизации,
как правило, выделяют развитую городскую инфраструктуру; относительно большой рыночный потенциал, формируемый различными компаниями; непосредственную близость научных и образовательных учреждений. Классическим эффектом урбанизации являются инновационные преимущества, связанные с перекрестной диффузией инноваций, когда множество различных видов деятельности формируют необходимый уровень разнообразия.

18 Заметим, что попытки зарубежных исследователей эмпирически проверить эту гипотезу также привели к неоднозначным результатам. Так, множество стандартизированных видов промышленной деятельности (металлургия, текстильная, автомобильная, лесоперерабатывающая отрасли) располагаются неравнодартизированных видов промышленной деятельности (металлургия, текстильная, автомобильная, лесоперерабатывающая отрасли) располагаются неравномерно, тяготея к небольшим специализированным городам [Black, Henderson, 2003]. Напротив, производство дизайнерской одежды, издательская и полигра-
фическая деятельность, финансовые и бизнес-услуги, исследования и разработки характерны преимущественно для больших городов [Коlko, 1999]. Работа фическая деятельность, финансовые и бизнес-услуги, исследования и разработки характерны преимущественно для больших городов [Коlko, 1999]. Работа
В. Хендерсона и его коллег [Henderson et al., 1995] в целом подтвердила значимые положительные эффекты кластеризации для зрелых отраслей, а также преимущества кластеризации и урбанизации для новых секторов. С другой стороны, более позднее исследование В. Хендерсона [Неnderson, 2003] привело к иным выводам: эффекты локализации оказались значимыми для высокотехнологичных отраслей, а эффекты урбанизации - для отраслей, связанных с машиностроением.

19 Продолжающаяся интеграция европейских стран расширяет границы относительно однородного экономического пространства, на котором предприятия размещают производства, исходя из существующих кластерных эффектов. Европейские кластеры усиливают свои позиции за счет территорий с менее значимыми центростремительными эффектами.
} 
конкретного кластера провалов рынка - системных проблем локального сообщества, которые не сводятся к уникальным потребностям его участников (бизнеса, науки, организаций инфраструктуры, власти) и могут быть решены только совместными усилиями. Помимо этого необходимость преодоления рисков провала государства приводит к формулированию ряда основополагающих принципов кластерной политики. Среди них - интеграция кластерного подхода в инновационные программы; идентификация и обоснование ключевых точек роста региональных экономик; всевозможные виды поддержки бизнеса; прозрачный конкурсный отбор заявок на создание кластеров; обеспечение соответствия мер госрегулирования потребностям конкретных кластеров; комплексное долгосрочное содействие отобранным кластерам; мониторинг политики.

Если перечисленные требования не выдерживаются, специфика кластерной политики начинает размываться, сливаясь с другими мерами, ее эффективность падает и сама необходимость такого инструмента инновационной политики обоснованно ставится под сомнение.

Абашкин В.Л., Бояров А.Д., Куценко Е.С. (2012) Кластерная политика в России: от теории к практике // Форсайт. Т. 6. № 3. С. 16-27.

Гнедовский М. (2005) Творческие индустрии: политический вызов для России // Отечественные записки. № 4 (24). http://www.strana-oz. ru/?numid=25\&article=1106 (дата доступа 15 июня 2012 г.).

Дероше П. (2011) Возможна ли новая Кремниевая долина? Публичная лекция на Полит.py. http://www.polit.ru/lectures/2011/04/08/ deroche.html (дата доступа 25 августа 2012 г.).

Коуз Р. (1993) Проблема социальных издержек // Фирма, рынок и право. М.: Дело ЛТД. С. 87-141.

Кулишер И.М. (2004) История экономического быта Западной Европы. 9-е изд. Т. 1. Челябинск: Социум.

Куценко Е.С. (2012) Зависимость от предшествующего развития в сфере пространственного размещения производительных сил плохая новость для эмпирических исследований агломерационных эффектов // Журнал Новой экономической ассоциации. № 2 (14) C. $10-26$.

Куценко Е.С., Тюменцева Д.С. (2011) Кластеры и инновации в субъектах РФ: результаты эмпирического исследования // Вопросы экономики. № 9. С. 93-107.

Латов Ю.В. (2005) Мы живем не в лучшем из миров! (Популярное изложение QWERTY-номики и исследований Path Dependence) // 20 лет исследования QWERTY-эффектов и зависимости от предшествующего развития. http://ecsocman.edu.ru/text/16213114/ (дата доступа 17 марта 2012 г.).

Райзберг Б.А., Лозовский Л.Ш., Стародубцева Е.Б. (1999) Современный экономический словарь (2-е изд., испр.). М.: ИНФРА-М. Скоробогатов А.С. (2006) Институциональная экономика. Курс лекций. СПб.: ГУ-ВШЭ.

СОПС (2009) Разработка методических рекомендаций по развитию территориальных кластеров в субъектах Российской Федерации. Отчет о научно-исследовательской работе (шифр П315-19-09, № государственной регистрации 01200952406). М.: СОПС.

Arthur W. B. (1994) Increasing Returns and Path Dependence in the Economy. Ann Arbor: University of Michigan Press.

Black D., Henderson J.V. (2003). Urban Evolution in the US // Journal of Economic Geography. Vol. 3ю № 4. Р. 343-372.

David P.A. (1985) Clio and the Economics of QWERTY // American Economic Review. Vol. 75. № 2. P. 332-337.

Duranton G. (2011) California Dreamin’: The Feeble Case for Cluster Policies // Review of Economic Analysis. № 3. P. 3-45.

Duranton G., Puga D. (2001) Nursery Cities // American Economic Review. Vol. 91. P. 1454-1477.

Duranton G., Puga D. (2004) Microfoundations of urban agglomeration economies // Henderson V., Thisse J.-F. (eds.) Handbook of Regional and Urban Economics. Vol. 4. Amsterdam: North Holland. P. 2063-2117.

Henderson V. (2003) Marshall's Scale Economies // Journal of Urban Economy. Vol. 53. P. 1-28.

Henderson V., Kuncoro A., Turner M. (1995) Industrial Development in Cities // Journal of Political Economy. Vol. 103 (5). P. $1067-1090$.

Jaruzelski B., Dehoff K. (2007) The Consumer Connection: The Global Innovation 1000 (Strategy+Business Resilience Report). Booz Allen Hamilton. http://www.strategy-business.com/media/file/resilience-12-10-07.pdf (accessed 15 August 2012).

Ketels C. (2003) The Development of the Cluster Concept - Present Experiences and Further Developments. Paper presented at the NRW Conference on Clusters, 5-th December, Duisburg, Germany. http://www.isc.hbs.edu/pdf/Frontiers_of_Cluster_Research_2003.11.23.pdf (accessed 17 July 2012).

Kolko J. (1999) Can I Get Some Service Here? Information Technology, Service Industries, and Future Cities (mimeo). Harvard University.

Margolis S.E., Liebowitz S.J. (1998) Path Dependence // Newman P. (ed.) The New Palgrave Dictionary of Economics and Law. London: Macmillan.

Marshall A. (1920) Principles of Economics (8-th ed). London: Macmillan and Co.

Martin P., Mayer T., Mayneris F. (2008) Spatial concentration and firm-level productivity in France (discussion paper № 6858). CEPR.

Martin P., Mayer T., Mayneris F. (2010) Public Support to Clusters: A Firm Level Study of French "Local Productive Systems" (mimeo). University of Paris I. http://perso.uclouvain.be/florian.mayneris/rsue.pdf (accessed 31 May 2012).

Menzel M.-P., Fornahl D. (2007) Cluster Life Cycles - Dimensions and Rationales of Cluster Development // Jena Economic Research Papers. http://papers.ssrn.com (accessed 29 June 2012).

Neffke F., Henning S.M., Boschma R., Lundquist K.-J., Olander L.-O. (2008). Who Needs Agglomeration? Varying Agglomeration Externalities and the Industry Life Cycle (Working Paper). Utrecht University.

Porter M. (2000) Location, Competition and Economic Development: Local Clusters in a Global Economy // Economic Development Quarterly. vol. 14. № 1. P. 15-34.

Richter R., Streb J. (2011) Catching-Up and Falling Behind - Knowledge Spillover from American to German Machine Tool Makers // The Journal of Economic History. Vol. 71. № 4. P. 1006-1031.

Rigby D.L., Essletzbichler A. (2006) Technological variety, technological change and a geography of production techniques // Journal of Economic Geography. № 6. P. 45-70.

van der Linde C. (2003) The Demography of Clusters - Findings from the Cluster Metastudy // Bröcker J., Dohse D., Soltwedel R. (eds.) Innovation Clusters and Interregional Competition. Berlin: Springer Verlag. P. 130-149.

Vorobyev P.V., Kislyak N.V., Davidson N.B. (2010) Spatial concentration and firm performance in Russia. Kiev: EERC. 


\title{
A Rational Cluster Strategy: Manoeuvring between Market and Government Failures
}

\section{Evgeniy Kutsenko}

Senior Research Fellow, Institute for Statistical Studies and Economics of Knowledge, National Research University Higher School of Economics. Address: National Research University Higher School of Economics, 20, Myasnitskaya str., Moscow, 101000.

E-mail: ekutsenko@hse.ru

\begin{abstract}
$\mathrm{D}$ ebates on the viability - and the extent of public intervention-that are requisite in the formation and development of clusters are ongoing. It seems, on one hand, that there are few cases of systematic and successful cluster creation from the ground up. On another, clusters shaped without any contribution from government are difficult to find. In this sense, the empirical evidence will not readily provide an answer to the questions, how much intervention is needed and are the existing tools adequate for creating clusters.

The author analyses two basic types of market failures related to shaping and development of clusters. These are

a mismatch of territorial location of production forces to existing centrifugal and centripetal agglomeration effects (positive and negative external gains, as well as underproduction of a positive external gain that influences performance of local actors).

The paper also concerns possible causes, where public cluster policy produces inefficiencies (government failures). That is, it analyses the most obvious risks for policy implementation. It is argued that an efficient policy should be aimed at dealing with market failures, while the procedures and implementing algorithms - at overcoming government failures.
\end{abstract}

\section{Keywords}

cluster policy; market failures; government failures; location of productive forces.

\section{References}

Abashkin V., Boyarov A., Kutsenko E. (2012) Klasternaya politika v Rossii: ot teorii k praktike [Cluster Policy in Russia: From Theory to Practice]. ForesightRussia, vol. 6, no 3, pp. 16-27.

Arthur W.B. (1994) Increasing Returns and Path Dependence in the Economy, Ann Arbor: University of Michigan Press.

Black D., Henderson J.V. (2003). Urban Evolution in the US. Journal of Economic Geography, vol. 3, no 4, pp. 343-372.

David P.A. (1985) Clio and the Economics of QWERTY. American Economic Review, vol. 75, no 2, pp. 332-337.

Desrochers P. (2011) Vozmozhna li novaya Kremnievaya dolina? Publichnaya lektsiya na Polit.ru [Is It Possible to Replicate Silicon Valley?]. Available at: http:// www.polit.ru/lectures/2011/04/08/deroche.html (accessed 25 August 2012).

Duranton G. (2011) California Dreamin': The Feeble Case for Cluster Policies. Review of Economic Analysis, no 3, pp. 3-45.

Duranton G., Puga D. (2001) Nursery Cities. American Economic Review, vol. 91, pp. 1454-1477.

Duranton G., Puga D. (2004) Microfoundations of Urban Agglomeration Economies. Handbook of Regional and Urban Economics (eds. V. Henderson,

J.-F. Thisse), vol. 4, Amsterdam: North Holland, pp. 2063-2117.

Gnedovskii M. (2005) Tvorcheskie industrii: Politicheskii vyzov dlya Rossii [Creative Industries: Political Challenge for Russia]. Otechestvennye Zapiski, no 4

(24). Available at: http://www.strana-oz.ru/?numid=258article=1106 (accessed 15 June 2012)

Henderson V. (2003) Marshall's Scale Economies. Journal of Urban Economy, vol. 53, pp. 1-28.

Henderson V., Kuncoro A., Turner M. (1995) Industrial Development in Cities. Journal of Political Economy, vol. 103 (5), pp. 1067-1090.

Jaruzelski B., Dehoff K. (2007) The Consumer Connection: The Global Innovation 1000 (Strategy+Business Resilience Report), Booz Allen Hamilton. Available at: http://www.strategy-business.com/media/file/resilience-12-10-07.pdf (accessed 15 August 2012).

Ketels C. (2003) The Development of the Cluster Concept - Present Experiences and Further Developments. Paper presented at the NRW Conference on Clusters, 5-th December, Duisburg, Germany. Available at: http://www.isc.hbs.edu/pdf/Frontiers_of_Cluster_Research_2003.11.23.pdf (accessed 17 July 2012).

Kolko J. (1999) Can I Get Some Service Here? Information Technology, Service Industries, and Future Cities (mimeo), Harvard University.

Kouz R. (1993) Problema sotsialnykh izderzhek [The Problem of Social Costs]. Firma, rynok i pravo [Firm, Market and Law], Moscow: Delo LTD, pp. 87-141.

Kulisher I. (2004) Istoriya ekonomicheskogo byta Zapadnoi Evropy [The History of Economic Life of Western Europe] (9-th ed), vol. 1, Chelyabinsk: Sotsium.

Kutsenko E. (2012) Zavisimost' ot predshestvuyushchego razvitiya v sfere prostranstvennogo razmeshcheniya proizvoditel'nykh sil - plokhaya novost' dlya empiricheskikh issledovanii aglomeratsionnykh effektov [Path-dependence in Spatial Distribution of Productive Forces - Bad News for Empirical Studies of Agglomeration Effects]. Zhurnal Novoi ekonomicheskoi assotsiatsii, no 2 (14), pp. 10-26.

Kutsenko E., Tyumentseva D. (2011) Klastery i innovatsii v sub"ektakh RF: rezul'taty empiricheskogo issledovaniya [Clusters and Innovation in the Russian Regions: Results of an Empirical Study]. Voprosy ekonomiki, no 9, pp. 93-107.

Latov Yu.V. (2005) My zhivem ne v luchshem iz mirov! (populyarnoe izlozhenie QWERTY-nomiki i issledovanii Path Dependence) [We are not Living in the Best World (A Popular Interpretation of QWERTY-economics and Path Dependence]. 20 let issledovaniya QWERTY-effektov i zavisimosti ot predshestvuyushchego razvitiya [20 Years of Studying QWERTY Effects and Path Dependence]. Available at: http://ecsocman.edu.ru/text/16213114/ (accessed 17 March 2012).

Margolis S., Liebowitz S. (1998) Path Dependence. The New Palgrave Dictionary of Economics and Law (ed. P. Newman), London: Macmillan.

Marshall A. (1920) Principles of Economics (8-th ed), London: Macmillan and Co.

Martin P., Mayer T., Mayneris F. (2008) Spatial concentration and firm-level productivity in France (discussion paper № 6858), CEPR.

Martin P., Mayer T., Mayneris F. (2010) Public Support to Clusters: A Firm Level Study of French "Local Productive Systems" (mimeo), University of Paris I.

Available at: http://perso.uclouvain.be/florian.mayneris/rsue.pdf (accessed 31 May 2012).

Menzel M.-P., Fornahl D. (2007) Cluster Life Cycles - Dimensions and Rationales of Cluster Development. Jena Economic Research Papers. Available at: http:// papers.ssrn.com (accessed 29 June 2012).

Neffke F., Henning S.M., Boschma R., Lundquist K.-J., Olander L.-O. (2008). Who Needs Agglomeration? Varying Agglomeration Externalities and the Industry Life Cycle (Working Paper), Utrecht University.

Porter M. (2000) Location, Competition, and Economic Development: Local Clusters in a Global Economy Economic Development Quarterly, vol. 14, no 1, pp. 15-34. Raizberg B., Lozovskii L., Starodubtseva E. (1999) Sovremennyi ekonomicheskii slovar' [The Modern Economic Dictionary] (2-nd ed., rev.), Moscow: INFRA-M. Richter R., Streb J. (2011) Catching-Up and Falling Behind - Knowledge Spillover from American to German Machine Tool Makers. The Journal of Economic History, vol. 71, no 4, pp. 1006-1031.

Rigby D.L., Essletzbichler A. (2006) Technological variety, technological change and a geography of production techniques. Journal of Economic Geography, no 6,

pp. 45-70.
Skorobogatov A. (2006) Institutsional'naya ekonomika. Kurs lektsii [Institutional Economy. Course of Lectures], Saint-Petersburgh: HSE.

SOPS (2009) Razrabotka metodicheskikh rekomendatsii po razvitiyu territorial'nykh klasterov v sub"ektakh Rossiiskoi Federatsii. Otchet o nauchno-issledovatel'skoi rabote (shifr P315-19-09, № gosudarstvennoi registratsii 01200952406) [Developing Methodical Recommendations on Developing Territorial Clusters in the Russian Regions. Research report (chiffre P315-19-09, registration number 01200952406], Moscow: SOPS.

van der Linde C. (2003) The Demography of Clusters - Findings from the Cluster Metastudy. Innovation Clusters and Interregional Competition (eds. J. Bröcker, D. Dohse, R. Soltwedel), Berlin: Springer Verlag, pp. 130-149.

Vorobyev P.V., Kislyak N.V., Davidson N.B. (2010) Spatial Concentration and Firm Performance in Russia, Kiev: EERC. 


\title{
Кластерная политика в России: от теории к практике
}

\author{
В.Л. Абашкин ${ }^{*}$ А.Д. Бояров * , Е.С. Куценко * *
}

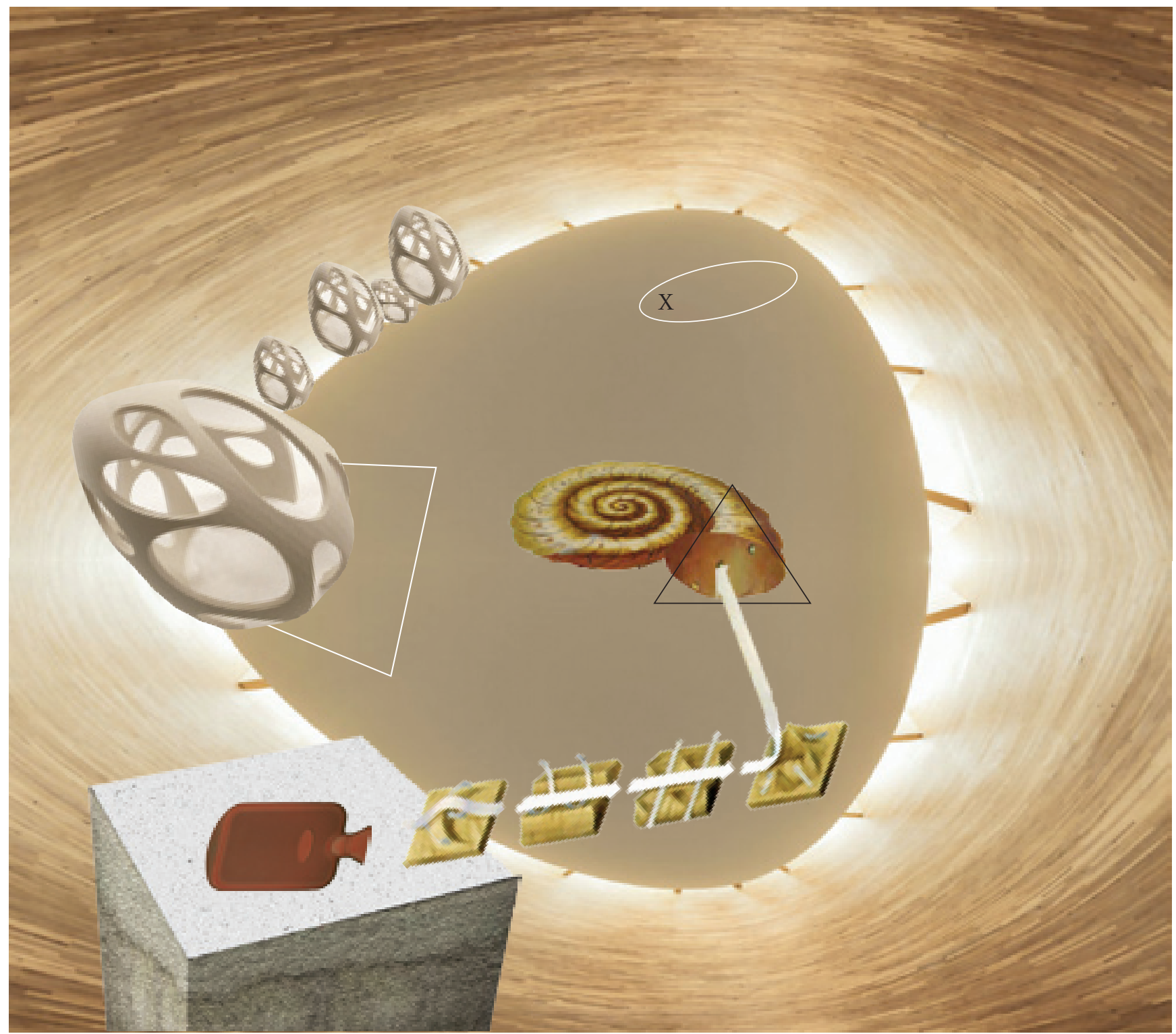

Активное развитие производственных кластеров во многих странах обусловлено широкими возможностями для экономического роста и положительными мультипликационными эффектами. В международной практике формирование кластерной стратегии рассматривается как важнейшая составляющая инновационной политики, демонстрирующая взвешенный долгосрочный подход государства к комплексному освоению территорий.

Сопоставляя лучший зарубежный и отечественный опыт, авторы выявляют и обосновывают ключевые факторы успеха кластерной политики в России.
* Абашкин Василий Львович - старший научный сотрудник, Центр научно-технической, инновационной и информационной политики. E-mail: vabashkin@hse.ru

** Бояров Артур Дмитриевич - старший научный сотрудник, отдел частно-государственного партнерства в инновационной сфере. E-mail: boyarov@hse.ru

*** Куценко Евгений Сергеевич - старший научный сотрудник, Центр научно-технической, инновационной и информационной политики. E-mail: ekutsenko@hse.ru

Институт статистических исследований и экономики знаний НИУ ВШЭ

Адрес: Национальный исследовательский университет «Высшая школа экономики», 101000, Москва, Мясницкая ул., 20.

\section{Ключевые слова}

кластер; кластерная политика; инновационная политика; государственные программы; взаимодействие стейкхолдеров; инновационное развитие. 
K онкурентоспособность компаний во многом зависит не только от внутренних ресурсов, качества управления, макроэкономических и институциональных факторов, определяемых на национальном уровне, но и от непосредственного окружения: поставщиков, инфраструктуры, вузов, исследовательских организаций, партнеров. Эти факторы обрели особую актуальность в связи с поиском источников повышения инновационной активности бизнеса. Регулярное производство востребованных рынком инноваций возможно лишь в соответствующей среде функционирования. Поэтому, несмотря на интенсивное развитие глобализации, географическое распределение инновационно-активных компаний остается крайне неравномерным.

Широкое распространение в качестве инструмента развития инноваций на региональном уровне получили кластеры. Они направлены на консолидацию усилий «местных» игроков (бизнеса, науки, образования, деловых ассоциаций и т. п.) в разработке и реализации совместных проектов, содействующих укреплению их рыночных позиций. Поставляя на глобальный рынок конкурентоспособную продукцию, кластеры становятся точками роста, оказывая влияние как на экономику региона, так и страны в целом.

В силу сказанного, кластерная политика становится все более востребованным инструментом развития. Соответствующие программы реализуются в 26 стра нах Европейского Союза $(\mathrm{EC})^{1}$, причем в двух третях случаев они интегрированы в инструментарий инновационной политики [Oxford Research, 2008].

В России с конца 2000-х гг. осуществляются инициативы «новой волны», включая разработку программ инновационного развития компаний с госучасти ем; формирование национальных технологических платформ; поддержку кооперации компаний и вузов по созданию высокотехнологичных производств и др. К их числу относится и развитие региональных кластеров. Заимствуя зарубежный опыт, необходимо учитывать национальный контекст, что позволит вы явить слабые места и адаптировать соответствующие элементы политики.

Сопоставив международную и отечественную практику, попытаемся идентифицировать ключевые факторы успеха кластерных стратегий.

\section{Европейский опыт}

В ряде европейских стран аккумулирован солидный опыт реализации инновационной политики. Специальные программы предусматривают инстру менты как прямого, так и косвенного стимулиро вания инновационной деятельности фирм. К числу прямых механизмов относятся снижение стоимости капитала, вкладываемого в инновационное развитие (субсидирование, льготное налогообложение ИиР); развитие венчурного капитала и фондовых рынков. Примерами косвенных мер служат поощрение сотрудничества университетов и компаний, межфирменной кооперации; совершенствование систем защиты прав
Территориальные кластеры объединяют научные и образовательные учреждения, инвесторов, некоммерческие и общественные организации, органы государственной власти и местного самоуправления. Кластерные принципы организации хозяйственной деятельности присущи таким территориальным образованиям, как особые экономические зоны, наукограды, технопарки, бизнесинкубаторы, центры трансфера технологий, коллективного пользования научным оборудованием и др. Выполняя функцию катализатора кооперационных связей и усиливая географическую локализацию научно-производственного потенциала регионов страны, они служат инструментами кластерной политики в России.

интеллектуальной собственности, антимонопольного регулирования и подготовки кадров; формирование служб управленческого консультирования; увеличение мобильности рабочей силы; создание научнотехнической инфраструктуры.

В последние десятилетия в развитых странах наблюдается смещение акцента в сторону мер косвенного стимулирования инноваций. Если в 1970-80-х гг. поддержка последних носила «технологический» фокус, то сегодня пристальное внимание уделяется кластерным стратегиям, направленным на создание кооперативных и знаниевых сетей, территориальных зон развития.

Ретроспективный анализ позволяет выделить три «поколения» инновационной политики [European Commission, 2002]. Первое поколение ориентировалось на линейную модель создания инноваций — от научной идеи через стадию прикладных исследований и разработок (ИиР) до коммерческого продукта, востребованного рынком. Второе исходило из комплексной природы инноваций, многообразия источников новаторских идей и направлений коммерциализации, включая инфраструктурную поддержку. Новейшее, третье поколение предполагает эффективную координацию различных сегментов политики, определяющих характер инновационных процессов в экономике (промышленной, правовой, антимонопольной и т. д.). Его основной фокус — на развитии образования, взращивании лидеров, расширении сетевой кооперации (табл. 1). Кластеры как инструмент, направленный на усиление сотрудничества и укрепление горизонтальных связей, в полной мере могут быть отнесены к политике третьего поколения.

Кластерный подход в развитых странах внедрялся поэтапно, начиная с обеспечения необходимого уровня финансирования венчурной отрасли, прямого стимулирования, достижения эффективного взаимодействия науки и бизнеса, формирования основных элементов инновационной инфраструктуры. С 1990-х гг. стали активно развиваться специализированные центры по кооперации университетов

Программы поддержки кластеров служат механизмом реализации кластерной политики. На общем уровне определяются стратегические приоритеты, цели, набор возможных инструментов развития кластеров. В программах прописываются алгоритмы, сценарии, условия поддержки, ресурсное обеспечение мер политики и ответственные за их реализацию [Oxford Research, 2008]. 


\section{Табл. 1. Соотнесение трех поколений инновационной политики}

\begin{tabular}{|c|c|c|}
\hline Доминанта & $\begin{array}{c}\text { Инновационная политика } \\
\text { сфокусирована на отдельных } \\
\text { секторах экономики }\end{array}$ & $\begin{array}{c}\text { Инновационная политика не } \\
\text { сфокусирована на отдельных } \\
\text { секторах экономики }\end{array}$ \\
\hline $\begin{array}{l}\text { Инновационная политика } \\
\text { ориентирована на определенные цели } \\
\text { (экономический рост) }\end{array}$ & $\begin{array}{l}\text { Первое поколение - традиционная } \\
\text { научно-техническая политика } \\
\text { (линейная модель) }\end{array}$ & $\begin{array}{l}\text { Второе поколение - интегрированная } \\
\text { инновационная политика }\end{array}$ \\
\hline $\begin{array}{l}\text { Многоцелевая инновационная политика } \\
\text { (устойчивый экономический рост, } \\
\text { качество жизни населения) }\end{array}$ & $\begin{array}{l}\text { Инновации в определенных } \\
\text { секторах }\end{array}$ & $\begin{array}{l}\text { Третье поколение — горизонтальная } \\
\text { инновационная политика }\end{array}$ \\
\hline
\end{tabular}

и промышленности, междисциплинарным исследованиям, трансферу технологий; научные парки; региональные центры коммерциализации.

Международные исследования свидетельствуют об относительной «молодости» кластерных проектов даже в развитых государствах лишь чуть более четверти из них были запущены до 1999 г. В развивающихся и особенно транзитивных странах доля таких ранних инициатив существенно меньше (рис. 1). Кроме того, выявлено, что на первой стадии развития кластера большое значение имеет государственная поддержка, причем не только организационная, консультационная и пр., но и финансовая. Опрос участников более двухсот кластерных инициатив по всему миру [Sölvell et al., 2003] выявил, что большинство из них финансируется государством, однако организационная роль последнего выражена слабее (рис. 2).

В связи с этим в ЕС стали набирать популярность государственные программы поддержки кластеров.

\section{Рис. 1. Распределение кластерных инициатив} в развитых, развивающихся и транзитивных странах по срокам возникновения (\%)

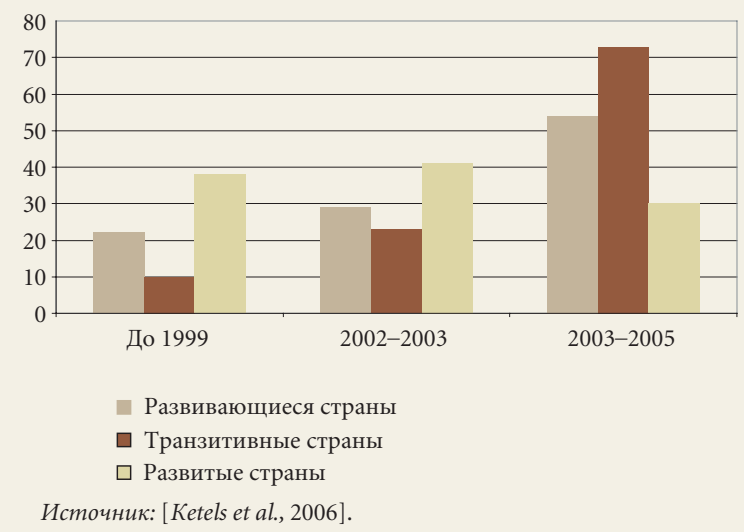

Около половины европейских стран начали осущест влять их после 2000 г. (рис. 3). Вместе с тем отдельные регионы применяли кластерный подход и ранее. Так, Бавария, Баден-Вюртемберг и Северный РейнВестфалия в Германии предпринимали подобные инициативы еще в 1980-е гг., задолго до появления федеральных программ [Oxford Research, 2008].

Наиболее успешными программами развития кластеров, ставшими модельными для многих европейских аналогов, считаются BioRegio и InnoRegio (Германия), а также Competitiveness Clusters (Франция).

Программа BioRegio способствовала четырехкратному увеличению числа компаний и созданию более 9000 рабочих мест в секторе биотехнологий, что позволило существенно сократить разрыв с традиционным лидером - Великобританией. Регионы, участвовавшие в программе, продемонстрировали более заметные успехи по сравнению с другими федеральными землями (рис. 4). Сегодня Германия рассматривается в качестве европейского лидера в области биотехнологий: на ее территории локализованы примерно 500 предприятий. Их оборот оценен в размере 2.19 млрд долл. (темп прироста - 30\% за период 2005-2008 гг.), а численность занятых составила 14.5 тыс. чел. [Research in Germany, 2011].

В рамках программы InnoRegio были отобраны 23 кластера из 444 подавших заявки. Из тех, чьи заявки были отклонены, 40\% кластеров позднее все же реализовали свои проекты. Среди таких кластеров 61\% получили государственное финансирование по другим программам, а 39\% оно не понадобилось [Eickelpasch, Fritsch, 2005]. С 2000 по 2004 г. численность занятых в компаниях - участниках программы InnoRegio выросла на 11\%. Чуть менее половины из них (44\%) смогли подать заявки на патент, а 40\% - даже выпустить новые продукты [BMBF, 2006].

\section{Рис. 2. Инициирование и финансирование кластерных потоков в развитых странах} (\% от общего числа кластерных проектов)

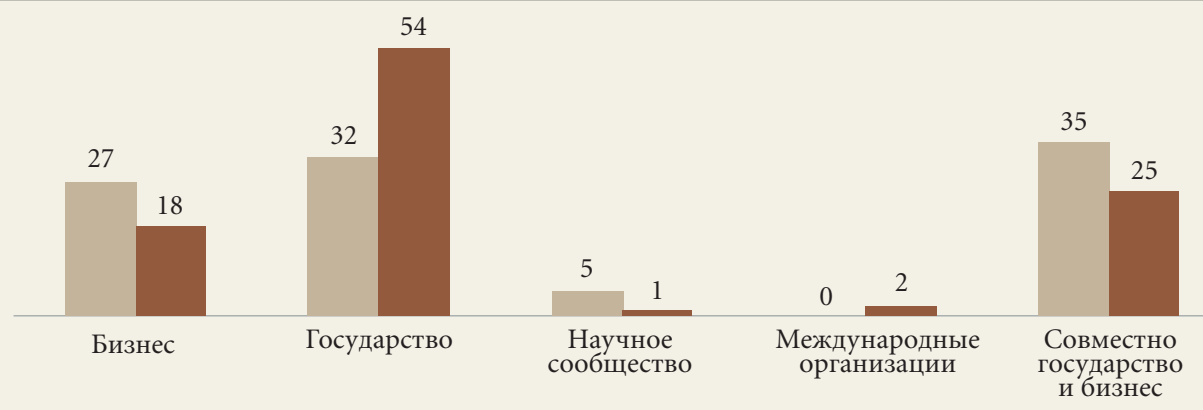

— Инициирование

口 Финансирование 
Рис. 3. Распределение кластерных программ в странах EC по срокам возникновения

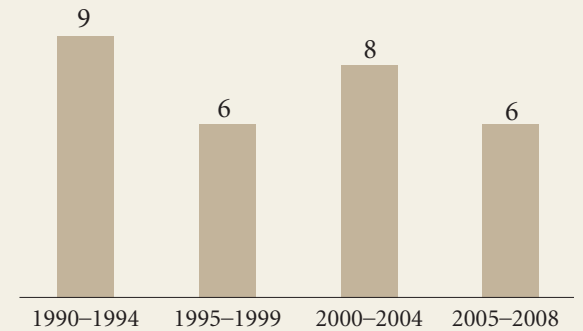

Источник: [Oxford Research, 2008].

$\mathrm{y}_{\text {спех }}$ BioRegio и InnoRegio привел к появлению целого ряда федеральных программ поддержки кластеров в Германии (табл. 2).

Французская программа Competitiveness Clusters в отличие от германских характеризуется солидным бюджетом и большим числом поддерживаемых кластеров. На нее изначально планировалось выделить 750 млн евро и распределить их по 10-15 кластерам мирового уровня (соответственно, каждый из них получил бы в среднем от 16.7 до 25 млн евро на три года). Однако число поданных заявок - $105-$ превзошло ожидания, и бюджет решили удвоить до 1.5 млрд евро, а круг поддерживаемых кластеров расширился до 71 [Pro Inno Europe, 2009; OECD, 2007]. Из них были выделены семь кластеров мирового уровня (global competitiveness clusters), 10 - потенциально мирового уровня (globally-oriented competitiveness clusters) и 54 - «обычных» (competitiveness clusters).
Рис. 4. Рост числа биотехнологических компаний в регионах - победителях конкурса BioRegio и в других регионах Германии

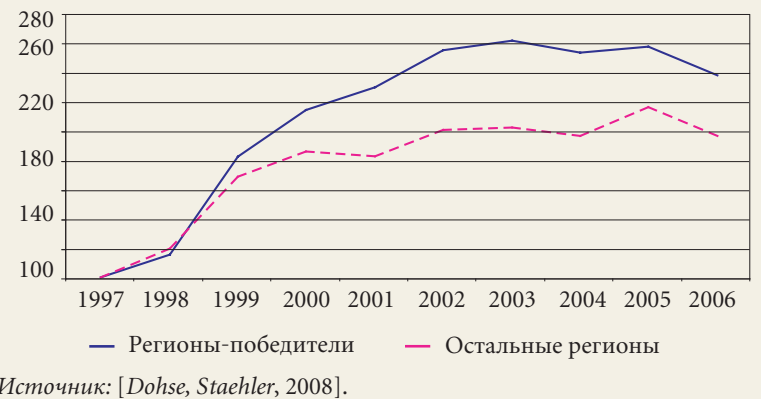

Источник: [Dohse, Staehler, 2008].

Финансирование между обозначенными группами было распределено в соотношении 50\%-25\%-25\% [Karine et al., 2011].

По итогам первых трех лет реализации программы была проведена экспертиза кластеров и инструментов их поддержки, показавшая, что 39 участников решили поставленные задачи полностью; еще 19 - частично, и в будущем должны скорректировать стратегию; 13 - нуждаются в трансформации [Pro Inno Europe, 2009]. В результате Правительство Франции приняло решение продолжить реализацию программы и выделить еще 1.5 млрд евро на следующие три года (2009-2011 гг.).

Анализ европейских программ развития кластеров позволяет выделить ряд их важных особенностей. Вопервых, кластерная политика в большинстве случаев направлена на поддержку высокотехнологичных секторов (биотехнологий, информационных технологий

\section{Табл. 2. Федеральные кластерные программы в Германии}

\begin{tabular}{|c|c|c|c|c|c|c|c|c|c|c|}
\hline \multirow[b]{2}{*}{$\begin{array}{c}\text { Наимено- } \\
\text { вание про-- } \\
\text { граммы }\end{array}$} & \multirow[b]{2}{*}{ Цель } & \multirow[b]{2}{*}{$\begin{array}{c}\text { Объекты } \\
\text { поддержки }\end{array}$} & \multicolumn{3}{|c|}{ Вид поддержки } & \multirow[b]{2}{*}{$\begin{array}{l}\text { Сроки } \\
\text { реализа- } \\
\text { ции }\end{array}$} & \multirow[b]{2}{*}{$\begin{array}{l}\text { Бюджет } \\
\text { (млн } \\
\text { евро) }\end{array}$} & \multirow[b]{2}{*}{$\begin{array}{c}\text { Число } \\
\text { по- } \\
\text { данных } \\
\text { заявок }\end{array}$} & \multirow[b]{2}{*}{$\begin{array}{c}\text { Число } \\
\text { победите- } \\
\text { лей }\end{array}$} & \multirow[b]{2}{*}{$\begin{array}{c}\text { Доля заявок, } \\
\text { не получив- } \\
\text { ших субси- } \\
\text { дии (\%) }\end{array}$} \\
\hline & & & $\begin{array}{l}\text { Финан- } \\
\text { совая }\end{array}$ & $\begin{array}{l}\text { Орга- } \\
\text { низа- } \\
\text { цион-- } \\
\text { ная }\end{array}$ & $\begin{array}{c}\text { Кон- }^{-} \\
\text {сульта- } \\
\text { ционная }\end{array}$ & & & & & \\
\hline BioRegio & $\begin{array}{l}\text { Региональное } \\
\text { сотрудничество в } \\
\text { области биотехно- } \\
\text { логий }\end{array}$ & $\begin{array}{l}\text { НИИ и частные } \\
\text { компании }\end{array}$ & $\mathrm{x}$ & $\mathrm{x}$ & & 1995-2002 & 90 & 17 & 4 & 76 \\
\hline BioProfile & $\begin{array}{l}\text { Региональное } \\
\text { сотрудничество в } \\
\text { области биотехно- } \\
\text { логий }\end{array}$ & $\begin{array}{l}\text { НИИ и частные } \\
\text { компании }\end{array}$ & $\mathrm{x}$ & $\mathrm{x}$ & & 1999-2006 & 50 & 30 & 3 & 90 \\
\hline BioFuture & $\begin{array}{l}\text { Сотрудничество в } \\
\text { области биотехно- } \\
\text { логий }\end{array}$ & $\begin{array}{l}\text { Немецкие и зару- } \\
\text { бежные ученые- } \\
\text { исследователи }\end{array}$ & $\mathrm{x}$ & & & 1998-2010 & 75 & 1000 & 51 & 95 \\
\hline EXIST & $\begin{array}{l}\text { Региональное } \\
\text { сотрудничество }\end{array}$ & $\begin{array}{l}\text { Консорциум- } \\
\text { минимум три } \\
\text { партнера, вклю- } \\
\text { чая университет }\end{array}$ & & $\mathrm{x}$ & $\mathrm{x}$ & 1997-2005 & 50 & 109 & 5 & 95 \\
\hline InnoRegio & $\begin{array}{l}\text { Региональные } \\
\text { сети инноваций }\end{array}$ & $\begin{array}{l}\text { НИИ, универ- } \\
\text { ситеты, частные } \\
\text { компании }\end{array}$ & $\mathrm{x}$ & $\mathrm{x}$ & $\mathrm{x}$ & 1999-2006 & 253 & 444 & 23 & 95 \\
\hline InnoNet & $\begin{array}{l}\text { Сотрудничество } \\
\text { в области ИиР }\end{array}$ & $\begin{array}{l}\text { Частные средние } \\
\text { и малые компа- } \\
\text { нии, НИИ }\end{array}$ & $\mathrm{x}$ & & & 1999-2005 & 33 & 404 & 51 & 87 \\
\hline NEMO & $\begin{array}{l}\text { Сотрудничество } \\
\text { в области ИиР }\end{array}$ & $\begin{array}{l}\text { Частные средние } \\
\text { и малые компа- } \\
\text { нии, НИИ }\end{array}$ & & $\mathrm{x}$ & $\mathrm{x}$ & $2002-2006$ & 3 & 209 & 55 & 73 \\
\hline $\begin{array}{l}\text { Lernende } \\
\text { Regionen }\end{array}$ & $\begin{array}{l}\text { Региональные } \\
\text { сети инноваций }\end{array}$ & $\begin{array}{l}\text { Частные компа- } \\
\text { нии, вузы, НИИ } \\
\text { и т. п. }\end{array}$ & $\mathrm{x}$ & $\mathrm{x}$ & & 2000-2006 & 118 & 350 & 72 & 79 \\
\hline
\end{tabular}


и др.). Традиционные отрасли промышленности и сельское хозяйство также попадают в ее охват, хотя и несколько реже.

Во-вторых, рассмотренные программы предусматривают заявительный порядок получения информации о кластерах для их последующего отбора. Это означает, что власти самостоятельно не определяют наиболее перспективные кластеры (хотя могут устанавливать приоритетные направления поддержки), а организуют конкурс коллективных заявок. Подобным образом построена вышеупомянутая программа во Франции.

Третья характерная черта - принцип конкуренции: поддержку получают далеко не все (в Германии доля отклоненных заявок достигает 95\%), а только лучшие.

B-четвертых, как показывает практика, основными бенефициарами государственных программ выступают малые и средние предприятия. По данным опроса компаний, участвовавших в конкурсе BioRegio, с этим тезисом не согласились лишь 13\% респондентов. На такие компании, большинство из которых - стартапы, пришлось более 60\% общего объема финансирования [Dohse, Staehler, 2008]. Бизнес данной категории преобладал и среди участников InnoRegio [Eickelpasch, 2008]. В случае французской Competitiveness Clusters удельный вес малых и средних фирм составил 80\%, на их долю было выделено в общей сложности 54\% бюджета программы [DGCIS, 2009; Pro Inno Europe, 2009].

Европейские кластерные программы предусматривают достаточно длительные сроки подготовки заявок, а конкурсный отбор проходит в несколько этапов. В Германии практикуется двухступенчатая система: после предварительного отсева оставшимся участникам предлагается детализировать конкурсные предложения. Государство, как правило, компенсирует связанные с этим затраты и оказывает конкурсантам консультационную поддержку. По условиям InnoRegio отобранные на первом этапе кластеры получили гранты в размере 153.4 тыс. евро на углубленную проработку проектов. На второй стадии отбираются проекты-победители для полноформатной государственной поддержки [Eickelpasch et al., 2002; Eickelpasch, Fritsch, 2005].

За реализацию кластерной стратегии, как правило, отвечают сразу несколько национальных ведомств. В большинстве европейских стран их число не превышает трех [Oxford Research, 2008]; в Ирландии оно достигает семи, а в Финляндии - даже восьми. В частности, BioRegio предусматривала обеспечение не только из собственного бюджета (90 млн евро), но и привлечение средств из других федеральных и региональных программ (прежде всего, «Biotechnology-2000»), в результате чего консорциумы-победители получили финансирование на общую сумму более 700 млн евро [OECD, 2007; Eickelpasch, Fritsch, 2005].

В структуру зарубежных программ обычно заложены мероприятия по мониторингу и оценке. Например, в ходе InnoRegio проводился анализ факторов, способствующих сотрудничеству между кластерами (сетями) и обмену лучшими практиками.
Итогом экспертизы стали рекомендации по совершенствованию программы [Eickelpasch et al., 2002]. Не менее основательно выстроена система мониторинга в рамках французской программы Competitiveness Clusters, предполагающая ежегодную оценку показателей с открытой публикацией результатов в Сети. После завершения первой фазы в 2008 г. была осуществлена независимая экспертиза всех поддерживаемых проектов.

Помимо отмеченных особенностей, практике реализации европейских программ присущи определенные недостатки и ограничения. В отношении Германии эксперты указывают на следующие проблемы [Eickelpasch, Fritsch, 2005]:

- значительные организационные усилия и временные затраты на организацию конкурсов, экспертизу заявок, доработку проектов и т. п.;

- недостаточная административная гибкость при адаптировании дизайна проектов к потребностям поддерживаемых компаний;

- сложности в противостоянии лоббистским группировкам, претендующим на государственную поддержку (в случае отсутствия прозрачной и справедливой процедуры отбора возникает опасность дискредитации всей программы);

- наличие временного лага между моментом завершения конкурса и началом оказания конкретных мер поддержки. Например, в BioRegio и EXIST такой промежуток составил около одного, а в InnoRegio - почти два года.

Одним из существенных минусов французской программы Competitiveness Clusters считается слишком большое число поддерживаемых кластеров. Вместо запланированных 15 был отобран 71 кластер, доля отклоненных заявок оказалась гораздо ниже, чем в Германии (32\% против 80-90\%). В силу этого конкурсный комитет, в котором преобладали представители государственных ведомств, подвергся серьезной критике, ведь кластерная политика, по определению, должна быть направлена на поддержку лучших, наиболее перспективных кластеров мирового класса, а не проблемных, нуждающихся в ресурсах либо решающих социальные или политические задачи.

\section{Контуры кластерной политики в России}

Основополагающим документом, прописывающим рамки кластерной политики, является «Концепция долгосрочного социально-экономического развития Российской Федерации на период до 2020 года». Одним из ключевых условий модернизации экономики и реализации конкурентного потенциала регионов обозначено создание сети территориальнопроизводственных кластеров. Предусматривается формирование двух типов кластеров - инновационных высокотехнологичных (в урбанизированных регионах) и территориально-производственных (на слабоосвоенных территориях, ориентированных на глубокую переработку сырья и производство энергии с использованием современных технологий). Намечено создание не менее восьми инновационных высокотехнологичных кластеров, однако их территориальная локализация, отраслевая принадлежность 
и роль в развитии промышленного и инновационного потенциала страны не уточняются. В качестве примера территориально-производственного кластера в Концепции рассматривается кластер нефтеи газодобычи на месторождениях Приямальского шельфа Карского моря. Термин «территориальнопроизводственный кластер» используется исключительно в целях обновления понятийного аппарата разработанного еще в советский период подхода к развитию территориально-производственных комплексов (ТПК), хотя, на наш взгляд, подобная подмена терминов не вполне корректна. Следует учитывать, что формирование ТПК может происходить и в условиях рыночной экономики, но для регионов нового освоения, в то время как процессы создания территориальных кластеров «с нуля» признаны неэффективными.

На необходимости поддержки кластерных инициатив акцентирует внимание и «Стратегия инновационного развития Российской Федерации на период до 2020 года». Предполагается, что формирование территорий инновационного развития и инновационных кластеров будет способствовать активизации новаторской деятельности. На первом этапе (2011-2013 гг.) проводятся пилотные проекты по отработке механизмов поддержки кластерных инициатив. Развитие кластеров будет стимулироваться софинансированием из федерального бюджета региональных программ содействия малому бизнесу и дополнительной поддержкой регионов, активно инвестирующих в создание своей инновационной системы. До 2016 г. планируется создать 30 центров кластерного развития, из них к обозначенному сроку удвоения объемов высокотехнологичного экспорта должны достичь четыре, а к 2020 г. - семь ${ }^{2}$.

Помимо упомянутых стратегических документов в 2007-2008 гг. Минэкономразвития России были разработаны проект «Концепции кластерной политики в Российской Федерации» и «Методические рекомендации по реализации кластерной политики в субъектах Российской Федерации». В них отмечено, что кластерный подход занял одно из ключевых мест в социально-экономических стратегиях ряда регионов и муниципальных образований. Некоторые проекты развития территориально-производственных кластеров осуществляются в инициативном порядке.

Серьезным опытом в применении инструментов кластеризации обладают в первую очередь промышленно развитые регионы страны, где продвижение кластеров рассматривается администрациями в качестве основы промышленной политики ${ }^{3}$. Так, «Стратегия социально-экономического развития Самарской об ласти до 2030 года» отводит кластерному подходу исключительную роль в развитии промышленного сектора. Различной степенью институциализации и интенсивности применения кластерных программ характеризуются Республика Татарстан, Пермский край, Калужская, Липецкая, Томская, Иркутская области, Санкт-Петербург и др. Возможности внедрения кластерных принципов в систему управления региональным развитием прорабатываются и в ходе подготовки «Стратегии развития Москвы на период до 2025 года».

Наличие определенного задела в реализации кластерных проектов в значительной мере обусловлено инициативами государства первой половины 2000-х гг., нацеленными на укрепление инфраструктуры поддержки инновационной деятельности и сложившихся еще в советский период центров концентрации высокотехнологичных производств. В последние годы федеральная власть, наработав соответствующую инструментальную базу в виде стратегий, концепций и методических рекомендаций, переходит к практическому осуществлению кластерной политики, оказывая содействие конкретным локальным проектам.

С 2010 г. Минэкономразвития предоставляет субсидии регионам для создания и функционирования центров кластерного развития как одного из инструментов поддержки малого и среднего предпринимательства ${ }^{4}$. В начале 2012 г. был объявлен конкурс по отбору пилотных программ развития инновационных территориальных кластеров ${ }^{5}$, нацеленный на идентификацию и стимулирование наиболее конкурентоспособных из них. Для минимизации риска поддержки кластеров, достигших высоких производственных показателей, но не имеющих существенного потенциала роста, оценивались как текущий уровень, так и перспективы развития, включая проработанность мероприятий по соответствующим направлениям деятельности. Каждый из упомянутых критериев признавался в равной степени важным. По итогам конкурса из 94 заявленных проектов Рабочей группой по развитию частно-государственного партнерства в инновационной сфере при Правительственной комиссии по высоким технологиям и инновациям были отобраны 25 пилотных программ, представляющих мощный конгломерат научно-производственных центров (табл. 3)6. Они были поделены на две группы. Кластерам первой категории (всего - 14) будут предоставлены субсидии из госбюджета. Ко второй отнесены 11 кластеров, чьи программы развития требуют доработки, а потому на первом этапе их финансирование на федеральном уровне не предполагается (рис. 5). В конце августа 2012 г. перечень из 25 пилотных программ развития инновационных территориальных кластеров был одобрен Правительством Российской Федерации.

\footnotetext{
Данный целевой ориентир, по нашему мнению, входит в некоторое противоречие с последними инициативами Правительства России, направленными на поддержку инновационных территориальных кластеров. Удвоения высокотехнологичного экспорта в среднесрочной перспективе способны достичь лишь динамично развивающиеся кластеры. В рамках рассматриваемого ниже конкурсного отбора пилотных проектов развития инновационных территориальных кластеров планируются субсидии для развитых кластеров, уже сегодня характеризующихся значительными объемами высокотехнологичного экспорта. Достижение указанного ориентира для отобранных инновационных кластеров станет весьма сложной задачей (особенно в период до 2016 г.), учитывая, что запуск поддерживающих кластеры механизмов и выделение субсидий из федерального бюджета планируется не ранее 2013 г.

Кластерные проекты встречаются также в сфере услуг (туристические кластеры) и сельском хозяйстве.

4 Центры кластерного развития созданы в Москве, Самарской, Томской, Калужской, Астраханской, Свердловской, Пензенской, Ульяновской областях, Республике Татарстан и ряде других регионов.

5 Согласно поручению Президента РФ по итогам заседания президиума Государственного совета от 11 ноября 2011 г. (протокол № Пр-3484ГС от 22 ноября 2011 г., п. 2в), а также решениям Правительственной комиссии по высоким технологиям и инновациям от 30 января 2012 г. (протокол № 1, раздел I, п. 6)

6 Подробнее о конкурсе и его итогах см.: http://cluster.hse.ru/
} 

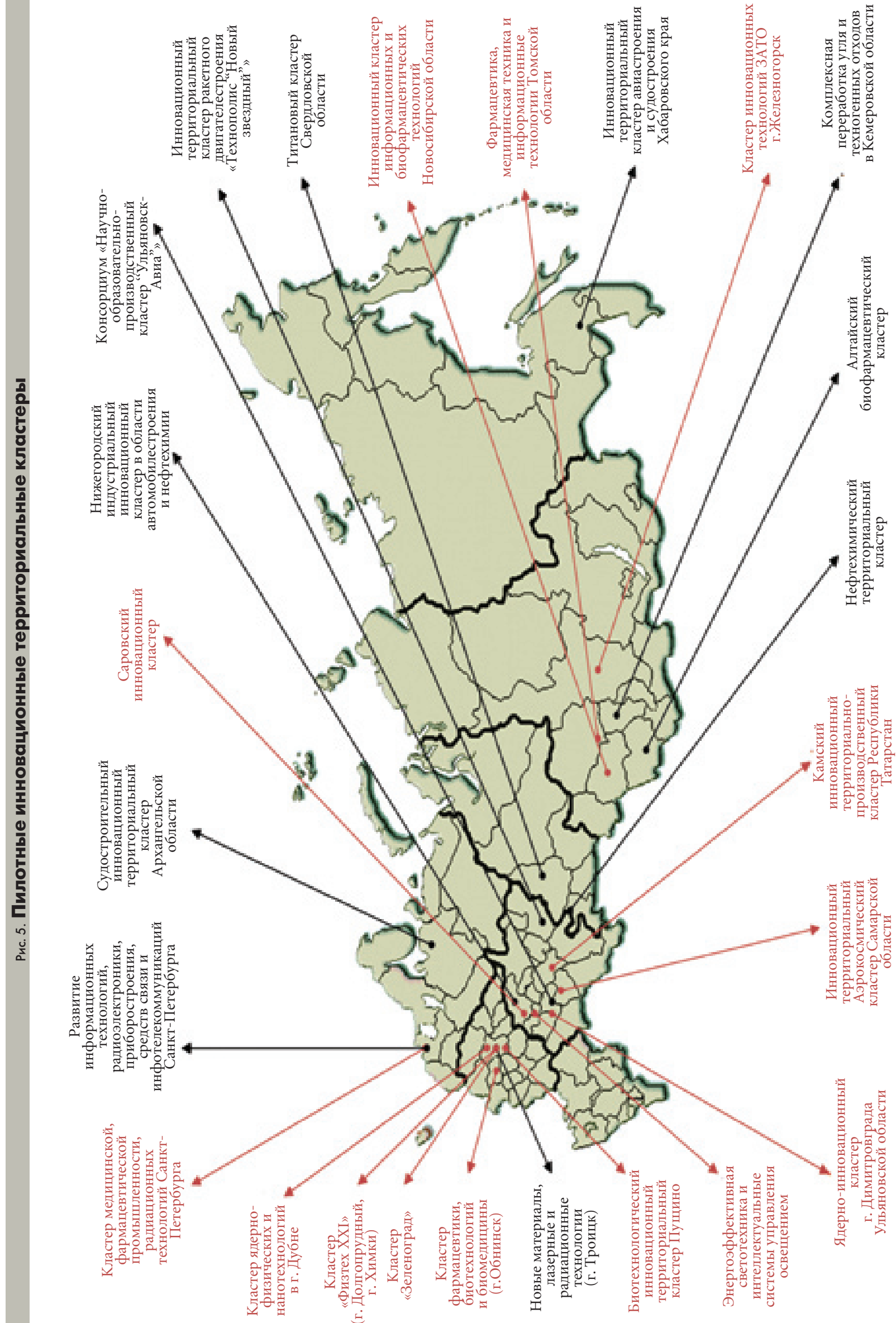

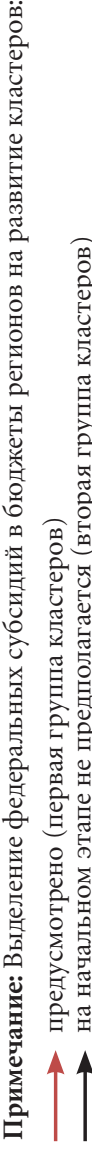


Рис. 6. Направления использования субсидий из средств федерального бюджета в 20132017 гr. по предложениям 14 пилотных инновационных территориальных кластеров (\%)

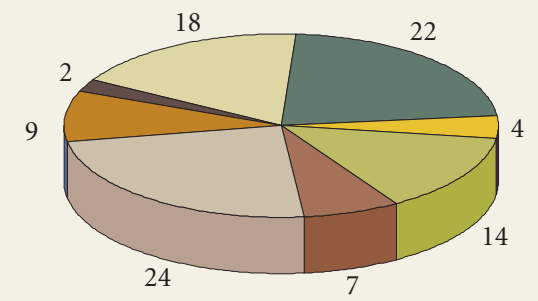

$\square$ Транспортная инфраструктура

$\square$ Энергетическая инфраструктура

$\square$ Инженерная инфраструктура

Ж Жилищная инфраструктура

$\square$ Инновационная инфраструктура

$\square$ Образовательная инфраструктура

- Материально-техническая база, культура и спорт

$\square$ Проекты в сфере исследований и разработок, инновационной деятельности, подготовки и повышения квалификации кадров и др.

Источник: [Минэкономразвития России, 2012].

Начиная с 2013 г. в течение пяти лет предполагается ежегодно выделять победителям субсидии, раз меры которых будут дифференцированы с учетом потребностей конкретных кластеров (рис. 6). Другим инструментом содействия кластерным проектам станут федеральные целевые программы, государственные программы Российской Федерации и внебюджетные фонды. Ключевая роль отводится также поддержке со стороны государственных институтов развития, включая Внешэкономбанк, Российскую венчурную компанию, РОСНАНО, Российский фонд технологического развития, Фонд содействия развитию малых форм предприятий в научно-технической сфере, Фонд развития Центра разработки и коммерциализации новых технологий («Сколково»), Фонд инфраструктурных и образовательных программ [Минэкономразвития России, 2012]. Ожидается, что благодаря таким партнерствам удастся сформировать «инновационный лифт», способствующий коммерциализации и трансферу технологий.
Существенным стимулом в развитии пилотных кластеров может стать применение к ним отдельных механизмов поддержки, законодательно предусмотренных для иннограда «Сколково» (налоговых льгот, специфических регуляторных инструментов и т. п.). Планируется также, что Фонд «Сколково» окажет кластерам содействие в привлечении прямых иностранных инвестиций. Наряду с этим рассматриваются возможности взаимодействия между членами кластеров и компаниями с государственным участием в рамках программ инновационного развития последних.

В завершение отметим, что ключевой задачей государства является интеграция кластерных механизмов с другими инструментами в сфере науки, технологий, инноваций, образования, малого и среднего предпринимательства, регионального развития, регулирования деятельности компаний с государственным участием как основа выработки полноценной инновационной политики.

\section{Факторы успеха}

Анализируя ситуацию с формированием кластерной политики в России, попытаемся определить факторы, способствующие ее успеху, включая критерии и процедуры отбора пилотных проектов, пакет мер государственной поддержки, механизмы информационного и аналитического обеспечения.

Как уже упоминалось, кластеры нацелены на стимулирование кооперации между бизнесом, наукой и государством в целях повышения инновационной активности в регионе. При этом важна четко выраженная инициатива со стороны бизнеса, играющего решающую роль в коммерциализации нововведений. Результативность модернизации экономики в настоящее время существенно ограничена из-за низкой инновационной активности компаний и их слабого отклика на инициативы властей.

Значителен риск того, что основными бенефициарами в кластерах станут организации, находящиеся в собственности государства либо получающие от него финансирование (компании с госучастием, частные фирмы, их дочерние и зависимые общества, крупные вузы и научно-исследовательские институты).

Табл. з. Сводные показатели пилотных инновационных территориальных кластеров

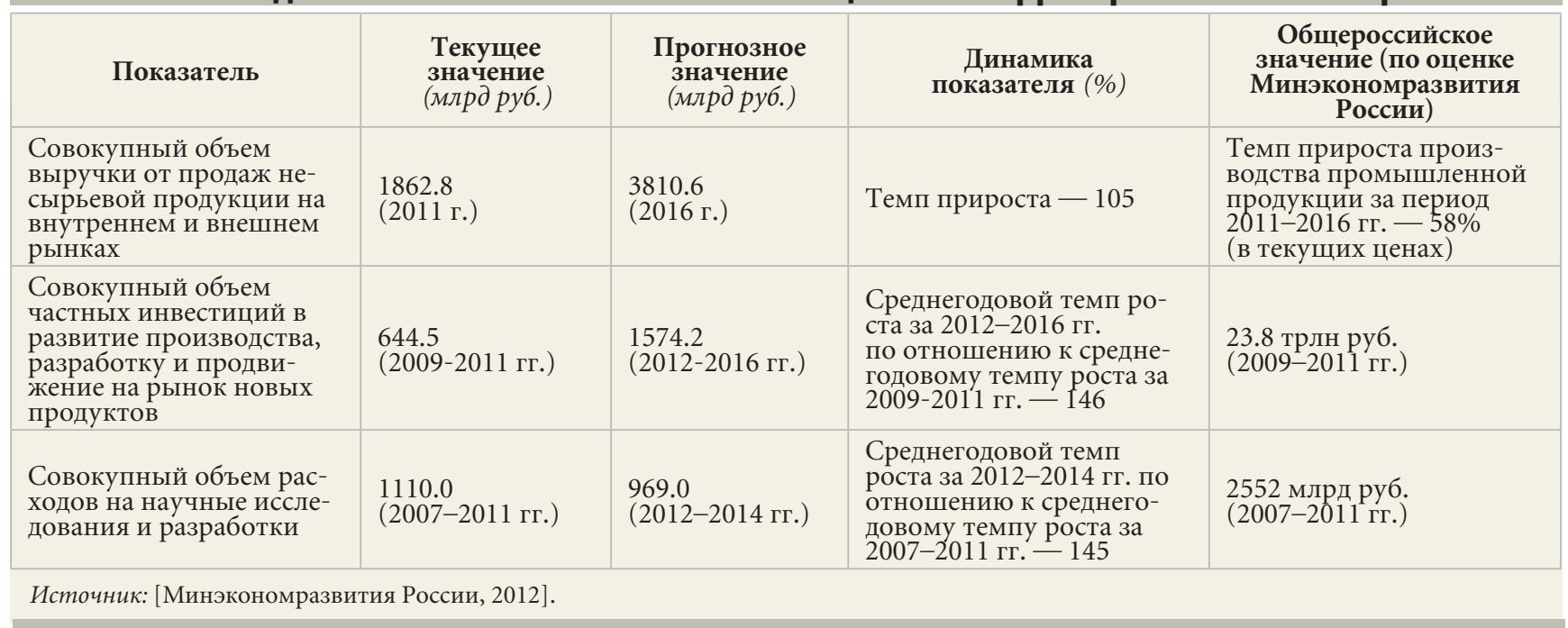


В данной ситуации благотворный для инноваций эффект «тройной спирали» (triple helix) [Etzkowitz, 2010] может быть ограничен бюрократическими согласованиями, что приведет к снижению конкуренции и подавлению стимулов к инновациям.

Поскольку сама идея кластера состоит в обеспечении взаимодействия между участниками, значимым критерием отбора является наличие совместных инициатив, приносящих выгоду всем участникам. Если преимущества извлекает лишь один актор или их ограниченное число (а другие игроки, возможно, несут потери), такой проект не должен считаться кластерным. К подобным проектам вряд ли можно отнести и те, что выполняются крупным предприятием-участником с привлечением субподрядчиков, хотя двусторонние контракты подряда, найма, купли-продажи и т. п. предполагают добровольное и обоюдовыгодное взаимодействие сторон. Кластерная «синергия» заключается в распределении финансовых и иных ресурсных затрат, а также рисков между всеми участниками, а ее результатом является решение общих проблем. В «портфель» совместных проектов часто входят создание инфраструктуры, включая инновационную, например, центра коллективного пользования оборудованием; организация консорциумов для участия в крупных заказах по линии госзакупок, транснациональных компаний и т. п.; инициативы, связанные с маркетингом и продвижением кластера (коллективный бренд, совместное участие в выставках и публичных мероприятиях и др.), повышением квалификации работников, и др.

О наличии коллаборативных проектов косвенно свидетельствуют качество согласовательного процесса, проведение специальных мероприятий по обсуждению стратегий и планов совместных действий. Если же при формировании кластерной программы доминирует один из участников, вполне возможно, что принятые «наспех» договоренности и проекты окажутся ненадежными, а кластер так и не возникнет, даже при наличии государственной поддержки.

Особое внимание к потребностям малых и средних предприятий обусловлено высокой заинтересованностью в кооперации, так как в силу ограниченных размеров они часто не могут в одиночку решать задачи по повышению инновационной активности и конкурентоспособности. Тем не менее существует вероятность, что бенефициарами государственных инициатив станут преимущественно крупные компании, для которых кластерный формат взаимодействия далеко не всегда актуален. В большинстве случаев им проще самостоятельно организовать проект или решить проблемы путем привлечения заемного финансирования, в рамках частно-государственного партнерства и т. д. Следует учитывать, что проектные потребности корпораций часто превосходят объемы предполагаемых субсидий и далеко не всегда могут быть удовлетворены на уровне кластера или региона (например, если речь идет о сферах деятельности, зависящих от государственных закупок).
Несмотря на то что показатели малого и среднего бизнеса включены в систему оценки программ развития, формального присутствия таких предприятий недостаточно: не исключен вариант, при котором они искусственно «пристегиваются» к кластеру, реально не участвуя в совместных проектах. В связи с этим было бы правильным оценивать степень вовлеченности подобного рода фирм в совместные инициативы и значимость последних для развития кластера.

Предпочтительно, чтобы в поддерживаемые кластеры включались «газели» - быстрорастущие компании с большим потенциалом и перспективами, привлекательные для поставщиков, сервисных организаций и пр. К ним относятся фирмы, демонстрирующие ежегодный прирост продаж от 20\% на протяжении не менее четырех лет [Юданољ, 2007; Виньков, Полунин, 2011]. Маловероятно, что при отсутствии подобных игроков удастся обеспечить прорыв и, как следствие, возможность для кластера стать точкой роста региональной экономики. Поэтому при оценке программ развития необходимо обращать внимание не столько на число «якорных» компаний ${ }^{7}$ и на показатели совокупной выручки предприятий кластера, сколько на участие быстрорастущего бизнеса.

Негативный эффект может иметь стремление включить в состав кластера как можно больше «брендовых» участников - крупнейшие предприятия, известные вузы и научные организации. При этом возникает риск утраты территориального либо отраслевого фокуса. Ценность географической концентрации в том, что она рождает специфические внешние эффекты, положительно влияющие на конкурентоспособность участников кластера. Именно по наличию таких эффектов можно судить о содержательном, а не формальном функционировании альянса. Если кластер рассредоточен географически, возникают вопросы, не является ли он искусственной конструкцией, созданной, к примеру, «под конкурс»; насколько данная структура жизнеспособна и имеет ли потенциал развития. Возможны ситуации, когда предприятия дистанцированы друг от друга в границах региона (или находятся в разных регионах), но эти случаи требуют дополнительного обоснования с позиций наличия кооперационных связей между территориально удаленными сегментами.

Не менее распространенным явлением при формировании кластера является размывание его отраслевых границ. В этом случае снижается значимость связей между участниками, их взаимодействие ограничивается несколькими темами (проектами). Узкое пространство для взаимодействия и различия в логике отраслевой динамики отдельных акторов существенно редуцируют возможности развития кластера как единого комплекса. Кроме того, агрегация видов деятельности участников размывает его ключевые компетенции. Необходимо четко определить виды деятельности, продукты, технологии, являющиеся сильными сторонами, уникальными конкурентными преимуществами кластера.

В конкурсе Минэкономразвития критерии отбора ориентированы на компании с выручкой свыше 1 млрд руб. 
Для оценки степени тематической сфокусированности следует проанализировать уровень связанности друг с другом крупных «якорных» компаний, относящихся к различным секторам экономики ${ }^{8}$. Показателем территориальной и отраслевой сфокусированности кластера может служить степень участия в совместных проектах организаций из разных отраслей и мест дислокации. Полагаем, что секторальная и территориальная вариативность игроков является оправданной только при условии тесной кооперации.

Учитывая основную задачу кластерной политики, интегральным критерием выбора пилотных кластеров должен стать потенциал выхода организацийучастников в лидеры мировых рынков. В Европе к такому выводу пришли около пяти лет назад, когда наметился переход от практики содействия всем кластерам вообще к поддержке игроков мирового уровня [VINNOVA, 2008]. Данный критерий фигурировал в конкурсе Минэкономразвития, но его значимость среди других индикаторов в дальнейшем целесообразно усилить.

Значимую роль в результативности политики играет качество конкурсных процедур. В соответствии с мировым опытом считаем целесообразным разделить процесс отбора кластерных программ на два этапа. Вначале оцениваются конкурсные заявки, из которых отсеиваются слабые и неперспективные. Прошедшим первоначальный отбор кластерам предоставляется дополнительное время (два-три месяца) на доработку заявок. Это позволит улучшить сами заявки и протестировать кластерный формат взаимодействия (в процессе согласования видения, целей, стратегий участников, а также разработки совместных проектов). Если кластер окажется действенным инструментом повышения конкурентоспособности, он сможет развиваться и без государственной поддержки.

Как показано выше, одним из базовых принципов реализации кластерных программ за рубежом является системность. Поддержка должна оказываться по различным направлениям в соответствии с потребностями (т. е. разработанными совместными проектами) и ориентироваться на достижение глобальной конкурентоспособности. В числе возможных мер:

- предоставление земельных площадей и оборудованных помещений для концентрации участников (промышленные и технопарки);

- разработка, внедрение и сертификация систем менеджмента в области управления качеством, экологической безопасности и охраны труда;

- система поиска поставщиков и исполнителей;

- содействие организации консорциумов для совместного участия в крупных заказах;

- поддержка в маркетинговом продвижении продукции на региональных, национальных и зарубежных рынках (профильные выставки, создание и развитие коллективного бренда, информирова ние заказчиков о преимуществах инновационной продукции и др.);

- создание площадок для взаимодействия (специализированного сайта, конференций, форумов и т. п.);
- формирование инновационной инфраструктуры (испытательные лаборатории, центры трансфера технологий, коллективного пользования оборудованием, прототипирования, промышленного дизайна и др.);

- налаживание контактов участников с научными и образовательными организациями.

Эффективная политика предполагает преодоление ведомственной разобщенности. Кластерам должна оказываться скоординированная поддержка со стороны власти и институтов развития. Отсутствие координации может привести к тому, что под каждую программу будут искусственно формироваться отдельные кластеры, и, как следствие, к распылению средств и отсутствию запланированных результатов. Ближайшая зона риска - негласное разделение региональных программ для малого и среднего бизнеса с поддержкой крупных компаний в рамках конкурса пилотных кластеров. Реализация этого сценария приведет к формированию квази-кластерных образований, не имеющих достаточной мотивации для сотрудничества помимо получения государственного финансирования.

Остается открытым вопрос о направлениях поддержки. На международном уровне приоритет отдается содействию инновационной деятельности - от развития исследовательских проектов и «мягкой» (инновационной) инфраструктуры до совместного маркетинга, организационных инноваций и т. д. Это касается как высокотехнологичных кластеров, так и специализирующихся на традиционных видах промышленной или сельскохозяйственной деятельности. В России складывается обратная ситуация: поддерживаются кластеры со значительной инновационной компонентой, но подавляющая часть средств инвестируется в базовую физическую инфраструктуру - транспортную, энергетическую и жилищно-коммунальную. Очевидно, что без удовлетворения инфраструктурных потребностей сложно ожидать ускоренного инновационного развития, но подобные задачи, по-видимому, следует решать за счет иных программ, а само развитие базовой инфраструктуры должно предшествовать кластерной политике, не смешиваясь с ней. Это позволит сфокусировать ресурсы и инструменты на стимулировании кооперационных взаимодействий, позволяющих результативно развивать потенциал каждого участника.

Кластеры представляют собой развивающиеся системы. Успешные сегодня в силу разных причин (в том числе внешних - научно-технический прогресс, изменение мировой конъюнктуры и т. д.), завтра они могут утратить динамизм и перспективы. Другие кластеры, напротив, на старте стремительно растут, затем сталкиваются с разнообразными барьерами и ограничениями, в силу которых реализация совместных проектов может затянуться на годы, а достижение зрелости занять не одно десятилетие. Здесь потребуется оценка влияния кластерных проектов на параметры региональной и национальной инновационной системы. 


\section{Стратегии}

Учитывая длительность кластерных проектов, высока вероятность незапланированных изменений. Разница в динамике и эффективности развития кластеров провоцирует новые риски для политики: она может потерять свою результативность, если исходный выбор объектов для поддержки впоследствии окажется неоптимальным (и даже ошибочным). Фундаментальная причина этих рисков кроется в том, что государство устраняется от совместной работы над развитием кластера после выделения субсидий и оказания первоначальной поддержки. Ввиду сказанного необходимы постоянный мониторинг и оценка результативности деятельности кластеров, служащие информационной основой для последующей корректировки перечня объектов, размеров и механизмов развития.

\section{Заключение}

Часть приведенных в статье рекомендаций по совершенствованию национальной кластерной политики может быть реализована в ближайшем будущем, и тем самым может быть повышена эффективность разрабатываемой федеральной программы поддержки кластеров. Другие (связанные с критериями и процедурами отбора), по всей вероятности, обретут актуальность на этапе запуска новых программ, в частности - второй волны отбора кластеров. В любом случае, учет передового опыта в реализации такого рода инструментов инновационной политики позволит избежать возможных ошибок.

Предстоит тщательно проанализировать и внутреннюю практику - механизм развития кластеров, наиболее востребованные меры господдержки и их эффективность. Необходимы также каналы обратной связи от участников кластеров и действенные коммуникационные площадки. Столпами кластерной политики в России должны стать гибкость и адаптивность. Ее результативность будет напрямую зависеть от способности государства оперативно реагировать на внешнюю и внутреннюю конъюнктуру, меняющуюся социально-экономическую ситуацию и новые потребности развивающихся кластеров.

Виньков А., Полунин Ю. (2011) Ермаки и Эдисоны // Эксперт. № 20 (754). С. 19-43.

Минэкономразвития России (2012) Проект перечня пилотных программ развития инновационных территориальных кластеров. Минэкономразвития России. http://www.economy.gov.ru/minec/activity/sections/innovations/politic/ (дата доступа 15 августа 2012 г.). Юданов А. (2007) Гении национального бизнеса // Эксперт. №16 (557). С. 33-41.

BMBF (2006) InnoRegio. Bundesministerium fur Bilding und Forschung. http://www.unternehmen-region.de/en/159.php (accessed 13 July 2012).

DGCIS (2009) Competitiveness Clusters in France. General Directorate for Competitiveness, Industry and Services. http://www.industrie. gouv.fr/poles-competitivite/brochure-en.html (accessed 10 July 2012).

Dohse D., Staehler T. (2008) BioRegio, BioProfile and the Rise of the German Biotech Industry (Working Paper № 1456). Kiel, Germany. http://www.ifw-members.ifw-kiel.de/publications/bioregio-bioprofile-and-the-growth-of-the-german-biotech-industry/KWP_1456.pdf (accessed 16 August 2012).

Eickelpasch A., Kauffeld M., Pfeiffer I. (2002) The InnoRegio-Program: A new way to promote regional innovation networks - Empirical results of the complementary research. Berlin: DIW.

Eickelpasch A., Fritsch M. (2005) Contests for Cooperation - A New Approach in German Innovation Policy // Research Policy. № 34. P. $1269-1282$.

Eickelpasch A. (2008) The Promotion of Regional Innovative Networks - Lessons from the German InnoRegio-Programme. Paper presented at the Final DISTRICT Conference «Innovation Pathways and Knowledge Economy», 16 April 2008, Brussels.

Etzkowitz H. (2010) The Capitalization of Knowledge: A Triple Helix of University-Industry-Government. Cheltenham: Edward Elgar.

European Commission (2002) Innovation Tomorrow. Innovation Policy and the Regulatory Framework: Making Innovation an Integral Part of the Broader Structural Agenda. Innovation Directorate EUR report № 17502. Brussels: Official Publications of the European Communities.

Karine D., Nejla B., Fanny F., Sylvain A. (2011) Agri-Food Clusters: Is French Policy in Line with Real Spatial Dynamics? Paper presented at the Special Session of AESJ2011, Tokyo. http://www-sre.wu.ac.at/ersa/ersaconfs/ersa11/e110830aFinal01848.pdf (accessed 7 August 2012).

Ketels C., Lindqvist G., Sölvell Ö. (2006) Cluster Initiatives in Developing and Transition Economies. Stockholm: Center for Strategy and Competitiveness.

Larosse J. (2004) Towards a «Third Generation»» Innovation Policy in Flanders: Policy Profile of the Flemish Innovation System. Contribution to the OECD-TIP project MONIT (Monitoring and Implementing Horizontal Innovation Policies). IWT-Observatory.

OECD (2007) Competitive Regional Clusters: National Policy Approaches. Paris: OECD.

Oxford Research (2008) Cluster Policy in Europe. A Brief Summary of Cluster Policies in 31 European Countries. Oxford Research AS.2008. http://www.clusterobservatory.eu/system/modules/com.gridnine.opencms.modules.eco/providers/getpdf.jsp?uid=100146 (accessed 2 June 2012).

Pro Inno Europe (2009) INNO-PolicyTrendChart. http://proinno.intrasoft.be/index.cfm?fuseaction=wiw.measures\&page=detail\&ID=8922 (accessed 26 July 2012).

Research in Germany (2011) BioRegio and BioProfile Competitions. http://research-in-germany.org/research-areas/biotechnology/2-nr-1programmes-initiatives/42162/3-nr-6-bioregio-und-bioprofile.html (accessed 24 June 2012).

Sölvell Ö., Lindqvist G., Ketels C. (2003) The Cluster Initiative Greenbook. Stockholm: Bromma Tryck AB.

VINNOVA (2008) European Cluster Memorandum. http://www.vinnova.se/In-English/misc/Speciella_sidor/Innovation-and-Clusters/ (accessed 12 August 2012). 


\title{
Cluster Policy in Russia: From Theory to Practice
}

\author{
Vasily Abashkin \\ Senior Research Fellow, Centre for S\&T, Innovation and Information Policy. E-mail: vabashkin@hse.ru
}

Arthur Boyarov

Senior Research Fellow, Division for Private-Public Partnerships in Innovation. E-mail: boyarov@hse.ru

Evgeniy Kutsenko

Senior Research Fellow. E-mail: ekutsenko@hse.ru

Institute for Statistical Studies and Economics of Knowledge, National Research University Higher School of Economics

Address: National Research University Higher School of Economics, 20, Myasnitskaya str., Moscow, 101000.

\begin{abstract}
A $\mathrm{n}$ extensive development of industrial clusters in numerous regions worldwide is determined by wide opportunities for economic growth and a series of positive ripple effects. According to international practice, developing a cluster strategy is an important step towards building a fully-fledged innovation policy toolkit; moreover it gives evidence of a well thought out long-term approach by government to overall development of territories and economic sectors.

At present the Russian government has moved from conceptual frameworks to implementation of specific cluster initiatives. However using tools that have originated abroad in the Russian context requires a thorough analysis

of intrinsic barriers reducing the efficiency of innovation development programmes. Direct borrowing of institutions and mechanisms from practices of leading countries rarely leads to desired outcomes. While using even advanced policy tools it is important to take into account specifics of the target environment, pay a special attention to details, not only to general frameworks and principles of incorporated institutes.

The main aim of this paper is to find and rationalize key success factors for the emerging national system of supporting regional clusters. To that end it compares the best international practices and specifics of implementing cluster policy in Russia.
\end{abstract}

\section{Keywords}

government programmes; cluster policy; innovation policy; cluster; stakeholder interaction; innovation development.

\section{References}

BMBF (2006) InnoRegio. Bundesministerium fur Bilding und Forschung. Available at: http://www.unternehmen-region.de/en/159.php (accessed 13 July 2012)

DGCIS (2009) Competitiveness Clusters in France. General Directorate for Competitiveness, Industry and Services. Available at: http://www. industrie.gouv.fr/poles-competitivite/brochure-en.html (accessed 10 July 2012).

Dohse D., Staehler T. (2008) BioRegio, BioProfile and the Rise of the German Biotech Industry (Working Paper no 1456), Kiel, Germany. Available at: http://www.ifw-members.ifw-kiel.de/publications/bioregio-bioprofile-and-the-growth-of-the-german-biotech-industry/KWP_1456.pdf (accessed 16 August 2012).

Eickelpasch A. (2008) The Promotion of Regional Innovative Networks - Lessons from the German InnoRegio-Programme. Paper presented at the Final DISTRICT Conference «Innovation Pathways and Knowledge Economy», 16 April 2008, Brussels.

Eickelpasch A., Fritsch M. (2005) Contests for Cooperation - A New Approach in German Innovation Policy. Research Policy, no 34, pp. 12691282 .

Eickelpasch A., Kauffeld M., Pfeiffer I. (2002) The InnoRegio - Program: A New Way to Promote Regional Innovation Networks - Empirical Results of the Complementary Research, Berlin: DIW.

Etzkowitz H. (2010) The Capitalization of Knowledge: A Triple Helix of University-Industry-Government, Cheltenham: Edward Elgar.

European Commission (2002) Innovation Tomorrow. Innovation Policy and the Regulatory Framework: Making Innovation an Integral Part of the Broader Structural Agenda (Innovation Directorate EUR report no 17502), Brussels: Official Publications of the European Communities.

Karine D., Nejla B., Fanny F., Sylvain A. (2011) Agri-Food Clusters: Is French Policy in Line with Real Spatial Dynamics? Paper presented at the Special Session of AESJ2011, Tokyo. Available at: http://www-sre.wu.ac.at/ersa/ersaconfs/ersa11/e110830aFinal01848.pdf (accessed 7 August 2012).

Ketels C., Lindqvist G., Sölvell Ö. (2006) Cluster Initiatives in Developing and Transition Economies, Stockholm: Center for Strategy and Competitiveness.

Larosse J. (2004) Towards a «Third Generation» Innovation Policy in Flanders: Policy Profile of the Flemish Innovation System. Contribution to the OECD-TIP project MONIT (Monitoring and Implementing Horizontal Innovation Policies). IWT-Observatory.

MED (2012) Proekt perechnya pilotnykh programm razvitiya innovatsionnykh territorial'nykh klasterov [Preliminary List of Pilot Programmes for the Developing Innovation Regional Clusters], Ministry of Economic Development of the Russian Federation. Available at: http://www.economy.gov. $\mathrm{ru} / \mathrm{minec} /$ activity/sections/innovations/politic/ (accessed 15 August 2012).

OECD (2007) Competitive Regional Clusters: National Policy Approaches, Paris: OECD.

Oxford Research (2008) Cluster Policy in Europe. A Brief Summary of Cluster Policies in 31 European Countries. Oxford Research AS.2008. Available at: http://www.clusterobservatory.eu/system/modules/com.gridnine.opencms.modules.eco/providers/getpdf.jsp?uid=100146 (accessed 2 June 2012).

Pro Inno Europe (2009) INNO-PolicyTrendChart. Available at: http://proinno.intrasoft.be/index.cfm?fuseaction=wiw. measures\&page $=$ detail $\& I D=8922($ accessed 26 July 2012).

Research in Germany (2011) BioRegio and BioProfile Competitions. Available at: http://research-in-germany.org/research-areas/biotechnology/2-nr1-programmes-initiatives/42162/3-nr-6-bioregio-und-bioprofile.html (accessed 24 June 2012).

Sölvell O., Lindqvist G., Ketels C. (2003) The Cluster Initiative Greenbook, Stockholm: Bromma Tryck AB

Vin'kov A., Polunin Yu. (2011) Ermaki i Edisony. Ekspert, no 20 (754), pp. 19-43.

VINNOVA (2008) European Cluster Memorandum. Available at: http://www.vinnova.se/In-English/misc/Speciella_sidor/Innovation-and-Clusters/ (accessed 12 August 2012).

Yudanov A. (2007) Genii natsional'nogo biznesa [Genies of National Business]. Ekspert, no 16 (557). Available at: http://expert.ru/expert/2007/16/ genii_nacionalnogo_biznesa/ (accessed 12 June 2012). 


\section{Формирование приоритетов инновационной политики и оценка их реализации: европейский опыт и уроки для Украины ${ }^{1}$}

\section{Г. Румп $\phi^{*}$}

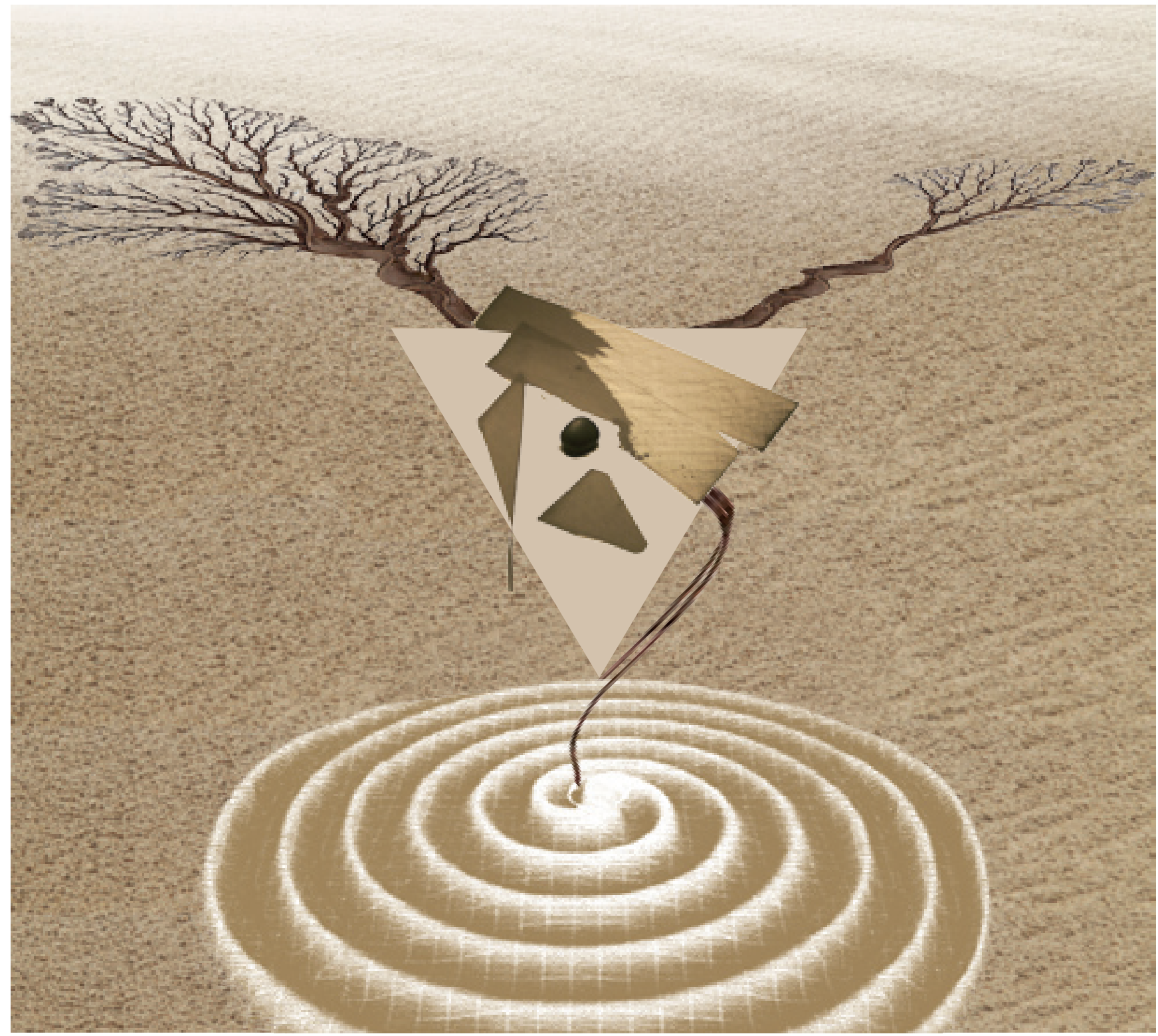

Выбор приоритетных направлений и перспективных технологий - ключевая задача научно-технической и инновационной политики. При наличии общих принципов практика их установления характеризуется существенными межстрановыми различиями.

Сопоставляя опыт развитых и развивающихся государств (на примере Украины), автор приводит рекомендации по совершенствованию механизма отбора приоритетов и, как следствие, инновационной политики в целом.
* Румпф Гудрун - руководитель проекта, Департамент информационно-коммуникационных и консалтинговых услуг, INTRASOFT International (Люксембург).

E-mail: Rumpf.Gudrun@gmail.com

Адрес: 2b rue Nicolas Bov, L - 1253 Luxembourg

Ключевые слова

установление приоритетов; инновационная политика; реализация политики; целевые приоритеты; тематические приоритеты; функциональные приоритеты; мониторинг; экспертиза.

Статья подготовлена в рамках проекта «Enhance Innovation Strategies, Policies and Regulation in Ukraine», выполненного в $2009-2011$ гг. при поддержке Еврокомиссии. Исследование было направлено на идентификацию ключевых факторов, стимулирующих либо сдерживающих развитие инновационной деятельности на Украине, и выработку рекомендаций по комплексу мер, обеспечивающих переход Украины к конкурентоспособной экономике, основанной на знаниях. 


\section{Механизм формирования приоритетов инновационной политики}

\section{Эволюция практики установления приоритетов}

В технологической и инновационной политике промышленно развитых стран традиционно уделяется серьезное внимание поддержке исследовательских направлений, технологий и секторов, способных внести существенный вклад в решение социальноэкономических задач. Таким образом, установление приоритетов (priority setting) технологического развития изначально относится к ключевым элементам политики. Эта деятельность имеет, как минимум, три аспекта [Gassler et al., 2008]:

- Тематический. Выявляются актуальные сферы (технологии и области деятельности), требующие первоочередного государственного вмешательства.

- Институииональный. Определяютсяпорядоки критерии отбора приоритетов, поддерживаемых политическими институтами.

- Легитимационный. Политики и другие ключевые акторы аргументируют предпринимаемые действия и итоговый выбор приоритетов.

В эволюции определения приоритетов инновационной политики выделяют четыре последовательно развивавшихся подхода:

- Традиционный иелевой (mission-oriented) (19401950-е гг.). Ориентируется на потребности в наращивании военного технологического преимущества.

- Основанный на приоритетах промышленной политики (с 1960-х гг.). Характеризуется более широким охватом и акцентируется на ключевых гражданских технологиях.

- Системно-ориентированный (с 1980-х гг.). Фокусируется на основных функциональных аспектах (кооперация, сети и т. д.).

- Новый цеелевой. Связан с развитием технологий, направленных на преодоление социальных и экологических вызовов (старение населения, проблемы охраны здоровья, поддержание устойчивого развития, обеспечение безопасности).

Все отмеченные подходы с различной доминантой присутствуют в стратегиях многих стран. Так, в США по данным за 2003 г. на традиционные оборонные и космические технологии было выделено свыше 60\% общего объема финансирования исследований и разработок (ИиР). В то же время в Германии на них приходилось лишь 19\% общих расходов на ИиР, а затраты на «гражданские» статьи составили 65\% [Rammer et al., 2004].

Анализируя процесс формирования приоритетов, необходимо учитывать усложняющуюся структуру современной инновационной политики. Для большинства стран характерно отсутствие единого центрального органа, ответственного за идентификацию, выбор и установление тематических приоритетов. Как правило, в эту деятельность вовлечены различные организации и заинтересованные группы, что позволяет сочетать «директивный» подход с инициативами «снизу» ${ }^{2}$.

Одна из ключевых проблем постановки приоритетов - поиск адекватных методологий их идентификации, отбора и утверждения. С 1980-х гг. стали широко применяться такие методы, как технологическая экспертиза и технологический Форсайт. Появление и распространение радикальных инноваций, например Интернета, заставило уделять более пристальное внимание инициативам, выдвигаемым «снизу».

Сегодня развитыми странами признается нецелесообразность слишком узкого набора приоритетов. Доказано, что во многих случаях в отношении новых технологий и наиболее успешных инноваций рыночные механизмы «работают» гораздо эффективнее, чем директивные политические меры.

Осознание перспективности таких областей, как информационно-коммуникационные технологии, биотехнологии и т. п., и вышеупомянутых глобальных вызовов привело к выбору многими странами «стандартного» перечня приоритетов инновационной политики. Общим трендом становятся отказ от фокусировки на узких тематических направлениях и ориентация на «идущие снизу» (bottom up) рыночные силы. Одновременно усиливается акцент на более универсальных вопросах, связанных с функционированием инновационной системы и ее рамочными условиями.

\section{Новейшие тренды в формировании приоритетов и координации инновационной политики}

В последние годы государства усиливают горизонтальную составляющую инновационной политики с целью достичь максимальной согласованности и координации, что напрямую влияет на механизмы отбора приоритетов. Концепция третьего, новейшего поколения политики основана на предположении, что ресурсы для инноваций рассредоточены по различным секторам или областям политики, и их необходимо интегрировать.

Эффективная координация возможна при условии, что органы управления способны четко сформулировать стратегию, долгосрочную политику и ориентиры, которые аргументированно задают направления для постановки приоритетов. В противном случае этот процесс осуществляется посредством несвязанных действий на более низком уровне за счет коммуникации, консультации и арбитража [OECD, 2005a]. В этом плане сформировался ряд базовых подходов.

Так, правительства некоторых стран, стремясь сформировать всеобъемлющую повестку и соответствующий ей набор приоритетов, расширили рамки политики. Применение подобного подхода затрудняется тем, что он требует сотрудничества различных акторов, а потому может противоречить сложившейся практике разделения сфер ответственности отдельных министерств и ведомств.

Другие государства, корректируя и легитимируя политические приоритеты, прибегли к реструктуризации институтов научно-технической и инновационной сферы, часть которых были объединены и переименованы. 
Широкое распространение получили попытки разработки более разносторонней и в то же время сконцентрированной на конкретных задачах политической повестки. Для этого практикуется создание различных консультативных и координационных органов по вопросам научно-технической и инновационной политики (например, советов) или «инновационных платформ». Подобные механизмы, как правило, выходят за пределы традиционных сфер и оперируют смешанным набором формальных, полуформальных и неформальных координационных мер [Cunningham, Karakasidou, 2009].

Координация политики и реализация ее приоритетов представляют серьезный вызов для многих стран. Министерства все реже справляются с обеспечением растущих требований к координации, что в последние десять лет привело к развитию т. н. «агентизации» (agencification) [OECD, 2005a]. При таком подходе сохраняется базовая политическая структура правительства, вместе с тем на уровне ведомств стимулируются децентрализация, подотчетность и гибкость. Считается, что координация в рассматриваемой сфере наиболее эффективна при наличии ведомств, обладающих оптимальными ресурсами для взаимодействия с инноваторами.

\section{Определение приоритетов инновационной политики в странах ЕC}

Процедуры отбора приоритетов и их эффекты характеризуются значительным межстрановым разнообразием, как следствие, правительства многих стран находятся в поиске лучших практик. Подобная вариативность инструментов и институтов обусловлена, прежде всего, различиями национальных культур и историческими предпосылками. Зачастую, несмотря на единство базового подхода, негибкость институциональных структур ведет к зависимости от предшествующего развития (path dependency) и, как следствие, разным порядкам утверждения приоритетов. Тем не менее доминирование концепции «национальных инновационных систем» способствует объединению руководящих принципов политики [Gassler et al., 2004].

Установление приоритетов не является исключительной функцией общегосударственного уровня. За него в равной степени ответственны индивидуальные финансирующие органы, исследовательские организации, университеты и другие ключевые акторы инновационной системы [Gassler et al., 2004]. В связи с этим усложняется ключевая задача - обеспечение согласованности между разными стратегическими уровнями и субъектами, что требует четкого и прозрачного разграничения полномочий отдельных организаций.

При том что универсальной практики, обеспечивающей оптимальную централизацию либо децентрализацию постановки приоритетов, не существует, тем не менее можно выделить несколько общих принципов. Как правило, в «сферу компетенций» национального уровня входят:

- определение места инноваций в системе приоритетов политики (что отражается в объемах бюджета, выделяемых на ИиР);
- регулирование общесистемных факторов (прав интеллектуальной собственности, поддержки малого и среднего бизнеса, регламентации различных видов деятельности);

- идентификация базовых функциональных и тематических приоритетных областей, связанных с решением социальных проблем (экология, здоровье и т. п.), компенсацией «провалов рынка» или восполнением пробелов в национальной инновационной системе.

Задача посреднических организаций (финансирующих ведомств, институтов трансфера технологий и т. п.) и субъектов ИиР (университетов, исследовательских центров, предприятий) — трансформировать обозначенные стратегические приоритеты, направив их в практическую плоскость [Gassler et al., 2004].

Как упоминалось выше, в настоящее время выделяются три типа приоритетов инновационной политики: целевые, функциональные и тематические. К первому относятся различные целевые ориентиры, например достижение уровня затрат на ИиР в размере 3\% от общеевропейского ВВП, базовые приоритеты программы ЕС по исследованиям, технологическому развитию и инновациям (Research, Technology Development and Innovation, RTDI) или интернационализация последних. Второй подразумевает развитие определенных функций национальной инновационной системы финансирование научной деятельности, мобильность исследователей и т. п. Примером может служить недавно принятая Национальная инновационная стратегия Финляндии, рассматривающая в качестве основного инструмента стимулирования фирм к инновациям увеличение инвестиций в корпоративные ИиР. Тематические приоритеты связаны с определенными технологическими направлениями или областями бизнеса, такими как нанотехнологии, инновации в сфере услуг, экологические инновации и др.

Зачастую приоритеты образуют многоуровневую систему. Ее вершину образуют расширенные политические цели, которые конкретизируются комплексом тематических или функциональных мероприятий и схем финансирования, имеющих собственные приоритеты.

Порядок установления приоритетов во многом зависит от иерархического положения отвечающих за эту деятельность институтов. Правительственные «белые книги» (white papers) и инновационные стратегии обычно носят обобщенный характер и акцентируются преимущественно на целевых и функциональных приоритетах. С другой стороны, в фокусе специализированных ведомств находятся, прежде всего, тематические приоритеты, хотя задачи системного и функционального плана также не остаются без внимания.

Значительное разнообразие присуще и характеру самого процесса формирования приоритетов. Он может быть директивным либо инициированным «снизу», вовлекать широкий круг заинтересованных сторон или же осуществляться ограниченной группой экспертов. Наряду с этим существенной вариативностью характеризуются степень формализации определения приоритетов и процедуры их экспертизы. 


\section{Механизмы и инструменты реализации приоритетов}

В общем случае, многочисленные механизмы, практикуемые правительствами европейских стран для имплементации тех или иных приоритетов, носят стратегический либо операциональный характер. Стратегические приоритеты претворяются в жизнь главным образом в форме политических программ, советов, платформ, а также посредством различных специализированных органов. На операциональном уровне применяются следующие взаимосвязанные механизмы вертикальной координации и реализации приоритетов:

- финансово-бюджетные меры;

- тематические конкурсы;

- управление по результатам (performance management);

- кооперационные соглашения;

- новые инициативы и механизмы поддержки;

- рамочные программы;

- косвенное стимулирование.

Наиболее традиционная и распространенная форма инновационной политики - планирование бюджета и выделение средств на воплощение определенных приоритетов. Она является элементом практически всех механизмов и инструментов реализации приоритетов поскольку заметная их часть основана на государственном финансировании. Бюджетные меры также служат важнейшим имплементационным механизмом верхнего уровня. Даже наиболее совершенные инновационные стратегии и планы терпят крах, если не заручатся поддержкой со стороны министерства финансов и не получат необходимой «подпитки» из государственного бюджета.

За последние два десятилетия практика государственного управления во многих странах существенно изменилась. Большую роль в этом плане сыграли идеи «нового государственного управления» (new public management, NPM) и «управления по результатам», благодаря которым в государственном секторе получили распространение управленческие модели, характерные для бизнеса. Все более пристальное внимание стало уделяться эффективности практических мер, усилению подотчетности и оценке результатов на основе целевых ориентиров и индикаторов производительности. В некоторых случаях управление сфокусировано скорее не на достижении количественных показателей, а на развитии диалога министерств с соответствующими ведомствами и институтами.

К вертикальным координационным механизмам, обеспечивающим имплементацию политических приоритетов, относятся соглашения о результатах деятельности (performance agreements), контроль их исполнения и финансовая поддержка на уровне министерств. Подобные соглашения служат инструментом определения количественных и качественных ориентиров и, как следствие, концентрации ресурсов на реализации ключевых приоритетов, относящихся к сфере их деятельности.

На операциональном уровне приобрело популярность тематическое конкурсное финансирование. Конкурсы могут быть связаны не только с определен- ной научной или технологической областью (например, нанотехнологии, лесной сектор), но и более «системными» вопросами, такими как финансирование ИиР, осуществляемых малыми и средними предприятиями, или даже государственные закупки. Конкурсный принцип способствует концентрации государственных средств на наиболее перспективных проектах ИиР или иных инновационных мероприятиях.

Если имеющаяся научно-инновационная инфраструктура не обеспечивает реализации определенного приоритета, может потребоваться создание принципиально новых институтов или инструментов финансирования.

В современных условиях наблюдается постепенный переход от тематических перманентных структур поддержки ИиР к ограниченным временными рамками программам, которые при этом открыты для более широкого круга акторов. Программы - более гибкий инструмент политики (их легко инициировать и, при необходимости, свернуть), в отличие от организаций, которые склонны демонстрировать высокое внутреннее сопротивление, несмотря на то что приоритеты с течением времени меняются [Gassler et al., 2008]. В некоторых странах программы ИиР управляются отраслевыми министерствами, однако в большинстве государств эта функция возложена на специализированные ведомства.

Помимо механизмов прямого действия, следует отметить многочисленные «белые книги» и стратегические документы, которые все активнее используются государственным сектором в качестве «стратегических сигналов» или «дорожных карт», а также частными игроками, помогая им идентифицировать свою роль и получить поддержку от государства [Cunningham, Karakasidou, 2009]. Ключевыми условиями являются наличие долгосрочной стабильности и возможность активного участия заинтересованных сторон в осуществлении стратегических процессов. Повышение предсказуемости политики, информированности о ключевых задачах стратегий и политических инициативах может в долгосрочной перспективе оказать косвенный эффект на поведение различных заинтересованных сторон.

\section{Механизмы оценки приоритетов и их реализации}

При оценке приоритетов и их реализации применяются различные процедуры мониторинга и экспертизы, охватывающие международный, национальный или региональный уровни. Под экспертизой в общем случае понимается оценка степени актуальности, результативности и эффектов той или иной меры сквозь призму ее задач, включая анализ процедур, хода реализации и административного управления. Экспертиза должна осуществляться с максимальной системностью и объективностью, причем ее охват и методы зависят от поставленных вопросов и характера рассматриваемой меры. Она может основываться на ретроспективных (ex-post), текущих или прогнозных (ex-ante) оценках, а полученная на ее основе информация - использоваться при анализе ранее предпринятых политических шагов, мониторинге действующих инициатив либо 
перспективном планировании инновационной и технологической политики. Экспертиза, базирующаяся на прогнозах, обычно служит для оценки ожидаемого эффекта от претворения в жизнь запланированных приоритетов и соотнесения поставленных количественных ориентиров с исходной ситуацией. Ретроспективная экспертиза, в свою очередь, применяется при анализе реализации приоритетов.

Методы и практики оценки приоритетов развивались параллельно с эволюцией технологической и инновационной политики по мере изменения представлений об инновационных процессах. Изначально доминировавшая в послевоенный период модель фокусировалась на оценке качества ИиР, а основными инструментами служили рецензирование и библиометрические методы. Позднее все более широкое распространение правительственных инициатив по поддержке промышленных инноваций обусловило актуальность оценки программ [Papaconstantinou, Polt, 1997].

В целом, несмотря на наличие многочисленных руководств, разрабатываемых Еврокомиссией для обеспечения единообразия в методах экспертизы, ее конкретные практики даже в масштабах Европы далеки от унифицированности. Они характеризуются разной степенью зрелости, существенной вариативностью используемых инструментов, вовлеченных институтов и роли экспертизы в общей системе политики. По этой причине важно, чтобы экспертизой учитывались сильные стороны национальных инновационных систем во всем их многообразии, что позволит выработать систематические практики оценивания приоритетов и «встроить» их в процесс формирования политики. Опыт отдельных стран свидетельствует, что процедуры мониторинга и экспертизы должны разрабатываться в привязке к политике или ее отдельным инструментам и программам, подлежащим оценке. Только заблаговременное планирование обеспечит сбор необходимых данных, согласование процедур и критериев оценки всеми заинтересованными сторонами.

Не менее важно повысить информированность руководителей высшего политического звена об экспертизах, проводимых в отношении различных стратегий и выбранных приоритетов. Действенный способ обеспечить влияние результатов экспертизы на будущую политику - сделать их предметом общественных дискуссий, в таком случае игнорировать экспертные выводы станет гораздо сложнее. Экспертиза, кроме того, должна ориентироваться на пользователя, поскольку призвана удовлетворить информационные запросы акторов, ответственных за управление стратегиями и их реализацию (политиков, компаний, координаторов программ и т. п.).

Выделяются стратегическая (системная) экспертиза и программная (институциональная). На первом уровне анализируются общий политический контекст и содержание перечня приоритетов в целом. На втором - исследуются разнообразные механизмы их имплементации (программы, институты развития и т. п.) либо организации-участники (исследовательские ин- ституты, университеты и др.); оценивается результативность тех или иных инструментов, механизмов и организаций исходя из поставленных перед ними задач в контексте выбранных приоритетов.

C точки зрения политики оба указанных типа экспертизы преследуют разные цели. Во-первых, она применяется для оценки результативности мер и инструментов политики через призму соотношения затрат и эффектов. Во-вторых, экспертиза выступает источником информации для последующего совершенствования политики.

\section{Выбор и экспертиза приоритетов: европейская практика}

Недавно проведенный в масштабе ЕС анализ практики экспертного оценивания приоритетов свидетельствует о том, что оно стало неотъемлемым элементом инновационной политики, прежде всего на практическом уровне - программ, мер и т. д. [Edler et al., 2010]. Выявлено, что примерно в половине случаев в бюджете на реализацию мер политики заложена статья затрат на экспертизу, а в двух третях случаев оценивание является частью самих мер. Общим правилом стала передача полномочий на проведение экспертизы сторонним оценщикам. Их отбор обычно осуществляется в ходе открытых тендеров.

Однако, как показал анализ, с точки зрения перемен в политике эффекты экспертизы достаточно ограниченны. Радикальные последствия, такие как закрытие программ, происходят редко и являются скорее результатом волевых политических решений. Как правило, по итогам экспертизы осуществляются незначительные изменения в содержании мер или осваиваются новые инструменты, а чаще всего действующие программы пролонгируются и расширяются.

На практике общесистемный уровень подвергается экспертизе гораздо реже, чем программы ИиР. Хотя при этом рассматриваются внешнее влияние предпринятых мер и их вклад в реализацию установленных приоритетов, подобные исследования, чаще всего, не представляют ценности для характеристики общеполитических целей и оценки адекватности выбранных приоритетов.

Успешный пример страны, имеющей давние традиции стратегических оценок инновационной политики и структурированную систему мониторинга операциональной деятельности, являет собой Великобритания. Мониторинг и экспертиза изначально предусмотрены в широком спектре видов инновационной деятельности. В 2007 г. тогдашний Департамент инноваций, университетов и компетенций (Department for Innovation, Universities and Skills, DIUS) ${ }^{3}$ взял на себя общую ответственность за все инновационные процессы на национальном уровне. В практическом плане это означало, что DIUS готовит ежегодный доклад по инновациям, в котором детализируется деятельность ведомств, связанных с этой сферой. Учитывая широкий взгляд британских политиков на инновации, такая активность может стимулироваться целым комплексом инструментов. Доклад задуман как документ, где в си- 
стематизированном виде приводится информация обо всех государственных инициативах, способствующих развитию инновационной деятельности в стране - в плане как поддержки инноваций, так и внедрения инновационных практик в работу самих департаментов [Cunningham, Rigby, 2009].

Экспертиза имеет не менее солидную документаль ную основу, будучи подкреплена различного рода ру ководствами (guides). Последние, например «зеленая книга» (green book) и «пурпурная книга» (magenta book), дают экспертам практические инструкции по оцениванию политических мер. Любая экспертиза проводится сторонними оценщиками на контрактной основе. В большинстве случаев она осуществляется с определенной периодичностью и редко носит ретроспективный характер (прежде всего потому, что многие инициативы - долгосрочные и не имеют фиксированной даты завершения). Основные условия, которым должны удовлетворять экспертные рекомендации - реалистичность и экономическая целесообразность [ там же].

С проведением оценивания также связаны серьезные вызовы. В частности, в Австрии подобная деятельность приобрела значительные масштабы, но вместе с тем усиливается критика по поводу отсутствия механизмов, призванных обеспечить обратную связь результатов экспертизы с выработкой политики. Это в очередной раз доказывает: развитая практика пересмотра приоритетов инновационной политики сама по себе не является достаточным условием; необходимо четко определить место экспертизы в структуре политики и ее реализации.

Наглядный пример реального вклада оценки в освоение новых инструментов политики демонстрирует Германия. Здесь практикуются разнообразные формальные экспертные методы, такие как фокусгруппы или семинары. Результаты экспертизы активно обсуждаются в правительстве, что свидетельствует об освоении властью новых инструментов. Однако обучение на подобных методах имеет эффект лишь для исполнения самих оцениваемых мер и значительно реже - применительно к постановке приоритетов и формированию программ на будущее. Следует подчеркнуть, что в последнем случае успех в использовании результатов экспертизы требует большей открытости и партисипативности.

\section{Опыт реализации стратегических документов}

\section{Австрия: Национальный план по исследованиям и инновациям}

Создание в 2002 г. Совета по исследованиям и технологическим разработкам (Council for Research and Technological Development) стало значимым шагом в направлении повышения четкости и прозрачности стратегического планирования в Австрии. Деятельность нового органа началась с разработки Национального плана по исследованиям и инновациям (National Research and Innovation Plan, NaFIP), ставшего опорной точкой для научно-технической и инновационной политики. В отличие от ранее изданных «белых книг», носивших рекомендательный характер и, по мнению экспертов, не оказавших ожидаемого влияния на политический процесс, Национальный план приобрел существенное практическое значение. Благодаря его публикации Совет получил возможность влиять на распределение государственного финансирования.

В документе приводился обзор ключевых индикаторов ИиР и институциональной системы Австрии с использованием международных сопоставлений. На этой основе были сформулированы предложения по научно-технической и инновационной политике, направленные на достижение национальной доли расходов на ИиР в размере $2.5 \%$ ВВП. Рекомендации касались структурных реформ отдельных секторов в целях повышения результативности выполняемых в них исследований и разработок, а также реорганизации системы финансирования науки. Кроме того, были выработаны сценарии использования средств государственного и частного секторов [Austrian Council, 2002]. Упомянутые рекомендации стали ключевым руководством по разработке государственной политики и ее реализации. Некоторые из них, в том числе рекомендации по реорганизации ведомств, финансирующих ИиР, и увеличению расходов на эту деятельность, удалось воплотить в полной мере. Однако процесс концентрации компетенций, последовательного и непротиворечивого распределения ответственности растянулся во времени.

Стремление отделить стратегический уровень от практического в австрийской инновационной системе свидетельствует об определенном прогрессе в плане делегирования министерствами все большего количества программ специализированным агентствам, в то время как меры стратегического уровня остались в ведении самих министерств и Совета. Тем не менее попрежнему сказывается недостаток четкости в определении компетенций и тематики работ, а остающееся довольно высоким общее число программ затрудняет их координацию.

В отличие от других стран, где значимую роль в дизайне программ играют специализированные агентства, в Австрии эта функция в целом остается за министерствами, что затрудняет их выполнение. Наряду с этим нельзя не учитывать и весомую роль провинций в распределении властных полномочий. Во многих случаях, участвуя в научно-технологической кооперации, они должны вносить определенные суммы из собственных бюджетов в соответствующие фонды. Необходимость дискуссий с регионами по этому вопросу приводит к тому, что запуск отдельных инициатив нередко затягивается.

\section{Национальная инновационная стратегия Финляндии}

Финляндия традиционно считается одной из ведущих стран в формировании экономики, основанной на науке и инновациях. Хотя эти сферы входят в число национальных приоритетов уже на протяжении длительного времени, переход от схемы с раздельной научной и инновационной политикой (доминировавшей в 1980-е гг.) к новой концепции интегрированной политики происходит постепенно.

В то же время на смену линейной модели инноваций приходит более интерактивная, основанная на взаимодействии. С начала 1990-х гг. базой для политических дискуссий служит концепция «национальной иннова- 
ционной системы», которая развивается и адаптируется в целях более эффективного удовлетворения потребностей субъектов ИиР, особенно частного сектора.

Приоритеты в Финляндии устанавливаются в правительственных программах и долгосрочных рекомендациях, которые готовит Совет по научной и инновационной политике (Research and Innovation Policy Council).

Инновационная стратегия, принятая Министерством занятости и экономики Финляндии (Ministry of Employment and Economy, MEE) в 2008 г., задает основные направления национальной инновационной политики. Она опирается на «расширенное определение инноваций в технологическом секторе, бизнесе и сфере услуг, а также вопросы, связанные с реализацией потенциала регионов» [MEE, 2008].

Процесс подготовки стратегии, начатый в 2007 г., носил открытый характер и основывался на мнениях экспертов, заинтересованных сторон и граждан, высказанных в ходе очных семинаров и Интернет-опросов. Опираясь на их итоги, управляющая группа подготовила предложения по стратегии, которые фокусировались на вопросах, требующих тщательного учета и анализа при формировании будущей национальной инновационной политики, и ее основных стратегических линиях. Исходя из этого, Министерство занятости и экономики подготовило государственный доклад по инновационной политике, который в 2008 г. был утвержден Правительством Финляндии.

Для содействия реализации Стратегии в 2009 г. проводилась международная экспертиза национальной инновационной системы. Эксперты представили рекомендации, соответствующие положениям Стратегии, на базе которых правительство инициировало ряд проектов и мероприятий, осуществляемых посредством специальных программ. Обычно в них участвуют несколько организаций, но основная ответственность возложена на Министерство занятости и экономики. Последнее готовит ежегодный документ «Повестка и приоритеты инновационной политики» («Innovation policy agendas and priorities»), в котором освещаются проблемы, лежащие в сфере ответственности министерского департамента по инновациям. В нем, помимо общих стратегических задач и установок, рассматриваются приоритеты правительства, программа действий и бюджет на текущий год. Документ носит открытый характер, о нем осведомлены все организации, относящиеся к сфере ответственности Министерства.

Анализ финского опыта позволяет заключить: необходимы постоянная связь между разными отраслевыми органами и привязка стратегии к стандартным управляющим механизмам, таким как ежегодные межведомственные соглашения о результатах деятельности.

\section{Формирование и реализация приоритетов инновационного развития Украины}

Украина имеет определенный опыт отбора приоритетов в научно-технологической и инновационной сфере. Первым регулирующим документом в этом направлении стал закон «Об основах государственной политики в сфере науки и технологий» (1991 г.), где декларируется, что «государство поддерживает развитие науки как ключевого источника экономического роста и неотъемлемой части национальной культуры и образования. Оно создает необходимые предпосылки для реализации инновационного потенциала граждан Украины в сфере науки и технологий; обеспечивает применение украинских и мировых научных достижений для решения социальных, экономических, культурных и иных проблем».

Согласно статье 3 данного закона центральным приоритетом для государства является поддержка исследовательских проектов, способствующих решению наиболее важных проблем развития Украины. Базовым принципом отбора проектов и концентрации ресурсов для их осуществления является формирование научно-технических приоритетов, процедура установления и реализации которых детально прописана в статье 13. Основой для определения приоритетов должен служить комплексный прогноз социальноэкономического и научно-технологического развития Украины. Обязательно наличие детального анализа различных сценариев. Перечень приоритетов подлежит одобрению парламентом, а правительство должно их реализовывать в рамках государственных научнотехнических программ.

На практике, как выясняется, приоритеты были приняты без проведения предварительных аналитических и прогнозных исследований. Получив предложения от Государственного комитета по науке и технологиям, Кабинет министров представил их в парламент.

Большинство проектов, включенных в государственные научно-технические программы, выглядели значимыми и многообещающими. Вместе с тем многие из них пересекались по тематике, что было вызвано стремлением сохранить все компетентные научные школы и поддерживать их как широкий спектр перспективных научных проектов.

Излишне «масштабная» формулировка приоритетов привела к тому, что по характеру они оказались не целевыми, а скорее - координационными, выступая инструментом совершенствования межведомственного взаимодействия. В отдельных случаях, несмотря на ограниченные объемы финансирования, направляемые на реализацию программ, им все же удалось стать «центрами кристаллизации», концентрирующими материальные и кадровые ресурсы из разных источников, что позволило достигнуть определенных практических результатов. Например, были разработаны уникальные батареи для бронетанковой техники, высокоэффективные технологии высокоточной сварки тонкостенных каркасных конструкций для воздушных лайнеров, измерительное оборудование для таможенного контроля грузов и многие другие технологии. Тем не менее с 2007 г. Министерство финансов прекратило выделение средств на государственные научно-технические программы.

С момента обретения независимости в 1991 г. на Украине менялись президенты, правительства и парламенты. Однако тенденция неадекватного финансирования научно-технологических приоритетов, 
установленных парламентом, сохранялась. Финансирование государственных программ постоянно сокращалось. Парламент в очередной раз объявлял о необходимости развивать инновационную экономику, устанавливал законы, а Национальный совет безопасности принимал резолюции. Изначально реализация приоритетов считалась ключевой задачей Министерства науки и образования, но со временем она перешла в разряд второстепенных.

Скудность финансирования иллюстрирует следующий пример. В 2004 г. средний объем средств, выделяемых на научно-технический проект, составлял примерно 55 тыс. гривен, что эквивалентно 5200 евро. Финансирование «приоритетных» проектов составляло в среднем 20 тыс. гривен (около 1900 евро).

Другой пример подчеркивает практическую незначимость научных приоритетов: в 2001 г. появился новый приоритет «Поисковые исследования в ключевых областях естественных, социальных и гуманитарных наук». Однако в его рамках не было предусмотрено научно-технологических программ, и Государственный фонд фундаментальных исследований Украины на протяжении нескольких лет недофинансировался. Фактически, введение указанного направления в состав научно-технологических приоритетов оказалось ни к чему не обязывающим, символическим знаком.

До 2002 г. в качестве одного из приоритетов научно-технологического развития рассматривалась поддержка инноваций. В свою очередь, украинский закон «Об инновационной деятельности» (2002г.) регламентировал конкретные приоритетные направления в этой области. Была разработана методология классификации приоритетов, причем каждый уровень иерархии предусматривал соответствующие механизмы реализации. На эту методологию отчасти опирается еще один закон - «О приоритетных областях инновационной деятельности» (2003г.), предусматривающий идентификацию стратегических и краткосрочных приоритетов. Первые должны носить долгосрочный характер (горизонт - свыше 10 лет), фокусироваться на важнейших сферах инновационной деятельности, обеспечивающих социальноэкономическое развитие, и разрабатываться на основе прогноза глобальных трендов социальноэкономического и научно-технологического развития с учетом инновационного потенциала Украины. Вторая категория приоритетов устанавливает направления инновационной реструктуризации промышленности, сельского хозяйства и сферы услуг с целью внедрения наукоемких продуктов, конкурентоспособных на локальных и глобальном рынках, намеченных к реализации в ближайшие 3-5 лет. Кроме того, закон предусматривает установление среднесрочных приоритетов на национальном, отраслевом и региональном уровнях.

В перечень стратегических приоритетных областей инновационной деятельности, принятый украинским парламентом на период 2003-2013 гг., входят:

- модернизация электростанций;

- новые и возобновляемые источники энергии;

- новые ресурсосберегающие технологии;
- развитие машиностроения и производства инструментов как основа технологической модернизации всех отраслей промышленности;

- высокотехнологичная металлургия;

- нанотехнологии, микроэлектроника, информационные технологии, телекоммуникации;

- совершенствование химических технологий, новые материалы, биотехнологии;

- технологическое развитие сельского хозяйства и обрабатывающей аграрной индустрии;

- строительство и реконструкция транспортных систем;

- охрана здоровья и окружающей среды;

- формирование культуры инноваций в обществе;

- развитие воздушного и водного транспорта, производство оборудования и компонентов для транспортных средств всех типов, разработка и реализация новых технологий их производства и сборки (последний пункт был добавлен в результате принятия поправок к указанному закону в 2007 г.).

Для каждой из перечисленных предметных областей были предусмотрены среднесрочные приоритеты (ст. 8 закона). Однако в 2007 г. они истекли и не получили одобрения со стороны украинского парламента на следующий пятилетний период.

Центральным пробелом в законе стало отсутствие координационных механизмов и ответственных исполнителей. Если приоритеты научно-технологического развития устанавливают общую структуру государственных программ и реализация последних прописана в законе, который регламентирует бюджетное финансирование, то инновационные приоритеты, напротив, носят рекомендательный характер и на практике оказались проигнорированными. В подобных условиях процедуры установления приоритетов потеряли свою значимость, поскольку не были четко обозначены объемы государственной поддержки и органы, ответственные за их имплементацию.

Таким образом, проект закона «О приоритетах научно-технологического развития», подготовленный Министерством науки и образования Украины и представленный парламенту в 2007 г., стал еще одним примером неэффективной постановки приоритетов. Вместо прописывания конкретных приоритетных направлений в законопроекте в очередной раз излагались государственные обязательства по поддержке науки, задекларированные в Конституции Украины (ст. 54, п. 3) и законе «О науке и научно-технической деятельности» (ст. 31, 34). Такие «приоритеты» не способны изменить ситуацию и никого ни к чему не обязывают. Как следствие, Парламентский комитет по науке и образованию заявил, что не имеет смысла одобрять предложенный перечень приоритетов. Несмотря на возражения, парламент одобрил законопроект, поставив условие, что для его реализации будет создана специальная комиссия. Однако никаких значимых модификаций внесено не было. После внесения незначительных правок законопроект вновь был рассмотрен Верховной Радой в 2009 г. Годом позднее на веб-сайте украинского парламента были опубликованы комментарии к законопроекту, подготовленные Главным научно-экспертным 
управлением, в которых говорилось, что он направлен на то, чтобы лишить парламент ряда важных полномочий, предусмотренных Конституцией. Аналогичного мнения придерживалась Национальная академия наук.

В ходе выполнения Государственной программы прогнозирования научно-технологического и информационно-технологического развития на 20042006 гг. проводилось Форсайт-исследование, основанное на опросе Дельфи, в котором приняли участие свыше 700 экспертов из сферы науки и промышленности. Научно-технический комитет программы определил 15 тематических областей. По каждой из них были назначены научный руководитель и головной исследовательский институт, включая Национальную академию наук, Украинскую академию сельскохозяйственных наук, Академию медицинских наук и три университета. Министром науки и образования и президентом Национальной академии наук были созданы органы контроля реализации программы - Совет по науке и технологиям и Секретариат программы, определен их состав, подготовлены предложения по вышеупомянутой системе научно-технических и инновационных приоритетов, сформирована постоянно действующая система прогнозирования. Результатом проведенных работ стал отбор 14 критических энергосберегающих технологических проектов.

Осенью 2007 г. была принята «Государственная программа прогнозирования научно-технологического развития Украины на 2008-2012 гг.». Ее реализация возлагалась на Украинский институт научно-технической и экономической информации при Министерстве науки и образования. Приоритезация направлений инновационного развития при этом не предусматривалась, а диапазон ИиР значительно сузился: в 2008 г. затрагивалась лишь область «энергетики и энергоэффективности», в 2009 г. — «нанотехнологии и наноматериалы». Упор делался на проведение не Форсайтных, а маркетинговых исследований. Так или иначе, программа была отменена решением Кабинета министров Украины № 704 от 22 июня 2011 г. по причине реструктуризации правительства и жестких мер экономии.

\section{Заключение}

Правильный выбор приоритетов для инноваций и технологического развития на практике представляется сложной задачей. Однако существует несколько способов, позволяющих в той или иной мере решить эту проблему.

Во-первых, в условиях быстрых темпов технологических и социальных изменений следует избегать ориентации на излишне узкий спектр тематических приоритетов, иначе можно оказаться в тупике. В то же время его чрезмерное расширение ведет к потере фокуса инновационной политики. Оптимального баланса можно достичь, если государство сосредоточится на решении функциональных задач и создании рамочных условий, делегировав выбор тематических приоритетов предпринимательскому сообществу. Подобная стратегия требует иного инструментария, чем установление тематических приоритетов. Она предполагает, например, конкурсное финансирование ИиР по принципу отбора лучших исполнителей, а не принадлежности к определенному научному направлению, а также различные инструменты поддержки исследовательской деятельности в частном секторе (прежде всего, в малом и среднем бизнесе).

Другой механизм - использование программ и проектов в качестве имплементационных инструментов вместо перманентных структур и существующих организаций. Это обеспечит не только оперативное развертывание новых видов деятельности, но и их быстрое сворачивание, если выбор будет признан ошибочным.

Необходимо выстроить систему регулярного мониторинга и экспертизы, позволяющую оценивать востребованность и функциональность того или иного инструмента реализации приоритетов. Подобный подход не гарантирует защиты от неправильного выбора, но способствует быстрым переменам в политике, которая в значительной мере носит горизонтальный и межсекторальный характер. Во многих случаях он оказался эффективным при установлении управленческих практик и позволил оптимизировать процедуру постановки приоритетов для каждого актора. В указанном контексте власть оставляет за собой задачу определения системных приоритетов, которые задают общий вектор деятельности министерств, а на практическом уровне (агентства, программы) формируются более узкие тематические приоритеты. Преимущество такого подхода заключается в том, что последние устанавливаются на уровне, концентрирующем основную массу экспертных знаний о реальных технологиях либо механизмах развития. Тем самым политики высшего звена могут сосредоточиться на стратегических вопросах и избежать усложненных схем администрирования.

Существуют различные методы формирования приоритетов, включая заседания закрытых экспертных групп (советов по науке и др.), открытые консультации с заинтересованными сторонами и различные формы стратегического планирования. В большинстве стран получил распространение партисипативный подход, предполагающий вовлечение ведущих экспертов, чиновников, представителей частного сектора, высшего образования и государственных исследовательских институтов.

Постановка приоритетов является частью более сложного процесса разработки научно-технологических стратегий. Подобные практики приобретают популярность, и даже становятся обязательными, при проведении реформ государственного управления, направленных на усиление подотчетности, обеспечение регулярного мониторинга и экспертизы политики.

Важно увязать претворение в жизнь стратегических документов с текущей деятельностью. Сложность и междисциплинарный характер инновационной политики требуют, чтобы ее реализация была четкой и заранее спланированной, а координация, мониторинг и оценивание обеспечивались головной организацией. Различные акторы часто формулируют свои стратегии без четкой привязки к общей линии, что ведет к фрагментации политики.

В силу сказанного необходимо, чтобы процесс реализации управлялся субъектом, имеющим тесные связи с исполнителями (министерствами, агентствами) 
и способным воздействовать на их поведение. Механизм влияния не обязательно должен быть формальным институтом. В этом качестве могут выступать поддержка высокого уровня и ресурсы для практической реализации. Поскольку установление приоритетов носит многоуровневый характер и осуществляется различными организациями, следует обеспечить четкую связь общей стратегии с каждым из уровней.

Ввиду того что горизонтальная (межсекторальная) и вертикальная (иерархическая) координация имеют одинаковую важность, не всякая деятельность, связанная с реализацией приоритетов, может регулироваться формальными процедурами государственного управления. Таким образом, необходимо обеспечить широкую поддержку процесса заинтересованными сторонами, для чего требуются консультации с ключевыми представителями, участвующими в подготовке стратегии и отвечающими за ее осуществление. Поскольку формальное принятие решений, особенно в случае с предпринимательскими кругами, не работает, предстоит организовать их вовлечение путем заключения соглашений либо стимулирования. Эффективным механизмом, обеспечивающим участие всех сторон в тематических программах, признаны государственночастные партнерства. Иными словами, имплементация не в меньшей степени связана с координированием сетевого взаимодействия, чем с государственным управлением.

Выбор контрольных точек и целевых ориентиров помогает отслеживать и оценивать прогресс в реализации стратегических документов. Но одного этого инструмента недостаточно, о чем свидетельствует неудавшийся опыт достижения «трехпроцентной цели», поставленной Лиссабонской стратегией-2010. Не меньшую важность имеет мониторинг текущих процессов.

Кроме того, реализации приоритетов способствуют следующие факторы:

- четкие стратегические обязательства правительства, сформулированные в программном заявлении и отраженные во всех базовых документах;

- наличие специального контролирующего и координирующего органа (совета, комитета, головного министерства, департамента по науке, технологиям и инновациям и т. п.), обладающего политическим мандатом, а также формальными или неформальными координирующими полномочиями;

- единая структура горизонтальной координации;

- ресурсы для реализации, как на уровне государственного бюджета, так и на операциональном уровне;

- расширенные консультативные процессы с реальной вовлеченностью заинтересованных сторон.

Изменение приоритетов требует пересмотра сложившейся организационной структуры. Организации могут оказаться в «ловушке» прежних приоритетов, к которым «привязаны» их ресурсы и инструменты. Подобный пересмотр обычно нарушает статус-кво, сложившийся между институтами. Опыт многих стран свидетельствует, что выбор приоритетов требует совпадения ментальных установок и принятия согласованных решений участниками из самых разных сфер. Если при их формировании не учитываются органи- зационная структура, различные мнения, характер отношений, то вероятно, что даже наилучшие стратегии не будут реализованы в соответствии с изначальным планом.

Анализ практики формирования приоритетов научно-технической и инновационной политики позволяет сделать некоторые общие выводы. Украинский опыт отличается от практик других государств по ряду параметров. Первый относится к характеру процесса установления приоритетов. В ряде европейских стран он чаще всего предполагает привлечение широкого круга акторов - представителей различных заинтересованных сторон, участвующих в Форсайт-процессах либо разработке стратегий. Как правило, привлекаются эксперты из научного сообщества, промышленности и институтов развития. Другой фактор - уровень иерархии, на котором устанавливаются приоритеты. На Украине они утверждаются преимущественно в ходе парламентских процедур, тогда как в других государствах - определяются специализированными агентствами, ответственными за финансирование ИиР, которые осуществляют приоритеты более эффективно.

Следующее отличие прослеживается в имплементационных механизмах. Украина вложила значительные усилия в процесс законодательного утверждения и парламентского одобрения приоритетов, но инструментарий их претворения в жизнь, равно как и ресурсное обеспечение оказались недостаточными. В ряде стран процесс организован гораздо эффективнее: приоритеты устанавливаются ответственными органами и осуществляются с выделением необходимых финансовых средств. Плюс к этому, создается система экспертной оценки их реализации (например, программ ИиР), что способствует повышению эффективности последних.

Наше исследование показало, что научно-техническая и инновационная политика Украины делает основной упор на тематические (физическая и химическая биология, сельскохозяйственные технологии) или целевые (mission-based) приоритеты (например, энергобезопасность и модернизация машиностроения). Значительно меньше внимания уделяется функциональным приоритетам (связанным с финансированием ИиР, налоговыми льготами и др.). С другой стороны, в европейских странах акценты инновационной политики, напротив, сместились в сторону функциональных приоритетов, хотя тематические и целевые задачи также не остаются в стороне.

Инструменты постановки приоритетов, использовавшиеся на Украине последние 20 лет, получили значительное развитие (особенно в области Форсайтисследований) и во многом сопоставимы с применяющимися в Европе; гораздо меньше информации имеется в отношении механизмов мониторинга и экспертизы.

Украина располагает обширными методологическими знаниями, успешно применяемыми для установления приоритетов, в то же время отсутствует механизм, связывающий этот процесс с их реализацией, которая отличается нескоординированностью. Как следствие неадекватно учитывались экономические вызовы, а акцент ставился на сохранение авторитетных научных и технологических структур. 
Украинская инновационная система по-прежнему функционирует в порочном круге: объем производства в экономике несопоставимо низкий по сравнению с масштабами научно-инженерного сектора. Таким образом, исследования и разработки, осуществляемые, главным образом, за счет прямых грантов, сегодня в значительной мере недофинансируются и в результате оказываются малоэффективными. Итак, после 20 лет независимости Украина по-прежнему переживает потрясения и неспособна полностью капитализировать солидный образовательный, научный и промышленный потенциал.

Возможность разработки и реализации действенной стратегии технологического развития появится еще нескоро. Научные структуры многие годы испытывают дефицит финансирования и практически не способны привлекать новые кадры, что обусловлено плохими условиями труда и низкой репутацией науки. Нехватка специалистов усугубляется оттоком талантливых ученых среднего возраста - наиболее продуктивной части исследователей. Подобная ситуация уже привела к сужению тематического охвата научной деятельности, и неуклонно снижает возможности страны выполнять исследования мирового уровня в будущем. Необходимы дальнейшая реорганизация сектора ИиР и его интеграция с технологической сферой, что, с одной стороны, позволит сэкономить средства, а с другой - компенсировать неэффективность нынешних кадров. В результате ограниченные инновационные ресурсы будут сконцентрированы на лимитированном числе продуктивных проектов.

Формирование стратегии на основе инноваций приведет к радикальному сдвигу в парадигме развития Украины, приближая ее к европейской модели. Необходимой предпосылкой для движения по этому пути является разработка согласованной всеми сторонами повестки, что позволит эффективно принимать решения и координировать процесс. Решение столь серьезной задачи не возможно без соответствующего механизма установления приоритетов инновационной политики и их реализации.

Александрова В.П. (2006) Пріоритети науково-технічного розвитку та їх роль у визначенні стратегічних орієнтирів інноваційної політики // Наука та наукознавство. № 4. С. 15-21.

Андрощук Г.О., Жиляєв І.Б., Чижевський Б.Г., Шевченко М.М. (2009) Стратегія інноваційного розвитку в Україні на 2010-2020 в умовах глобалізацій них викликів. Київ: Парламентське видавництво. С. 151-202.

Малицький Б.А., Попович О.С., Онопрієнко М.В. (2008) Обгрунтування системи науково-технологічних та інноваційних пріоритетів на основі «форсайтних» досліджень. Київ: Фенікс.

Мусіна Л.А., Кваша Т.К., Березная Н.В., Євтушенко В.М., Андрощук Г.О., Ярчук А.В. (2009) Механізми державного управління науковотехнологічною сферою (світовий та вітчизняний досвід). Київ: Український Інститут Науково-технічної та економічної інформації.

Попович О.С. (2001а) Вдосконалення системи науково-технологічних та інноваційних пріоритетів в Україні // Наукові проблеми. № 2. C. $2-6$.

Попович О.С. (2001b) Роль пріоритетів у впровадженні державної науково-технологічної політики України // Наука та наукознавство. № 2. C. $65-73$.

Попович О.С. (2001c) Тенденції в реалізації пріоритетних напрямів розвитку науки і техніки в Україні // Наука та наукознавство. № 4. C. $13-21$.

Попович О.С. (2002) Стан формування цілісної системи пріоритетних напрямів розвитку науки і техніки в Україні // Проблеми науки. № 7. C. 31-35.

Austrian Council (2002) National Forschungs- und Innovationsplan. Vienna: Austrian Council.

British Council (2002) Foresight Making the Future Work for You. British System of Forecasting. Kyiv: British Council Ukraine.

Cunningham P., Karakasidou A. (2009) A Better Understanding of the Governance of Innovation Policy. Pro Inno Trendchart. Policy Brief № 3.

Cunningham P., Rigby J. (2010) Evaluation in the United Kingdom // Edler J. et al. (eds.) Understanding Evaluation of Innovation Policy in

Europe. Final Report. INNO-Appraisal. P. 283-306.

Edler J., Cunningham P., Gök A., Rigby J., Amanatidou E., Garefi I., Bührer S., Daimer S., Dinges M., Berger M., Schmidmayer J., Guy K. (2010) Understanding Evaluation of Innovation Policy in Europe. Final Report. INNO-Appraisal.

Gassler H., Polt W., Rammer C. (2008) Priority Setting in Technology Policy - Historical Development and Recent Trends // Nauwelaers C., Wintjes R. (eds.) Innovation Policy in Europe. Measurement and Strategy. Cheltenham: Edward Elgar. P. 203-224.

Gassler H., Polt W., Schindler J., Weber M., Mahroum S., Kubeczko K., Keenan M. (2004). Priorities in Science \& Technology Policy - An International Comparison. Project report commissioned by the Austrian Council for Research and Technology Development.

Loveridge D., Georghiou L., Nedeva M. (1995) United Kingdom Foresight Programme. PREST, University of Manchester.

MEE (2008) National Innovation Strategy. Finnish Ministry of Employment and the Economy.

OECD (2005a) Governance of Innovation Systems. Vol. 1: Synthesis Report.

OECD (2005b) Governance of Innovation Systems. Vol. 2: Case Studies in Innovation Policy.

OST (1996) Winning Through Foresight: A Strategy Taking the Foresight Programme to the Millenium. London: Office of Science and Technology.

Papaconstantinou G., Polt W. (1997) Policy Evaluation in Innovation and Technology: An Overview // Policy Evaluation in Innovation and Technology: Towards Best Practices (OECD Conference report). P. 9-14.

Polt W. (2006) Models of S\&T Policy Coordination and S\&T Priority Setting in Europe. Paper presented at the STEPI International Symposium "S\&T Policy Coordination System: Experiences and Prospects", Seoul, 23 October 2006.

Rammer Ch., Polt W., Egeln J., Licht G., Schibany A. (2004) Internationaler Vergleich der Forschungs- und Innovationspolitik. Aktuelle Trends und Entwicklungen in ausgewählten Aktionsfeldern. Nomos Verlag.

Rumpf G., Strogylopoulos G. (2011) Innovation Policy: European Benchmarking for Ukraine. Vol. 3. "Innovation in Ukraine - Policy Options for Action". Kiev.

Rumpf G., Strogylopoulos G., Yegorov I. (2011) Innovation Policy: European Benchmarking for Ukraine. Vol. 1 "Key Features of Innovation Policy as a Basis for Designing Innovation Enhancing Measures Leading Ukraine to a Knowledge Based Competitive Economy - Comparison EU and Ukraine". Kiev. 


\title{
Setting Priorities for Innovation Policy and Evaluating Their Performance: Evidence from Europe and Lessons for Ukraine
}

\author{
Gudrun Rumpf \\ Team Leader, Department for Infocom \& Consulting Services, INTRASOFT International (Luxembourg) \\ Address: 2b rue Nicolas Bov, L - 1253 Luxembourg
}

\begin{abstract}
$\mathrm{S}$ etting priorities for supporting prospective technologies and activities is a key issue for science, technology and innovation (STI) policy. The general principles of priority-setting practices vary significantly across countries in terms of process and outcome due to different national cultures, historical prerequisites and rigidities of institutional settings. Of ten there is a perceived gap between stated policy goals and actual implementation of policy measures. A gap is typical for many developing countries, including Ukraine, in particular. Ukraine has an established system of laws for STI as well as a solid methodological base for priority setting. Policy aims, however, are not supported by relevant implementation mechanisms, including programmes and framework conditions as well as monitoring and evaluation procedures.

The paper analyses evidences from several leading European countries and provides recommendations on

how to achieve higher performance of priority setting and thus overall innovation policy. The author concludes that relying on a too narrow definition of thematic priorities may lead to dead-ends. In contrast too broadly ranging priorities do not direct the innovation policy sufficiently. An optimal balance could be achieved if only the government concentrates more on setting general goals and targets as well as ensures necessary framework conditions and infrastructure for innovation, allowing the bottomup market forces to select thematic priorities. Besides the setting of priorities and their implementation should be delegated to committed organizations and agencies that possess all the relevant resources and competences. This ensures both vertical and horizontal policy co-ordination as well as wider stakeholder involvement into the preparation and implementation of a national innovation strategy.
\end{abstract}

\section{Keywords}

priority setting; innovation policy; policy implementation; mission-oriented priorities; thematic priorities; functional priorities; monitoring; evaluation.

\section{References}

Alexandrova V.P. (2006) Prioriteti naukovo - tehnichnogo rozvitku ta ïh rol' u viznachenni strategichnih orientiriv innovacijnoï politiki [Priorities of the Science and Technical Development and Their Role in Setting Strategic Milestones of the Innovation Policy]. Nauka ta naukoznavstvo, no 4, pp. 15-21. Androshchuk G.O., Zhylyaev I.B., Chyzhevskyy B.G., Shevchenko M.M. (2009) Strategija innovacijnogo rozvitku v Ukraïni na 2010-2020 v umovah globalizacij nih viklikiv [Strategy of Innovation Development of Ukraine for 2010-2020 in Globalization Challenges], Kiev: Parlaments'ke vidavnictvo. Austrian Council (2002) National Forschungs- und Innovationsplan, Vienna: Austrian Council.

British Council (2002) Foresight Making the Future Work for You. British System of Forecasting, Kyiv: British Council Ukraine.

Cunningham P., Karakasidou A. (2009) A Better Understanding of the Governance of Innovation Policy. Pro Inno Trendchart. Policy Brief no 3.

Cunningham P., Rigby J. (2010) Evaluation in the United Kingdom. Understanding Evaluation of Innovation Policy in Europe (eds. J. Edler et al.) Final Report. INNO-Appraisal, pp. 283-306.

Edler J., Cunningham P., Gök A., Rigby J., Amanatidou E., Garefi I., Bührer S., Daimer S., Dinges M., Berger M., Schmidmayer J., Guy K. (2010) Understanding Evaluation of Innovation Policy in Europe. Final Report. INNO-Appraisal.

Gassler H., Polt W., Rammer C. (2008) Priority Setting in Technology Policy - Historical Development and Recent Trends. Innovation Policy in Europe. Measurement and Strategy (eds. C. Nauwelaers, R. Wintjes), Cheltenham: Edward Elgar, pp. 203-224.

Gassler H., Polt W., Schindler J., Weber M., Mahroum S., Kubeczko K., Keenan M. (2004). Priorities in Science \& Technology Policy - An International Comparison. Project report commissioned by the Austrian Council for Research and Technology Development.

Loveridge D., Georghiou L., Nedeva M. (1995) United Kingdom Foresight Programme, PREST, University of Manchester.

Malytskyy B.A., Popovych O.S., Onoprienko M.V. (2008) Obsruntuvannja sistemi naukovo-tehnologichnih ta innovacijnih prioritetiv na osnovi «forsajtnih» doslidzhen [Substantiation of the System of Science, Technology and Innovation Priorities on the Basis of Foresight Research], Kiev: Phoenix.

MEE (2008) National Innovation Strategy, Finnish Ministry of Employment and the Economy.

Musina L.A., Kvasha T.K., Bereznaya N.V., Yevtushenko V.M., Androshchuk G.O., Yarchuk A.V. (2009) Mehanizmi derzhavnogo upravlinnja naukovotehnologichnoju sferoju (svitovij ta vitchiznjanij dosvid) [Mechanisms of State Governance of the Science and Technology Sphere (World and Ukrainian Experience)], Kiev: Ukrainian Institute for Scientific, Technical and Economic Information.

OECD (2005a) Governance of Innovation Systems, vol. 1: Synthesis Report.

OECD (2005b) Governance of Innovation Systems, vol. 2: Case Studies in Innovation Policy.

OST (1996) Winning Through Foresight: A Strategy Taking the Foresight Programme to the Millenium, London: Office of Science and Technology.

Papaconstantinou G., Polt W. (1997) Policy Evaluation in Innovation and Technology: An Overview. Policy Evaluation in Innovation and Technology: Towards Best Practices (OECD Conference report), pp. 9-14.

Polt W. (2006) Models of S\& T Policy Coordination and S\& - T Priority Setting in Europe. Paper presented at the STEPI International Symposium "S\&T Policy Coordination System: Experiences and Prospects", Seoul, 23 October 2006.

Popovych O.S. (2001a) Vdoskonalennja sistemi naukovo-tehnologichnih ta innovacijnih prioritetiv v Ukraïni [Improving the System of Science, Technology and Innovation Priorities of Ukraine]. Naukovi problemi, no 2, pp. 2-6.

Popovych O.S. (2001b) Rol' prioritetiv u vprovadzhenni derzhavnoï naukovo-tehnologichnoï politiki Ukraïn [Role of Priorities in Implementation of the Ukrainian State Science and Technology Policy]. Nauka ta naukoznavstvo, no 2, pp. 65- 73.

Popovych O.S. (2001c) Tendenciï v realizacii prioritetnih naprjamiv rozvitku nauki i tehniki v Ukraïni [Trends in Implementation of Priority Areas of Science and Technology Development in Ukraine]. Nauka ta naukoznavstvo, no 4, pp. 13-21.

Popovych O.S. (2002) Stan formuvannja cilisnoï sistemi prioritetnih naprjamiv rozvitku nauki i tehniki v Ukraïni [Status of Development of a Whole System of Priority Areas of Science and Technology Development in Ukraine]. Naukovi problemi, no 7, pp. 31-35.

Rammer Ch., Polt W., Egeln J., Licht G., Schibany A. (2004) Internationaler Vergleich der Forschungs- und Innovationspolitik. Aktuelle Trends und Entwicklungen in ausgewählten Aktionsfeldern [International Comparison of Research and Innovation Policy. Actual Trends and Developments in Selected Fields of Activity], Nomos Verlag.

Rumpf G., Strogylopoulos G. (2011) Innovation Policy: European Benchmarking for Ukraine, vol. 3. "Innovation in Ukraine - Policy Options for Action”, Kiev.

Rumpf G., Strogylopoulos G., Yegorov I. (2011) Innovation Policy: European Benchmarking for Ukraine, vol. 1 "Key Features of Innovation Policy as a Basis for Designing Innovation Enhancing Measures Leading Ukraine to a Knowledge Based Competitive Economy - Comparison EU and Ukraine", Kiev. 


\title{
Детерминанты продуктивности научных исследований в сфере высшего образования: эмпирический анализ
}

\author{
Дж. Джейкоб *, М. Ламари * *
}

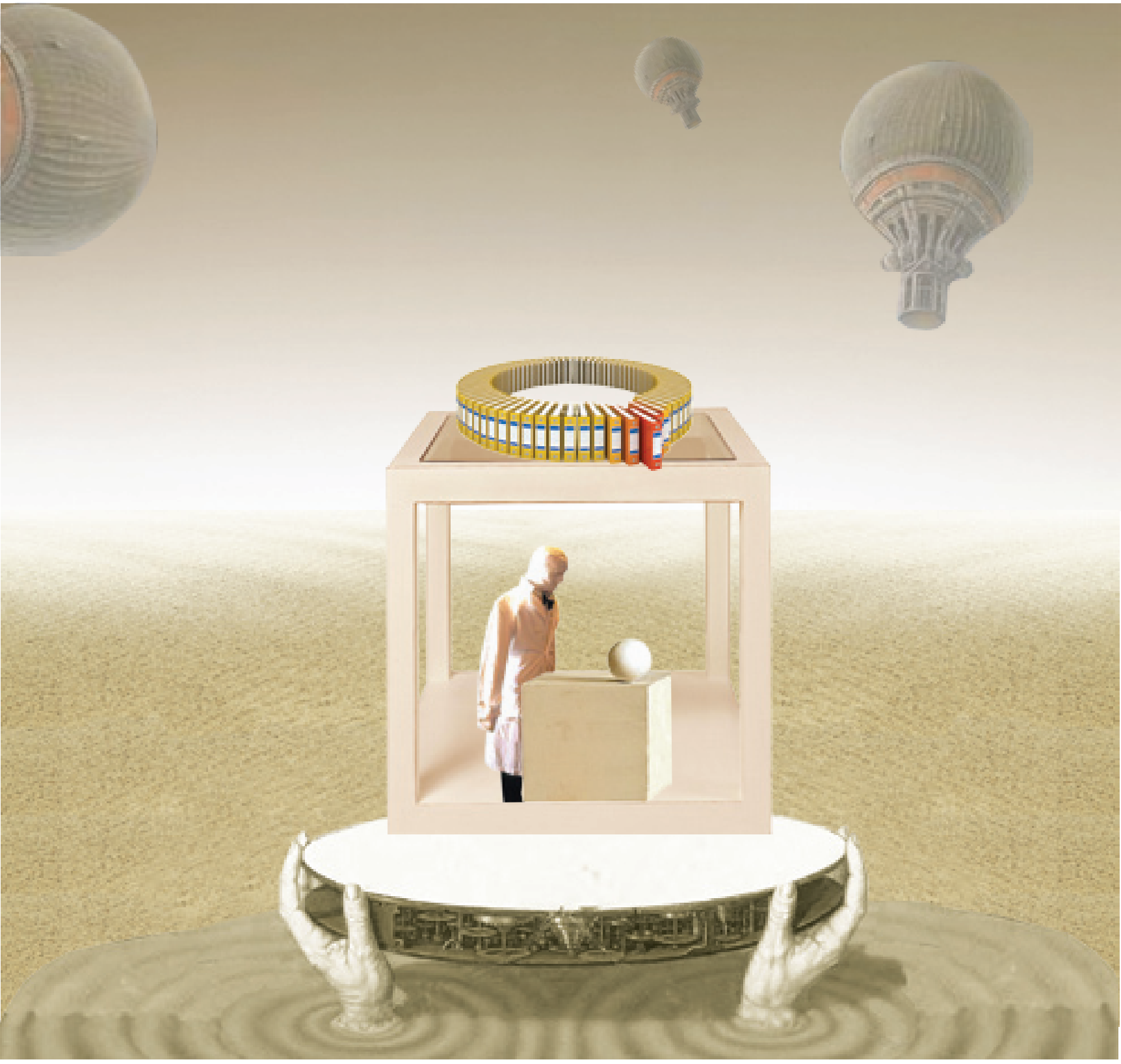

Роль высшего образования в производстве новых знаний неуклонно растет. Вместе с тем исследования продуктивности университетских ученых пока не многочисленны, хотя их результаты имеют критическое значение для научной политики.

В статье на примере канадских университетов оценивается роль разных факторов в повышении результативности исследователей: объема финансовой поддержки, ее источников, возраста и пола ученых, языка преподавания, размера учебного заведения.
* Джейкоб Джоан - менеджер по оценке проектов. E-mail: johann.jacob@enap.ca

** Ламари Моктар — директор. E-mail: moktar.lamari@enap.ca

Центр экспертизы исследований и оценки программ, Национальная школа государственного управления (Centre d'expertise et de recherche en évaluation de programmes (CREXE), École nationale d’administration publique), Университет Квебека, Канада

Адрес: 555, boulevard Charest Est, Québec (Québec) G1K 9E5

Ключевые слова

университетские исследования; библиометрические индикаторы; финансирование исследований; продуктивность ученого; оценка эффекта; импакт-фактор. 
$\Pi$ рогресс научных исследований сферы образования во многом достигнут благодаря таким ведущим ученым, как психолог Ж. Пиаже и экономист Дж. Хекман, лауреат Нобелевской премии. Их работы оказали серьезное влияние на подходы к развитию человеческого капитала; как следствие, возросли оценки эффектов, производимых вузовской наукой в отношении общественного благосостояния. Пиаже проанализировал факторы, способствующие более эффективной передаче знаний [Piaget, 1972], a Хекман - социально-экономические показатели формирования человеческого капитала, доказав, что социальные эффекты процесса обучения обратно пропорциональны возрасту учащегося [Heckman, Cameron, 2001]. Эти достижения послужили основой для дальнейших изысканий в рассматриваемой сфе$\mathrm{pe}$, а многочисленные публикации по их результатам стали аргументом в пользу выделения целевого государственного финансирования на исследования сферы образования, объемы которого постоянно росли [Edwards, 2000; Mortimore, 1999].

Тем не менее вклад университетских ученых в получение новых знаний не всегда соответствует ожиданиям [Carayol, Matt, 2006; Adams, Griliches, 1996, 1998, Mortimore, 1999]. Необходимость оптимизации расходования средств вынуждает спонсирующие организации корректировать стратегии их распределения, включая критерии финансирования вузовской науки. Соотношение расходов на научную деятельность (гранты, обеспечение инфраструктурой, подготовка кадров и т. п.) и ее результатов (продуктивность, цитирование, эффект и др.) становится стратегическим аспектом принятия государственных решений, оказывающих влияние на развитие инноваций и компетенций. Оказавшись в фокусе внимания специалистов в области оценки научной политики, продуктивность ученых была установлена в качестве критерия для государственного инвестирования в науку [Walberg et al., 1977, 1981; Smith, Caulley, 1981]. Данной теме посвящен ряд исследований, в основном в странах-членах ОЭСР - Франции [Carayol, Matt, 2006; Turner, Mairesse, 2003], CШA [Bozeman, Gaughan, 2007; Adams, Griliches, 1998], Италии [Abramo et al., 2009], Новой Зеландии [Goldfinch, 2003], Великобритании [Elton, 2000], Австралии [Marinova, Newman, 2008] и ЕС [Defazio et al., 2009].

Несмотря на изобилие эмпирических изысканий в отношении публикационной активности, лишь немногие из них оценивают ее применительно к образовательной сфере [Clark, Guba, 1976; Eash, 1983; Gordon et al., 1984; Kroc, 1984; Walberg et al., 1977; West, 1978]. При этом создается впечатление, что они ограничиваются анализом цитирования некоторых известных специалистов в данной области [Walberg et al., 1977] или компиляцией цитат из отдельных статей [Smith, Caulley, 1981; Walberg et al., 1981]. Ряд авторов попытались оценить влияние публикаций в образовательных журналах [Campbell, 1979; Campanario et al., 2006; Luce, Johnson, 1978; Mayo et al., 2006; Orr, 2004; Smart, Elton, 1981; Haas et al., 2007]. Работ, посвященных детерминантам результативности вузовских ученых, нам выявить не удалось.

На восполнение упомянутого пробела направлено предпринятое нами исследование.
Помимо идентификации факторов, определяющих продуктивность университетской науки, мы попытались оценить, насколько эффективно используются выделенные на нее средства. Анализ проводился на примере научных сотрудников университетов канадской провинции Квебек. Информационной основой служили детализированные хронологические данные о затратах на исследования и их результирующие показатели (последние измерялись с помощью библиометрических индикаторов). Мы исходили из предположения, что продуктивность исследовательских проектов в значительной степени определяется объемом и источниками финансирования.

\section{Концептуальные рамки и детерминанты продуктивности}

\section{Теоретическая основа}

Развитие практики измерений производительности научных исследований во многом обусловлено влиянием эконометрических моделей, устанавливающих на макроэкономическом уровне связь между результатами научной деятельности, экономическим ростом и улучшением благосостояния общества, включая здравоохранение, уровень доходов, качество жизни и т. д. Говоря более конкретно, с точки зрения задач нашего анализа особый интерес представляет модель, описывающая микроэкономический процесс трансформации затрат (финансовых, кадровых, организационных и др.) в измеримые продукты (например новые знания, статьи, монографии, инновации и др.). Наши рассуждения основаны на работах Дж. Адамса и Ц. Грилихеса [Adams, Griliches, 1996, 1998], приравнивающих продуктивность (с помощью известных экономической науке производственных функций, логарифмическая спецификация которых позволяет оценить коэффициенты эластичности результатов исследовательской деятельности) к затратным переменным, в частности финансовым ресурсам, человеческому капиталу (квалификация, возраст, пол, статус исследователей и т. п.) и к другим активам, связанным с научными дисциплинами или организациями (научными группами, лабораториями, кафедрами и т. д.). Линейная регрессия позволяет оценить динамику отдачи от масштаба на основе проанализированных результатов [Adams, Griliches, 1998].

\section{Методологическая основа}

Как в абсолютной, так и в динамической перспективе оценка политики позволяет судить об адекватности, эффективности и значимости государственной поддержки научной и инновационной деятельности [Marinova, Newman, 2008; Hicks et al., 2004; Abramo et al., 2009; Geuna, Martin, 2003]. В ряде стран для демонстрации эффектов исследований, выполненных за государственный счет, в отношении производства знаний, создания инноваций и распространения новых технологий используются методы оценки на основе фактических данных. При этом расходы на науку напрямую связываются с ее «продуктом». Распространена практика оценки отдачи финансирования (включая персональные, возобновляемые, смешанные гранты) с точки зрения произво- 
дительности (качества и объема научных результатов) [Adams, Griliches, 1998]. Оценка программ позволяет формализовать связи затрат, результатов и внешнего влияния в рамках логической модели и программ, выявить корреляцию между этими параметрами, которая часто формулируется в терминах связи полученных результатов с политикой государства.

Первые попытки ранжирования университетских подразделений по производительности опирались на опросы экспертов, которые выделяли лучшие, по их мнению, факультеты, кафедры и т. п. [Walberg, 1972; Cartter, 1977; Ladd, Lipset, 1979; Blau, Margulies, 1975; Sieber, 1966]. Позднее стали использоваться показатели публикационной активности - количественные (число индивидуальных и совместных статей) и качественные (например, эффект, цитирование). Наибольшее распространение при оценке авторитета ученого или публикации получил импакт-фактор [Brainerd, 2006; Campanario et al., 2006; Glanzel, Moed, 2002]. Он служит индикатором влияния той или иной работы на изданные впоследствии материалы, измеряемого числом цитирований.

Для получения более полной картины, помимо числа статей, научная производительность организации оценивается по выступлениям ее сотрудников на конференциях или семинарах; средствам, полученным от институтов, не относящихся к финансирующим организациям, и др. [Denton et al., 1986; Eash, 1983]. Дополнительными количественными характеристиками влияния исследовательских работ являются:

- уровень цитирования в расчете на публикацию;

- процент высокоцитируемых работ ученого;

- средний (медианный) импакт-фактор совокупного количества статей ученого;

- средний стандартизованный рейтинг журналов, печатающих автора;

- соотношение персонального импакт-фактора конкретного ученого либо издававших его работы журналов с медианными значениями в сфере его деятельности [Costas et al., 2010].

Для корректировки ошибок, связанных с расчетом определенных индикаторов, разработаны такие показатели как е-индекс, g-индекс, Н-индекс, уровень цитирования с учетом возраста [Ouimet et al., 2011].

\section{Детерминанты продуктивности университетских исследований}

Рассматриваемые в литературе многочисленные факторы, определяющие продуктивность научной деятельности, можно разделить на три основные категории: индивидуальные характеристики ученых, показатели финансирования и организационный контекст. Рассмотрим их подробнее, начав с первых.

Связь между возрастом и производительностью ученых неоднократно была предметом эмпирического анализа [Gordon et al., 1984; Gingras et al., 2008; Lehman, 1953]. Большинство авторов полагают, что возраст научного работника косвенно свидетельствует о его опыте и объеме накопленных знаний, однако мнения о наиболее «плодовитом» возрастном периоде расходятся. Одни считают, что это промежуток между сорока-пятьюдесятью [Lehman, 1953] или пятьюдесятью-шестьюдесятью годами [Gingras et al., 2008], отмечая, что по прохождении этого временного отрезка исследовательская производительность многих специалистов постепенно снижается; они переходят на административную работу или сосредотачиваются на повышении качества, а не на увеличении числа публикаций. С другой стороны, Р. Костас и его коллеги убеждены, что наиболее «плодотворными» являются самые молодые кадры, обосновывая это тем, что последние стремятся сделать выдающуюся научную карьеру [Costas et al., 2010].

Другой значимый фактор продуктивности пол исследователя. В работе [Levin, Stephan, 1998] отмечается, что женщины публикуются меньше, чем коллеги-мужчины. В числе причин называются: семейные обязанности, недостаточное участие в научных сетях (где доминируют мужчины) или неадекватное представительство в административных кругах, распоряжающихся бюджетами на исследования. Однако многообразие ситуаций и контекстов не позволяет получить однозначного эмпирического подтверждения тому, что женщины-ученые менее результативны, чем мужчины.

К организациионным характеристикам, определяющим результативность исследований, относят размер, репутацию и структуру университета [Broder, 1993]. Ученые в крупных, престижных университетах получают преимущества за счет позитивных экстерналий, которые стимулируют к написанию большего числа статей и достижению высоких показателей цитирования. Принадлежность к таким учебным заведениям позволяет кооперировать с известными учеными; предоставляет широкие возможности добиться издания собственных работ; дает шанс получить привилегированную, перспективную должность и, как следствие, существенно повысить свою квалификацию [Gordon et al., 1984]. Позиции англоязычных университетов в международных рейтингах по научной продуктивности зачастую выше, чем франко- или германоязычных. Отметим, что упомянутые рейтинги не всегда объективны, в частности потому, что не учитывают в достаточной степени работы на других языках, кроме английского, который доминирует в базах данных, индексирующих научные публикации.

Финансовые аспекты составляют основное содержание многих эмпирических работ [Carayol, Matt, 2006; Adams, Griliches, 1996, 1998], в которых доказывается, что производительность ученых в значительной степени определяется стратегиями и приоритетами, в соответствии с которыми спонсирующие организации предоставляют средства [Auranen, Nieminen, 2010]. Выявлено, что источники финансирования (гранты либо поддержка со стороны государственного или частного сектора) оказывают неодинаковое влияние на производственные показатели ученого. Наиболее плодовитыми являются те, кто сочетает исследования, предполагающие оплату по результатам (через гранты), с работами по государственным и корпоративным договорам [Bozeman, Gaughan, 2007].

Исходя из приведенных выше рассуждений, в качестве индикаторов, потенциально детерминирующих 
производственные показатели университетской науки, нами выбраны следующие переменные:

- персональные (возраст и пол);

- институциональные (основной язык преподавания и размеры учебного заведения);

- финансовые характеристики, в частности источники поддержки (общий объем; средства, полученные от научных фондов и советов; ассигнования со стороны федеральных и региональных органов власти; корпоративные инвестиции).

\section{Информационная база и объяснительная модель}

\section{Виды данных и их источники}

Проводя статистический анализ, мы оперировали двумя категориями данных: сведения о финансировании и библиометрические индикаторы. Информация о выделенных средствах получена из административной и статистической отчетности высших учебных заведений, интегрированной в Информационную систему по университетским исследованиям (Information System for University Research, SIRU), поддерживаемую квебекским Министерством образования, досуга и спорта (Quebec Ministry of Education, Recreation and Sports). Система ежегодно обновляется при участии администраций квебекских университетов, ответственных за организацию исследований. Библиометрические показатели взяты из системы Web of Science, индексирующей статьи более чем из 11000 научных журналов по широкому спектру дисциплин. Такие индикаторы более надежны, чем декларативные, неверифицируемые данные обследований, основанные на ответах, которые выбираются респондентами по своему усмотрению.

Дополнительным источником финансовой и библиометрической информации служила база данных Expertise recherche Québec (www.erq.gouv.qc.ca), содержащая сведения о более чем 13 тыс. ученых, работающих в учреждениях высшего образования провинции Квебека.

Как и в аналогичных исследованиях [Carayol, Matt, 2006; Adams, Griliches, 1996, 1998], ученые, входящие в выборку, отбирались по трем критериям: принадлежность к образовательному факультету или кафедре любого квебекского университета; получение финансирования (грант или иные варианты); наличие публикаций за определенный период работы, включенных в базы индексирования авторитетных журналов. Говоря более конкретно, учитывались специалисты, получившие поддержку из одного или более источников, входящих в перечень SIRU (грант, корпорация, государственное ведомство, общественная организация, фонд и др.) в период между 2001 и 2007 гг., и издавшие (самостоятельно или в соавторстве) хотя бы одну работу, проиндексированную в Web of Science в 20022008 гг. Ученые, отвечавшие лишь одному из двух упомянутых условий, в выборку не включались. В целях повышения качества анализа мы добавили годичный интервал, учитывающий временной лаг на подготовку статей между моментом получения финансовой поддержки и датой их выхода в свет [Adams, Griliches, 1998]. Всего были отобраны 194 преподавателя, ведущие научную деятельность в 16 квебекских вузах, причем все они имели ученую степень (PhD или ее эквивалент). Средний возраст представителей изучаемой когорты составил 53 года, а соотношение женщин и мужчин - 54\% на 46\%. Почти четверть исследователей (26\%) работают в англоязычных университетах, две трети $(66 \%)$ - сосредоточены в крупных вузах (критерием выделения последних служило наличие медицинского факультета). Приведенные параметры выборки отвечают критериям репрезентативности в терминах возраста, пола и работы в учебных заведениях, определенным ранее в ходе обследования научного персонала вузов и колледжей (University and College Academic Staff Survey, UCASS), выполненного по заказу Конференции ректоров и руководителей университетов Квебека (Conference of Rectors and Principals of Quebec Universities, CRÉPUQ).

Библиометрические индикаторы включают количество публикаций (индивидуальных и совместных), число цитирований, импакт-фактор, Н-индекс. При их расчете учитывались следующие категории работ: научные статьи, заметки и обзоры [Moed, 1996]. Структура объяснительных переменных, задействованных в анализе, представлена в табл. 1, а показатели объемов финансирования — в табл. 2 .

\section{Модель}

Объяснительная модель представляет собой линейное уравнение, позволяющее проанализировать характеристики продуктивности с помощью переменных, измеряющих привлеченные для производства знаний затраты. Такая модель неоднократно использовалась при оценке влияния объемов инвестиций на производительность исследований [Adams, Griliches, 1998; Bozeman, Gaughan, 2007; Carayol, Matt; 2006; Feldman, Lichtenberg, 1998]. В указанных работах применены логарифмические преобразования ключевых переменных, обеспечивающие интерпретацию коэффициентов регрессии, таких как индикаторы «нормы отдачи с изменением масштаба производства» или коэффициенты эластичности, устанавливающие связь между затратами и выходными показателями. Таким образом, расчеты поддаются трактовке во всех случаях, когда зависимые и независимые переменные преобразовываются в логарифм. Модель выражается формулой:

$$
Q=F(K, L, C),
$$

где $Q$ - значение измеренных результатов (число статей, эффект и т. д.), $K$ - вектор финансовых затрат, $L$ - вектор затрат в терминах характеристик человеческого капитала, а $C$ - вектор контекстуальных организационных характеристик (в том числе, размер университета, язык преподавания, экстерналии).

После логарифмической трансформации уравнение (1) принимает вид:

$$
\ln F(K, L, C)=\beta \ln K+\alpha \ln L+\omega \ln C+\varepsilon,
$$

где параметры $\beta, \alpha$ и $\omega-$ подлежащие оценке коэффициенты регрессии, а $\mathcal{\varepsilon}$ - остаточный член. Параметры $\beta, \alpha$ и $\omega$ можно интерпретировать в терминах эластичности - относительной дисперсии результатов (в процентах), вытекающей из аналогичного показателя затрат. Приведенные коэффициенты оце- 
Табл. 1. Описание переменных, использованных в данном исследовании

\begin{tabular}{|c|c|c|c|c|c|}
\hline Переменная & Описание & $\begin{array}{l}\text { Мин. } \\
\text { значение }\end{array}$ & $\begin{array}{l}\text { Макс. } \\
\text { значение }\end{array}$ & Медиана & $\begin{array}{l}\text { Стандартное } \\
\text { отклонение }\end{array}$ \\
\hline \multicolumn{6}{|c|}{ Зависимые переменные } \\
\hline $\begin{array}{l}\text { Общее число } \\
\text { публикаций (2002- } \\
2008)^{*}\end{array}$ & $\begin{array}{l}\text { Количество научных публикаций, } \\
\text { написанных каждым ученым. }\end{array}$ & 1 & 94 & 4.5 & 7.864 \\
\hline $\begin{array}{l}\text { Число совместных } \\
\text { публикациии (2002- } \\
2008)^{*}\end{array}$ & $\begin{array}{l}\text { При расчете данного показателя } \\
\text { учитывается доля публикации, написанная } \\
\text { соответствующим автором: если статья } \\
\text { имеет нескольких соавторов, вклад делится } \\
\text { между ними поровну. }\end{array}$ & 0.147 & 25 & 1.7 & 2.319 \\
\hline Число изитирований & $\begin{array}{l}\text { Число цитирований, полученных статьей в } \\
\text { течение пяти лет после ее публикации, для } \\
\text { всех соавторов. }\end{array}$ & 0 & 18.3 & 0.7 & 1.99 \\
\hline Импакт-фактор & $\begin{array}{l}\text { Показатель авторитетности научных } \\
\text { журналов, в которых были опубликованы } \\
\text { статьи вошедших в выборку ученых. } \\
\text { Импакт-фактор ежегодно рассчитывается } \\
\text { Институтом научной информации } \\
\text { (Institute for Scientific Information, ISI). }\end{array}$ & 0 & 3.6 & 0.6 & 0.673 \\
\hline Н-индекс & $\begin{array}{l}\text { Данный индекс отражает как количество } \\
\text { публикаций, так и число цитирований } \\
\text { в расчете на одну публикацию. } \\
\text { Рассчитывается с учетом максимального } \\
\text { количества статей, опубликованных } \\
\text { ученым, и числа цитирований каждой } \\
\text { статьи. }\end{array}$ & 0 & 11 & 1.56 & 1.672 \\
\hline \multicolumn{6}{|c|}{ Независимые переменные } \\
\hline $\begin{array}{l}\text { Совокупный объем } \\
\text { финансирования } \\
(2001-2007)^{\star}\end{array}$ & $\begin{array}{l}\text { Общий объем грантов на выполнение } \\
\text { научных исследований, полученных } \\
\text { каждым ученым (канадских долл.) }\end{array}$ & 50449 & 7796584 & 465151 & 801139.48 \\
\hline $\begin{array}{l}\text { Ассигнования } \\
\text { правительства } \\
\text { провиничии (2001- } \\
\text { 2007) }\end{array}$ & $\begin{array}{l}\text { Общий объем грантов на выполнение } \\
\text { научных исследований, полученных } \\
\text { каждым ученым от правительства } \\
\text { провинции (канадских долл.) }\end{array}$ & 0 & 7241456 & 186001 & 598021 \\
\hline $\begin{array}{l}\text { Ассигнования } \\
\text { федерального } \\
\text { правительства } \\
(2001-2007)^{*}\end{array}$ & $\begin{array}{l}\text { Общий объем грантов на выполнение } \\
\text { научных исследований, полученных } \\
\text { каждым ученым от федерального } \\
\text { правительства (канадских долл.) }\end{array}$ & 0 & 1909208 & 181371 & 263702 \\
\hline $\begin{array}{l}\text { Средства, } \\
\text { полученные от } \\
\text { корпораичй (2001- } \\
\text { 2007) }\end{array}$ & $\begin{array}{l}\text { Общий объем грантов на выполнение } \\
\text { научных исследований, полученных } \\
\text { каждым ученым от частных компаний } \\
\text { (канадских долл.) }\end{array}$ & 0 & 263767 & 8686 & 32992 \\
\hline $\begin{array}{l}\text { Средства, } \\
\text { полученные от } \\
\text { финансируюших } \\
\text { советов, и гранты на } \\
\text { научные исследования } \\
(2001-2007)^{*}\end{array}$ & $\begin{array}{l}\text { Общий объем средств, полученный } \\
\text { от финансирующих советов, или в } \\
\text { виде грантов на выполнение научных } \\
\text { исследований (2001-2008, канадских долл.) }\end{array}$ & 0 & 1513752 & 219387 & 224937 \\
\hline Возраст & $\begin{array}{l}\text { Возраст исследователя (количество полных } \\
\text { лет) в } 2008 \text { г. }\end{array}$ & 43 & 72 & 53.24 & 9.82 \\
\hline Пол & $\begin{array}{l}\text { Пол исследователя. Дихотомическая } \\
\text { переменная: мужской=0, женский=1. }\end{array}$ & 0 & 1 & 0.54 & 0.5 \\
\hline $\begin{array}{l}\text { Язык преподавания } \\
\text { в университете }\end{array}$ & $\begin{array}{l}\text { Дихотомическая переменная: } \\
\text { французский=0, английский=1 }\end{array}$ & 0 & 1 & 0.26 & 0.439 \\
\hline $\begin{array}{l}\text { Принадлежность } \\
\text { к круному } \\
\text { университету } \\
\text { (имеюшему } \\
\text { медииинский } \\
\text { факультет) }\end{array}$ & Дихотомическая переменная: нет=0, да=1 & 0 & 1 & 0.66 & 0.474 \\
\hline
\end{tabular}

* Перед использованием в регрессионной модели переменные с данной показательной функцией были преобразованы в натуральный логарифм.

Табл. 2. Показатели финансовой поддержки исследователей, вошедших в выборку: 2001-2007

\begin{tabular}{|l|c|c|c|}
\hline \multicolumn{1}{|c|}{ Наименование показателя } & \multicolumn{2}{|c|}{$\begin{array}{c}\text { В расчете на одного исследователя } \\
\text { (канадских долл.) }\end{array}$} & $\begin{array}{c}\text { Стандартное } \\
\text { отклонение } \\
\text { (канадских долл.) }\end{array}$ \\
\cline { 1 - 4 } & средний & $7.8 \mathrm{mлн}$ & 801139 \\
\hline Совокупный объем финансирования & 465151 & $7.2 \mathrm{mлн}$ & 598021 \\
\hline Ассигнования правительства провинции Квебека & 186001 & 263767 & 263702 \\
\hline Ассигнования федерального правительства & 181371 & 1.9 млн & 32992 \\
\hline Средства корпораций & 8686 & & \\
\hline
\end{tabular}


ниваются посредством эмпирических данных. Оценка коэффициентов регрессии проведена с использованием метода обычных наименьших квадратов, который также применялся для объяснения продуктивности по пяти индикаторам:

- фактическое количество публикаций;

- Н-индекс;

- доля совместных работ (относительный вес статей, написанных в соавторстве);

- число цитирований на одного ученого;

- импакт-фактор.

Каждая из упомянутых характеристик, служащих зависимыми переменными, обладает преимуществами и недостатками. Они не измеряют в точности одни и те же факторы, но тем не менее поддаются корреляции, что не влияет на валидность результатов нашего анализа.

\section{Результаты и их интерпретация}

Ниже изложены результаты статистических измерений, которые предполагали оценку выделяемых средств, как по совокупному объему, так и с распределением по источникам (исследовательские советы, федеральные и региональные органы власти, частный сектор). Мы провели факторный анализ зависимых переменных с целью структурирования объясняющих их индикаторов в подмножества коррелятов для измерения производительности (табл. 3). Выявлены два фактора, объясняющих 85\% дисперсии значений переменных. Первый охватывает общее число статей, долю совместных работ и Н-индекс; он позволяет предположить, что публикационная активность ученых более чем на 50\% определяется количественными характеристиками. Второй фактор связан с качеством работ, измеряемым через цитирование и влиятельность издавших их журналов, объясняя треть дисперсии показателей продуктивности ученых. Полученные выводы свидетельствуют, что количество статей не гарантирует успех в терминах цитирования и научного влияния. Отметим, что они согласуются с выводами, описанными в работе [Costas et al., 2010], где аналогичный факторный анализ проводился отдельно по качественным и количественным параметрам, несмотря на то что Н-индекс объединяет обе категории.

В табл. 4 и 5 приведены результаты оценки финансирования по двум версиям объяснительной модели - упрощенной (агрегирующей показатели валовых инвестиций в единую переменную) и детализирующей (с распределением полученных средств по источникам и объемам). Этим расчетам предшествовала специальная обработка данных в целях минимизации влияния факторов, снижающих статистическую валидность анализа и регрессий, которые описывают детерминантную связь между объясняемыми и объяснительными переменными. Прежде всего, обрабатывались резкие отклонения. По каждой переменной выявлены и верифицированы случаи выхода за рамки стандартного отклонения \pm 3.3 , часть которых были скорректированы, а остальные исключены. Особое внимание уделялось оценке соответствия распределения изучаемых переменных нормальному характеру. Тесты на асимметричность и эксцессы продемонстрировали весьма приемлемые характеристики по всем переменным. Повышению качества распределения изучаемых переменных способствовали и логарифмические преобразования, предназначенные для интерпретации коэффициентов эластичности и регрессии, а также корректировки искажения данных. Значения индикатора $F$ в различных регрессионных таблицах свидетельствуют об адекватности выбранных объяснительных показателей для изучения зависимых переменных. Для выявления возможной мультиколлинеарности были проанализированы коэффициенты корреляции между различными объяснительными переменными. Результаты оказались однозначными: ни один коэффициент не превышает 0.7. Наконец, для различных регрессий тестировался фактор роста дисперсии (variance inflation factor, VIF); ни по одной из объяснительных переменных его значение не превысило 3, что свидетельствует об отсутствии риска мультиколлинеарности.

\section{Эффект агрегированного финансирования}

Табл. 4 содержит результаты регрессионного анализа совокупных вложений. Общие показатели отдачи, оцененные в диапазоне от «высокой» до «средней» (значение параметра $R^{2}-23-29 \%$ ) при статистически значимом параметре Fs подтверждают адекватность используемой эмпирической модели. Коэффициенты регрессии, приведенные в таблицах, не стандартизованы.

Коэффициент регрессии отражает эластичность (связь относительных дисперсий результатов и затрат). Все значения этого показателя для переменной, характеризующей совокупный объем инвестиций в расчете на одного ученого, являются положительными (варьируются от 0.17 до 0.32) и статистически значимыми, что доказывает значимость влияния финансирования на продуктивность исследований. Так, становится очевидным, что 10\%-е увеличение финансирования обусловливает прирост числа публикаций на 3\%, медианного Н-индекса, числа совместных ра-

Табл. 3. Факторный анализ зависимых переменных (с использованием варимакс-вращения и нормализации Кайзера)

Показатели за 2002-2008 гг.

Число публикаций

Число совместных публикаций

Н-индекс

Число цитирований

Импакт-фактор
Факторы (объясняющие 85\% дисперсии)

Число публикаций (53\% дисперсии) (32\% дисперсии)

0.973

0.963

0.885 
Табл. 4. Детерминанты продуктивности: упрощенная модель (регрессия наименьших квадратов)

\begin{tabular}{|c|c|c|c|c|c|c|c|c|c|c|}
\hline \multirow{3}{*}{\begin{tabular}{|l} 
\\
Независимые переменные \\
Константа \\
\end{tabular}} & \multicolumn{2}{|c|}{$\begin{array}{c}\text { Общее число } \\
\text { публикаций (ln) }\end{array}$} & \multicolumn{2}{|c|}{ Н-индекс(ln) } & \multicolumn{2}{|c|}{$\begin{array}{c}\text { Совместные } \\
\text { публикации (ln) }\end{array}$} & \multicolumn{2}{|c|}{$\begin{array}{c}\text { Цитирование } \\
\text { (ln) }\end{array}$} & \multicolumn{2}{|c|}{$\begin{array}{c}\text { Импакт-фактор } \\
(\ln )\end{array}$} \\
\hline & \multicolumn{2}{|c|}{$\mathrm{B}(\mathrm{CO})$} & \multicolumn{2}{|c|}{$\mathrm{B}(\mathrm{CO})$} & \multicolumn{2}{|c|}{$\mathrm{B}(\mathrm{CO})$} & \multicolumn{2}{|c|}{$\mathrm{B}(\mathrm{CO})$} & $\mathrm{B}(\mathrm{C}$ & \\
\hline & $-1.98^{\star \star *}$ & $(0.744)$ & -0.411 & $(0.76)$ & $-1.6^{\star * *}$ & $(0.51)$ & -0.83 & $(0.648)$ & 0.40 & $(0.38)$ \\
\hline \multicolumn{11}{|l|}{ Индивидуальные факторы } \\
\hline Возраст & $-0.015^{\star * *}$ & $(0.005)$ & $-0.019^{\star}$ & $(0.05)$ & $-0.11^{\star * *}$ & $(0.04)$ & $-0.15^{\star * *}$ & $(0.005)$ & $-0.006^{*}$ & $(0.003)$ \\
\hline Пол (женский=1; мужской=0) & $-0,15$ & $(0,106)$ & $-0,17$ & $(0,09)$ & $-0,06$ & $(0,74)$ & $-0,26$ & $(0,09)$ & $-0,07$ & $(0,054)$ \\
\hline
\end{tabular}

Организационные факторы (характеристика университета)

\begin{tabular}{|c|c|c|c|c|c|c|c|c|c|c|}
\hline $\begin{array}{l}\text { Язык преподавания } \\
\text { (английский=1, французский=0) }\end{array}$ & $0.492^{* * *}$ & $(0.126)$ & $0.395^{\star * *}$ & $(0.102)$ & $0.343^{\star * *}$ & $(0.088)$ & $0.61^{* * *}$ & $(0.11)$ & $0.153^{\star * *}$ & $(0.05)$ \\
\hline $\begin{array}{l}\text { Размер университета (крупный=1, } \\
\text { малый=0) }\end{array}$ & $0.202^{*}$ & $(0.107)$ & 0.096 & $(0.10)$ & $0.157^{\star *}$ & $(0.074)$ & 0.02 & $(0.09)$ & 0.045 & $(0.55)$ \\
\hline \multicolumn{11}{|c|}{ Финансовые факторы (гранты, канадских долл.) } \\
\hline Общий объем в 2001-2007 гг. $(\ln )$ & $0.315^{\star * *}$ & $(0.52)$ & $0.169^{* * *}$ & $(0.051)$ & $0.21^{* * *}$ & $(0.03)$ & $0.15^{\star * *}$ & $(0.04)$ & $0.11^{* * *}$ & $(0.027)$ \\
\hline$R^{2}$ & & 0.29 & & 0.28 & & 0.26 & & 0.23 & & 0.27 \\
\hline Статистическая значимость & & $0.000^{* * *}$ & & $0.000^{\star * *}$ & & $0.000^{* * *}$ & & $.000^{* * *}$ & & $0.000^{* * *}$ \\
\hline$F$ & & 13.5 & & 8.62 & & 12.16 & & 9.8 & & 3.22 \\
\hline$N$ & & 187 & & 167 & & 185 & & 174 & & 112 \\
\hline
\end{tabular}

${ }^{* * *} \mathrm{p}<0,01 ;{ }^{* *} \mathrm{p}<0,05,{ }^{*} \mathrm{p}<0,1 \quad \mathrm{CO}=$ стандартная ошибка $\quad \ln =$ натуральный логарифм

бот и цитирований - на 2 и, наконец, медианного импакт-фактора - на 1\%. Приведенные величины характеристик эластичности в целом соответствуют оценкам, выполненным с использованием сходных данных в США [Adams, Griliches, 1998]. Данный факт говорит о том, что с ростом «масштабов производства» и, следовательно, увеличением финансового обеспечения науки «норма отдачи» падает.

В отношении влияния индивидуальных характеристик на продуктивность научных кадров анализ показал, что с увеличением возраста она снижается. Иными словами, чем моложе ученый, тем больше он производит. Вместе с тем существенного влияния пола на переменные продуктивности не выявлено.
Следующий влиятельный фактор - институциональные характеристики учебных заведений. Как правило, исследователи из англоязычных университетов (McGill, Concordia, Bishop's) публикуются и цитируются чаще, а их статьи имеют более высокий импактфактор. Данный факт не вызывает удивления, так как журналы, индексируемые в использованной нами базе данных Web of Science, являются преимущественно англоязычными. Аналогично, сотрудники крупных вузов, в структуре которых присутствует факультет медицины, издают больше работ по сравнению с коллегами из вузов меньшего размера. Одно из возможных объяснений - учебные заведения первой из упомянутых категорий отличаются повышенной

Табл. 5. Детерминанты продуктивности: расширенная модель (регрессия наименьших квадратов)

\begin{tabular}{|c|c|c|c|c|c|c|c|c|c|c|}
\hline \multirow{3}{*}{\begin{tabular}{|l} 
Независимые переменные \\
Константа \\
\end{tabular}} & \multirow{2}{*}{\multicolumn{2}{|c|}{$\begin{array}{c}\begin{array}{c}\text { Общее число } \\
\text { публикаций } \\
(\ln )\end{array} \\
\text { B(CO) }\end{array}$}} & \multirow{2}{*}{\multicolumn{2}{|c|}{ Н-индекс(ln) }} & \multirow{2}{*}{\multicolumn{2}{|c|}{$\begin{array}{c}\text { Совместные } \\
\text { публикации } \\
(\ln )\end{array}$}} & \multicolumn{2}{|c|}{$\begin{array}{l}\text { Цитирование } \\
\text { (ln) }\end{array}$} & \multicolumn{2}{|c|}{$\begin{array}{l}\text { Фактор } \\
\text { эффекта }(\ln )\end{array}$} \\
\hline & & & & & & & $B(C$ & (O) & $B(C$ & (O) \\
\hline & -0.48 & $(0.58)$ & -0.53 & $(0.54)$ & -0.55 & $(0.4)$ & -0.29 & $(0.49)$ & $0.78^{\star *}$ & $(0.3)$ \\
\hline \multicolumn{11}{|l|}{ Индивидуальнье факторь } \\
\hline Возраст & $-0.01^{\star * *}$ & $(0.006)$ & $-0.017^{\star * *}$ & $(0.006)$ & -0.003 & $(0.004)$ & -0.011 & $(0.005)$ & $-0.07^{\star}$ & $(0.03)$ \\
\hline Пол (женский=1; мужской=0) & $-0.18^{\star}$ & $(0.1)$ & $-0.19^{\star *}$ & $(0.09)$ & -0.07 & $(0.07)$ & -0.044 & $(0.092)$ & -0.08 & $(0.053)$ \\
\hline \multicolumn{11}{|c|}{ Организационнье факторы (характеристика университета) } \\
\hline $\begin{array}{l}\text { Язык преподавания } \\
\text { (английский=1, французский=0) }\end{array}$ & $0.49^{\star * *}$ & $(0.132)$ & $0.369^{* * *}$ & $(0.104)$ & $0.351^{\star * *}$ & $(0.091)$ & $0.59^{* * *}$ & $(0.11)$ & $0.159^{* * *}$ & $(0.057)$ \\
\hline $\begin{array}{l}\text { Размер университета (крупный=1, } \\
\text { малый=0) }\end{array}$ & $0.24^{\star *}$ & $(0.1)$ & 0.13 & $(0.097)$ & $0.18^{\star *}$ & $(0.076)$ & 0.043 & $(0.094)$ & 0.078 & $(0.054)$ \\
\hline \multicolumn{11}{|c|}{ Финансовье факторы (объем грантов) } \\
\hline $\begin{array}{l}\text { Академические фонды и советы } \\
(\ln )\end{array}$ & $0.132^{* * *}$ & $(0.037)$ & $0.08^{\star * *}$ & $(0.03)$ & $0.088^{* * *}$ & $(0.026)$ & $0.072^{\star *}$ & $(0.032)$ & -0.003 & $(0.016)$ \\
\hline Федеральное правительство (ln) & 0.03 & $(0.02)$ & 0.03 & $(0.02)$ & 0.01 & $(0.01)$ & 0.023 & $(0.017)$ & 0.011 & $(0.013)$ \\
\hline Правительство провинции (ln) & $0.028^{\star *}$ & $(0.015)$ & 0.03 & $(0.023)$ & $0.024^{\star *}$ & $(0.01)$ & 0.003 & $(0.012)$ & 0.007 & $(0.007)$ \\
\hline Частный сектор (ln) & 0.008 & $(0,016)$ & 0.008 & $(0.015)$ & -0.002 & $(0.11)$ & -0.015 & $(0.014)$ & 0.008 & $(0.008)$ \\
\hline$R^{2}$ & & 0.26 & & 0.29 & & 0.24 & & 0.23 & & 0.14 \\
\hline Статистическая значимость & & $.000^{\star * *}$ & & $0.000^{* * *}$ & & $0.00^{\star *}$ & & $0.000^{\star * *}$ & & $0.03^{\star *}$ \\
\hline$F$ & & 7.35 & & 5.54 & & 6.55 & & 6.213 & & 2.28 \\
\hline$N$ & & 174 & & 145 & & 165 & & 174 & & 112 \\
\hline
\end{tabular}

${ }^{* * *} \mathrm{p}<0,01 ;{ }^{* *} \mathrm{p}<0,05,{ }^{*} \mathrm{p}<0,1$

$\mathrm{CO}=$ стандартная ошибка

$\ln =$ натуральный логарифм 
престижностью и способны привлекать наиболее талантливых молодых ученых. Однако переменная размера не дает статистически значимых коэффициентов регрессии для Н-индекса, количества цитирований и импакт-фактора. Это говорит о том, что качество публикаций не всегда зависит от размера заведения, в котором работает ученый.

\section{Эффект источника финансирования}

В целях более углубленной оценки вклада финансирования в продуктивность научной деятельности мы проанализировали его по четырем категориям источников:

- академическое, выделяемое финансовыми советами;

- ассигнования со стороны федерального правительства;

- выделение средств из регионального бюджета;

- поддержка со стороны корпораций и некоммерческих организаций.

Итоги соответствующих расчетов отражены в табл. 5. Из нее видно, что положительные статистические значимые коэффициенты регрессии имеются лишь для некоторых вышеназванных источников. Полученные данные свидетельствуют, что лишь академическая поддержка и гранты оказывают позитивный и статистически значимый эффект в отношении почти всех индикаторов продуктивности. Соответственно, ученые, получающие средства из этих источников, демонстрируют более высокую производительность; 10\%-ное увеличение такой поддержки обеспечивает аналогичный рост числа статей. Что закономерно: публикация достигнутых результатов в научных изданиях - обязательное условие получения средства от этих субъектов. Поступления из этого источника также имеют значительное влияние в отношении Н-индекса, количества совместных работ и цитирований.

Далее, выявлена положительная и статистически значимая связь числа статей (как индивидуальных, так и совместных) с объемом средств, выделяемых правительством Квебека. Другими словами, вклад со стороны федерального правительства и частного сектора не является вектором продуктивности. Возможно, причина в том, что в Квебеке принципиальные решения об адресатах поддержки и направлениях исследований принимаются на уровне провинции, однако это предположение требует уточнения.

\section{Заключение}

В данной работе проанализированы факторы, определяющие продуктивность исследований, выполняемых сотрудниками университетов. Как основной рассматривалась финансовая поддержка, которая оценивалась как в абсолютном отношении, так и с распределением по источникам. Кроме того, изучалось влияние и дру- гих показателей, таких как возраст и пол ученых, язык преподавания и размер учебного заведения.

Результаты анализа подтвердили нашу гипотезу о том, что финансирование - ключевая составляющая вклада в продуктивность науки в целом и вузовской в частности. Наблюдается положительная связь между интенсивностью затрат и количеством изданных работ. Она подтверждается коэффициентами регрессии со значением менее 1 , что означает снижение «нормы отдачи» при росте «масштабов производства». Установлено, что эластичность научной продукции по отношению к расходам на ее производство составляет примерно 0.32 в терминах числа публикаций. Иными словами, при прочих равных условиях 10\%-й прирост выделяемых средств в среднем обеспечивает 3\%-е увеличение объема исследовательских работ.

Для других детерминант наблюдаемая эластичность оказалась слабее - в диапазоне от 0.11 до 0.21 . Таким образом, в соответствии с использованными индикаторами, влияние затрат на качество результатов может быть более или менее значительным. Можно утверждать, что расходы на эту деятельность стимулируют повышение числа статей (как индивидуальных, так и совместных). Однако с учетом индикаторов, отражающих научную ценность публикаций (Н-индекс, цитирование, импакт-фактор), действенность данного «рычага» резко снижается.

В отношении источников финансирования, наиболее положительное влияние на продуктивность ученых продемонстрировала поддержка из регионального бюджета. Опять-таки, эта эффективность снижается (менее 1\% прироста на 10\%-е увеличение инвестиций), если принимать в расчет иные индикаторы, помимо общего числа публикаций.

Кроме того, подтверждена роль других детерминантов продуктивности ученых, таких как: возраст ученых, язык преподавания и размер учреждений, в которых они работают. В целом, более высокую производительность демонстрируют молодые кадры, а также исследователи из крупных университетов (имеющих подразделение по подготовке медиков) и/или преподающих на английском языке.

Выявленные в ходе нашего анализа закономерности целесообразно учитывать при экспертизе итогов реализации программ. Важно, чтобы принимались во внимание не только валовые показатели (количество подготовленных статей), но и качество этих публикаций (цитирование и реальные результаты, полученные на основе изданных работ), а также персональные характеристики авторов и организационный контекст. Тем самым разработчики инициатив по поддержке научных исследований получат максимально полную информацию, необходимую для повышения эффективности соответствующих программ.

Abramo G., D’Angelo C.A., Caprasecca A. (2009) Allocative Efficiency in Public Research Funding: Can Bibliometrics Help? // Research Policy. Vol. 38. № 1. P. 206-215.

Adams J.D., Griliches Z. (1996) Research Productivity in a System of Universities // National Bureau of Economic Research Working Papers series. Vol. 5833. P. 1-28.

Adams J.D., Griliches Z. (1998) Research Productivity in a System of Universities // Annales déconomie et de statistique. Vol. 49/50. P. 127-164. Auranen O., Nieminen M. (2010) University Research Funding and Publication Performance - An International Comparison // Research Policy. Vol. 39. № 6. P. 822-834.

Blau P.M., Margulies R.Z. (1975) The Reputations of American Professional Schools // Change. Vol. 6. № 10. P. $42-47$. 
Bozeman B., Gaughan M. (2007) Impacts of Grants and Contracts on Academic Researchers' Interactions with Industry // Research Policy. Vol. 36. № 5. P. 694-670.

Brainerd C.J. (2006) Developmental Review’s Most Influential Articles // Developmental Review. Vol. 26. № 1. P. 1-14.

Campanario J.M., González L., Rodriguez C. (2006) Structure of the Impact Factor of Academic Journals in the Feld of Education and Educational Psychology: Citations from Editorial Board Members // Scientometrics. Vol. 69. № 1. P. 37-56.

Campbell R. (1979) Fifteenth Anniversary Perspective: A Critique of the Educational Administration Quaterly // Library Review. Vol. 15. № 3. P. $1-19$.

Carayol N., Matt M. (2006) Individual and Collective Determinants of Academic Scientists' Productivity // Information Economics and Policy.

Vol. 18. № 1. P. 55-72.

Cartter A. (1977) The Cartter Report on the Leading Schools of Education, Law and Business // Change. Vol. 9. № 2. P. 44-48.

Clark D.L., Guba E.G. (1976) Studies of Productivity in Knowledge Production and Utilization by Schools, Colleges and Departments of Education // Research on Institutions of Teacher Education. Bloomington, IN: Indiana University.

Costas R., van Leeuwen T.N., Bordons M. (2010) A Bibliometric Classificatory Approach for the Study and Assessment of Research Performance at the Individual Level: The Effects of Age on Productivity and Impact // Journal of the American Society for Information Science and Technology. Vol. 61. № 8. P. 1564-1581.

Defazio D.A., Lockett A., Wright M. (2009) Funding Incentives, Collaborative Dynamics and Scientific Productivity: Evidence from the EU Framework Program // Research Policy. Vol. 38. № 2. P. 293-305.

Denton J.J., Tsai C.-Y., Cloud C. (1986) Productivity of Faculty in Higher Education Institutions // Journal of Teacher Education. Vol. 37. № 5. P. $12-16$.

Eash J. (1983) Educational Research Productivity of Institutions of Higher Education // American Educational Research Journal. Vol. 20. № 1. P. 5-12.

Edwards T. (2000) All the Evidence Shows...: Reasonable Expectations of Educational Research // Oxford Review of Education. Vol. 26. № 3-4. P. 299-311.

Elton L. (2000) The UK Research Assessment Exercice: Unintended Consequences // Higher Education Quartely. Vol. 54. № 3. P. $274-283$.

Feldman M.P., Lichtenberg F.R. (1998) The Impact and Organization of Publicly-Funded Research and Development in the European Community // Annals of Economics and Statistics. Vol. 49/50. P. 199-222.

Garfield E. (1979) Citation Indexing - Its Theory and Application in Science, Technology and Humanities. New York, NY: John Wiley \& Sons. Garfield E. (1990) How ISI Selects Journals for Coverage: Quantitative and Qualitative Considerations // Current Contents. Vol. 13. № 22. P. 185. Geuna A., Martin B.R. (2003) University Research Evaluation and Funding: An International Comparison // Minerva. Vol. 41. № 4. P. $277-304$. Gingras Y., Larivière V., Macaluso B., Robitaille J.-P. (2008) The Effect of Aging on Researchers' Publication and Citation Pattern // PLoS ONE.

Vol. 3. № 12. P. 40-48.

Glanzel W., Moed H.F. (2002) Journal Impact Measures in Bibliometric Research // Scientometrics. Vol. 53. № 2. P. $171-193$.

Goldfinch S. (2003) Investing in Excellence? The Performance-based Research Fund and its Implications for Political Science Departments in New Zealand // Political Science. Vol. 55. № 1. P. 39-55.

Gordon N.J., Nucci L.P., West C.K., Hoerr W.A., Uguroglu M.E., Vukosavich P., Tsai S.-L. (1984) Productivity and Citations of Educational Research: Using Educational Psychology as the Data Base // Educational Researcher. Vol. 13. № 7. P. 14-20.

Haas E., Wilson G.Y., Cobb C.D., Hyle A.E., Jordan K., Kearney K.S. (2007) Assessing Influence on the Field: An Analysis of Citations to Educational Administration Quarterly, 1979-2003 // Educational Administration Quarterly. Vol. 43. № 4. P. 494-512.

Heckman J.J., Cameron S. (2001) The Dynamics of Educational Attainment for Blacks, Whites and Hispanics // Journal of Political Economy. Vol. 109. № 3. P. 455-499.

Hesli V.L., Lee J.M. (2011) Faculty Research Productivity: Why Do Some of our Colleagues Publish More than Others? // Political Science \& Politics. Vol. 44. № 2. P. 393-408.

Hicks D., Tomizawa H., Saitoh Y., Kobayashi S. (2004) Evolving Indicators, Bibliometric Techniques in the Evaluation of Federally Funded Research in the United States // Research Evaluation. Vol. 13. № 2. P. 78-86.

Hesli V.L., Lee J.M. (2011) Faculty Research Productivity: Why Do Some of Our Colleagues Publish More than Others? // Political Science \& Politics. Vol. 44. № 2. P. 393-408.

Kroc R.J. (1984) Using Citation Analysis to Assess Scholarly Productivity // Educational Researcher. Vol. 13. № 6. P. 17-22.

Ladd E.C., Lipset S.M. (1979) The 1977 Survey of the American Professoriate // Chronicle of Higher Education. Vol. 17. № 18. P. 7-8.

Larivière V., Macaluso B., Archambault É., Gingras Y. (2010) Which Scientific Elites? On the Concentration of Research Funds, Publications and Citations // Research Evaluation. Vol. 19. № 1. P. 45-53.

Lehman H.C. (1953) Age and Achievement. Princeton, NJ: Princeton University Press.

Levin S.G., Stephan P. (1998) Gender Differences in the Rewards to Publishing in Academe: Science in the 1970’s // Sex Roles. Vol. 38. № 11/12. P. 1049-1064.

Lindsey D. (1978) The Scientific Publication in Social Science. San Francisco, CA: Jossey-Bass.

Luce T., Johnson D. (1978) Rating of Educational and Psychological Journals // Educational Researcher. Vol. 7. № 10. P. 8-10.

Marinova D., Newman P. (2008) The Changing Research Funding Regime in Australia and Academic Productivity // Mathematics and Computers in Simulation. Vol. 78. № 2-3. P. 283-291.

Mayo C.R., Zirkel P.A., Finger B.A. (2006) Which Journals are Educational Leadership Professors Choosing? // Educational Administration Quarterly. Vol. 42. № 5. P. 806-811.

Moed H.F. (1996) Differences in the Construction of SCI Based Bibliometric Indicators among Various Producers: A First Overview // Scientometrics. Vol. 35. № 2. P. 177-191.

Mortimore P. (1999) Does Educational Research Matter? // British Educational Research Journal. Vol. 26. № 1. P. 5-24.

Orr M. (2004) Political Science and Education Research: An Exploratory Look at two Political Science Journals // Educational Researcher. Vol. 33. № 5. P. 11-16.

Ouimet M., Bédard P.-O., Gélineau F. (2011) Are the H-Index and Some of Its Alternatives Discriminatory of Epistemological Beliefs and Methodological Preferences of Faculty Members? The Case of Social Scientists in Quebec // Scientometrics. Vol. 88. № 1. P. 91-106.

Piaget J. (1972) L’Épistémologie Génétique. Paris: Presses universitaires de France.

Sieber S.D. (1966) The Organization of Educational Research. New York, NY: Columbia University, Bureau of Applied Social Research

Smart J.C., Elton C.F. (1981) Structural Characteristics and Citation Rates of Education Journals // American Educational Research Journal. Vol. 18. № 4. P. 399-413.

Smith N.L., Caulley D.N. (1981) The Evaluation of Educational Journals Through the Study of Citations // Educational Researcher. Vol. 10 . № 5. P. 11-24.

Turner L., Mairesse J. (2003) Explaining Individual Productivity Differences in Scientific Research Productivity: How Important are Institutional and Individual Determinants? An Econometric Analysis of the Publications of French CNRS Physicists in Condensed Matter: 1980-1997 (Working Paper). University of Sorbonne, France.

Walberg H.J. (1972) University Distinction in Educational Research: An Exploratory Survey // Educational Researcher. Vol. 1. № 1. P. 15-16. Walberg H.J., Rasher S.P., Mantel H. (1977) Eminence and Citations in Educational Psychology // Educational Researcher. Vol. 6. № 3. P. 12-13.

Walberg H.J., Vukosavich P., Tsai S.L. (1981) Scope and Structure of the Journal Literature in Educational Research // Educational Researcher. Vol. 10. № 8. P. 11-13.

West C.K. (1978) Productivity Ratings of Institutions Based on Publications in Journals of the American Educational Research Association: 19701976 // Educational Researcher. Vol. 7. № 2. P. 13-14. 


\title{
Factors Influencing Research Productivity in Higher Education: An Empirical Investigation
}

\author{
Johann Jacob \\ Evaluation Project Manager. E-mail: johann.jacob@enap.ca
}

Moktar Lamari

Director. E-mail: moktar.lamari@enap.ca

Centre d'expertise et de recherche en évaluation de programmes (CREXE), École nationale d'administration publique, Université du Québec, Canada

Address: 555, boulevard Charest Est, Québec (Québec) G1K 9E5

\begin{abstract}
$\mathrm{U}$ niversities play an increasingly significant role in producing new knowledge. The relationship between research inputs (grants, infrastructure spending, training of researchers) and research outputs (number of publications, citation, impact) emerges, therefore, as a strategic issue for public decision-making on funding in support of innovation and the development of competencies. Despite the abundance of empirical works on the question of researcher productivity, there is a paucity of studies dealing with this issue in the context of higher eductaion.

This paper seeks to identify the factors that explain research productivity in higher education, using as a case study, the universities in Quebec-Canada. The main hypothesis is that productivity in scientific research is significantly influenced by the volume and origin of the funding sources mobilized to support scientific research performance. We analyzed data on 194 researchers for the period of 2001-2008. Individual publications in referred journals (number of publications, fractioned publications, citations, impacts) were used as indicators for research

productivity. Factor analysis and linear regression served as tools for evaluation.

Our findings imply that the volume of funding is not as influential as supposed. We revealed that age and language (Francophone versus Anglophone) of university instruction, and, in addition, the origin of funding do affect researcher productivity. Generally speaking, young researchers, as well as those affiliated with Anglophone or/and large universities tend to produce more publications. The gender of researcher does not seem to significantly influence the productivity variables.

The results of our analysis should motivate program evaluators who assess the benefits of public funding and intervention to support academic research. It is essential that evaluators do not only see these benefits in terms of number of publications produced, but also through the prism of publication quality (citations and outcomes generated) as well as individual and organizational attributes. In this way, those designing interventions to support research will benefit from the fully-fledged information necessary to improve program effectiveness.
\end{abstract}

\section{Keywords}

university research; bibliometric indicators; research funding; research productivity; impact evaluation; impact factor.

\section{References}

Abramo G., D’Angelo C.A., Caprasecca A. (2009) Allocative Efficiency in Public Research Funding: Can Bibliometrics Help? Research Policy, vol. 38, no 1, pp. 206-215.

Adams J.D., Griliches Z. (1996) Research Productivity in a System of Universities. National Bureau of Economic Research Working Papers series, vol. 5833, pp. 1-28.

Adams J.D., Griliches Z. (1998) Research Productivity in a System of Universities. Annales déconomie et de statistique, vol. 49/50, pp. 127-164.

Auranen O., Nieminen M. (2010) University Research Funding and Publication Performance - An International Comparison. Research Policy, vol. 39, no 6, pp. 822-834.

Blau P.M., Margulies R.Z. (1975) The Reputations of American Professional Schools. Change, vol. 6, no 10, pp. 42-47.

Bozeman B., Gaughan M. (2007) Impacts of Grants and Contracts on Academic Researchers' Interactions with Industry. Research Policy, vol. 36, no 5, pp. 694-670.

Brainerd C.J. (2006) Developmental Review's Most Influential Articles. Developmental Review, vol. 26, no 1. p. 1-14.

Campanario J.M., González L., Rodriguez C. (2006) Structure of the Impact Factor of Academic Journals in the Feld of Education and Educational Psychology: Citations from Editorial Board Members. Scientometrics, vol. 69, no 1, pp. 37-56.

Campbell R. (1979) Fifteenth Anniversary Perspective: A Critique of the Educational Administration Quaterly. Library Review, vol. 15, no 3, pp. $1-19$. 
Carayol N., Matt M. (2006) Individual and Collective Determinants of Academic Scientists' Productivity. Information Economics and Policy, vol. 18 , no 1 , pp. $55-72$.

Cartter A. (1977) The Cartter Report on the Leading Schools of Education, Law and Business. Change, vol. 9, no 2, pp. 44-48.

Clark D.L., Guba E.G. (1976) Studies of Productivity in Knowledge Production and Utilization by Schools, Colleges and Departments of Education. Research on Institutions of Teacher Education, Bloomington, IN: Indiana University.

Costas R., van Leeuwen T.N., Bordons M. (2010) A Bibliometric Classificatory Approach for the Study and Assessment of Research Performance at the Individual Level: The Effects of Age on Productivity and Impact. Journal of the American Society for Information Science and Technology, vol. 61, no 8, pp. 1564-1581.

Defazio D.A., Lockett A., Wright M. (2009) Funding Incentives, Collaborative Dynamics and Scientific Productivity: Evidence from the EU Framework Program. Research Policy, vol. 38, no 2, pp. 293-305.

Denton J.J., Tsai C.-Y., Cloud C. (1986) Productivity of Faculty in Higher Education Institutions. Journal of Teacher Education, vol. 37, no 5, pp. $12-16$.

Eash J. (1983) Educational Research Productivity of Institutions of Higher Education. American Educational Research Journal, vol. 20, no 1, pp. $5-12$.

Edwards T. (2000) All the Evidence Shows...: Reasonable Expectations of Educational Research. Oxford Review of Education, vol. 26, no 3-4, pp. 299-311.

Elton L. (2000) The UK Research Assessment Exercice: Unintended Consequences. Higher Education Quartely, vol. 54, no 3, pp. $274-283$.

Feldman M.P., Lichtenberg F.R. (1998) The Impact and Organization of Publicly-Funded Research and Development in the European Community. Annals of Economics and Statistics, vol. 49/50, pp. 199-222.

Garfield E. (1979) Citation Indexing - Its Theory and Application in Science, Technology and Humanities. New York, NY: John Wiley \& Sons.

Garfield E. (1990) How ISI Selects Journals for Coverage: Quantitative and Qualitative Considerations. Current Contents, vol. 13 , no 22 , p. 185.

Geuna A., Martin B.R. (2003) University Research Evaluation and Funding: An International Comparison. Minerva, vol. 41, no 4, pp. $277-304$.

Gingras Y., Larivière V., Macaluso B., Robitaille J.-P. (2008) The Effect of Aging on Researchers' Publication and Citation Pattern. PLoS ONE, vol. 3 , no 12 , pp. 40-48.

Glanzel W., Moed H.F. (2002) Journal Impact Measures in Bibliometric Research. Scientometrics, vol. 53, no 2, pp. $171-193$.

Goldfinch S. (2003) Investing in Excellence? The Performance-based Research Fund and its Implications for Political Science Departments in New Zealand. Political Science, vol. 55, no 1, pp. 39-55.

Gordon N.J., Nucci L.P., West C.K., Hoerr W.A., Uguroglu M.E., Vukosavich P., Tsai S.-L. (1984) Productivity and Citations of Educational Research: Using Educational Psychology as the Data Base. Educational Researcher, vol. 13, no 7, pp. 14-20.

Haas E., Wilson G.Y., Cobb C.D., Hyle A.E., Jordan K., Kearney K.S. (2007) Assessing Influence on the Field: An Analysis of Citations to Educational Administration Quarterly, 1979-2003. Educational Administration Quarterly, vol. 43, no 4, pp. 494-512.

Heckman J.J., Cameron S. (2001) The Dynamics of Educational Attainment for Blacks, Whites and Hispanics. Journal of Political Economy, vol. 109, no 3, pp. 455-499.

Hesli V.L., Lee J.M. (2011) Faculty Research Productivity: Why Do Some of our Colleagues Publish More than Others? Political Science \& Politics, vol. 44, no 2, pp. 393-408.

Hicks D., Tomizawa H., Saitoh Y., Kobayashi S. (2004) Evolving Indicators, Bibliometric Techniques in the Evaluation of Federally Funded Research in the United States. Research Evaluation, vol. 13, no 2, pp. 78-86.

Hesli V.L., Lee J.M. (2011) Faculty Research Productivity: Why Do Some of Our Colleagues Publish More than Others? Political Science \& Politics, vol. 44, no 2, pp. 393-408.

Kroc R.J. (1984) Using Citation Analysis to Assess Scholarly Productivity. Educational Researcher, vol. 13, no 6, pp. 17-22.

Ladd E.C., Lipset S.M. (1979) The 1977 Survey of the American Professoriate. Chronicle of Higher Education, vol. 17, no 18, pp. 7-8.

Larivière V., Macaluso B., Archambault É., Gingras Y. (2010) Which Scientific Elites? On the Concentration of Research Funds, Publications and Citations. Research Evaluation, vol. 19, no 1, pp. 45-53.

Lehman H.C. (1953) Age and Achievement, Princeton, NJ: Princeton University Press.

Levin S.G., Stephan P. (1998) Gender Differences in the Rewards to Publishing in Academe: Science in the 1970's. Sex Roles, vol. 38, no 11/12, pp. 1049-1064.

Lindsey D. (1978) The Scientific Publication in Social Science, San Francisco, CA: Jossey-Bass.

Luce T., Johnson D. (1978) Rating of Educational and Psychological Journals. Educational Researcher, vol. 7, no 10, pp. 8-10.

Marinova D., Newman P. (2008) The Changing Research Funding Regime in Australia and Academic Productivity. Mathematics and Computers in Simulation, vol. 78, no 2-3, pp. 283-291.

Mayo C.R., Zirkel P.A., Finger B.A. (2006) Which Journals are Educational Leadership Professors Choosing? Educational Administration Quarterly, vol. 42, no 5, pp. 806-811.

Moed H.F. (1996) Differences in the Construction of SCI Based Bibliometric Indicators among Various Producers: A First Overview. Scientometrics, vol. 35, no 2, pp. 177-191.

Mortimore P. (1999) Does Educational Research Matter? British Educational Research Journal, vol. 26, no 1, pp. 5-24.

Orr M. (2004) Political Science and Education Research: An Exploratory Look at two Political Science Journals. Educational Researcher, vol. 33, no 5, pp. 11-16.

Ouimet M., Bédard P.-O., Gélineau F. (2011) Are the H-Index and Some of Its Alternatives Discriminatory of Epistemological Beliefs and Methodological Preferences of Faculty Members? The Case of Social Scientists in Quebec. Scientometrics, vol. 88, no 1, pp. 91-106.

Piaget J. (1972) L'Épistémologie Génétique. Paris: Presses universitaires de France.

Sieber S.D. (1966) The Organization of Educational Research. New York, NY: Columbia University, Bureau of Applied Social Research.

Smart J.C., Elton C.F. (1981) Structural Characteristics and Citation Rates of Education Journals. American Educational Research Journal, vol. 18, no 4, pp. 399-413.

Smith N.L., Caulley D.N. (1981) The Evaluation of Educational Journals Through the Study of Citations. Educational Researcher, vol. 10, no 5, pp. 11-24.

Turner L., Mairesse J. (2003) Explaining Individual Productivity Differences in Scientific Research Productivity: How Important are Institutional and Individual Determinants? An Econometric Analysis of the Publications of French CNRS Physicists in Condensed Matter: 1980-1997 (Working Paper), University of Sorbonne, France.

Walberg H.J. (1972) University Distinction in Educational Research: An Exploratory Survey. Educational Researcher, vol. 1, no 1, pp. 15-16. Walberg H.J., Rasher S.P., Mantel H. (1977) Eminence and Citations in Educational Psychology. Educational Researcher, vol. 6, no 3, pp. 12-13. Walberg H.J., Vukosavich P., Tsai S.L. (1981) Scope and Structure of the Journal Literature in Educational Research. Educational Researcher, vol. 10, no 8, pp. 11-13.

West C.K. (1978) Productivity Ratings of Institutions Based on Publications in Journals of the American Educational Research Association: 1970-1976. Educational Researcher, vol. 7, no 2, pp. 13-14. 


\section{Особенности участия малых предприятий в международной научно-технической кооперации: опыт российско-германских контактов ${ }^{1}$}

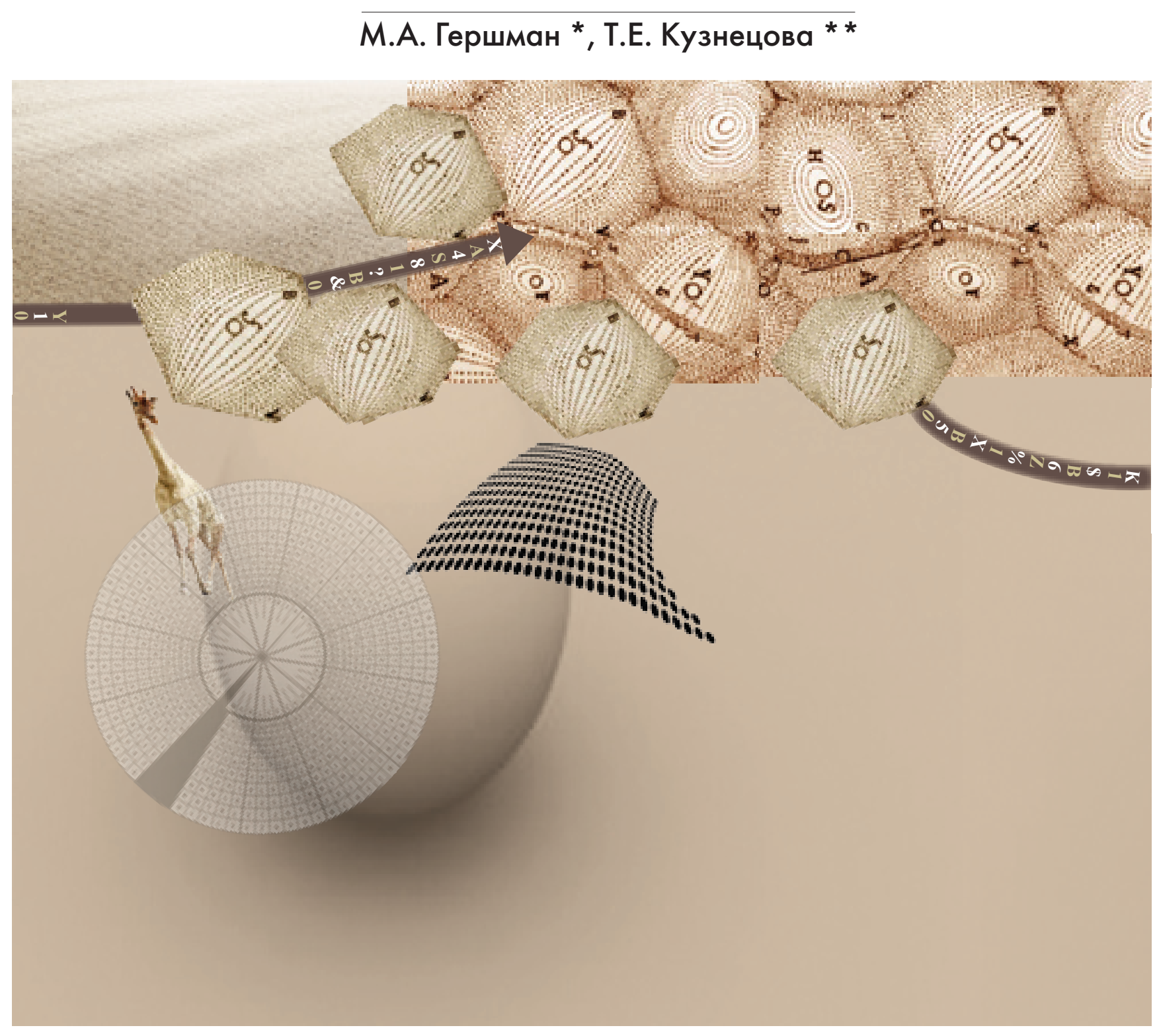

В развитии международной кооперации в научно-технологической сфере важную роль играют малые инновационные предприятия, оперативно приспосабливающиеся к изменчивым рыночным условиям.

В России активность подобных компаний на инновационном «поле», особенно в международном контексте, не столь заметна. Дефицит информации в этом направлении отчасти восполняют специализированные обследования. Результаты одного из них представлены в статье.
* Гершман Михаил Анатольевич — старший научный сотрудник. E-mail: mgershman@hse.ru

** Кузнецова Татьяна Евгеньевна - директор Центра научно-технической, инновационной и информационной политики, заместитель заведующего Лабораторией экономики инноваций. E-mail: tkuznetzova@hse.ru

Институт статистических исследований и экономики знаний НИУ ВШЭ

Адрес: Национальный исследовательский университет «Высшая школа экономики», 101000, Москва, Мясницкая ул., 20

\section{Ключевые слова}

малое инновационное предприятие;

международная научно-техническая кооперация; инновационная активность;

стимулы и барьеры сотрудничества.

Статья подготовлена на базе результатов, полученных в рамках проектов: «Глобализация научных исследований и разработок и научно-техническое сотрудничество между германскими и российскими предприятиями» (грант Международного бюро Федерального министерства образования и науки Германии (Internationales Büro des Bundesministeriums für Bildung und Forschung)) и «Выполнение работ по исследованию ключевых тенденций, особенностей и механизмов научно-технической кооперации отечественных малых предприятий и немецких компаний, осуществляющих экономическую деятельность в России» (при поддержке Фонда содействия развитию малых форм предприятий в научно-технической сфере). 


\section{Концептуальные рамки исследования}

Переход национальной экономики к росту на основе инноваций требует существенных трансформаций в большинстве секторов. Это необходимо для последовательного замещения неэффективной «сырьевой» модели, диверсификации отраслевой структуры, стимулирования опережающего развития высокотехнологичных отраслей, повышения инновационной активности предприятий. Решение подобных задач невозможно без правильной расстановки акцентов политики, в том числе с учетом лучшего зарубежного опыта.

В последние десятилетия произошел заметный сдвиг в понимании моделей развития инновационных систем и связей между их субъектами. Если ранее доминировавший классический подход был основан на центральной роли национальных инновационных систем в развитии экономики отдельных стран, то впоследствии получили распространение концепции, выходящие за рамки тех или иных государств и регионов [Freeman, 2002]. Глобализация в значительной степени нивелировала роль национальных систем: сегодня необходимо адаптировать инструменты инновационной политики к международному контексту [Borras et al., 2009]. Другая актуальная тенденция выразилась в переходе от линейных инновационных моделей к концепциям открытых инноваций [Chesborough, 2003, 2006] и сетевого взаимодействия на межстрановом уровне [OECD, 2008]. В основе указанных подходов лежит идея максимизации инновационного потенциала участников сетей за счет устойчивых партнерских связей, обеспечивающих доступ к необходимым ресурсам и улучшающих процесс трансфера знаний и технологий [Powell, Grodal, 2005]. Поскольку инновационные процессы приобретают глобальный характер, успешные исследовательские организации и предприятия все чаще выступают агентами международного сотрудничества. Это касается и малых инновационных предприятий (МИП), которые, создавая новые рабочие места, вносят существенный вклад в экономический рост и конкурентоспособность стран [Audretsch, 2009; OECD, 2012; Siegel et al., 2003]. В быстрорастущих секторах (информационно-коммуникационные технологии (ИКТ), автомобилестроение, фармацевтика) они выступают в качестве основных генераторов идей, которые в дальнейшем интегрируются в существующие продукты либо приобретаются крупными компаниями [OECD, 2006a].

Вместе с тем эта категория субъектов оказывается наименее защищенной. Несовершенство институциональных условий и финансовых систем зачастую ограничивает доступ таких предприятий к инвестициям и кредитным ресурсам, необходимым для осуществления инновационных проектов. В частности, кредитные ставки для малого и среднего бизнеса порой превышают стоимость банковских займов для крупных компаний [OECD, 2012], что не только снижает возможности роста МИП, но ставит под вопрос их способность к «выживанию»[Blanchflower, Oswald, 1998; World Bank, 2010].

Если ранее государства недооценивали роль МИП в инновационных процессах, то за последние двадцать лет приоритеты в большинстве стран были существенно пересмотрены и разработаны специальные инструменты политики. Так, в Великобритании с малыми инновационными предприятиями заключаются контракты на исследования и разработки (ИиР), а также размещается госзаказ на их инновационную продукцию; в Нидерландах используются «инновационные ваучеры», а во Франции - система специальных налоговых и социальных льгот. Южная Корея не так давно расширила техническую и финансовую поддержку этого типа компаний, разрешив использовать технологии (права на интеллектуальную собственность) в качестве залога для получения банковского кредита, и открыла программы субсидирования [World Bank, 2010]. Во многих регионах распространены косвенные меры поддержки: развитие бизнес-инкубаторов, венчурного финансирования, механизмов частногосударственного партнерства (например, в Италии более эффективными представляются именно опосредованные инструменты [Colombo, Grilli, 2008]).

В странах с развитой экономикой государство стремится обеспечить МИП поддержку не только на ранних стадиях роста, но и в процессе их инкорпорирования и выхода на международный рынок. Приоритетными инструментами политики здесь выступают услуги по консультированию, специальному обучению, финансированию маркетинговых кампаний и мероприятий, связанных с защитой интеллектуальной собственности [OECD, 2006b, 2007]. Важную роль на данном этапе играют торговые ассоциации, высокотехнологичные кластеры и программы поддержки сетевой кооперации (в США, Дании, Чили и др.). Последние актуальны и для России в контексте встраивания отечественных фирм в производственные цепочки создания добавленной стоимости, в том числе на базе локализованных производств.

Если принять во внимание текущее состояние научно-технологического комплекса России ${ }^{2}$, становится очевидным, что его потенциал не позволяет полностью достичь поставленных амбициозных целей развития страны ${ }^{3}$ В связи с этим важное значение приобретает интенсивная адаптация передового зарубежного опыта - реализация совместных научно-технологических проектов и программ, развитие международной торговли инновационной и высокотехнологичной продукцией и др. ${ }^{4}$ Очевидной потребностью является и разработка специальных инструментов государственного регулирования, на-

Имеются в виду технологическая отсталость значительной части производств, старение опытной и экспериментальной базы, дефицит квалифицированных специалистов и инженеров, квалификационные и возрастные диспропорции в их структуре и др.

Подразумеваются, в частности, цели, обозначенные в указах Президента Российской Федерации от 07.05.2012 г. № 596 «О долгосрочной экономической политике» и № 599 «О мерах по реализации государственной политики в области образования и науки», других документах государственной политики.

${ }^{4}$ Подробный анализ этих трендов проведен в работах [Глазьев, 2010; Гохберг, Кузнецова, 2011; Гохберг и др., 2011; OECD, 2011a, b] и других публикациях. 
правленных на поддержку международного сотрудничества и выхода отечественных предприятий на глобальный рынок.

Германия занимает наиболее устойчивые позиции во внешних торгово-экономических связях с Россией ${ }^{5}$.

- Удельный вес в российском внешнеторговом обороте стабильно составляет 8-9\% (доля нашей страны в торговом обороте Германии - 2.5\%).

- Объем инвестиций в национальную экономику в 2010 г. достиг почти 10.5 млрд долл.

- Число предприятий с германским участием, представленных ныне в 80 из 83 субъектов РФ, в 2011 г. превысило 6000 и демонстрирует устойчивый рост.

- В структуре российского экспорта в Германию доминируют энергоносители. Доля продукции топливно-энергетического комплекса в его общем объеме достигла в 2011 г. 82\%, металлов и металлических изделий - 9.1\%.

- В структуре отечественного импорта из Германии преобладает высокотехнологичная продукция; машины, оборудование и транспортные средства составляют около $60 \%$ импортируемых в Россию товаров, работ, услуг.

- Для российско-германской кооперации эффекты мирового финансово-экономического кризиса оказались достаточно мягкими: ни один инвестируемый проект не был заморожен; продолжает расти число совместных производств и представительств германских компаний на территории России.

Все это позволяет Германии претендовать на роль одного из ключевых партнеров России в области модернизации отраслей промышленности, инфраструктуры, инновационной сферы. Двусторонняя кооперация характеризуется не только экстенсивным ростом, но и высоким качеством интеграции. Так, в течение последних пяти лет в нашей стране были основаны современные производства, открыты специализированные учебные центры (в основном технического профиля) по подготовке персонала, «пилотные» исследовательские центры.

Научно-технологическое сотрудничество развивается как на двухсторонней основе, так и в форме реализации многосторонних проектов по направлениям 7-й Рамочной программы Европейского Союза по исследованиям, технологическому развитию и демонстрационной деятельности. В 2011-2012 гг. в рамках «Российско-германского года науки» было реализовано значительное число коммуникационных мероприятий, объединяющих научно-технологических и промышленных контрагентов из России и Германии, программ грантовой поддержки совместных исследовательских проектов.

На фоне динамичного развития международных контактов немаловажное значение приобретает оценка их эффективности и результативности с исполь- зованием информации, полученной непосредственно от участников этих процессов, в том числе малых инновационных компаний. Подобные сведения, безусловно, полезны в контексте практических аспектов поддержки российско-германской научно-технической кооперации с участием малых фирм; расширения возможностей распространения и тиражирования успешного опыта; выявления актуальных барьеров и формирования рекомендаций по их преодолению ${ }^{6}$.

Как показывает зарубежный опыт, создание благоприятной среды и инфраструктуры для малых предприятий является обязательным условием перехода на инновационную модель экономического роста. Без его наличия нельзя говорить о завершенности, эффективности национальной инновационной системы, следовательно, невозможно активизировать процессы инициирования и диффузии инноваций, распространять результаты интеллектуальной деятельности. Хотя в современных экономиках импульс инновациям (и их основной объем) дает, как правило, крупный бизнес, малые компании обеспечивают оперативную «обкатку» нововведений перед массовым внедрением [OECD, 2010a,b; Митин, 2010; Нестеренко, 2006].

В России сегмент малого высокотехнологичного бизнеса пока достаточно узок. Удельный вес МИП, осуществлявших технологические инновации, колеблется на уровне 4\% от общего числа малых компаний. При этом наблюдается высокая вариация по видам экономической деятельности: в производстве изделий медицинской техники и приборов аналогичный показатель составляет 14\%; фармацевтической продукции и вычислительной техники - 12\%. Как правило, малый бизнес не имеет средств, научной базы, квалифицированных кадров, резерва времени для освоения новых технологических процессов и окупаемости затрат. Подобные ограничения возникают даже при реализации небольших нововведений (не говоря уже о радикальных новациях). Иными словами, роль МИП в инновационном развитии в нашей стране пока незначительна и несопоставима с позициями в развитых государствах, например, в Германии [Гохберг, Кузнецьова, 2009, с. 33].

Внимание, уделяемое сегодня российским государством внедрению современных механизмов трансфера технологий в рамках международной кооперации, явно недостаточно, причем это касается как развития текущих процессов, так и возможностей их поддержки. Роль малых предприятий в научнотехнологической цепочке российско-германского партнерства, очевидно, недооценивается, учитывая позитивные эффекты от участия МИП в интернациональной кооперации и положительную корреляцию между результативностью их деятельности и активностью в сфере международного сотрудничества [Ahvenharju et al., 2006; European Commission, 2010]. Нестабильность глобальной экономики и внутренние проблемы двух стран создают предпосылки

\footnotetext{
Источники: Германия. Обзор торговых отношений с РФ (портал внешнеэкономической информации Министерства экономического развития Российской Федерации; http://www.ved.gov.ru); Бёльманн Й. Новый рост количества немецких предприятий в России (портал Российско-германской внешнеторговой палаты; httр:// russland.ahk.de/uploads/media/2011_01_13_deutscheUnternehmen_ru.pdf).

${ }^{6}$ Развитие данного направления инновационной политики рекомендовано экспертами при подготовке предложений по новой стратегии социально-экономического развития России на период до 2020 г. (Стратегии-2020) [Гохберг, Кузнецова, 2011]
} 
для возникновения дополнительных барьеров, препятствующих развитию такого взаимодействия. С учетом сказанного, необходимо осознание текущих ожиданий германских и российских предприятий и организаций, в целях упреждения факторов, способных оказать негативное влияние на кооперационные процессы. В то же время исследование успешных практик российско-германского сотрудничества с участием малых предприятий позволит выявить положительные характеристики выбранных схем для их дальнейшего тиражирования.

В конечном счете, наличие актуальной информации ${ }^{7}$, характеризующей особенности взаимодействия российских и германских малых предприятий в сфере науки и инноваций, позволит выработать полезные рекомендации по формированию действенных инструментов регулирования для обеих стран.

Такая работа была проведена в ИСИЭЗ НИУ ВШЭ по заказу и при поддержке Фонда содействия развитию малых форм предприятий в научнотехнической сфере. С 2008 г. Фонд совместно с Международным бюро Федерального министерства образования, науки, исследований и технологий Германии (Bundesministerium für Bildung und Forschung, BMBF) реализует специальную российскогерманскую программу в области прикладных исследований и инноваций. Объем финансирования, выделяемый Фондом на один проект, составляет до 4 млн руб. сроком на 1.5-2 года. За время существования программы были поддержаны 50 заявителей из примерно 150 полученных заявок ${ }^{8}$. Фонд берет на себя финансирование российского малого инновационного предприятия, а $\mathrm{BMBF}$ - консорциума участников из Германии (малое предприятие и исследовательская организация).

Проблемы научно-технической кооперации российских МИП - участников программы с германскими компаниями и научными организациями были изучены на основе обобщения результатов обследования, проведенного в формате глубинных интервью. Его участниками стали российские МИП, получившие финансирование по соответствующей программе Фонда в 2008-2010 гг. География респондентов охватывала такие города, как Москва, Королев, Саратов, Калуга, Кольцово, Казань. Выбранные для опроса компании представляли секторы, для которых характерно наиболее интенсивное сотрудничество с Германией: медицина, приборостроение, ИКТ, нанотехнологии. Интервью проводилось в формате очной либо телефонной беседы с руководителями предприятий. Гайд интервью предусматривал обсуждение вопросов, связанных со спецификой деятельности компаний; результативностью конкретных проектов, поддержанных Фондом; проблемами, барьерами, опытом и перспективами развития двухсторонних отношений. Для получения дополнительной информации были также опрошены несколько германских компаний, осуществляющих научно-техническую и инновационную деятельность и сотрудничающих с российскими МИП.
В статье представлены основные результаты опроса и кейсы, описывающие деятельность отдельных МИП. В соответствии с поставленными задачами основное внимание уделено стимулам и проблемам развития партнерства, а также эффективности его поддержки.

\section{Стимулы к международному научно- техническому сотрудничеству}

В ходе обследования респондентам задавались вопросы о стимулах для развития российско-германских отношений в научно-технологической сфере. По мнению большинства руководителей МИП, ключевой здесь можно считать возможность выхода на европейский рынок, что в одиночку сделать крайне сложно из-за проблем коммерциализации результатов на европейском пространстве, а также недоверия к незнакомым российским компаниям у европейских контрагентов.

«Они [европейцы], к сожалению, с настороженностью относятся, когда чисто российская компания без всякой поддержки западных стран пытается выйти на европейский рынок». генеральный директор малого предприятия сферы биомедицины.

Главным преимуществом германских научных организаций и фирм, работающих в научно-технической сфере, является наличие современного оборудования, которого зачастую нет в России. Об этой характерной и существенной для получения научнотехнических результатов особенности германских коллег чаще всего упоминалось в интервью с руководителями отечественных фирм медицинского профиля. В связи с этим именно в данной сфере германский партнер, как правило, выступает в качестве аналитического центра, проводящего научное моделирование, математические расчеты и др., а российский - занимается непосредственно прикладными исследованиями и разработками. Такого рода взаимодействие происходило, например, между ООО «Наноструктурированные технологии стекла» и Институтом прикладной фотоники (Institute for Applied Photonics), г. Берлин, при разработке стеклянного волокна, использующегося в биологических сенсорах для определения токсичности патогенных сред (холеры, туберкулеза и др.) на основании показаний оптических спектров. Российская сторона разрабатывала волокно, а немецкие ученые производили измерения с целью оценки достигнутых результатов.

«У них [немцев] есть превосходная материально-техническая база, которая нам и не снилась». руководитель российско-германского исследовательского проекта в сфере нанотехнологий.

Впрочем, отечественные МИП, работающие в других областях, также предпочитают брать на себя именно прикладные задачи. Возможно, подобная кооперация является следствием определенного глобального дефицита прикладных научно-технических решений.

\footnotetext{
Регулярная статистическая отчетность по этому направлению в России пока отсутствует.

${ }^{8}$ См. материалы Интернет-сайта Фонда содействия развитию малых форм предприятий в научно-технической cфере - http://www.fasie.ru.
} 
В этом смысле адекватно сформулированная задача, подразумевающая работу с ожидаемым и понятным прикладным результатом, всегда служит стимулом к сотрудничеству. Так, ООО «Аэросервис» совместно с коллегами из Института им. Фридриха-Александра (Friedrich-Alexander-Universität Erlangen-Nürnberg, FAU) осуществляли поиск материалов, которые могли бы использоваться в целях инактивации вредоносных микроорганизмов на поверхности фильтрующих материалов. При этом немецкая сторона разрабатывала аналитическую модель, позволяющую сузить диапазон поиска, а российская - обеспечивала экспериментальную составляющую.

Как показали результаты опроса, в большинстве случаев преимуществом германских коллег являются именно научно-исследовательские компетенции, научная школа, что не удивительно, учитывая многолетние традиции, менталитет и мощную поддержку национальной науки. Поскольку в России по многим направлениям такие компетенции отсутству ют, то эффекты от кооперации для отечественных МИП могут быть желательными и ощутимыми. Так, сотрудникам ООО «Научно-исследовательский центр высоких технологий» (НИЦВТ) ${ }^{9}$ удалось найти партнера для реализации совместного проекта в области наномодификации листовых материалов в Дрезденском техническом университете (Dresden Technical University).

Мотивы сотрудничества германской стороны с российскими предприятиями оценивались респондентами неоднозначно. Некоторые руководители считают, что у Германии все-таки имеется интерес к российским научным школам, сохранившимся еще с советских времен, высокому исследовательскому потенциалу. По оценкам опрошенных, российскую научную школу в отдельных случаях удалось сохранить именно в малых компаниях, напрямую или косвенным образом связанных с институтами Российской академии наук. Как правило, специалисты таких фирм по совместительству работают и в академических институтах.

Ряд участников опроса полагает, что европейская научная система не нацелена на коммерциализацию результатов ИиР, в отличие, например, от американской, где существует мощная инфраструктура, «заточенная» под инновации (Кремниевая Долина и др.). Это становится дополнительным стимулом к поиску партнеров, способных получить прикладные научные результаты и довести их до конечного продукта. В России, по мнению некоторых представителей медицинских кругов, как раз имеется необходимый научный задел при относительно низкой стоимости аналогичных разработок.

Особый интерес для германских компаний представляет российский рынок, на котором имеется много свободных ниш. Можно утверждать, что реализация совместных исследовательских проектов с малыми фирмами является для иностранных партнеров своего рода инструментом мониторинга, «прощупывания» рынка.

\section{Барьеры кооперации}

Основные причины, препятствующие продуктивным контактам российских МИП с зарубежными партнерами, кроются, по мнению респондентов, в не слишком благоприятных общих условиях хозяйствования и отсутствии внятной политики. Однако более охотно опрошенные обсуждали конкретные проблемы и пробелы действующей нормативной правовой базы, особенности административной практики.

Одной из серьезных проблем, которые беспокоят и российские компании, и их германских партнеров, остаются жесткие рамки таможенного законодательства. Этот барьер особенно актуален для инновационных предприятий медицины, работающих с биологическими материалами, химическими веществами и компонентами для высокотехнологичного оборудования, а также компаний, занимающихся машиностроением. Речь идет, в частности, о действующих пошлинах на импорт материалов и комплектующих из-за рубежа при возможности беспошлинного ввоза готового оборудования, не имеющего российского аналога. Существующий порядок не только ограничивает возможности отечественных производителей, но и снижает мотивацию германских компаний, размещающих производства на территории страны. Кроме того, отмечаются сложности бюрократического характера, к которым относятся излишний объем документации, длительные сроки и высокая стоимость таможенных процедур. Зачастую барьеры выражаются в том, что опытные образцы продукции «блокируются» при пересечении границы. Вопрос об изменении таможенного законодательства стоит для научных организаций и высокотехнологичных предприятий настолько остро, что не раз выносился на уровень Президента России и Правительства, однако из-за негибкости управленческой «машины» и сопротивления отдельных групп бюрократии остается нерешенным.

«У нас один проект был (заказ, связанный с электроникой), когда мы не смогли ни привезти, ни отправить необходимые элементы. Таможня мешает!». генеральный директор малой фирмы - произбодителя медицинского оборудования.

Другая проблема, связанная с патентованием научных результатов за рубежом, также обусловлена недоверием к российским компаниям, которое усиливается информацией о высоком уровне коррупции в стране. Нередки случаи, когда европейские патентные ведомства существенно затягивают сроки экспертизы заявок и даже отказывают в регистрации прав на интеллектуальную собственность. Часто единственным надежным способом считается патентование разработок иностранным партнером (в совместную собственность) $)^{10}$, что не всегда выгодно для россиян. К тому же процедура международной

\footnotetext{
${ }^{9}$ Малое предприятие при Казанском национальном исследовательском техническом университете им. А.Н. Туполева.

${ }^{10}$ Именно таким образом действует ряд опрошенных малых предприятий.
} 
регистрации прав на интеллектуальную собственность воспринимается в России как излишне сложная и дорогостоящая. Поскольку она и на самом деле такова, поддержка государства, как заметил один из респондентов, «точно не была бы лишней».

«Поскольку в России очень сложно получить международные патенты, мы планируем запатентовать результаты вместе с зарубежными коллегами». руководитель малого предприятия сферы медицины.

Серьезным барьером для российских фирм является законодательство о государственных закупках, которое, по словам опрошенных, тормозит внедрение новых разработок, лишая отечественных инноваторов возможности конкурировать с зарубежными производителями даже на территории собственной страны. Известно, что процесс коммерциализации технологий требует существенных денежных и временных ресурсов (для запуска серийного производства, маркетинга, совершенствования продукта, организации продаж), которые, как правило, у МИП отсутствуют. Государственная политика в сфере закупок инновационной продукции могла бы стать эффективным инструментом стимулирования ${ }^{11}$. Но этого не произошло. Более того, она оценивается респондентами не иначе как «абсурдная»: выделяются бюджетные средства на реализацию научных исследований, однако на последующих стадиях процесса российские разработки не поддерживаются. Вместо них государством закупаются зарубежные продукты-аналоги ${ }^{12}$. Такой подход властей фактически отправляет малые (и не только) инновационные предприятия в «свободное плавание», обрекая на самостоятельный поиск инвесторов, что в России остается нелегкой задачей. В то же время передовые отечественные разработки достаются зарубежным покупателям. Так, технология системы управления грузами и мониторинга их передвижения, аналогичная разработке ООО «Век-21», своевременно не поддержанной государством, вскоре была реализована компанией Lufthanza Cargo на одном из ее предприятий.

«Сложилась абсурдная ситуация - государство выделяет значительные средства на ИиР, но не заинтересовано в приобретении готового продукта. Как в таких условиях конкурировать с Западом?». руководитель малого предприятия - производителя диагностического оборудования.

«Пока мы ищем инвестора в России, зарубежные компании уже используют наши разработки». руководитель малого предприятия сферы ИКТ.
Соглашаясь с необходимостью обеспечения конкуренции при заключении государственных контрактов, руководители МИП (в частности $3 \mathrm{AO}$ «Научнопроизводственная фирма ДНК-Технология») подчеркивают принципиальную важность создания специальных инструментов закупок инновационной продукции у российских производителей ${ }^{13}$. Это позволит трансформировать разработки в инновации, внедрить их в реальный сектор экономики, сформировать устойчивый потребительский спрос и повысить конкурентоспособность. Целесообразность подобных мер обусловлена еще и тем, что при наличии отдельных видов продукции, не уступающей по качеству западным аналогам, у отечественных предприятий практически отсутствуют возможности снижения себестоимости ${ }^{14}$.

Среди общих проблем государственного регулирования в сфере инноваций отмечалось отсутствие инструментов лоббирования российских разработок, что проявляется в низкой лояльности к ним за рубежом. В этой связи интересен опыт Китая, долгие годы инвестировавшего в собственный бренд («made in P.R.C.», «made in China») и, в итоге, добившегося значительных результатов [Fan, 2006]. В России подобными проектами власти фактически не занимаются, хотя эта тема не раз поднималась на различных уровнях.

Многочисленные проблемы связаны со слабостью производственной и инжиниринговой инфраструктуры; неразвитостью практики аутсорсинга отдельных видов деятельности; нехваткой опыта проектирования и дизайна и др.

Результаты опроса показывают, что барьеры кооперации имеют заметные отраслевые отличия. Так, в сфере медицины действует достаточно жесткая система государственной регистрации (например, в отношении новых методов диагностики), по словам респондентов, представляющая собой длительный бюрократический процесс. За время ее прохождения рыночные возможности могут быть упущены, а новая разработка - скопирована конкурентами. В Германии, в отличие от России, врач вместе с лицензией на тот или иной вид деятельности получает право применять новые диагностические системы (под собственную ответственность) без прохождения сложной процедуры согласования с государством. В нашей стране он может использовать только нормативно утвержденные препараты и системы. При этом фактически отсутствует страхование врачебной ответственности: если врач действовал в соответствии с нормативными документами, формально ответственности он не несет ${ }^{15}$.

\footnotetext{
11 По примеру Китая, где подобная политика проводилась целенаправленно [Хие, 2012].

12 При формальном соответствии федеральному законодательству о государственных закупках, предусматривающему проведение конкурсных процедур.

13 Задача повышения инновационности государственных закупок, изменения механизмов их реализации, учета специфики закупаемой продукции и т. д. активно обсуждалась экспертами в рамках разработки Стратегии-2020. Результатом стал ряд предложений по развитию этого механизма, повышению его эффективности, восприимчивости к новым знаниям и технологиям [Гохберг, Кузнецова, 2011].

${ }^{14}$ Отметим такие факторы, как дефицит квалифицированных технических и инженерных кадров, необходимость ввозить практически все электронные компоненты для производимого оборудования из-за рубежа, высокие накладные расходы и т. д.

15 По мнению экспертов, Федеральный закон от 21 ноября 2011 г. № 323-Ф3 «Об основах охраны здоровья граждан в Российской Федерации» существенно ограничивает возможности страхования врачебной ответственности. В настоящее время рассматривается законопроект, планируемый к принятию в 2013 г., который должен способствовать разрешению данной проблемы [Кондратюк, 2012].
} 


\section{«Старт» совместных проектов}

Значимым фактором в развитии международной научно-технической кооперации считаются особенности установления первичного контакта с зарубежными партнерами. Одним из механизмов, инициирующих сотрудничество, считаются международные выставки, форумы и конференции. Так, ООО «НПО «Кристалл» ${ }^{16}$ «получило» будущего немецкого партнера на тематической выставке. Завязавшееся знакомство помогло малому российскому предприятию выйти на международный рынок и установить контакты с крупнейшими мировыми автопроизводителями (Porsche, BMW, Audi и др.). Другим, менее распространенным способом поиска зарубежного компаньона является так называемая «деловая разведка». В частности, ООО «ПТФ Гидран» прибегло к ней еще в 1990-х гг. Сегодня фирма совместно с немецкой стороной при поддержке Фонда работает над проектом адаптации импортного оборудования по очистке грунтовых вод к российским природным условиям. Источником значительной доли международных контактов выступают «старые связи», когда контактным лицом с зарубежной стороны выступает бывший соотечественник, эмигрировавший за рубеж. Именно таким образом развивалось сотрудничество с Германией у ряда респондентов.

\section{Господдержка кооперации}

В качестве рекомендаций по повышению эффективности международной кооперации в научнотехнической сфере интервьюируемые отмечали, в первую очередь, необходимость смягчения административных и экономических барьеров. К таковым относятся:

- облегчение и ускорение таможенных процедур, применение льгот на ввозимые компоненты и материалы;

- снижение налогообложения научно-исследовательских работ, упрощение налогового администрирования;

- отмена жесткого визового режима;

- создание базы данных потенциальных зарубежных партнеров в научно-технической сфере и обеспечение свободного доступа к ней. Многие руководители МИП подчеркивали в ходе опро$\mathrm{ca}$, что это позволило бы избежать неудачного опыта сотрудничества, расширить число международных контактов.

Малые предприятия, получившие финансирование со стороны Фонда, как правило, пользуются и другими возможностями государственной поддержки: участвуют в проектах федеральных целевых программ Минобрнауки России, региональных программ; планируют контактировать с институтами развития.

Однако инструментов, специально нацеленных на развитие научно-технической кооперации непосредственно с зарубежными партнерами, в том числе из Германии (помимо программы Фонда), опрошенные назвать не смогли (лишь один опрошенный упомянул программы совместных научных исследований Фонда Гете).

Что касается инструментов поддержки научной и инновационной деятельности в целом, то респондентами давались частные характеристики отдельных регулирующих мер. Так, представитель компании, резидента Новосибирского технопарка положительно оценил государственную программу «Создание в Российской Федерации технопарков в сфере высоких технологий» ${ }^{17}$. По его словам, здесь достаточно просто получить небольшие гранты на ИиР, отчетность по которым совсем не обременительна. На средства программы при льготных условиях кредитования компанией была организована физико-химическая лаборатория, закуплено необходимое научное оборудование. В результате удалось создать «научного подрядчика» не только для себя, но и других исследовательских команд, занимающихся приборостроением.

Не осталась незамеченной участниками опроса и активность Сколковского технологического университета. С одной стороны, скептически воспринимается политика государства по концентрации финансовых ресурсов вокруг Сколково, учитывая невыстроенность системы управления и распределения финансирования, традиционные российские коррупционные «беды».

«Они сами говорят: "Мы летим в самолете и одновременно прикручиваем крылья"». генеральный директор малого предприятия сферь медиицны - о Сколково.

С другой стороны, по мнению опрошенных, «Сколтех» является одним из немногих перспективных инструментов развития российского инновационного бизнеса. В значительной мере это обусловлено сотрудничеством с американскими специалистами из Массачусетсского технологического университета (Massachusetts Institute of Technology, MIT) - одного из мировых лидеров в научно-технологической сфере, включая инновационную направленность выполняемых исследовательских проектов.

Одним из примеров эффективного направления развития Сколковского университета названо концептуальное разделение труда ученого и предпринимателя. Здесь создаются и поддерживаются специальные структуры, ответственные за коммерциализацию научных разработок, включая серийное производство, маркетинг и сбыт.

«От ученых не требуется, чтобы они торговали. Перед ними стоит задача создать нечто патентоспособное, получить патент, и самостоятельно либо с чьей-то помощью продать лицензию». генеральный директор малого предприятия резидента Сколково

\footnotetext{
16 ООО «НПО «Кристалл» производит термоэлектрические охлаждающие и генераторные (Пельтье) модули, которые используются в автомобилестроении. Фирма побеждала в конкурсах российско-германской программы Фонда содействия развитию малых форм предприятий в научно-технической сфере в 2009 г.

17 Распоряжение Правительства РФ от 10 марта 2006 г. № 328-р (ред. от 27 декабря 2010 г.) «О государственной программе «Создание в Российской Федерации техно-
} парков в сфере высоких технологий». 
Неоднозначное отношение сложилось у респондентов и к так называемым «мегагрантам» ${ }^{18}$. С одной стороны, признается полезность для отечественной науки инициатив по привлечению ведущих ученых, передающих лучший зарубежный опыт российским коллегам. Мегагранты содействуют появлению новых источников научных знаний, стимулируют россиян работать в новых исследовательских областях. В то же время, отмечается непрозрачность процедуры организации конкурса.

Заметный разброс оценок среди респондентов наблюдается в отношении создания малых инновационных предприятий на базе вузов и научных организаций ${ }^{19}$. Некоторые опрошенные считают, что эти фирмы из-за несовершенства нормативной правовой базы и отсутствия реальных стимулов вряд ли смогут и будут заниматься инновациями.

\section{Отношение к программам Фонда}

Большинство респондентов положительно относятся к деятельности Фонда содействия развитию малых форм предприятий в научно-технической сфере, считают его работу полезной. Отдельные руководители МИП отмечают отсутствие коррупции и справедливый отбор победителей конкурсов. По мнению опрошенных, в целом, поддержка Фонда крайне результативна, даже при условии, что исследования не всегда завершаются созданием коммерческого продукта. Большинство проектов, поддерживаемых Фондом, обычно доводятся до некоего понятного результата, который затем несложно трансформировать в инновационный продукт.

«Фонд содействия - первая организация, демонстрирующая адекватный подход к анализу заявки». руководитель малой компании сферы электроэнергетики.

К слабым сторонам программ Фонда отнесены недостаточный размер грантов и избыточная отчетность, на которую приходится тратить много времени. В ряде случаев респонденты указывали на целесообразность повышения качества экспертизы конкурсных заявок с привлечением международных экспертов. Упоминалась и необходимость усиления информационной пропаганды конкурсов Фонда в целях расширения круга потенциальных участников.

«Фонд содействия «радует» системой отчетности. Она явно избыточна»

руководитель проекта малой инжиниринговой компании.

В ходе опроса выявилась ключевая проблема, связанная с позиционированием Фонда в системе институтов развития. По мнению респондентов, руководству Фонда следует четко определить его место в этой системе и ожидаемые результаты от проводимых конкурсов. Вместе с тем очевидно, что размер грантов, выдаваемых Фондом, позволяет покрыть лишь часть расходов на проведение ИиР (например, закупку оборудования), но никак не на дальнейшие мероприятия по продвижению инновационной продукции на рынок. В данных условиях крайне неубедительно выглядит требование Фонда по обязательному софинансированию работ со стороны малых предприятий, которые, как правило, испытывают дефицит денежных средств. Как заметили некоторые респонденты, средства для коммерциализации инновационных технологий целесообразно выделять через другие государственные институты развития, что, кстати, является (или должно являться) органичным составным элементом «инновационного лифта».

«Фонду необходимо ясно понимать, какое место он занимает в системе институтов развития и чем может оперировать в своей нише». генеральный директор малого предприятия сферы медиичины.

\section{Взгляд со стороны германских компаний}

Дополнительно обследовались несколько германских компаний, выполняющих ИиР на территории России и работающих в различных секторах экономики (медицина, производство строительных материалов, химическая промышленность и др. $)^{20}$. Выяснилось, что сотрудничество с российскими МИП в сфере науки и инноваций развито в недостаточной степени и лишь в определенных отраслях. Возможно, это стало следствием небольшой выборки, хотя ряд германских экспертов полагают, что подобная тенденция носит общий характер. Многие немецкие инновационные компании, действующие в России, не видят потенциальных выгод от сотрудничества с малым бизнесом. Отмечается также дефицит перспективных проектов и технологий. Даже в столь динамично развивающейся отрасли, как фармацевтика, крайне сложно найти отечественные разработки, интересные с точки зрения инвестиций и коммерциализации. Основные исследовательские компетенции по-прежнему сосредоточены в научных организациях, накопивших свой опыт в советское время, но сохранивших достаточно замкнутую модель функционирования [Гохберг и др., 2011; Кузнеиова, 2007, 2011].

«Малые предприятия с разработками приходили, но не сказать, что было что-то новое и мы были бы готовы сотрудничать». -

руководитель направления развития немецикого фармацевтического кониерна.

\footnotetext{
${ }^{18}$ Имеются в виду гранты, распределяемые в соответствии с Постановлением Правительства РФ от 9 апреля 2010 г. № 220 «О мерах по привлечению ведущих ученых в российские образовательные учреждения высшего профессионального образования».

19 В рамках федерального закона от 2 августа 2009 г. № 217-Ф3 «О внесении изменений в отдельные законодательные акты Российской Федерации по вопросам создания бюджетными научными и образовательными учреждениями хозяйственных обществ в целях практического применения (внедрения) результатов интеллектуальной деятельности».

20 Авторы выражают благодарность компаниям Knauf, Henkel, Stada, Bayer, Evonik за участие в интервью.
} 
Безусловно, развитию кооперации препятствует нехватка коммуникационных площадок и иных инфраструктурных кооперационных инструментов. Вместе с тем опрошенные немецкие компании намерены развивать инновационную деятельность в России; некоторые планируют создание структурных подразделений, ответственных за ИиР и инновации. Их основными партнерами, как правило, выступают научно-исследовательские институты и вузы (преимущественно в части подготовки кадров), которые, по мнению ряда респондентов, в последнее время пользуются ощутимой поддержкой со стороны госу дарства и стараются использовать данный потенциал.

«Университеты обладают идеями; благодаря государству у них появились ресурсы. Сегодня они уже не совсем оторваны от рынка». -

руководитель R\&D-направления немеикого химического холдинга.

Среди внешних экономических и политических проблем, волнующих инновационные германские компании в России, стоит вопрос защиты интеллектуальной собственности. Стремясь обезопасить свои интересы, они вынуждены тратить значительное время на согласование соответствующих пози ций договоров с российскими исследовательскими организациями. Респонденты считают назревшей необходимостью развитие инструментов повыше ния ответственности за нарушения в этой области и эффективного разрешения соответствующих спо ров в судебном порядке.

«Работаем с кем-то из третьих лиц не из нашей компании; разрабатываем продукт. Мы не можем гарантировать, что кто-то из внешней команды через определенное время не уйдет в другую компанию и не унесет наши разработки». -

руководитель R\&D-направления немецкой компании произбодителя строительных материалов.
Острым для германских фирм является и таможенный «вопрос»: завышенные ставки пошлин на ввозимые материалы и вещества, длительные сроки прохождения процедур, избыточный объем документации и высокая стоимость услуг.

Среди других общероссийских проблем чаще всего упоминаются ненадежность поставщиков материалов, слабо развитая система логистики, административное давление на бизнес. Существенным недостатком является отсутствие в ряде промышленных секторов системы сертификации, гармонизированной с международными стандартами и практикой. Иными словами, при наличии сертификатов международных центров компаниям требуются повторные аналогичные испытания в России. Отмечался и недостаток информации о текущей государственной политике в сфере науки и инноваций, возможных льготах и преференциях зарубежным компаниям.

\section{Совершенствование инструментов политики для развития международного сотрудничества}

Несмотря на сравнительно небольшой масштаб, опрос позволил частично преодолеть дефицит количественных и качественных данных, характеризующих совместную научно-техническую деятельность российских и зарубежных партнеров, факторы успеха реализуемых проектов, внешние и внутренние барьеры. Респонденты, как правило, недостаточно осведомлены о действующих инструментах государственной поддержки международного сотрудничества в научно-технической сфере. Практически единственной действенной мерой для большинства из них являются программы Фонда содействия развитию малых форм предприятий в научно-технической сфере и гранты зарубежных (в нашем случае - немецких) научных организаций

\section{Табл. 1. Предложения по совершенствованию инструментов государственной политики} в целях развития мехдународного научно-технического сотрудничества

\section{Финансирование}

и льготы

- Развитие существующих и создание новых программ международного сотрудничества в сфере науки и инноваций, аналогичных международным программам Фонда.

- Развитие механизмов двухстороннего совместного финансирования и кредитования малого инновационного бизнеса в России. Пример - российско-германский фонд поддержки высокотехнологичных, инновационных и энергоэффективных проектов малого и среднего бизнеса.

- Применение таможенных льгот для материалов и комплектующих, используемых в научно-технической и инновационной деятельности, а также на локализованных зарубежных производствах.

- Распространение опыта внедрения комплексных инструментов государствен ной поддержки («policy mix») и льгот предоставляемых резидентам Сколково, на успешные российские технопарки, открытые экономические зоны техниковнедренческого типа, наукограды, территориальные инновационные кластеры.

\section{Улучшение инновацион-} ной инфраструктуры

- Развитие консалтинговой инфраструктуры для поддержки зарубежных компаний, планирующих инновационную деятельность в России.

- Развитие инфраструктуры, обеспечивающей ускоренную регистрацию прав на интеллектуальную собственность за рубежом, спредоставлением льгот по оплате данных услуг российским МИП, включая совместную российскую и иностранную собственность.

- Развитие структур по коммерциализации разработок (в том числе на базе Сколковского технологического университета).

\section{Совершенствование}

«рамочных условий»

- Упрощение импорта технологий, путем корректировки устанавливаемых Правительством перечня оборудования, перемещение которого через таможенную границу РФ осуществляется без специального разрешения на ввоз, и правил использования.

- Совершенствование инструментов защиты прав на интеллектуальную собственность (в рамках новых судов по интеллектуальным правам).

- Упрощение миграционного законодательства в отношении квалифицированных иностранных специалистов, работающих в России.

- Предоставление изготовителям возможности выведения продукции на рынок под собственную ответственность с использованием декларирования вместо сертификации.

- Упрощение и ускорение процедур сертификации, приведение их в соответствие с международными стандартами качества.

- Развитие профессиональных объединений (ассоциаций) российских поставщиков. 
и фондов. Именно поэтому наиболее значимые рекомендации, полученные на основе систематизации результатов опроса, относятся, прежде всего, к деятельности Фонда содействия развитию малых форм предприятий в научно-технической сфере. Не удивительно, что чаще всего речь идет об увеличении объемов средств, выделяемых на реализацию кооперационных проектов.

Другие предложения по совершенствованию инструментов политики в основном ориентированы на преодоление существующих барьеров партнерства.
Для удобства они сгруппированы и представлены в табличной форме (табл. 1). Отметим, что ограниченный характер выборки не позволяет сделать серьезные обобщения. Каждую меру предлагали (или соглашались с ней, когда обсуждение инструмента регулирования инициировалось интервьюером) один-два респондента ${ }^{21}$. Тем не менее, складывается достаточно полная картина условий, необходимых для того, чтобы российские МИП превратились (по примеру развитых стран) в активных участников национальной инновационной системы.

Глазьев С.Ю. (2010). Стратегия опережающего развития России в условиях глобального кризиса. М.: Экономика.

Гохберг Л.М., Кузнецова И.А. (2009) Инновации в российской экономике: стагнация в преддверии кризиса? // Форсайт. Т. 3 . № 2.

С. $28-46$.

Гохберг Л.М., Кузнецова Т.Е. (2011) Стратегия-2020: новые контуры инновационной политики // Форсайт. Т.5. № 4. С. 40-46.

Гохберг Л.М., Кузнецова Т.Е., Королев В.А. (2011) Международная кооперация как императив современной инновационной политики //

Содружество независимых государств: пространство инноваций. М.: Центр стратегического партнерства. С. 41-49.

Грачева Г.А., Кузнецова Т.Е., Рудь В.А., Суслов А.Б. (2012) Инновационное поведение российских предприятий / под ред.

Л.М. Гохберга. М.: НИУ ВШЭ.

Кондратюк П. (2012) Правовые основы и практика применения страхования профессиональной ответственности // Финансовая газета. № 3. С. 11.

Кузнецова Т.Е. (2007) Переход на новые организационно-правовые формы: вызовы для государственных научных учреждений. Доклад на VIII международной конференции ГУ-ВШЭ «Модернизация экономики и общественное развитие», 3-5 апреля 2007 г., Москва.

Кузнецова Т.Е. (2011) Институциональные реформы в секторе исследований и разработок в России: снова в начале пути? //

ХI Международная научная конференция по проблемам развития экономики и общества / отв. ред. Е.Г. Ясин. Кн. 3. М.: НИУ ВШЭ. C. $575-584$.

Митин Ю.Р. (2010) Выбор стратегии развития для малых инновационных компаний // Креативная экономика. № 7 (43). С.57-61.

Нестеренко Ю.Н. (2006) Малый инновационный бизнес: новые подходы к эффективному развитию. М.: МПА-Пресс.

Такер Р. (2006) Инновации как формула роста: Новое будущее ведущих компаний. М.: Олимп-Бизнес.

Ahvenharju S., Syrjänen M., Hjelt M. (2006) International R\&D in high-growth SMEs — Implications to innovation policy. Helsinki: Gaia Group OY.

Audretsch D.B. (2009) From Knowledge to Innovation Resolving the "European Paradox" // Marklund G., Vonortas N.S., Wessner Ch.W. (eds.)

The Innovation Imperative. National Innovation Strategies in the Global Economy. Cheltenham: Edward Elgar Publishing.

Blanchflower D., Oswald A. (1998) What Makes an Entrepreneur // Journal of Labor Economics. Vol. 16. P. 26-60.

Borras S., Chaminade C., Edquist Ch. (2009) The Challenges of Globalization: Strategic Choices for Innovation Policy // Marklund G., Vonortas

N.S., Wessner Ch.W. (eds.) The Innovation Imperative. National Innovation Strategies in the Global Economy. Cheltenham: Edward Elgar Publishing.

Chesbrough H. (2003) Open Innovation. Cambridge, Massachusetts: Harvard Business Press.

Chesbrough H. (2006) Open Business Models. Cambridge, Massachusetts: Harvard Business Press.

Colombo M.G., Grilli L. (2008) Supporting High-Tech Start-ups: Lessons from Italian Technology Policy // Geenhuizen M., Trzmielak D.M.,

Gibson D.V., Urbaniak M. (eds.) Value Added Partnering and Innovation in a Changing World. Purdue University Press. P. 89-111.

European Commission (2010) Internationalisation of European SMEs. Luxembourg: EC DG Enterprise and Industry.

Fan Y. (2006) The Globalisation of Chinese Brands // Marketing Intelligence \& Planning. Vol. 24. № 4. P. 365-379.

Freeman C. (2002) Continental, national and sub-national innovation systems // Research Policy. № 31. P. 191-211.

World Bank(2010) Innovation Policy: A Guide for Developing Countries. Part II: Policy Functions. World Bank. P. 71-105.

OECD (2006a) Enhancing the Role of SMEs in Global Value Chains: Conceptual Issues Draft Report. Paris: OECD.

OECD (2006b) The Athens Action Plan for Removing Barriers to SME Access to International Markets. Paris: OECD.

OECD (2007) Enhancing the Role of SMEs in Global Value Chains. Tokyo: OECD.

OECD (2008) Open Innovation in Global Networks. Paris: OECD.

OECD (2010a) The OECD Innovation Strategy. Getting A Head Start on Tomorrow. Paris: OECD.

OECD (2010b) SMEs, Entrepreneurship and Innovation. Paris: OECD.

OECD (2011a) OECD Reviews of Innovation Policy. Russian Federation. Paris: OECD.

OECD (2011b) OECD Economic Review of the Russian Federation. Paris: OECD.

OECD (2012) Financing SMEs and Entrepreneurs 2012: An OECD Scoreboard. Paris: OECD.

Powell W.W., Grodal S. (2005) Networks of Innovators // Fagerberg J., Mowery D., Nelson R.R. (eds.) The Oxford Handbook on Innovation.

Oxford University Press. P. 57-85.

Siegel D., Wessner C., Binks M., Lockett A. (2003) Policies Promoting Innovation in Small Firms: Evidence from the U.S. and U.K. // Small

Business Economics. Vol. 25. P. 675-705.

Xue L. (2012) The Evolution of China’s Innovation System — Domestic Reform and Global Integration. Tsinghua University. 


\title{
Specificities of Involving Small Enterprises into International S\&T Co-operation: Evidence from the Linkages between Russia and Germany
}

\author{
Mikhail Gershman \\ Senior Research Fellow. E-mail: mgershman@hse.ru \\ Tatiana Kuznetsova \\ Director, Centre for S\&T, Innovation and Information Policy, and Deputy Head, Laboratory for Economics of Innovation. \\ E-mail: tkuznetzova@hse.ru
}

Institute for Statistical Studies and Economics of Knowledge, National Research University Higher School of Economics

Address: National Research University Higher School of Economics, 20, Myasnitskaya str., Moscow, 101000

\begin{abstract}
$\mathrm{S}$ uccessful practices around the world show that small innovative enterprises play an important role in developing international S\&T cooperation. Such enterprises adjust flexibly to the needs of producers and consumers of new knowledge and technologies, as well as the volatile market conditions. In Russia the presence of this type of enterprises on the innovation scene, especially in the international context, is not as visible as abroad.

Reliable data on their activity is virtually non-existent at the moment, but can be collected through special surveys.

This paper provides the results from a survey of Russian small enterprises involved into S\&T cooperation with German firms and organizations. It identifies the incentives and barriers to international S\&T cooperation and evaluates the efficiency of government support for such cooperation.
\end{abstract}

\section{Keywords}

small innovative enterprise; international S\&T co-operation; innovation performance; incentives and barriers for co-operation.

\section{References}

Ahvenharju S., Syrjänen M., Hjelt M. (2006) International R®D in High-Growth SMEs - Implications to Innovation Policy, Helsinki: Gaia Group OY.

Audretsch D.B. (2009) From Knowledge to Innovation Resolving the "European Paradox". The Innovation Imperative. National Innovation Strategies in the Global Economy (eds. G. Marklund, N. Vonortas, Ch. Wessner), Cheltenham: Edward Elgar Publishing.

Borras S., Chaminade C., Edquist Ch. (2009) The Challenges of Globalization: Strategic Choices for Innovation Policy. The Innovation Imperative. National Innovation Strategies in the Global Economy (eds. G. Marklund, N. Vonortas, Ch. Wessner), Cheltenham: Edward Elgar Publishing.

Blanchflower D., Oswald A. (1998) What Makes an Entrepreneur. Journal of Labor Economics, vol. 16, pp. 26-60.

Chesbrough H. (2003) Open Innovation, Cambridge, Massachusetts: Harvard Business Press.

Chesbrough H. (2006) Open Business Models, Cambridge, Massachusetts: Harvard Business Press.

Colombo M.G., Grilli L. (2008) Supporting High-Tech Start-ups: Lessons from Italian Technology Policy. Value Added Partnering and Innovation in a Changing World (eds. M. Geenhuizen, D.M. Trzmielak, D.V. Gibson, M. Urbaniak), Purdue University Press, pp. 89-111.

European Commission (2010) Internationalisation of European SMEs, Luxembourg: EC DG Enterprise and Industry.

Fan Y. (2006) The Globalisation of Chinese Brands. Marketing Intelligence \& Planning, vol. 24, no 4, pp. 365-379.

Freeman C. (2002) Continental, national and sub-national innovation systems. Research Policy, no 31, pp. 191-211.

Glazyev S. (2010). Strategiya operezhayushchego razvitiya Rossii v usloviyakh global'nogo krizisa [Russias Faster Growth Strategy in the Context of Global Crisis], Moscow: Ekonomika.

Gokhberg L., Kuznetsova I. (2009) Innovatsii v rossiiskoi ekonomike: stagnatsiya v preddverii krizisa? [Innovation in the Russian Economy: Stagnation before Crisis?]. Foresight-Russia, vol. 3, no 2, pp. 28-46.

Gokhberg L., Kuznetsova T. (2011) Strategiya-2020: novye kontury innovatsionnoi politiki [Strategy 2020: New Outlines of Innovation Policy]. ForesightRussia, vol. 5, no 4, pp. 40-46.

Gokhberg L., Kuznetsova T., Korolev V. (2011) Mezhdunarodnaya kooperatsiya kak imperativ sovremennoi innovatsionnoi politiki [International Co-operation as Imperative for the State-of-Art Innovation Policy]. Sodruzhestvo nezavisimykh gosudarstv: prostranstvo innovatsii [Community of Independent States: Space for Innovation], Moscow: Center for Strategic Partnership, pp. 41-49.

Gracheva G., Kuznetsova T., Roud V., Suslov A. (2012) Innovatsionnoe povedenie rossiiskikh predpriyatii [Innovative Behaviour of Russian Enterprises] (ed. L. Gokhberg), Moscow: HSE

Kondratyuk P. (2012) Pravovye osnovy i praktika primeneniya strakhovaniya professional'noi otvetstvennosti [Legal Frameworks and Practice of Insuring Professional Responsibility]. Finansovaya gazeta, no 3, p. 11.

Kuznetsova T. (2007) Perekhod na novye organizatsionno-pravovye formy: vyzovy dlya gosudarstvennykh nauchnykh uchrezhdenii [Passing to New Organizational-Legal Forms: Challenges for Public Research Institutes]. Paper presented at the VIII HSE International Conference «Modernisation of economy and public development», 3-5 April 2007, Moscow.

Kuznetsova T. (2011) Institutsional'nye reformy $v$ sektore issledovanii i razrabotok $v$ Rossii: snova $v$ nachale puti? [Institutional Reforms in the Russian R\&D Sector: Again at the Outset?]. XI Mezhdunarodnaya nauchnaya konferentsiya po problemam razvitiva ekonomiki i obshchestva [XI International Academic Conference on Economic and Social Development] (ed. E. Yasin), vol. 3, Moscow: HSE, pp. 575-584.

Mitin Y. (2010) Vybor strategii razvitiya dlya malykh innovatsionnykh kompanii [Choosing Development Strategy for the Small Innovation Companies]. Kreativnaya ekonomika, no 7 (43), pp. 57-61.

Nesterenko Y. (2006) Malyi innovatsionnyi biznes: novye podkhody k effektivnomu razvitiyu [Small Innovation Enterprises: New Approaches to Effective Development], Moscow: MPA-Press.

OECD (2006a) Enhancing the Role of SMEs in Global Value Chains: Conceptual Issues Draft Report, Paris: OECD.

OECD (2006b) The Athens Action Plan for Removing Barriers to SME Access to International Markets, Paris: OECD.

OECD (2007) Enhancing the Role of SMEs in Global Value Chains, Tokyo: OECD.

OECD (2008) Open Innovation in Global Networks, Paris: OECD.

OECD (2010a) The OECD Innovation Strategy. Getting A Head Start on Tomorrow, Paris: OECD.

OECD (2010b) SMEs, Entrepreneurship and Innovation, Paris: OECD.

OECD (2011a) OECD Reviews of Innovation Policy. Russian Federation, Paris: OECD.

OECD (2011b) OECD Economic Review of the Russian Federation, Paris: OECD.

OECD (2012) Financing SMEs and Entrepreneurs 2012: An OECD Scoreboard, Paris: OECD

Powell W.W., Grodal S. (2005) Networks of Innovators. The Oxford Handbook on Innovation (eds. J. Fagerberg, D. Mowery, R. Nelson), Oxford University Press, pp. 57-85.

Siegel D., Wessner C., Binks M., Lockett A. (2003) Policies Promoting Innovation in Small Firms: Evidence from the US and UK. Small Business Economics, vol. 25, pp. 675-705.

Taker R. (2006) Innovatsii kak formula rosta: Novoe budushchee vedushchikh kompanii [Innovation as Recipe for Growth: New Future for Leading Companies], Moscow: Olimp-Biznes.

World Bank (2010) Innovation Policy: A Guide for Developing Countries. Part II: Policy Functions, World Bank, pp. 71-105.

Xue L. (2012) The Evolution of Chinas Innovation System - Domestic Reform and Global Integration, Tsinghua University. 


\title{
Лучшие практики оценки научно-технологического Форсайта: базовые элементы и ключевые критерии'
}

\author{
Е.А. Макарова* , А.В. Соколова* *
}

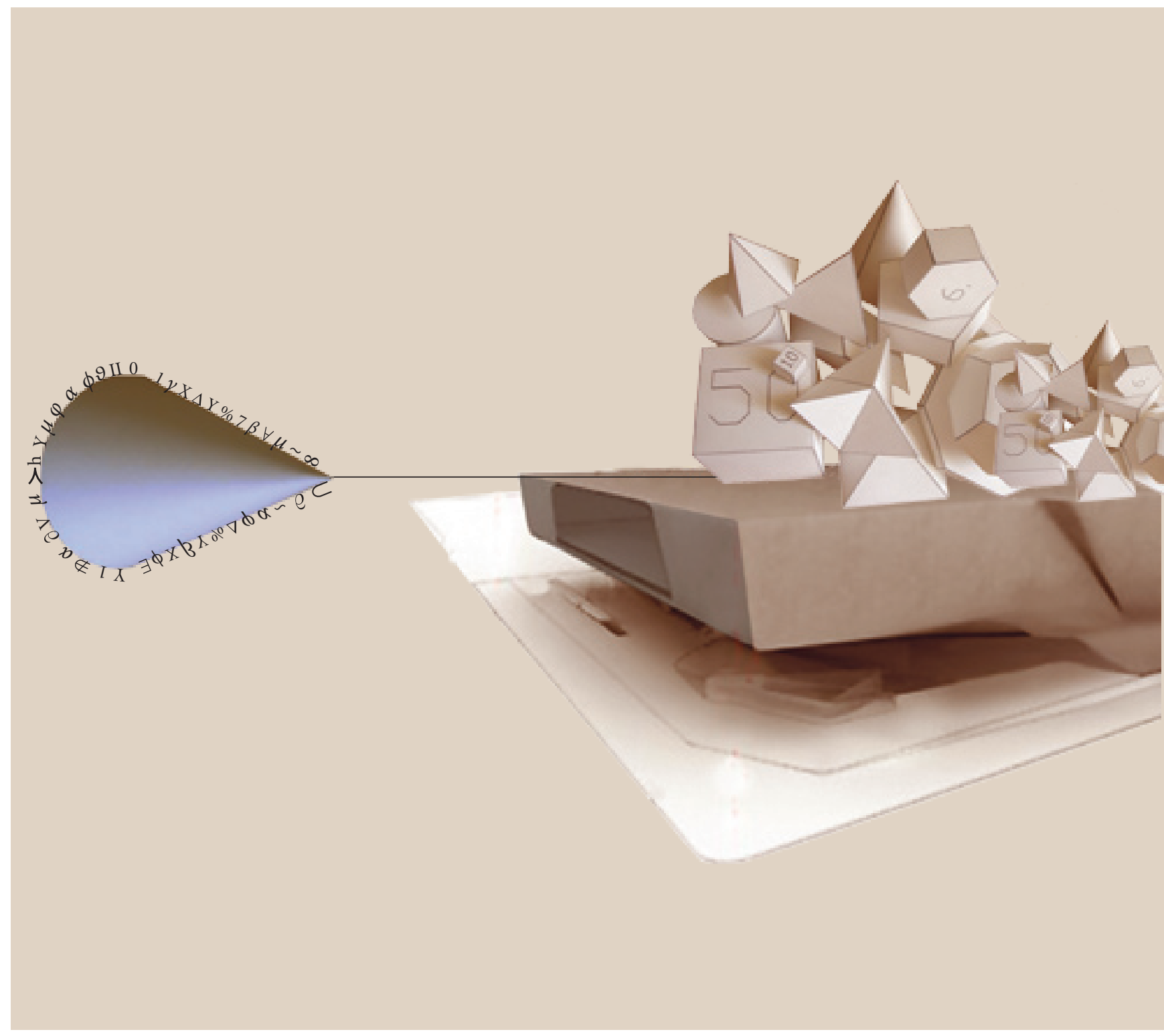

По мере усиления влияния Форсайт-исследований на формирование стратегий развития ужесточаются требования к качеству и обоснованности их результатов. Экспертиза Форсайт-проектов позволяет оценить эффективность мероприятий, принять решение о целесообразности их продолжения или мерах совершенствования.

В статье анализируются теория и лучшие практики оценки Форсайт-проектов, предпринята попытка систематизировать ее базовые элементы, критерии и методы. Предложена основа для разработки единой методологии оценки национальных Форсайт-программ.
* Макарова Екатерина Александровна - стажерисследователь, Лаборатория исследований науки и технологий. E-mail: kmakarova@hse.ru

** Соколова Анна Владимировна - старший научный сотрудник, Лаборатория исследований науки и технологий. E-mail: avsokolova@hse.ru

Институт статистических исследований и экономики знаний НИУ ВШЭ

Адрес: Национальный исследовательский университет

«Высшая школа экономики», 101000, Москва, Мясницкая ул., 20

\section{Ключевые слова}

Форсайт; оценка; управление проектами; лучшие практики. 
$\Phi$ орсайт как один из наиболее эффективных инструментов исследования будущего применяется в широком спектре областей: от научнотехнологического прогнозирования до формирования стратегий развития отдельных компаний, отраслей и стран. С каждым годом расширяется круг государств, реализующих Форсайт-проекты, растет число самих проектов: с 2005 по 2009 гг. оно удвоилось [Popper, 2009].

По мере усиления влияния Форсайт-исследований повышаются требования к качеству и обоснованности их результатов. Следовательно, большое значение приобретают своевременное выявление и устранение возможных организационных недостатков, которые могут быть обеспечены только в ходе комплексной оценки проектов. Экспертиза Форсайта необходима для анализа эффективности реализованных мероприятий, полученных результатов и путей совершенствования исследований [Georghiou, 2003].

Первые инициативы по оценке национальных Форсайт-программ были предприняты в конце 1990-х гг. По данной теме появились многочисленные научные публикации. Основное внимание в них уделялось изучению факторов, определяющих успех Форсайта и его влияние, поиску оптимальных критериев и методов, а также разработке соответствующих алгоритмов оценки [Майсснер, Сервантес, 2010; Meissner, 2012; Destatte, 2007; Calof, Smith, 2008; Alsan, Öner, 2004; Li et al., 2009, и др.].

В настоящее время в ряде стран ведутся крупномасштабные специализированные проекты по оценке национальных Форсайтов, на базе которых определяется дальнейший вектор развития исследований будущего, анализируются их отдельные элементы с целью совершенствования методологии. Ключевые инициативы представлены на рис. 1 в соответствии с фокусом (процесс реализации Форсайта, итоги, оказанное влияние) и сроком реализации.

Как показывает международная практика, в большинстве случаев временной интервал между реализацией исследования (или его этапа) и оценкой не превышает одного года, более того, подобные мероприятия зачастую начинаются еще в ходе проекта. Это связано, прежде всего, с тем, что заключения экспертизы непосредственно влияют на принятие решения о проведении следующего этапа (как, например, в Германии, Швеции и Великобритании) или инициировании нового Форсайта (Венгрия). В то же время в Японии между самими Форсайт-программами и их оценкой прошло более двадцати лет. Такой временной промежуток позволил охарактеризовать точность долгосрочных прогнозов.

Многообразие подобных кейсов свидетельствует о высокой заинтересованности стейкхолдеров различного уровня в оценке Форсайта. Тем не менее общие принципы ее организации и проведения до сих пор не сформулированы, что сдерживает развитие данной деятельности и распространение успешного опыта.

Необходимо выделить ключевые элементы, по которым будет проводиться оценка, и определить для них базовые критерии. Предлагаемый нами перечень элементов составляют: цели, проектная команда,

\section{Рис. 1. Обзор наиболее значимых проектов по оценке национальных Форсайт-программ}

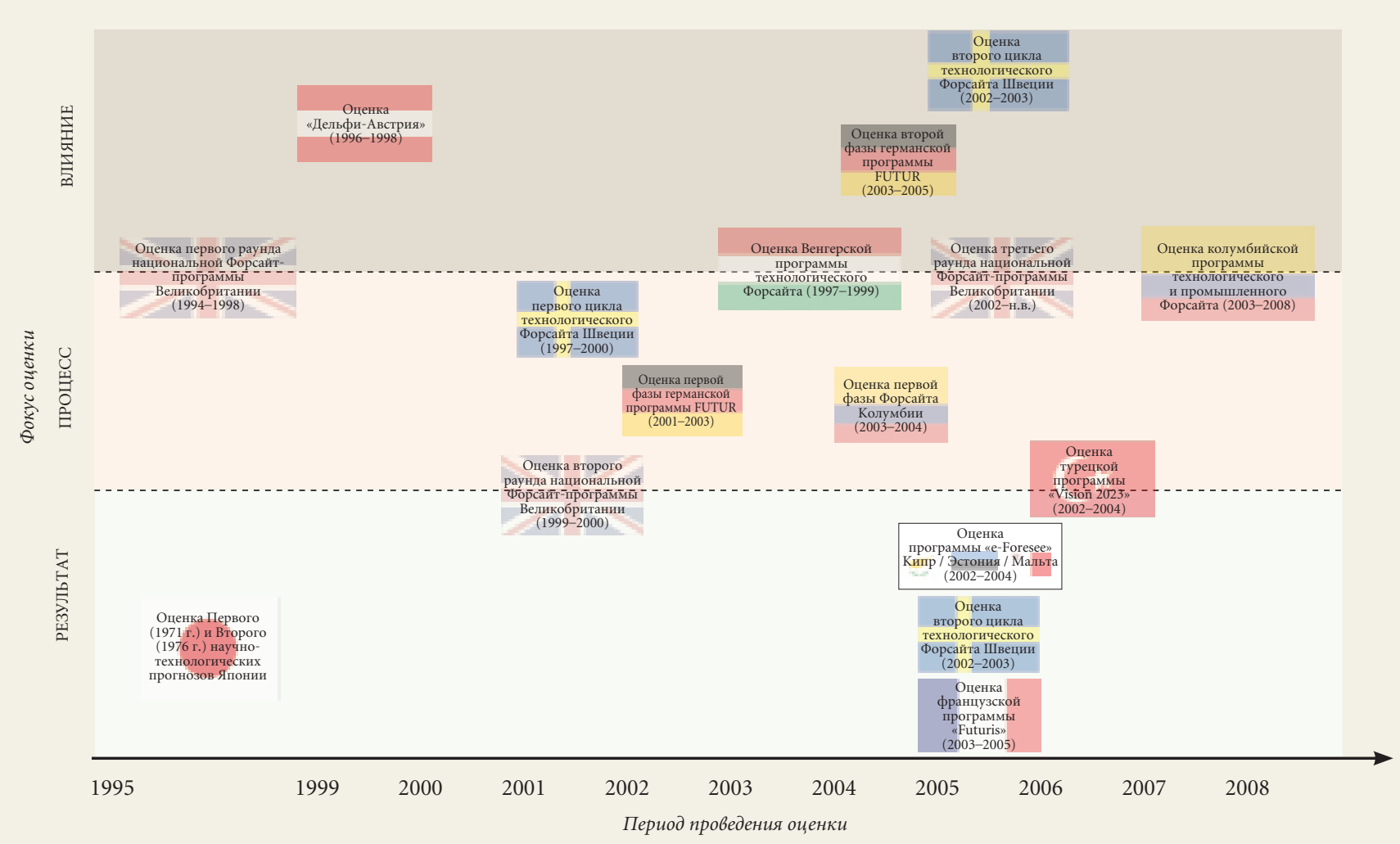

Источник: составлено авторами по материалам [Aichholzer, 2001; Björn, Lübeck, 2003; Cuhls, Georghiou, 2004; Daim et al., 2009; Dursun et al., 2011; FOR-LEARN online Foresight Guide; Georghiou et al., 2004a; Georghiou et al., 2006; Havas et al., 2007; Kuwahara et al., 2004; Wood, 2001]. 
заказчик(и), стейкхолдеры, методология, организация, ресурсы, результаты и эффекты Форсайт-исследования. Правомерность обозначенного состава элементов и соответствующих критериев основана на анализе опыта управления проектами и теории Форсайт-исследований, а также изучения практических примеров оценки национальных Форсайт-программ. Выбор кейсов базировался на следующих критериях и показателях:

- влияние на развитие Форсайт-исследований и научно-техническую политику в стране;

- временной фактор (осуществление в течение последнего десятилетия);

- масштабы оценки (анализ всей программы);

- наличие наиболее значимых результатов ${ }^{2}$ с точки зрения задач и объектов оценки, использованных методов и полученных выводов.

Кроме того, мы стремились представить проекты, различающиеся по социально-экономическим характеристикам страны проведения (если Германия и Великобритания имеют схожие черты, то экономические уклады Турции, Венгрии и Колумбии существенно отличаются) и по типу оценки (текущая для Форсайт-программы Великобритании, итоговая для программ Турции, Венгрии и Колумбии, промежуточная для германской программы FUTUR).

Для изучения отобранных проектов разработана стандартная схема, включающая определение задач, объекта, методов и итогов оценки, что позволило выявить наиболее общие элементы различных подходов к оцениванию Форсайт-исследований.

\section{Базовые концепции оценки Форсайт-исследований}

\section{Опыт общей теории оценки и управления проектами}

Ряд базовых подходов к экспертизе Форсайт-проектов заимствован из теоретических и практических концепций общей теории оценки. Это относится, например, к типам оценивания, которое может быть общим (рассматриваются весь набор примененных инструментов, целевые группы, ожидаемые эффекты); тематическим (фокус на отдельных элементах); предварительным (осуществляется до реализации проекта) и т. д. [European Commission, 1999]. Среди подходов к проведению экспертизы выделяют: ориентированность на задачи [Tyler, 1942], конструктивность - поиск консенсуса между всеми заинтересованными сторонами [Guba, Lincoln, 1989] и партисипативность, предполагающую вовлечение и совместную работу максимального числа стейкхолдеров [Owen, Lambert, 1998].

Существенный опыт проведения оценочных мероприятий накоплен в рамках теории и практики управления проектами. Под проектом в данном случае понимается совокупность ограниченных по времени взаимосвязанных видов деятельности, направленных на достижение специфической цели - создание уникального продукта или услуги [PMI, 1996; Phillips et al., 2002]. Указанные характеристики - временные ограничения, «специфичность» цели и «уникальность» продукта (рекомендаций, дорожных карт, перечней критических технологий) - присущи Форсайтисследованиям [Popper et al., 2010]. Поэтому, при определенной адаптации, опыт управления проектами может быть использован в их оценке.

Для оценки эффективности проектов, прежде всего их потенциальной прибыльности, применяется широкий арсенал методов [Remer et al., 1993; Remer, Nieto, 1995; Mishra, 2009; Phillips et al., 2002; Godinho et al., 2004, и др.], значительная часть которых обосновывает целесообразность проекта с финансовой точки зрения. Комплексность анализа Форсайт-проекта обеспечивается за счет включения, помимо экономической составляющей, таких элементов, как цели, стейкхолдеры, влияние и эффект.

Так, для оценки целей применяются критерии системы SMART (конкретность (Specific); измеримость (Measurable); достижимость (Achievable); правомерность (Relevant); контролируемость по времени (Timed)) и правило ABCD. Согласно последнему, в задачах должна отражаться информация о целевой аудитории (Audience), ее ожидаемом поведении (Behaviour), условиях (Conditions) и критериях оценки степени реализации (Degree) [Phillips et al., 2002; HM Treasury, 2003; Ricker et al., 1998]. При характеристике других элементов используются опросы, анализ документов, презентации, работа фокус-групп, статистический и мультикритериальный анализ, портфолио-методы [Zarinpoush, 2006; Westat, 2002; Eilat et al., 2008; Ricker et al., 1998; Bohanec et al., 1995; CROWN, 2009, и др.].

Разнообразие применяемых критериев и методов обусловливает широкий спектр подходов к организации оценочных процедур. Число обязательных стадий и их содержание значительно варьируются от проекта к проекту [HM Treasury, 2003; Westat, 2002; Ricker et al., 1998, и др.]. В ряде случаев применяется иерархия Беннета (Bennett's Hierarchy), включающая: ресурсы; виды деятельности; вовлеченность участников; обратную связь; изменения в системе знаний; отношения; умения и предпочтения, результаты [Bennett, 1975]. Специалисты Японского агентства по международному сотрудничеству (Japan International Cooperation Agency, JICA) предложили алгоритм из трех этапов: оценка эффективности проекта; анализ экспертных мнений; извлечение уроков и рекомендации для следующих стадий проекта или новых инициатив [JICA, 2004]. Наиболее общая последовательность действий по экспертизе проектов охватывает подготовительные работы, моделирование, сбор и анализ данных, экономическую оценку, распространение результатов.

Ниже мы определим ключевые элементы системы оценки Форсайт-исследований, а также попытаемся выявить возможные направления ее совершенствования на основе опыта управления проектами.

\footnotetext{
Результаты оценки национальных Форсайт-программ, как правило, не публикуются в открытом доступе. Так, лишь по нескольким из представленных на рис. 1 проектам доступны полные отчеты, отражающие информацию о структуре процесса, применявшихся подходах и методах, полученных результатах и разработанных рекомендациях; в остальных случаях сведения крайне ограничены. Доклады по оценке программ FUTUR и «Vision 2023» не были опубликованы, однако рекомендациях; в остальных случаях сведения крайне ограничены. Доклады по оценке программ FUTUR и
минимально необходимая информация представлена в ряде статей [Cuhls, Georghiou, 2004; Dursun et al., 2011, и др.].
} 


\section{Теоретические аспекты оценки}

\section{Форсайт-исследований}

Теоретическое оценивание Форсайт-программ ведется по трем направлениям: анализ факторов, способствующих успеху Форсайта, его эффектов и выбор опти мальных элементов экспертизы (методы, критерии, алгоритм и т. д.).

Программы могут характеризоваться как результативные, при условии наличия возможности эффективно извлекать знания о будущем и творческого подхода к разработке стратегий [Bezold, 2010]. К числу других критериев успешности относятся обязательная экспертиза темы, методологии и процесса [Habegger, 2010]; точная идентификация заказчика; связь с текущей политической повесткой; интенсивное взаимодействие представителей частного и государственного секторов; наличие четко определенной коммуникационной стратегии; глубокое вовлечение стейкхолдеров и др. [Calof, Smith, 2008].

В рамках различных подходов к интерпретации успешности Форсайта выявлен ряд стимулирующих факторов:

- наличие плана реализации исследования;

- достаточный уровень авторитета членов команды;

- открытость и прозрачность процесса;

- привлечение заинтересованных лиц из научного сообщества, бизнеса, государственного управления и общественных организаций [Майсснер, Сервантес, 2010].

Анализ представленных подходов позволяет выявить основные требования к эффективной реализации проекта: привлечение стейкхолдеров из разных сфер и обеспечение активного диалога между ними, связь с текущей стратегией развития страны, региона или отрасли, творческий подход, учет опыта предшествующих проектов.

Влияние Форсайт-исследований на экономику и общество выступает одновременно и ключевым показателем оценки, и одним из важнейших побудительных мотивов к их осуществлению. Его объектом могут быть: научно-техническая и инновационная политика, национальная инновационная система, конкурентоспособность страны, бизнес-среда и др. [Popper et al., 2010; Havas et al., 2010; Rollwagen et al., 2008; Meissner, Cervantes, 2008].

При анализе эффектов рекомендуется совместно рассматривать внутренние (относящиеся к участникам, процессу, целям, затраченным ресурсам и выходным результатам) и внешние факторы с учетом воздействия широкого окружения (институциональная среда, социокультурный аспект, уровень развития «обще ства знания», факторы управления и политической культуры) [Amanatidou, Guy, 2008]. Кроме того, может изучаться вклад Форсайт-программ в формирование «общества знания» [Rollwagen et al., 2008].

Наряду с оценкой успешности и влиятельности Форсайт-программ исследователи уделяют серьезное внимание вопросам выбора критериев оценивания. В качестве базовых фигурируют: целесообразность, эффективность, результативность, правомерность
[Georghiou, Keenan, 2006; Meissner, Cervantes, 2008; Popper et al., 2010; Destatte, 2007]. Критерий «изменение моделей поведения» (behavioural additionality) активно применяется при оценке влияния и представляет собой различие в поведении субъектов (компаний, правительств, стран и др.), проявившееся в итоге осуществления Форсайта [Georghiou et al., 2004b]. Более частные критерии, предназначенные для характеристики отдельных элементов исследования, как правило, разрабатываются в рамках практических оценочных процедур.

\section{Практический опыт оценки Форсайт-исследований}

\section{Национальная программа технологического Форсайта Венгрии}

Среди стран Центральной и Восточной Европы национальный Форсайт первой инициировала Венгрия в 1997 г. с целью идентификации долгосрочных исследовательских задач и приоритетов, способствующих формированию активной «догоняющей» стратегии развития страны [Kováts, 2000; Rader, 2003]. Тематический охват исследования включал человеческие ресурсы, здравоохранение, информационные технологии, промышленность и бизнес, энергетику, транспорт, сельскохозяйственное производство и защиту окружающей среды. Ключевыми инструментами служили разработка макросценариев, Дельфи и экспертные панели.

Участники проекта пришли к заключению, что устранению отставания Венгрии от развитых стран должна способствовать концентрация на таких направлениях, как образование, здравоохранение, культура населения и экология. Кроме того, подчеркивалась не обходимость создания эффективной национальной инновационной системы [Kováts, 2000].

Экспертиза Форсайта проводилась в 2003-2004 гг. международной экспертной группой, сформированной на базе Центра исследований научно-технической политики Университета Манчестера (PREST) ${ }^{3}$. Были проанализированы рациональность и важность первоначальных целей программы, эффективность организационной структуры и управления. Рассматривались также обоснованность вложенных затрат, барьеры для реализации разработанных по итогам Форсайта рекомендаций и оказанное им влияние [Georghiou, Keenan, 2006].

Главным источником данных для оценки служило анкетирование. Опросный лист состоял из нескольких тематических блоков, посвященных целям, методологии, организации, достигнутым эффектам, влиянию и направлениям развития Форсайта в стране. С целью уточнения и расширения полученных данных дополнительно проводились интервью и анализ отчетной документации. Структура оценки Форсайт-программы Венгрии представлена на рис. 2.

Оценка отдельных направлений (цели, методы, эффекты и др.) осуществлялась по различным шкалам. Так, целям и результатам в зависимости от степени важности присваивалось от одного до пяти баллов. При изучении самого процесса Форсайта респонденты руководствовались градацией «хорошо - 


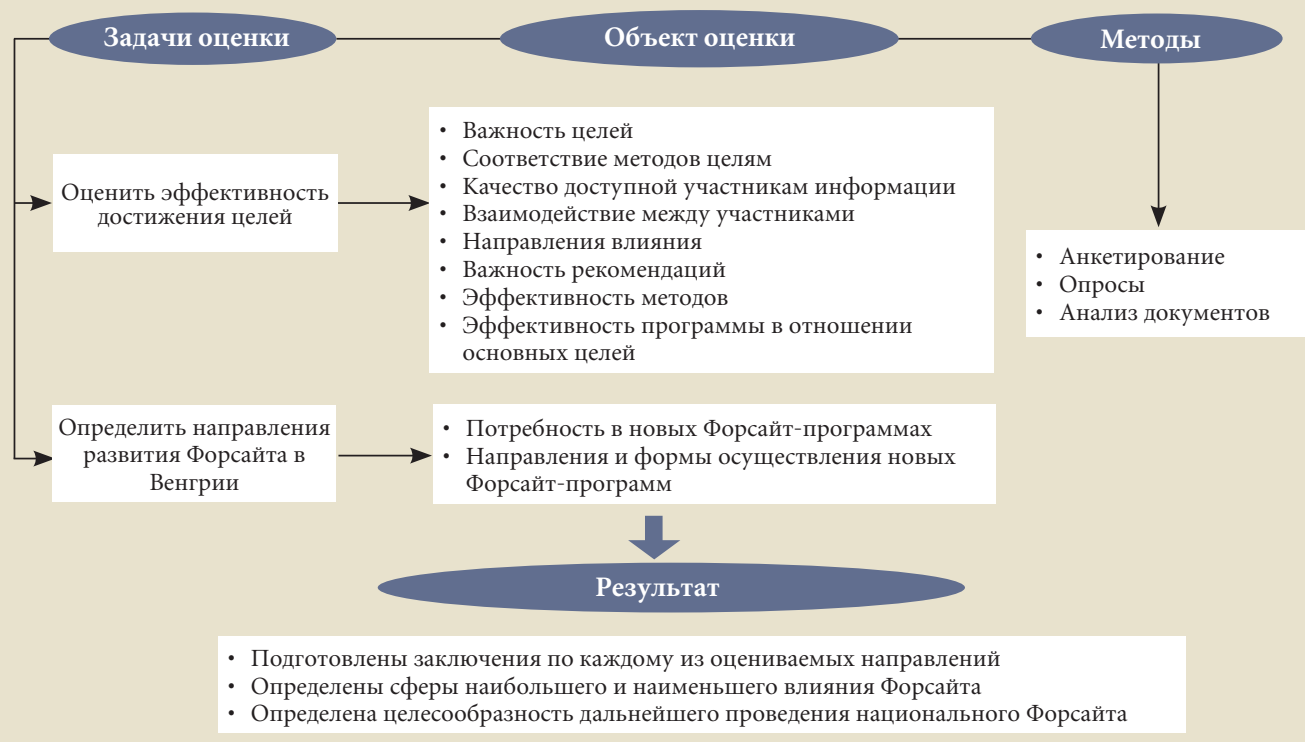

Источник: составлено авторами на основе [Georghiou et al., 2004a; Georghiou, Keenan, 2006].

удовлетворительно - плохо» [Georghiou et al., 2004a]. Кроме того, методы ранжировались по степени их полезности, а разработанные рекомендации - по величине эффективности.

Были определены сферы наибольшего влияния Форсайт-программы, в том числе выявление долгосрочных приоритетов и распространение междисциплинарного подхода. Значительным оказалось также воздействие Форсайта на формирование государственной политики (в области транспорта, здравоохранения и др.), однако оно нашло свое воплощение в «достаточно медленных и нелинейных процессах» [Georghiou, Keenan, 2006]. Наименьшее влияние, по мнению экспертов, программа оказала на тематику научных исследований в производственном и государственном секторах.

В блоке анкеты, посвященном определению будущих направлений развития Форсайта, содержались вопросы о необходимости новых проектов и форме их осуществления [Georghiou et al., 2004a].

Итоговый вывод заключался в том, что на текущий момент потребность в осуществлении столь же масштабной Форсайт-программы в Венгрии отсутствует, однако спустя десятилетие аналогичное исследование целесообразно повторить.

Проведение оценки способствовало определению вектора развития Форсайт-исследований и позволило выявить слабые места, которые могут быть учтены при реализации последующих программ. Однако ее характер признан достаточно субъективным, главным образом из-за отсутствия четких количественных и качественных критериев.

\section{Национальная Форсайт-программа Великобритании}

В 1993 г. Министерство науки Великобритании опубликовало доклад «Реализуя наш потенциал» («Realising our Potential»), обозначивший необходимость проведения в стране национального Форсайта [Wood, 2001]. Год спустя стартовал первый раунд национальной Форсайтпрограммы, нацеленный на определение будущих возможностей и вызовов в научно-технологической сфере и обеспечение эффективного взаимодействия между представителями научной среды, промышленности и государственного управления [Miles, 2003].

Программа проводилась в три раунда. Структуру первого составили отраслевые панели (в сфере энергетики, транспорта, финансовых услуг и др.), которые на втором этапе были дополнены тематическими панелями («Стареющее население», «Предупреждение преступности», «Промышленность в 2020 году») и сопутствующими программами, нацеленными на анализ отдельных тем. В третьем раунде на смену панельной структуре пришел проектный принцип. Ряд проектов уже завершились, некоторые из них продолжаются в настоящее время ${ }^{4}$. В рамках британского Форсайта проводились опросы Дельфи, разрабатывались сценарии и идентифицировались ключевые тренды.

В ходе первого раунда были определены приоритетные направления науки и технологий, подготовлены рекомендации по их развитию [Miles, 2003]. Анализ второго цикла выявил ряд недостатков в организации программы, в связи с чем было решено осуществить ее комплексную реструктуризацию, переведя на проектную основу. Важнейшими итогами третьего раунда стали идентификация вызовов и возможностей, возникающих в рамках новых направлений науки и технологий, и разработка рекомендаций для решения актуальных социальных проблем [Georghiou et al., 2006].

Оценка третьего раунда программы Великобритании проводилась в 2005 г. экспертами PREST. Объектами экспертизы являлись организация Форсайта и его 
эффекты, а базовым методом стали интервью. Помимо этого программа была проанализирована в контексте мирового опыта организации исследований будущего с точки зрения целей, ресурсов, процесса, продуктов и эффектов [Georghiou et al., 2006]. Для достижения четкого понимания взаимосвязи между целями, проводимыми мероприятиями и итогами проекта эксперты разработали логическую схему его реализации [ там же]. Это позволило рассмотреть иерархию целей, действий и эффектов и, таким образом, определить ожидаемые направления влияния (рис. 3). Кроме того, подобная схема упрощает проверку логики построения программы и формирует каркас для ее оценки.

Достигнутые результаты разделялись на кратко-, средне- и долгосрочные. К первым были отнесены выявление ключевых областей, формирование новых команд экспертов и стейкхолдеров; в качестве среднесрочных рассматривались определение различных вариантов будущего, разработка рекомендаций и выбор направлений развития экспертных сетей; долгосрочными считались эффекты для направлений исследований и разработок (ИиР) в государственном и частном секторе, научно-технологической политики и становления Форсайт-культуры.

Структура оценки третьего раунда Форсайта Великобритании приведена на рис. 4.

Эксперты пришли к выводу, что в целом Форсайтпрограмма реализуется успешно, однако ряд проектов характеризуется дефицитом ресурсов и низкой вовлеченностью общественности в их реализацию. Среди рекомендаций отмечалась также желательность расширения числа рассматриваемых проектов ${ }^{5}$. Кроме того, в связи с возрастающими рисками изменений в структуре управления целесообразно уделять большее внимание мотивации проектных команд.

\section{Форсайт-программа Германии FUTUR}

Программа FUTUR была инициирована Министерством образования и науки Германии (Bundesministerium für Bildung und Forschung, ВMBF) с целью определения приоритетных областей ИиР, а также формирования новых междисциплинарных тематических направлений [Cuhls, 2003; Giesecke, 2008].

Программа состояла из трех раундов. В рамках первого выявлялись и анализировались базовые тенденции, разрабатывались и реализовывались сценарии. Далее были внесены некоторые процедурные изменения, однако общая последовательность процесса сохранилась.

Значительную роль в осуществлении программы FUTUR сыграли семинары и открытые конференции, на которых обсуждались перспективы развития различных областей науки и сфержизни (напериоддо 2020 г.).Затем в ходе работы фокус-групп были отобраны несколько направлений и предложены соответствующие сценарии. Веб-сайт www.futur.de транслировал информацию

\section{Рис. 3. Логическая схема реализации Форсайт-программы Великобритании}

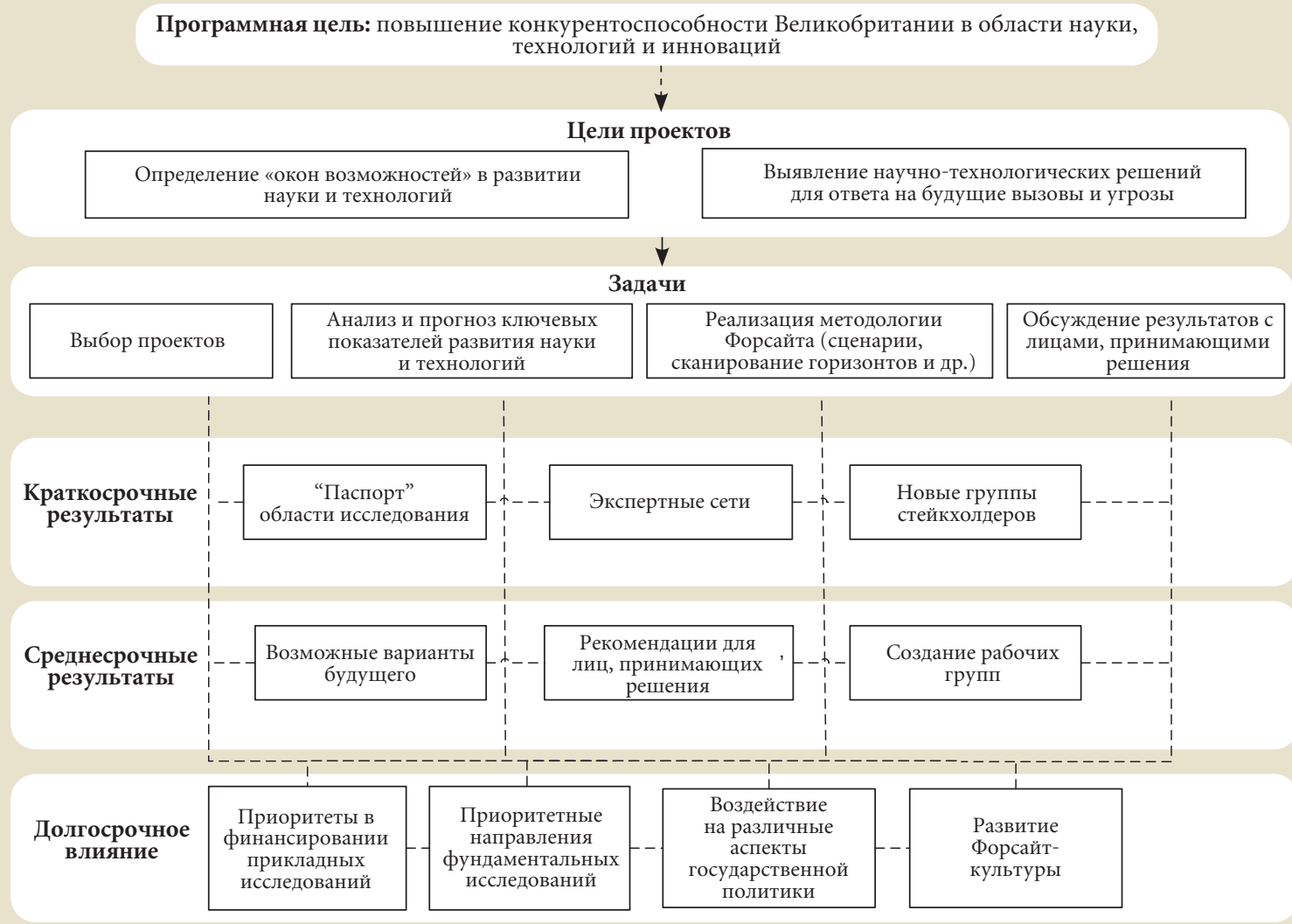

Источник: составлено авторами на основе [Georghiou et al., 2006].

В рамках британской Форсайт-программы были сформированы семь тематических проектов в следующих областях: наводнения и защита прибрежных территорий (подробнее см.: [Майлс, 2008]); когнитивные системы; кибер-доверие и предотвращение преступлений; применение электромагнитного спектра; наука о мозге, зависимость и наркотики; выявление инфекционных заболеваний; интеллектуальные системы. 


\section{Рис. 4. Структура оценки третьего раунда Форсайт-программы Великобритании}

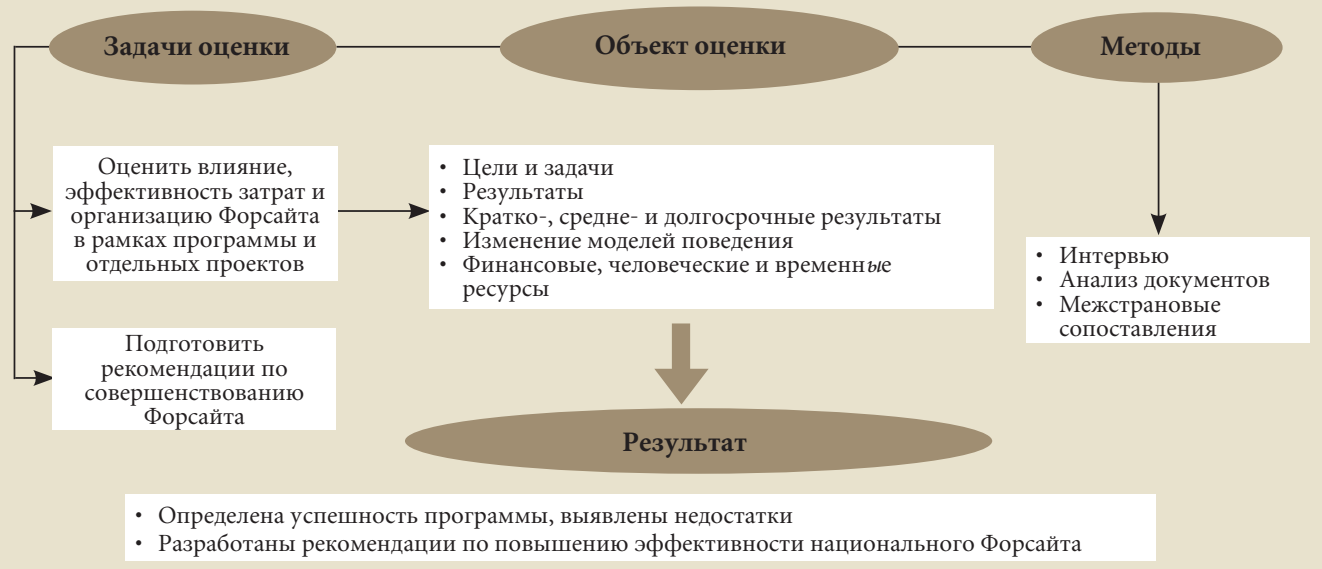

Источник: составлено авторами на основе [Georghiou et al., 2004a; Georghiou, Keenan, 2006].

о ходе программы и содержал виртуальное рабочее пространство для участников проекта.

Каждый раунд завершался разработкой стратегий развития ключевых областей. Были сформулированы характеристики выбранных тем, их значение для экономики и общества, цели, сценарии развития, приоритеты научной деятельности, уровень текущей проработанности [BMBF, 2002].

В 2002 г. по инициативе BMBF была осуществлена экспертиза первой фазы программы FUTUR (рис. 5). В ее ходе оценивались:

- рациональность и реализуемость целей;

- соответствие процесса в целом и его отдельных этапов достижению поставленных целей;

- способы оптимизации достижения целей;

- эффективность используемых инструментов с учетом целей программы [Cuhls, Georghiou, 2004].

Методология оценки была разработана специалистами Фраунгоферовского института системных и инновационных исследований (Fraunhofer Institute for Systems and Innovation Research, ISI). В отношении базовых объектов анализа (применявшихся инструментов, методов, форм организации) были сформулированы оценочные суждения в виде гипотез [Georghiou, Keenan, $2006]^{6}$, которые тестировались посредством четырехраундового опроса, охватившего участников, сотрудников BMBF, поддерживающих и координационных структур. Итоговые выводы были вынесены на обсуждение международной группы экспертов.

Эксперты пришли к выводу, что программа осуществляется успешно, однако процесс работы следует упростить, сделать его более открытым, что сократит затраты и сроки реализации. Рекомендации, подготовленные в ходе оценки, были учтены при разработке второго раунда.

Оценка программы FUTUR отличалась рядом специфических характеристик. Так, с методологической точки зрения представляет интерес использование гипотез в качестве элемента анализа. Вместе с тем, закрытый характер значительной части информации не позволяет сделать объективные выводы о методах проверки гипотез и структуре анкет.

Рис. 5. Структура оценки программы FUTUR (Германия)



Источник: составлено авторами на основе [Cuhls, Georghiou, 2004; Georghiou, Keenan, 2006].

${ }^{6}$ Например, в отношении методов организации предложена следующая гипотеза: «открытые мероприятия, такие как публичные конференции, являются действенным инструментом реализации Форсайта» [Cuhls, Georghiou, 2004]. 
Форсайт-программа Турции «Vision 2023: стратегии научно-технологического развития»

В начале 2000-х гг. власти Турции осознали неэффективность инициатив по поддержке исследований и разработок, реализованных в 1990-х гг., и, как следствие, необходимость выработки новой национальной научно-технологической политики на первые десятилетия наступившего века. В качестве фундаментальной задачи к 2023 г. (столетию основания Турецкой республики) ставилось создание инновационной экономики.

Программа «Vision 2023» была направлена на определение перспективных направлений науки и технологий в ближайшие двадцать лет и распространение этой информации среди заинтересованных кругов [Saritas et al., 2007]. В ходе программы анализировались различные варианты научно-технологического развития, выявлялись стратегически важные технологии и ключевые области ИиР.

Помимо Форсайта, инструментарий которого включал метод Дельфи, экспертные панели и определение приоритетных областей, в структуру программы входили три вспомогательных проекта по сбору и оценке данных в отношении технологических возможностей, трудовых ресурсов и инфраструктуры науки [Saritas et al., 2007]. Были сформированы перечни приоритетных областей научно-технологического развития и стратегических технологий ${ }^{8}$. Итоговые выводы и рекомендации легли в основу национальной научнотехнологической политики Турции, рассчитанной на период до 2023 г.
Экспертиза программы «Vision 2023» состояла из следующих стадий: определение и разработка базовых элементов оценки, собственно оценивание и подготовка отчета [Dursun et al., 2011]. Первая стадия заключалась в формулировании целей, моделировании процесса и выборе источников данных и инструментов для анализа. В ходе второй разрабатывались и распространялись анкеты, которые обрабатывались с помощью статистического инструментария, проводились дополнительные интервью, анализировалась документация. Третья стадия охватывала подготовку экспертного заключения и его презентацию.

Наибольшую важность с точки зрения обеспечения эффективности процесса представляла разработка модели, позволившая уточнить характер и степень вклада предлагаемых мероприятий в достижение поставленных целей. Модель оценки состояла из трех элементов: затраты (первоначальные), методы и результаты [Dursun et al., 2011]. Каждому элементу соответствовали определенные критерии оценки: достаточность (затраты); эффективность (методы); степень достижения (результаты).

Основными методами оценивания стали интервью (личные, телефонные либо с использованием электронной почты), анкетирование и анализ документов (рис. 6). Анкета имела три тематических блока: управление проектом, методология и результаты.

Кроме этого, при оценке итогов программы «Vision 2023» рассматривались отчеты экспертных панелей, посвященные отраслевым технологическим трендам,

Рис. 6. Структура оценки программы «Vision 2023» (Турция)

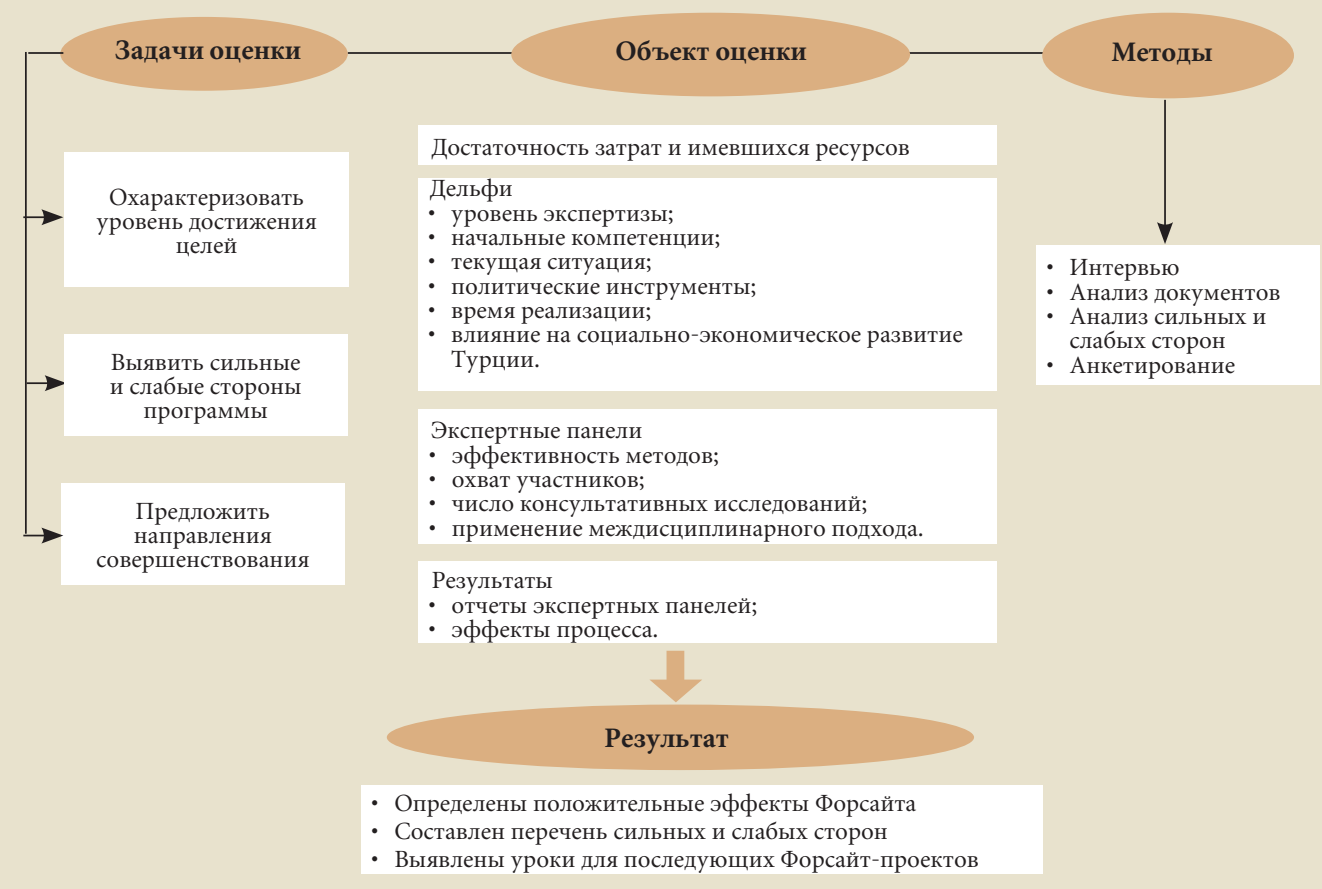

Источник: составлено авторами на основе [Dursun et al., 2011].

Информационно-коммуникационные технологии; образование и человеческие ресурсы; энергетика; природные ресурсы; здравоохранение и фармацевтика; оборонный, авиационный и космический сектора; обрабатывающее производство и материалы; транспорт; туризм; текстильная промышленность; химия; строительство и инфраструктура; сельское хозяйство и продовольствие; окружающая среда и устойчивое развитие.

8 Информационно-коммуникационные технологии; нанотехнологии; технологии материалов; производственные процессы и технологии; биотехнологии и генная инженерия; мехатроника; инструменты дизайна; технологии энергетики и окружающей среды. 
SWOT-анализу, технологическим стратегиям и приоритетным направлениям развития науки и технологий. Были отмечены положительные эффекты Форсайта: вовлечение широкого круга участников, координация будущих научных исследований, информирование общественности и др. Завершающий этап оценки состоял в выявлении сильных и слабых сторон программы, а также подготовке рекомендаций для ее дальнейшего совершенствования [Daim et al., 2009].

Проект оценки Форсайт-программы Турции явился единственным примером, когда стадия моделирования была включена в общий алгоритм в явном виде. Разработка модели позволила избежать возможных ошибок при планировании процесса оценивания, сделав его более структурированным и понятным.

\section{Программа технологического и промышленного Форсайта Колумбии}

Колумбийская программа технологического и промышленного Форсайта, стартовавшая в 2001 г., до настоящего момента является наиболее масштабной инициативой по исследованиям будущего в Латинской Америке. В качестве базовых целей были намечены определение стратегических направлений развития науки и технологий, стимулирование создания в стране экономики и общества знаний, повышение компетенций в области Форсайта и распространение соответствующей культуры [Medina, 2006].

В структуре первого цикла прогнозные исследования разделялись на отраслевые, территориальные и смешанные. В рамках второго основополагающим признаком классификации проектов являлась их методология (собственно Форсайт, сканирование горизонтов и др.) [Popper et al., 2010]. В общей сложности были осуществлены 32 специализированных проекта, с применением различных опросов, разработкой сценариев, проведением SWOT-анализа и организацией экспертных панелей. Особо примечательна реализация в режиме онлайн четырехраундового Дельфи-опроса [Popper et al., 2010].

Итогами первого этапа стали: определение стратегий развития ключевых областей науки и технологий, совершенствование компетенций и разработка мер по укреплению национальной инновационной системы. Вторая стадия в 2007-2008 гг. была подвергнута широкомасштабной оценке международной группой экспертов, сформированной на базе PREST. В рамках проекта анализировались влияние программы, эффективность затрат, методы организации Форсайта, а также готовились рекомендации для будущих проектов в стране.

Экспертиза проходила в четыре этапа [Popper et al., 2010]. На первом определялись цели, задачи и структура оценки; в ходе второго проводились интервью и анализ информации; в рамках третьего цикла осуществлялись межстрановые сопоставления, представлялись промежуточные результаты, обсуждавшиеся с расширенной международной группой экспертов. Одновременно был организован Интернет-опрос для определения текущего и ожидаемого влияния реализуемых в рамках Форсайт-программы проектов. Финальная стадия включала подготовку и согласование итогового отчета.

Оценка подразумевала широкий набор методов. Межстрановые сопоставления национальных программ базировались на десяти критериях 9 . Для характеристики ряда показателей в качестве ключевого метода использовались интервью. Значительное внимание уделялось изменениям в организационной структуре, имевшим место при переходе от первого цикла ко второму, и их влиянию на эффективность программы. С помощью Интернет-опросов изучались степень новизны и эффекты программы, результативность подходов и методов, достигнутый уровень компетенций и Форсайт-культуры (рис. 7).

Особый акцент ставился на обеспечении соответствия полученных результатов специфическим для колумбийской программы требованиям. Так, ряд разработанных критериев предназначались для определения влияния Форсайт-программы на национальную систему науки, технологий и инноваций, а также ее вклада в формирование «общества знаний» [Popper et al., 2010].

Предметом итоговых рекомендаций стало расширение применения Форсайта в научно-технической и инновационной сфере (консолидация исследовательской инфраструктуры; поддержка исследований в стратегических областях и др.). Выводы представлялись по трем тематическим направлениям: эффективность использования средств, цели программы и «прочие достижения». Отмечалась высокая эффективность финансирования Форсайт-программы. Выводы, касающиеся целей, свидетельствовали об «устойчивом прогрессе» в их реализации [Popper et al., 2010]. В качестве «прочих достижений» выделялись гибкость программы, ее адаптивность, эффективное взаимодействие между представителями государства, бизнеса и академического сообщества на национальном и международном уровнях.

Оценку колумбийского технологического и промышленного Форсайта можно охарактеризовать как масштабный и эффективно реализованный проект, который, наряду с формированием практических выводов и рекомендаций, способствовал консолидации имеющихся знаний и разработке новых методологических подходов. Особо следует отметить большое число проектов, охваченных экспертизой.

\section{Базовые элементы оценки национального Форсайта}

Сопоставление представленных выше проектов по экспертизе национальных Форсайт-инициатив позволяет заключить, что в большинстве случаев подобные оценки ориентированы на анализ реализации исследований будущего, достигнутых в них результатов и оказанного влияния. Не менее важной задачей являются обоснование направлений совершенствования Форсайта и подготовка рекомендаций в отношении будущих программ.

\footnotetext{
9 Кооперация, спонсирование, целевая аудитория, масштаб участия, длительность проекта, финансирование, территориальное распределение, временной горизонт, методы, результаты [Popper et al., 2010].
} 

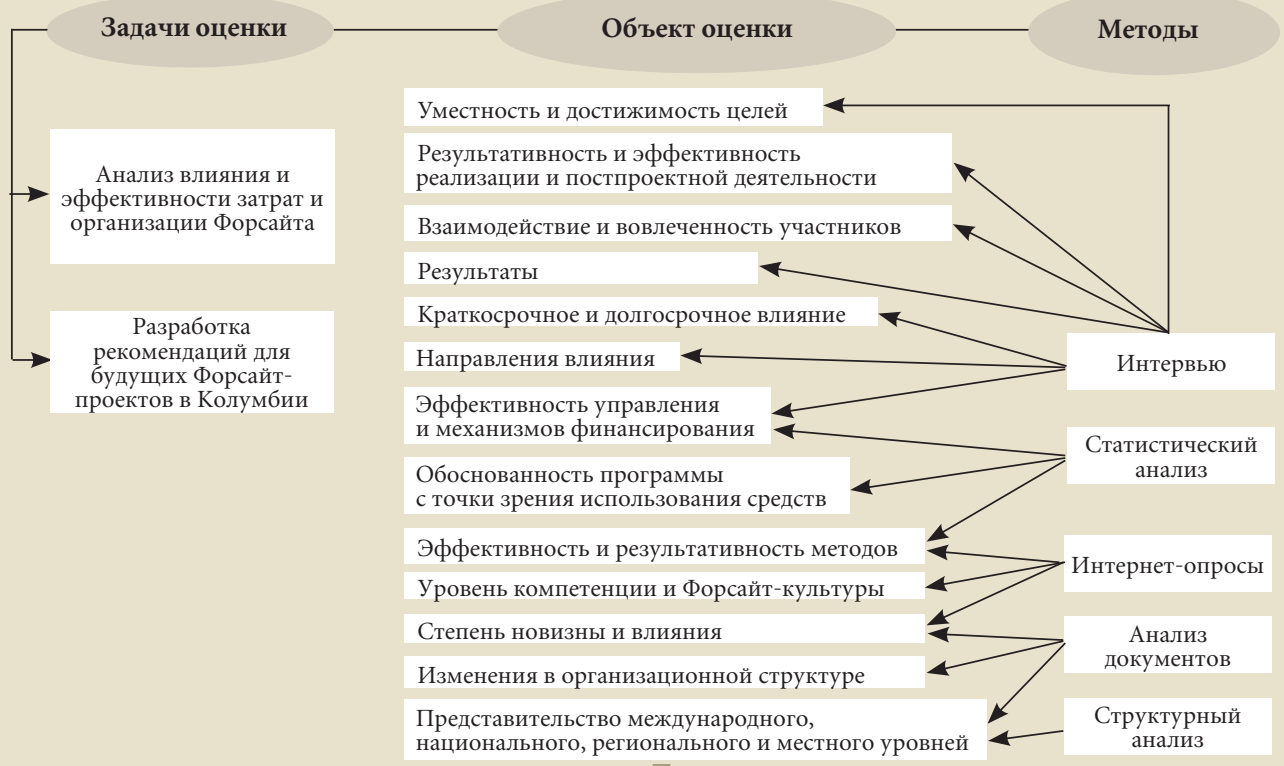

Результат

- Получены заключения в отношении целей программы, эффективности используемых методов и “прочих достижений”.

- Предложены рекомендации по более активному использованию Форсайта.

Источник: составлено авторами на основе [Popper et al., 2010].

Наиболее распространенным методом оценки выступают интервью: к ним прибегали эксперты в ходе всех рассмотренных выше проектов. Достаточно часто проводились анкетные опросы и применялись инструменты статистического анализа.

Итоги оценочных мероприятий обычно публикуются в виде отчетов, в которых обсуждаются достоинства и недостатки Форсайт-проектов, содержатся необходимые рекомендации. В некоторой степени типичными являются и слабые стороны оценочных проектов: отсутствие единых шкал для измерения определенных критериев, ограниченное применение количественных методов, информационная закрытость. Отмеченные обстоятельства усиливают субъективность итоговых оценок и формируют преграды для их использования заинтересованными лицами.

Фундаментальным вопросом при проведении любого оценивания является установление соответствующих критериев. Анализ практического опыта с учетом известных теоретических подходов позволяет сгруппировать показатели оценки Форсайт-исследований в соответствии с выделенными элементами (цели, заказчик, проектная команда, стейкхолдеры, методология, организация, ресурсы, результаты и влияние). Критерии для каждого из предложенных элементов, предлагаемые теорией и практикой оценки Форсайта и дополненные авторами на основе опыта реализации российских Форсайт-проектов, представлены на рис. 8.

Индикаторами при изучении целей выступают рациональность, достижимость, непротиворечивость и четкость формулировок. При оценке проектной команды рассматриваются такие параметры, как уровень квалификации и опыта ее членов с точки зрения соответствия решаемым задачам, а также степень независимости. Последнее требует проведения анонимных опросов команды.

Позиция заказчика (в частности, способность влиять на состояние национальной инновационной системы) может быть определена посредством анализа документов и интервью с исполнителями проекта. Степень его участия в Форсайт-процессе выявляется соответственно характеру взаимодействия с проектной командой. Блок, посвященный стейкхолдерам, содержит информацию о вовлеченности в программу представителей ключевых секторов и организаций разных уровней.

Одно из наиболее важных направлений оценки - методология. Адекватность выбранных методов с позиций достижения поставленных целей может быть определена посредством анализа вклада каждого метода в реализацию соответствующей цели (задачи) исследования. Здесь же рассматривается подход к определению методов: случайный выбор, избирательное применение некоторых инструментов, комплекс различных методов [Майсснер, Сервантес, 2010]. Для полноты данного блока предлагается анализировать наличие в методологии инструментов из всех вершин Форсайт-ромба [Popper, 2009] и эффективность их совместного использования.

Организация Форсайт-процесса оценивается в соответствии со стадиями: пред-Форсайт, привлечение участников, генерирование знаний, действие, получение обратной связи [Miles, 2002]. Для каждой из них определяется эффективность деятельности, выявляются управленческие и организационные ошибки. Кроме того, изучается качество планирования с помощью 


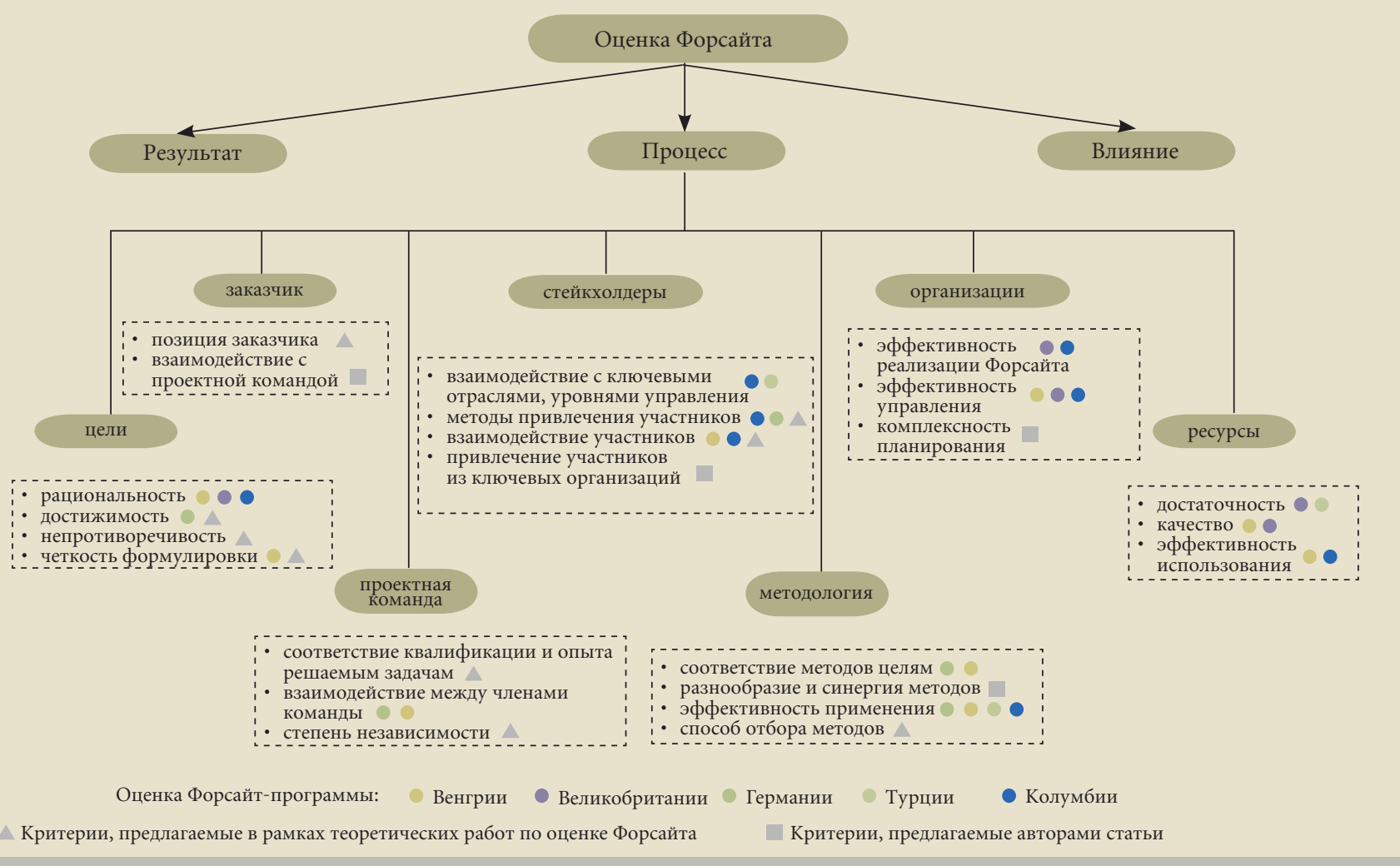

сопоставления ожидаемых и фактических итогов тех или иных мероприятий.

Рассмотренные выше элементы и критерии представляют основу методологии оценки национального Форсайта в части его реализации. Предлагаемые критерии могут использоваться для экспертизы Форсайтпроектов в различных вариантах и сочетаниях в зависимости от специфических целей. В дальнейшем предлагаемая методология будет дополнена детальными блоками по оценке результатов и эффектов, глубокий анализ которых остался за рамками нашего исследования.

\section{Заключение}

В ходе исследования были рассмотрены примеры оценки национальных Форсайт-программ в Венгрии, Великобритании, Германии, Турции и Колумбии. Наиболее масштабным и эффективным по глубине и детальности проработки явился колумбийский проект. Как показал анализ, главным фактором, мотивирующим к проведению оценки, является формирование обратной связи для национального Форсайта и определение направлений его дальнейшего развития. Так, в Венгрии пришли к выводу о целесообразности повторения через десять лет полномасштабного Форсайта. В ходе внутренней экспертизы второго раунда Форсайта Великобритании (отчет по которой не был опубликован) было принято решение о серьезной реструктуризации программы, и третий раунд был организован на проектной основе. При оценке последнего выявилась необходимость расширения программы (аналогичный вывод был сделан и в Турции). Таким образом, итогом любого оценочного проекта становились рекомендации по корректировке направлений развития национального Форсайта (в той или иной степени) и перечень извлеченных уроков для инициирования дальнейших исследований (например, упрощение процесса, активное привлечение бизнеса и общественных организаций и пр.).

Анализ практического опыта и теоретических разработок пока свидетельствует об отсутствии единых принципов проведения экспертизы. В рамках данного исследования были систематизированы и обобщены различные подходы к оценке национального Форсайта, выявлены ее важнейшие элементы и соответствующие критерии, что, по нашему мнению, будет способствовать стандартизации оценочных процедур.

Майлс Й. (2008) Разработка сценариев и дорожных карт для ключевых технологий: предупреждение наводнений и защита береговых территорий в Великобритании // Форсайт. Т. 2. № 4. С. 50-59.

Майсснер Д., Сервантес М. (2010) Успешный Форсайт: дизайн, подготовка, инструментарий // Форсайт. Т. 4 . № 1. С. 74-81.

Aichholzer G. (2001) Delphi Austria: An Example of Tailoring Foresight to the Needs of a Small Country. Vienna: ITA.

Alsan A., Öner M.A. (2004) Comparison of National Foresight Studies by Integrated Foresight Management Model // Futures. Vol. 36. № 8. P. 889-902. Amanatidou E., Guy K. (2008) Interpreting Foresight Process Impacts: Steps Towards the Development of a Framework Conceptualising the Dynamics of 'Foresight Systems' // Technological Forecasting and Social Change. Vol. 75. № 4. P. 539-557.

Bennett C. (1975) Up the Hierarchy // Journal of Extension. Vol. 13. № 2. P. 7-12.

Bezold C. (2010) Lessons from Using Scenarios for Strategic Foresight // Technological Forecasting and Social Change. Vol. 77. № 9. P. 1513-1518. Björn L., Lübeck L. (2003) Swedish Technology Foresight - A Successful Project With Many Lessons Learned. Paper presented at the Second International Conference on Technology Foresight, 27-28 February, Tokyo.

BMBF (2002) Futur Lead Visions Complete Document. Berlin: German Ministry for Education and Research. 
Bohanec M., Rajkovič V., Semolič B., Pogačnik A. (1995) Knowledge-Based Portfolio Analysis for Project Evaluation // Information \& Management. Vol. 28. № 5. P. 293-302.

Calof J., Smith J.E. (2008) Critical Success Factors for Government Led Foresight. Paper presented at the Third International Seville Seminar on Future Oriented Technology Analysis: Impacts and Implications for Policy and Decision-Making, Seville, October 16-17.

CROWN (2009) Multi-Criteria Analysis: A Manual. London: Department of Communities and Local Government. http://www.communities.gov. uk/documents/corporate/pdf/1132618.pdf (accessed 29 August 2012).

Cuhls K. (2003) From Forecasting to Foresight Processes - New Participative Foresight Activities in Germany // Journal of Forecasting. Vol. 22. P. 93-111.

Cuhls K., Georghiou L. (2004) Evaluating a Participative Foresight Process: "Futur — The German Research Dialogue" // Research Evaluation. Vol. 13. № 3. P. 143-153.

Daim T., Basoglu N., Dursun O., Saritas O., Pisek G. (2009) A Comprehensive Review of Turkish Technology Foresight Project // Foresight. Vol. 11. № 1. P. 21-42.

Destatte P. (2007) Evaluation of Foresight: How to Take Long-Term Impacts into Consideration? Paper presented at FOR-LEARN Mutual Learning Workshop-Evaluation of Foresight, 19 September, Brussels.

Dursun O., Türe T.E., Daim T.U. (2011) Post-Evaluation of Foresight Studies: Turkish Case // International Journal of Foresight and Innovation Policy. Vol. 7. № 4. P. 311-337.

Eilat H., Golany B., Shtub A. (2008) R\&D Project Evaluation: An Integrated DEA and Balanced Scorecard Approach // Omega International Journal of Management Science. Vol. 36. № 5. P. 895-912.

European Commission (1999) Evaluation of Socio-Economic Programmes. Glossary of 300 Concepts and Technical Terms. Luxembourg: "Means" Collection.

FOR-LEARN - On Line Foresight Guide. http://forlearn.jrc.ec.europa.eu/guide/7_cases/futur.htm (accessed 27 July 2012).

Georghiou L. (2003) Evaluating Foresight and Lessons for Its Future Impact. Paper presented at The Second International Conference on Technology Foresight, 27-28 February, Tokyo.

Georghiou L., Acheson H., Cassingena Harper J., Clar G., Klusacek K. (2004a) Evaluation of the Hungarian Technology Foresight Programme (TEP). Report of an International Panel. Manchester: PREST, University of Manchester.

Georghiou L., Clarysse B., Steurs G., Bilsen V., Larosse J. (2004b) Making the Difference - The Evaluation of Behavioural Additionality of R\&D Subsidies. Brussels: IWT Vlaanderen, IWT Studies 48.

Georghiou L., Keenan M. (2006) Evaluation of National Foresight Activities: Assessing Rationale, Process and Impact // Technology Forecasting and Social Change. Vol. 73. № 7. P. 761-777.

Georghiou L., Cameron H., Keenan M., Miles I., Saritas O. (2006) An Evaluation of the UK Foresight Programme: Final Report. Manchester: PREST, University of Manchester.

Giesecke S. (2008) Futur - The German Research Dialogue // Giesecke S., Crehan P., Elkins S. (eds.) The European Foresight Monitoring Network. Collection of EFMN Briefs. Part 1. Luxembourg: Office for Official Publications of the European Communities.

Godinho P.C., Afonso A.R., Costa J.P. (2004) On the Use of Multiple Financial Methods in the Evaluation and Selection of Investment Projects // Investigação Operacional. Vol. 24. № 1. P. 1-20.

Guba E., Lincoln Y. (1989) Fourth Generation Evaluation. London: Sage Publications.

Habegger B. (2010) Strategic Foresight in Public Policy: Reviewing the Experiences of the UK, Singapore, and the Netherlands // Futures. Vol. 42. № 1. P. 49-58.

Havas A., Schartinger D., Weber K.M. (2007) Experiences and Practices of Technology Foresight in the European Region. Paper presented at the UNIDO Technology Foresight Summit 2007, 27-29 September, Budapest.

Havas A., Schartinger D., Weber A. (2010) The Impact of Foresight on Innovation Policy-Making: Recent Experiences and Future Perspectives // Research Evaluation. Vol. 19. № 2. P. 91-104.

HM Treasury (2003) The Green Book: Appraisal and Evaluation in Central Government. London: TSO.

JICA (2004) JICA Guideline for Project Evaluation (September 2004). Japan International Cooperation Agency. P. 141-145. http://www.jica.go.jp/ english/operations/evaluation/tech_and_grant/guides/guideline.html (accessed 15 August 2012).

Kováts F. (2000) The Hungarian Technology Foresight Programme. Report by the Steering Group. Budapest.

Kuwahara T., Kameoka A., Yokoo Y. (2004) A challenge of integrating technology foresight and assessment in industrial strategy development and policymaking // Technological Forecasting and Social Change. Vol. 71. № 6. P. 579-598.

Li S.S., Kang M.H., Lee L.C. (2009) Developing the Evaluation Framework of Technology Foresight Program: Lessons Learned from European Countries. Paper presented at the Atlanta Conference on Science and Innovation Policy, Atlanta, October 2-3.

Medina J. (2006) Colombian Program on Technological and Industrial Foresight: Achievements and Perspectives. Bogotá: Colciencias.

Meissner D., Cervantes M. (2008) Results and Impact of National Foresight Studies. Paper presented at the Third International Seville Seminar on Future Oriented Technology Analysis: Impacts and Implications for Policy and Decision-Making, Seville, October 16-17.

Meissner D. (2012) Results and impact of national Foresight-studies // Futures (forthcoming).

Miles I. (2002) Appraisal of Alternative Methods and Procedures for Producing Regional Foresight. Report prepared by CRIC for the European Commission's DG Research funded STRATA - ETAN Expert Group Action. Manchester.

Miles I. (2003) Ten Years of Foresight in the UK. Paper presented at NISTEP Second International Conference on Technology Foresight, Tokyo, February 27-28.

Mishra S. (2009) Engineering Economics and Costing. New Delhi: PHI Learning Private Limited.

Owen J., Lambert F. (1998) Evaluation and the Information Needs of Organizational Leaders // American Journal of Evaluation. Vol. 19. № 3. P. 355-365.

Phillips J.J., Bothell T.W., Snead G.L. (2002) The Project Management Scorecard: Measuring the Success of Project Management Solutions. Woburn: Butterworth-Heinemann.

PMI (1996) A Guide to the Project Management Body of Knowledge. Newton Square, PA: Project Management Institute.

Popper R. (2009) Mapping Foresight: Revealing How Europe and Other World Regions Navigate into the Future, EFMN. Luxembourg: Publications Office of the European Union, European Commission.

Popper R., Georghiou L., Keenan M., Miles I. (2010) Evaluating Foresight: Fully-Fledged Evaluation of Colombian Technology Foresight Programme. Santiago de Cali: Universidad del Valle.

Rader M. (2003) Hungary - Hungarian Foresight Programme (TEP) 1997/99. FISTERA report WP 1 - Review and Analysis of National Foresight D1.1. HU - Case Study.

Remer D.S., Nieto A.P. (1995) A Compendium and Comparison of 25 Project Evaluation Techniques. Part 1: Net Present Value and Rate of Return Methods // International Journal of Production Economics. Vol. 42. № 1. P. 79-96.

Remer D.S., Nieto A.P. (1995) A Compendium and Comparison of 25 Project Evaluation Techniques. Part 2: Ratio, Payback and Accounting Methods // International Journal of Production Economics. Vol. 42. № 2. P. 101-129.

Remer D.S., Stokdyk S.B., Driel M.V. (1993) Survey of Project Evaluation Techniques Currently Used in Industry // International Journal of Production Economics. Vol. 32. № 1. P. 103-115.

Ricker K.T., Brown L.C., Leeds C.F., Leeds R.P., Bonar Bouton E.K., Volgstadt C.E. (1998) Water Quality Project Evaluation: A Handbook for Objectives-Based Evaluation of Water Quality Projects. http://ohioline.osu.edu/b868 (accessed 13 July 2012).

Rollwagen I., Hofmann J., Schneider S. (2008) Improving the Business Impact of Foresight // Analysis \& Strategic Management. Vol. 20. № 3. P. 337-349.

Saritas O. (2006) Systems Thinking for Foresight. PhD Thesis. The University of Manchester.

Saritas O., Taymaz E., Tumer T. (2007) Vision 2023: Turkey's National Technology Foresight Program: A Contextualist Analysis and Discussion // Technological Forecasting and Social Change. Vol. 74. P. 1374-1393.

Tyler R. (1942) General Statement on Evaluation // Journal of Educational Research. Vol. 35. № 7. P. 492-501.

Westat J.F. (2002) The 2002 User-Friendly Handbook for Project Evaluation. Arlington: The National Science Foundation. http://www.nsf.gov/ pubs/2002/nsf02057/start.htm (accessed 15 August 2012).

Wood J.V. (2001) UK Foresight Programme - A Panel Chairman's View. http://www.nistep.go.jp/achiev/ftx/eng/mat077e/html/mat0774e.html (accessed 07 June 2012).

Zarinpoush F. (2006) Project Evaluation Guide for Nonprofit Organizations: Fundamental Methods and Steps for Conducting Project Evaluation. Ottawa: Imagine Canada. 


\title{
The Best Practices of Evaluating S\&T Foresight: Basic Elements and Key Criteria
}

\author{
Ekaterina Makarova \\ Research Intern, Research Laboratory for Science and Technology Studies. E-mail: kmakarova@hse.ru
}

Anna Sokolova

Senior Research Fellow, Research Laboratory for Science and Technology Studies. E-mail: avsokolova@hse.ru

Institute for Statistical Studies and Economics of Knowledge, National Research University Higher School of Economics

Address: National Research University Higher School of Economics, 20, Myasnitskaya str., Moscow, 101000

\begin{abstract}
A $s$ the impact of strategic decision-making at the corporate, sectoral and national levels increase, there are growing demands for high quality and solid Foresight outputs. In this regard, a timely detection and elimination of problems in Foresight projects is of great importance. A thorough evaluation of criteria and methods used in Foresight analysis would permit the improved effectiveness of Foresight activities. The results could be set against the aims to decide on the feasibility of projects and identify ways to improve them. Despite great interest in Foresight evaluation demonstrated by stakeholders at various levels, the general principles for conducting it have not yet been formulated, which hinders its development and the diffusion of successful expertise.

The purpose of this paper is to identify the basic elements - criteria and methods - used in evaluating national Foresight. It presents the most interesting results for specific tasks, the themes examined, the

methods and the findings, in general. In addition, the study allowed some inference about theory and practice of project management. The study reveals that a key motivation for evaluation of Foresight projects is to provide feedback to national Foresight organizations and identify areas for further development. Evaluation is used to guide Foresight (in varying degrees) and provide lessons learned for future projects (for example, simplifying implementation, involving business and social organizations, recognizing the need for better compliance with the methodology and objectives of the study participants).

The paper serves to develop a general methodology for assessing national Foresight programmes. A further agenda is to develop a comprehensive analysis of Foresight, ensure comparability of results of Foresight evaluation initiatives in different countries, promote standardization of evaluation procedures.
\end{abstract}

\section{Keywords}

Foresight; evaluation; project management; best practices.

\section{References}

Aichholzer G. (2001) Delphi Austria: An Example of Tailoring Foresight to the Needs of a Small Country, Vienna: ITA.

Alsan A., Öner M.A. (2004) Comparison of National Foresight Studies by Integrated Foresight Management Model. Futures, vol. 36, no 8, pp. 889-902.

Amanatidou E., Guy K. (2008) Interpreting Foresight Process Impacts: Steps Towards the Development of a Framework Conceptualising the

Dynamics of 'Foresight Systems'. Technological Forecasting and Social Change, vol. 75, no 4, pp. 539-557.

Bennett C. (1975) Up the Hierarchy. Journal of Extension, vol. 13, no 2, pp. 7-12.

Bezold C. (2010) Lessons from Using Scenarios for Strategic Foresight. Technological Forecasting and Social Change, vol. 77, no 9, pp. 1513-1518.

Björn L., Lübeck L. (2003) Swedish Technology Foresight - A Successful Project With Many Lessons Learned. Paper presented at the Second International Conference on Technology Foresight, 27-28 February, Tokyo.

BMBF (2002) Futur Lead Visions Complete Document, Berlin: German Ministry for Education and Research.

Bohanec M., Rajkovič V., Semolič B., Pogačnik A. (1995) Knowledge-Based Portfolio Analysis for Project Evaluation. Information \& Management, vol. 28, no 5, pp. 293-302.

Calof J., Smith J.E. (2008) Critical Success Factors for Government Led Foresight. Paper presented at the Third International Seville Seminar on Future Oriented Technology Analysis: Impacts and Implications for Policy and Decision-Making, Seville, October 16-17.

CROWN (2009) Multi-Criteria Analysis: A Manual, London: Department of Communities and Local Government.

Cuhls K. (2003) From Forecasting to Foresight Processes - New Participative Foresight Activities in Germany. Journal of Forecasting, vol. 22, pp. 93-111.

Cuhls K., Georghiou L. (2004) Evaluating a Participative Foresight Process: “Futur — The German Research Dialogue”. Research Evaluation, vol. 13, no 3, pp. 143-153.

Daim T., Basoglu N., Dursun O., Saritas O., Pisek G. (2009) A Comprehensive Review of Turkish Technology Foresight Project. Foresight, vol. 11, no 1 , pp. 21-42.

Destatte P. (2007) Evaluation of Foresight: How to Take Long-Term Impacts into Consideration? Paper presented at FOR-LEARN Mutual Learning Workshop-Evaluation of Foresight, 19 September, Brussels.

Dursun O., Türe T.E., Daim T.U. (2011) Post-Evaluation of Foresight Studies: Turkish Case. International Journal of Foresight and Innovation Policy, vol. 7, no 4, pp. 311-337.

Eilat H., Golany B., Shtub A. (2008) R\&D Project Evaluation: An Integrated DEA and Balanced Scorecard Approach. Omega International Journal of Management Science, vol. 36, no 5, pp. 895-912. 
European Commission (1999) Evaluation of Socio-Economic Programmes. Glossary of 300 Concepts and Technical Terms. Luxembourg: "Means" Collection.

FOR-LEARN - On Line Foresight Guide. Available at: http://forlearn.jrc.ec.europa.eu/guide/7_cases/futur.htm (accessed 27 July 2012)

Georghiou L. (2003) Evaluating Foresight and Lessons for Its Future Impact. Paper presented at The Second International Conference on Technology Foresight, 27-28 February, Tokyo.

Georghiou L., Acheson H., Cassingena Harper J., Clar G., Klusacek K. (2004a) Evaluation of the Hungarian Technology Foresight Programme (TEP). Report of an International Panel, Manchester: PREST, University of Manchester.

Georghiou L., Clarysse B., Steurs G., Bilsen V., Larosse J. (2004b) Making the Difference - The Evaluation of Behavioural Additionality of RßD Subsidies, Brussels: IWT Vlaanderen, IWT Studies 48.

Georghiou L., Keenan M. (2006) Evaluation of National Foresight Activities: Assessing Rationale, Process and Impact. Technology Forecasting and Social Change, vol. 73, no 7, pp. 761-777.

Georghiou L., Cameron H., Keenan M., Miles I., Saritas O. (2006) An Evaluation of the UK Foresight Programme: Final Report, Manchester: PREST, University of Manchester.

Giesecke S. (2008) Futur - The German Research Dialogue. The European Foresight Monitoring Network. Collection of EFMN Briefs (eds. S. Giesecke, P. Crehan, S. Elkins). Part 1, Luxembourg: Office for Official Publications of the European Communities.

Godinho P.C., Afonso A.R., Costa J.P. (2004) On the Use of Multiple Financial Methods in the Evaluation and Selection of Investment Projects. Investigação Operacional, vol. 24, no 1, pp. 1-20.

Guba E., Lincoln Y. (1989) Fourth Generation Evaluation, London: Sage Publications.

Habegger B. (2010) Strategic Foresight in Public Policy: Reviewing the Experiences of the UK, Singapore, and the Netherlands. Futures, vol. 42, no 1 , pp. 49-58.

Havas A., Schartinger D., Weber K.M. (2007) Experiences and Practices of Technology Foresight in the European Region. Paper presented at the UNIDO Technology Foresight Summit 2007, 27-29 September, Budapest.

Havas A., Schartinger D., Weber A. (2010) The Impact of Foresight on Innovation Policy-Making: Recent Experiences and Future Perspectives. Research Evaluation, vol. 19, no 2, pp. 91-104.

HM Treasury (2003) The Green Book: Appraisal and Evaluation in Central Government, London: TSO.

JICA (2004) JICA Guideline for Project Evaluation (September 2004), Japan International Cooperation Agency, pp. 141-145. Available at: http:// www.jica.go.jp/english/operations/evaluation/tech_and_grant/guides/guideline.html (accessed 15 August 2012).

Kováts F. (2000) The Hungarian Technology Foresight Programme. Report by the Steering Group, Budapest.

Kuwahara T., Kameoka A., Yokoo Y. (2004) A challenge of integrating technology foresight and assessment in industrial strategy development and policymaking. Technological Forecasting and Social Change, vol. 71, no 6, pp. 579-598.

Li S.S., Kang M.H., Lee L.C. (2009) Developing the Evaluation Framework of Technology Foresight Program: Lessons Learned from European Countries. Paper presented at the Atlanta Conference on Science and Innovation Policy, Atlanta, October 2-3.

Lindgren M., Bandhold H. (2003) Scenario Planning: The Link Between Future and Strategy, Hampshire: Palgrave Macmillan.

Medina J. (2006) Colombian Program on Technological and Industrial Foresight: Achievements and Perspectives, Bogotá: Colciencias.

Meissner D., Cervantes M. (2008) Results and Impact of National Foresight Studies. Paper presented at the Third International Seville Seminar on Future Oriented Technology Analysis: Impacts and Implications for Policy and Decision-Making, Seville, October 16-17.

Meissner D., Cervantes M. (2010) Uspeshnyi Forsait: dizain, podgotovka, instrumentarii [Successful Foresight Study: Implications for Design, Preparatory Activities and Tools to Use]. Foresight-Russia, vol. 4, no 1, pp.74-81.

Meissner D. (2012) Results and impact of national Foresight-studies. Futures (forthcoming).

Miles I. (2002) Appraisal of Alternative Methods and Procedures for Producing Regional Foresight. Report prepared by CRIC for the European Commission's DG Research funded STRATA - ETAN Expert Group Action, Manchester.

Miles I. (2003) Ten Years of Foresight in the UK. Paper presented at NISTEP Second International Conference on Technology Foresight, Tokyo, February 27-28.

Miles I. (2008) Razrabotka stsenariev i dorozhnykh kart dlya klyuchevykh tekhnologii: preduprezhdenie navodnenii i zashchita beregovykh territorii v Velikobritanii [Scenarios and Road Mapping for Key Technologies: Flood and Coastal Defense in Great Britain]. Foresight-Russia, vol. 2, no 4, pp. 50-59.

Mishra S. (2009) Engineering Economics and Costing, New Delhi: PHI Learning Private Limited.

Owen J., Lambert F. (1998) Evaluation and the Information Needs of Organizational Leaders. American Journal of Evaluation, vol. 19, no 3 , pp. 355-365.

Phillips J.J., Bothell T.W., Snead G.L. (2002) The Project Management Scorecard: Measuring the Success of Project Management Solutions, Woburn: Butterworth-Heinemann.

PMI (1996) A Guide to the Project Management Body of Knowledge, Newton Square, PA: Project Management Institute.

Popper R. (2008) Foresight Methodology. The Handbook of Technology Foresight (eds. L. Georghiou, J. Cassingena, M. Keenan, I. Miles, R. Popper), Cheltenham: Edward Elgar.

Popper R. (2009) Mapping Foresight: Revealing How Europe and Other World Regions Navigate into the Future, EFMN, Luxembourg: Publications Office of the European Union, European Commission.

Popper R., Georghiou L., Keenan M., Miles I. (2010) Evaluating Foresight: Fully-Fledged Evaluation of Colombian Technology Foresight Programme, Santiago de Cali: Universidad del Valle.

Rader M. (2003) Hungary - Hungarian Foresight Programme (TEP) 1997/99. FISTERA report WP 1 - Review and Analysis of National Foresight D1.1. HU - Case Study.

Remer D.S., Nieto A.P. (1995) A Compendium and Comparison of 25 Project Evaluation Techniques. Part 1: Net Present Value and Rate of Return Methods. International Journal of Production Economics, vol. 42, no 1, pp. 79-96.

Remer D.S., Nieto A.P. (1995) A Compendium and Comparison of 25 Project Evaluation Techniques. Part 2: Ratio, Payback and Accounting Methods. International Journal of Production Economics, vol. 42, no 2, pp. 101-129.

Remer D.S., Stokdyk S.B., Driel M.V. (1993) Survey of Project Evaluation Techniques Currently Used in Industry. International Journal of Production Economics, vol. 32, no 1, pp. 103-115.

Ricker K.T., Brown L.C., Leeds C.F., Leeds R.P., Bonar Bouton E.K., Volgstadt C.E. (1998) Water Quality Project Evaluation: A Handbook for Objectives-Based Evaluation of Water Quality Projects. Available at: http://ohioline.osu.edu/b868 (accessed 13 July 2012).

Rollwagen I., Hofmann J., Schneider S. (2008) Improving the Business Impact of Foresight. Analysis \& Strategic Management, vol. 20, no 3, pp. 337-349.

Saritas O. (2006) Systems Thinking for Foresight. PhD Thesis, The University of Manchester.

Saritas O., Taymaz E., Tumer T. (2007) Vision 2023: Turkey’s National Technology Foresight Program: A Contextualist Analysis and Discussion. Technological Forecasting and Social Change, vol. 74, pp. 1374-1393.

Tyler R. (1942) General Statement on Evaluation. Journal of Educational Research, vol. 35, no 7, pp. 492-501.

Westat J.F. (2002) The 2002 User-Friendly Handbook for Project Evaluation, Arlington: The National Science Foundation. Available at: http://www. nsf.gov/pubs/2002/nsf02057/start.htm (accessed 15 August 2012).

Wood J.V. (2001) UK Foresight Programme - A Panel Chairman's View. Available at: http://www.nistep.go.jp/achiev/ftx/eng/mat077e/html/ mat0774e.html (accessed 7 June 2012).

Zarinpoush F. (2006) Project Evaluation Guide for Nonprofit Organizations: Fundamental Methods and Steps for Conducting Project Evaluation, Ottawa: Imagine Canada. 


\section{Взаимосвязи между акторами инновационной системы}

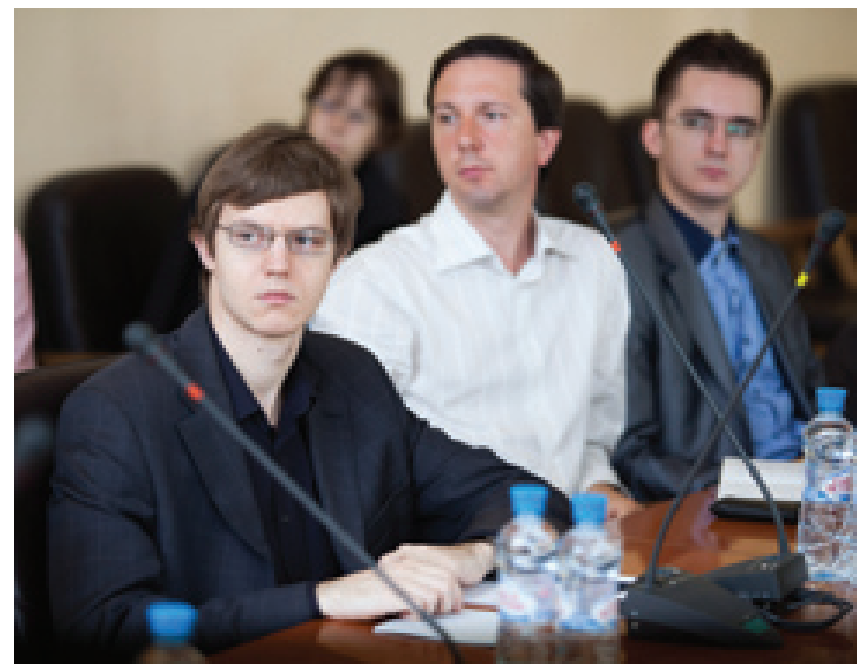

Новейшие исследования влияния отдельных элементов инновационной системы на ее динамику стали предметом обсуждения на международном семинаре «Взаимосвязи между акторами инновационной системы», прошедшем в НИУ ВШЭ в середине июня 2012 г.

Мероприятие было организовано Лабораторией экономики инноваций Института статистических исследований и экономики знаний (ИСИЭЗ НИУ ВШЭ). В нем приняли участие ведущие зарубежные ученые из Великобритании, Норвегии и Швеции, сотрудники НИУ ВШЭ и другие специалисты.



ткрывая дискуссию, первый проректор НИУ ВШЭ и директор ИСИЭЗ Леонид Гохберг представил основные направления деятельности Института. ИСИЭЗ был основан в 2002 г. с целью осуществления комплексных исследований в области статистики, анализа и прогнозирования сферы науки и инноваций, научнотехнической и инновационной политики. Тематика работ охватывает:

- развитие теории, методов и практики статистических измерений науки, технологий, инноваций, образования, информационного общества;

- сопоставительный анализ тенденций развития указанных сфер в России и за рубежом;

- исследование механизмов и инструментов научнотехнической и инновационной политики.

- долгосрочное прогнозирование (Форсайт) и определение приоритетов научно-технологического, инновационного и социально-экономического развития на федеральном, региональном, отраслевом и корпоративном уровнях.

Помимо исследовательской деятельности специалисты Института оказывают экспертно-аналитическую

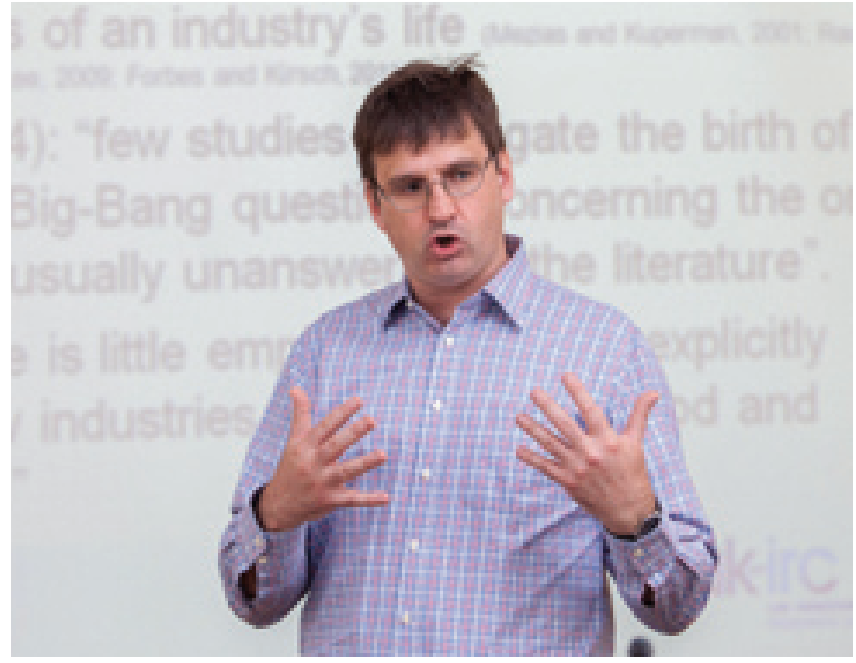

поддержку органам власти по реформированию сферы науки, технологий и инноваций, участвуют в разработке различных документов федерального и регионального уровней. За годы существования ИСИЭЗ превратился в ведущий научный центр, результаты деятельности которого широко публикуются в монографиях, аналитических и статистических изданиях, ведущих российских и зарубежных научных журналах. Сотрудниками Института сформированы и поддерживаются уникальные базы данных в области научно-технологического и инновационного развития, построения экономики знаний, в том числе полученные на основе собственных эмпирических исследований. ИСИЭЗ эффективно взаимодействует с зарубежными партнерами, включая международные организации (ОЭСР, Евростат, Европейская комиссия, ЮНЕСКО, ЮНИДО, ЮНКТАД, Всемирный банк и др.); ведущие университеты, исследовательские центры и компании.

Л. Гохберг объяснил организационную структуру Института, подробно рассказал о специализации недавно созданных подразделений, имеющих непосредственное отношение к проводимому семинару. В составе ИСИЭЗ функционируют девять исследовательских центров, а с 2011 г. - еще и две международные лаборатории под руководством авторитетных зарубежных ученых: Лаборатория исследований науки и технологий (руководитель - Жан Гине) и Лаборатория экономики инноваций (руководитель - Йен Майлс). В лабораториях проводятся исследования, направленные на развитие теоретических подходов, моделей и аналитического инструментария для изучения сферы науки, технологий и инноваций, совершенствование методов и инструментов доказательной политики в этих направлениях.

В первом тематическом докладе семинара Брюс Тетер (Университет Манчестера, Великобритания) представил анализ взаимосвязей между предпринимательской деятельностью и возникновением новых секторов. Несмотря на широкое использование понятия «жизненный цикл отрасли», о процессе их зарождения известно немного. 
В пределах одной отрасли потребители могут выбирать различных производителей товаров или услуг, существенно не изменяя своих запросов. В данном случае возникают вопросы о характеристиках «первопроходцев» и влиянии их поведение на формирование сектора.

Б. Тетер подчеркнул, что в теории предпринимательства при изучении процесса формирования новых секторов акцент сделан, главным образом, на наличии выгодных возможностей и предприимчивых индивидуумов, которые их находят, оценивают и используют с целью получения материальной выгоды (прибыли). Эти положения сформулированы в работах Кассона, Кирцнера и других ученых еще в 1970-80-х гг. (discovery-based theory). Но для зарождающихся секторов убедительнее звучат подходы, акцентирующие важность обеспечения условий для развития активного созидательного процесса (creation-based theories). По мнению докладчика, для понимания факторов, влияющих на зарождение отрасли, нельзя игнорировать значение эмоциональных аспектов и неоценочных мотивов, которыми руководствуются предприниматели.

Так, анализ формирующегося в Великобритании рынка консалтинга в сфере дизайна позволил Б. Тетеру опровергнуть конвенциональные представления о том, что бизнес действует лишь в границах существующих рынков, и выявить факторы, влияющие на эволюцию новых отраслей. В рамках качественного исследования была проведена серия интервью с руководителями компаний, которые стояли у истоков развития сектора дизайна услуг, возникшего около десяти лет назад. Его деятельность подразумевает планирование и организацию человеческих ресурсов, инфраструктуры, коммуникаций и материального обеспечения для улучшения качества услуги и взаимодействия между ее поставщиками и потребителями.

Эмпирические сведения дополнялись опросом клиентов, сотрудников и специалистов отрасли. Б. Тетер подробно рассказал о кейсах, свидетельствующих, что новый рынок дизайна услуг сформировался не на основе существующих возможностей, а исключительно за счет усилий, эмоциональной вовлеченности и заинтересованности компаний-«пионеров». При этом предприниматели ориентировались не на оптимальный климат, а на доступные в момент принятия решения ресурсы. Свою деятельность они организовали, руководствуясь не только целью максимизации прибыли, но и стремлением выстроить сотрудничество с сообществом специалистов, содействовать расширению потенциального числа игроков новой сферы. Аналогичное поведение характерно и для других возникающих секторов. По прохождении фазы зарождения второе поколение предпринимателей располагает легитимными условиями для планирования деятельности на основании уже существующих возможностей.

В заключение Б. Тетер отметил, что результаты исследования оставляют открытым вопрос, насколько предприниматели - основоположники новых отраслей, отличаются от «стандартных» руководителей, действующих в рамках существующих секторов по алгоритму «открытие - оценка - использование возможностей».

Краткий обзор эмпирических исследований Института в сфере науки, технологий и инноваций представили Константин Фурсов и Виталий Рудь (ИСИЭЗ НИУ ВШЭ).
В первой части доклада К. Фурсов описал задачи и основные принципы организации научной деятельности ИСИЭЗ по изучению особенностей функционирования и развития в России экономики знаний. Созданная в этих целях система обследований включает широкий спектр регулярных статистических наблюдений и серию специализированных мониторинговых проектов (анализ карьеры и мобильности научных кадров высшей квалификации, инновационного поведения населения, участников инновационного процесса и др.). Принимая во внимание сложность экономики знаний как предметной области, особое внимание уделяется адекватному описанию объектов исследования; релевантности целям научно-технической и инновационной политики; комплексности системы показателей; интеграции различных методов наблюдения и анализа; гибкости методов сбора и обработки данных; международной сопоставимости ключевых индикаторов.

Статистические работы, которые ведутся коллективом ИСИЭЗ в соответствии с мировой практикой, позволяют получить сведения о ресурсах, направляемых в сферу науки, технологий и инноваций, результатах деятельности игроков инновационного процесса; обеспечить информационную основу для принятия управленческих решений. Реализуемые проекты нацелены на анализ специфических аспектов функционирования национальных инновационных систем и моделей поведения ее агентов, что позволяет систематизировать закономерности развития экономики знаний.

К. Фурсов особо отметил организацию статистических наблюдений. Так, в 2009 г. ИСИЭЗ инициировал масштабный проект по формированию в России системы статистики нанотехнологий, включающий разработку базовых определений, подходов к классификации и статистическому измерению особенностей функционирования и развития данной технологической области. Наблюдения охватывают весь инновационный цикл - от исследований и разработок до выпуска продукции с применением нанотехнологий. Результаты проекта были представлены на совещании Группы национальных экспертов по индикаторам науки и технологий ОЭСР и положены в основу международной программы работ по формированию статистики новых и возникающих технологий.

Докладчик также уделил внимание комплексу мониторинговых проектов, реализуемых коллективом ИСИЭЗ в рамках Программы фундаментальных исследований НИУ ВШЭ. В 2012 г. их список пополнился обследованиями в секторе исследований и разработок, которые выполняются по заказу Минобрнауки. В совокупности они образуют мониторинг экономики науки. Инициатива носит экспериментальный характер и выступает в качестве платформы для отработки новых инструментов статистических и социологических измерений в сфере науки, технологий, инноваций.

В. Рудь рассказал о специализированном мониторинге деятельности субъектов инновационного процесса. Объект исследования - научные организации и предприятия реального сектора экономики (промышленного производства, а также ряда направлений сферы услуг); основная цель - предложить новые метрики, описывающие инновационное поведение ключевых акторов. Важной особенностью проекта является обеспечение совместимости его инструментария и результатов с 
Европейским обследованием промышленности (European Manufacturing Survey), проходящим в 15 странах. Анализ полученной информации ориентирован на изучение инновационных стратегий предприятий и организаций, сетевых взаимодействий, особенностей реализации процессных инноваций в компаниях, явления сервисизации промышленности. Его результаты использовались для подготовки научных публикаций и рекомендаций по совершенствованию научно-технической и инновационной политики.

Доклад Марины Дорошенко (ИСИЭЗ НИУ ВШЭ) был посвящен проблемам развития сектора интеллектуальных услуг в России и их значению для повышения инновационной активности бизнеса. На основе данных, собранных в ходе опросов российских производителей и потребителей таких услуг было показано, что зачастую они сами генерируют большое число инноваций. Доля инновационной продукции в выпуске компаний сектора значительно превышает среднюю по экономике и сопоставима с наиболее инновационными отраслями промышленности. Последний финансово-экономический кризис лишь стимулировал инновационную активность в данной сфере, поскольку она рассматривались производителями интеллектуальных услуг как важнейшее условие выживания.

Очевидно, что влияние интеллектуальных услуг на инновации не исчерпывается сервисными новшествами. Благодаря активному участию потребителей в производстве (совместном производстве) этих услуг компаниизаказчики быстро переходят в группу инновационных, поскольку овладевают новыми знаниями и практиками, освоенным в ходе «сопроизводства». Не менее половины респондентов подчеркнули значимое позитивное влияние такого опыта на склонность к инновациям. В итоге сектор интеллектуальных услуг становится генератором не только собственных, но и внешних инноваций как технологического, так и сервисного характера.

Логическим продолжением презентации результатов работ Института стал доклад Станислава Заиченко (ИСИЭЗ НИУ ВШЭ), посвященный вкладу государственных научных учреждений в развитие инновационной деятельности компаний. Он представил обзор итогов аналитических работ по изучению особенностей организации процесса передачи знаний (технологий), созданных отечественными научными организациями, предприятиям реального сектора экономики. Анализ основывался на уникальной информационной базе, сформированной в ходе мониторинга инновационной деятельности научных организаций в 2010-2011 гг.

Докладчик рассмотрел основные теоретико-методологические предпосылки статистических исследований инновационной деятельности научных организаций с использованием микроданных. На примере успешных зарубежных практик были обозначены ключевые исследовательские задачи и пути их решения с учетом актуальных проблем развития научно-инновационной сферы.

Отталкиваясь от результатов пилотных обследований, С. Заиченко продемонстрировал роль анализа деятельности научных структур по трансферу технологий в контексте развития общего подхода к оценке их эффективности на микроуровне. В ряде случаев индивидуальные стратегии трансфера определяют эффективность научной деятельности конкретных организаций. Дискуссия развернулась вокруг таксономии индивидуальных стратегий передачи научно-технических результатов (формы трансфера и уровень новизны технологий), рыночного позиционирования (модели конкурентного поведения, выбор рыночных ниш, взаимодействие с потребителями) и способов организации передачи (контроль качества, связи с организационными стратегиями, уровень анализа рынков).

Одним из наиболее примечательных выводов стала констатация фактического отсутствия у российских научных организаций стратегий достижения международного лидерства в прорывных технологических направлениях. Это подтверждает актуальность акцента на инструменты государственной политики по приоритетной поддержке национальных центров превосходства.

В заключение выступавший описал возможности применения разработанного теоретико-методологического подхода для анализа региональных паттернов стратегий передачи научно-технических результатов в реальный сектор. На уровне описательных статистик выделены характерные типы региональных систем передачи знаний. Типология формировалась с учетом комплексных региональных характеристик интенсивности и структуры технологического обмена, барьеров и механизмов его поддержки, а также доминирующих стратегий трансфера, описанных в терминах конкурентной среды, кооперационных связей, степени новизны технологий, контроля качества и пр. Полученные результаты иллюстрируют потенциал имеющейся эмпирической базы, в том числе для формирования рекомендаций в области научно-технической и инновационной политики, корректирования исследовательских задач и т. д.

Второй день семинара начался с презентации Яна Фагерберга (Университет Осло, Норвегия), широко известного работами по изучению взаимосвязей между инновациями, распространением технологий и экономическим ростом. Рассматривались условия и факторы догоняющего развития. Исследователь подчеркнул, что курс на становление политической системы западного типа, либерализацию внешней торговли и снятие ограничений для прямых иностранных инвестиций не является достаточным условием для обеспечения экономического роста. Подобные инициативы эффективны для развитых стран, однако в случае развивающихся государств часто не играют решающей роли. Вследствие того что основой современной экономической модели являются знания, ее успех невозможно повторить лишь путем заимствования практик западных институтов. Распространение знаний многоуровневый процесс с большим числом акторов, в котором возможности и условия для их усвоения приобретают особую значимость. Так, Линсу Ким ввел понятие «технологические способности страны» (technology capacities), а Мозес Абрамовитц — «социальные способности» (social capacities). К первым относят инновационный, производственный и финансовый потенциал. При определении «социальных способностей» учитываются качество образования, инженерных и технологических навыков; развитость коммерческих, промышленных и финансовых институтов; другие характеристики, влияющие на риски, стимулы и выгоду от экономической деятельности. Докладчик представил индикаторы для измерения этих составляющих, предложив оценивать, наряду с технологическими и социальными способностями, «открытость» 
(во внешней торговле, по отношению к прямым иностранным инвестициям и т. д.). В результате основанного на предложенных показателях факторного анализа траекторий развития 115 стран за период 1992-2004 гг. Я. Фагерберг выделил критические условия экономического прогресса. К ним относятся эффективная инновационная система и государственное регулирование, ориентированное на поддержку инноваций.

В ходе дискуссии об особенностях выбранных индикаторов Я. Фагерберг отметил, что в данный момент работает над включением в исследуемую модель новых социокультурных факторов (таких как религиозность).

Сессию продолжили сотрудники Лаборатории экономики инноваций НИУ ВШЭ. Виталий Рудь рассказал о результатах эмпирических исследований микроданных по инновационному поведению российских промышленных компаний. Современное понимание природы инновационных процессов основывается на использовании подходов и методов ряда научных дисциплин, включая экономику, социологию, менеджмент, психологию. Подобное сложное представление определяет вызов для исследователей инновационной сферы, вынуждая их балансировать между полнотой описания и ограниченными возможностями конкретного обследования. По мнению докладчика, одним из методов разрешения данной проблемы могут стать типологии инновационного поведения предприятий, построенные на основе статистического анализа дезагрегированных микроданных. Он представил концептуальную схему анализа особенностей поведения компаний, основанную на типологическом подходе, а также опыт ее реализации на российских статистических данных. Среди основных эмпирических выводов выделены: рост эффективности вложений в инновации при повышении их «качества» (степени новизны); неразвитость кооперационных связей для всех типов инновационных компаний, кроме наиболее продвинутых; существенное разнообразие типов инноваторов в терминах восприятия проблем национальной инновационной системы и спроса на меры государственной политики.

Томас Гштраунталер и Елена Ветчинкина (ИСИЭЗ НИУ ВШЭ) представили результаты исследования технологического и инновационного развития крупных компаний. Е. Ветчинкина остановилась на теоретических и методологических принципах технологического аудита предприятий, используемых при формировании стратегии инновационного развития и определении необходимой для ее реализации ресурсной, производственной, организационной и информационной базы.

Технологический аудит представляет собой комплексную специализированную оценку конкурентоспособности производственной и инновационной деятельности компании, реализуемую в контексте планирования инновационного развития и проведения модернизации. При этом изучаются три основные составляющие - ресурсная, процессная, результирующая. Для оценки технологического уровня применяются различные индикаторы, описывающие производство, научно-техническую и инновационную активность. Использование индексов позволяет предприятию получить информацию об изменении эффективности деятельности (от прошлого к будущему); соотнести себя с конкурентами внутри отрасли; проводить нормативный анализ и устанавливать целевые ориентиры. По результатам оценки технологического уровня, с учетом особенностей внутренней организации бизнес-процессов и взаимодействия с внешней инновационной средой, принимается решение об инновационнотехнологической стратегии.

Т. Гштраунталер охарактеризовал современные тенденции развития российских компаний топливно-энергетического сектора, их роль в экономике, особенности внутренней организации, уровень технологической и инновационной активности. Сегодня в России реализация углеводородов дает 85\% поступлений от внешнеэкономической деятельности и порядка $30 \%$ доходной части бюджета. Добывающие производства ТЭК традиционно относятся к «низкотехнологичным» секторам. Совокупная доля инновационной активности добывающих компаний составляет менее $10 \%$ (8.5\% в 2009 г. и 9.7\% в 2010 г.). Удельный вес инновационных товаров, работ и услуг не превышает 3\% общего объема производства продукции по данному виду экономической деятельности $(2.7 \%$ в 2009 г. и $3.0 \%$ в 2010 г.). Докладчик представил результаты совместного с С. Заиченко исследования способов конкуренции научных организаций, относящихся к первичному сектору экономики, на рынках технологий, включая формы и каналы трансфера, схемы взаимодействий с партнерами.

В заключение Е. Ветчинкиной и Т. Гштраунталером были рассмотрены результаты анализа стратегий «зеленого» роста (green growth) для производителей нефтегазового сектора в качестве проблемно-ориентированного подхода к измерению технологического уровня. После инцидента в Мексиканском заливе в 2010 г. связь между социально-экологическим аспектом устойчивости нефтегазовых компаний (corporate sustainable development) и их финансово-экономическим положением стала очевидной. В настоящее время иностранные и отечественные предприятия ТЭК под влиянием внешних и внутренних факторов на уровне долгосрочной стратегии развития, управленческих практик, результатов инновационной деятельности внедряют элементы, способствующие «зеленому» росту. Изменения видны и на нормативном уровне: от ужесточения отраслевой национальной законодательной базы относительно воздействия нефтегазовых компаний на окружающую среду до увеличения числа рамочных документов, упорядочивающих концепции и способы измерения «зеленой» экономики (green economy) на международном уровне. Среди многочисленных примеров - публикации ОЭСР и Программы ООН по окружающей среде (UNEP) ${ }^{1}$.

На примере анализа отчетности нескольких ведущих иностранных и российских нефтегазовых компаний в среднесрочном периоде предложены индикаторы для измерения «зеленого» роста компаний ТЭК; изучено их использование в качестве средства коммуникации с основными стейкхолдерами.

Выбранные показатели позволяют говорить об операционализации стратегии «зеленого» роста нефтегазовых компаний с детализацией до отдельных компонент (к примеру, уровня загрязнений водной и воздушной среды, использования топливно-энергетических и иных 
видов ресурсов, штрафов за загрязнения и инвестиций в природоохранную деятельность). В целом стратегии «зеленого» роста и их элементы можно оценивать в терминах зрелости, сложности, активности или пассивности, режимов лидерства или следования, различной степени диверсификации компонент и масштабов их изменения.

Наталья Шматко и Ольга Шувалова (ИСИЭЗ НИУ ВШЭ) ознакомили аудиторию с эмпирическими исследованиями компетенций акторов национальной инновационной системы, а также инновационных навыков экономически активных образованных россиян. Исследования проводились в 2011 г. на базе Российского мониторинга экономического положения и здоровья населения (РМЭЗ) в рамках Программы фундаментальных исследований НИУ ВШЭ.

Н. Шматко описала методологические особенности проекта, подчеркнув его отличия от применявшихся ранее подходов, направленных на изучение системы ценностей при помощи методики психологического тестирования. Анализировалось фактическое применение определенных умений специалистов, вовлеченных в инновации. Для этого были выделены шесть групп навыков - технологические, когнитивные и информационные, управленческие, маркетинговые, предпринимательские и коммуникационные. К ним была добавлена седьмая группа личных качеств (креативность, лидерство, энергичность, уверенность в себе, предрасположенность к риску, толерантность).

В задачи исследования входило построение профилей по уровню полномочий (ответственности) и позиции (роли) в инновационном процессе. По последнему критерию выделены пять категорий работников: «инициатор», «разработчик-исследователь», «исполнитель», «член команды», «не участвовал».

О. Шувалова рассказала о количественных характеристиках участия респондентов в создании инноваций в роли инициаторов, членов команды и исполнителей с описанием навыков и личных качеств. Так, группа инициаторов охватила более трети выборочной совокупности, но лишь у 16\% из них предложения по усовершенствованию какого-либо направления деятельности были успешно доведены до конца (подгруппа успешных инициаторов). Наиболее активных инициаторов отличает высокая степень вовлеченности в создание и применение передовых технологий, интерес к новейшим трендам; они обладают хорошими управленческими и организационными знаниями, включены в маркетинговую деятельность и т. д. Единственное, в чем они не отличаются от других респондентов - низкий уровень либо полное отсутствие владения иностранным языком, что создает барьеры для эффективной интеграции в международные кооперационные процессы.

Успешные члены команды (обсуждали и поддерживали новые идеи - 17\% выборки) не уступают по набору основных умений и навыков инициаторам разработок; половина из них таковыми и являются. Отмечены лишь менее выраженные лидерские качества и склонность к риску.

Исполнители - лица, использующие современное оборудование и эффективные методы работы, - составили
44\% выборочной совокупности; характеризуются молодостью, интенсивным использованием специализированных Интернет-ресурсов, хорошим владением иностранными языками. Однако по уровню базовых компетенций они значительно отстают от инициаторов и членов команды.

Наконец, 11\% респондентов оказались абсолютно не задействованными в инновационной деятельности. Чаще всего это женщины и лица со средним профессиональным образованием. Результаты опроса свидетельствуют о крайне низком уровне либо отсутствии у них знаний и умений, необходимых для инновационного процесса.

Семинар завершил Чарльз Эдквист, основатель одного из ведущих международных исследовательских центров в рассматриваемой области - Centre for Innovation, Research and Competence in the Learning Economy (CIRCLE), Lund University, Sweden. Продолжая исследования Б.-А. Люндваля, К. Фримена и Р. Нельсона, Ч. Эдквист внес весомый вклад в развитие аналитических подходов к изучению инновационной деятельности, предложив концепцию «систем инноваций» (systems of innovation). Он рассказал о применении данного подхода при разработке инновационной политики, начав с определения базовых понятий. К инновациям Ч. Эдквист относит новые продукты и процессы, обладающие экономической или социальной значимостью и осуществляемые, главным образом, компаниями (при определенном взаимодействии с другими игроками). Система инноваций охватывает «все важные экономические, социальные, политические, организационные и другие факторы, влияющие на развитие, распространение и использование инноваций» ${ }^{2}$. Инновационная политика рассматривается как совокупность мер госрегулирования, влияющих на генерацию и распространение инноваций, и включает в себя инструменты косвенного воздействия на эти процессы.

Ч. Эдквист подчеркнул, что в рамках систем инноваций изучаются факторы, детерминирующие инновационные процессы и инновации. Он выделил несколько ключевых положений такого подхода к исследованию эндогенных свойств инновационной деятельности, которые следует учитывать при разработке мер регулирования. Прежде всего, инновационным процессам присуще непрерывное развитие во времени. Генерация инноваций подразумевает улучшение продуктов и услуг по отношению к существующим, что определяет так называемые эволюционирующие (evolutionary) характеристики инновационных процессов. Результаты последних зависят от множества сложных факторов, влияющих на траекторию их развития (pathdependent) и не известных заранее (open-ended).

Наличие вышеперечисленных свойств инновационных процессов свидетельствует о том, что в рамках системы инноваций понятие оптимальности не релевантно, поскольку все ее составляющие непрерывно претерпевают изменения в той или иной степени. Идентификация оптимальной или идеальной системы инноваций невозможна; соответственно, сравнения на основе универсальных показателей (доля внутренних затрат на исследования и разработки (ИиР), число патентных заявок и т. п.) имеют ограниченную пользу для диагностики инновационной политики.

В качестве обоснования необходимости госрегулирования инновационной деятельности в условиях рыночной 
экономики Ч. Эдквист выделил два условия: во-первых, неспособность частных акторов самостоятельно справиться с достижением выбранных целей ${ }^{3}$, а во-вторых, наличие у государства возможностей решения проблемы или минимизации ее последствий. Подобной проблемой следует считать низкие результаты инновационной деятельности по отношению к запланированным показателям. При этом сопоставления с какой-либо «эталонной» системой инноваций нецелесообразны; гораздо продуктивнее временные сравнения состояния одной и той же системы либо сопоставления разных систем.

Как правило, цели инновационной политики формулируются в общих терминах применительно к задачам регулирования в других областях (обеспечение экономического роста и устойчивого развития, повышение уровня жизни и т. д.). Однако важно трансформировать эти установки в цели, имеющие непосредственное отношение к инновационной политике. Как отметил докладчик, операционализация целей представляется очевидным условием эффективной политики, но на практике почти не выполняется. Непосредственные цели (direct objectives) peкомендуется формулировать в терминах интенсивности инноваций (innovation intensity) для различных категорий последних (новых для рынка и для компании; инкрементальных и радикальных; инноваций в высокотехнологичных либо иных отраслях; и т. д.). Подобная задача «перевода» и детализации целей инновационной политики требует серьезной работы.

Следующий шаг после идентификации проблемы выявление факторов (causes), детерминирующих ее возникновение. Ч. Эдквист предложил рассмотреть десять направлений регулирования, распределенных по трем блокам, которые влияют на генерацию и распространение инноваций и являются обязательными составляющими комплексной инновационной политики:

I. Генерациия знаний

1) развитие сектора ИиР и производства новых знаний;

2) формирование инновационных навыков и компетенций.
II. Стимулирование спроса на инновации

3) создание новых рынков;

4) повышение стандартов качества продуктов и услуг.

III. Оптимизация условий функционирования системы инноваций

5) содействие организационным изменениям в компаниях, исследовательских институтах и государственных ведомствах;

6) развитие сетевых связей;

7) изменение институтов, влияющих на инновационную деятельность (защита интеллектуальной собственности, налоговое регулирование, стандарты, технические регламенты и т. д.);

8) обеспечение адресных инструментов поддержки инновационных компаний на ранних стадиях;

9) инструменты финансирования, облегчающие коммерциализацию результатов ИиР и трансфер знаний;

10) информационно-консультационные услуги.

По мнению Ч. Эдквиста, не всегда нужно стремиться к росту инновационной активности, по той причине, что не существует ее оптимального для всех систем уровня. Меры госрегулирования должны обеспечивать сбалансированное стимулирование тех или иных категорий инноваций и своевременную поддержку предпринимательской деятельности, связанной с высоким уровнем риска. Кроме того, целесообразно отдавать приоритет тем мерам регулирования, при помощи которых достигается максимальная синергия. Наконец, политика не должна дублировать усилия частного сектора, обеспечивая максимальную комплементарность эффектов (additionality) от взаимодействия институтов и акторов инновационной системы.

В ходе итоговой дискуссии приглашенные лекторы высоко оценили уровень проводимых в НИУ ВШЭ исследований, отметили широту эмпирических данных и многомерность методологического аппарата, выразив заинтересованность в развитии исследовательской кооперации в сфере экономики инноваций.

\section{Linkages between Actors in the Innovation System}

$\mathrm{T}$ he academic workshop «Linkages between Actors in the Innovation System» (June 13-15, 2012), organized by the HSE ISSEK Laboratory for Economics of Innovation, assessed the weight of various components of the innovation system on its overall dynamics. The event was attended by leading international researchers from the UK, Norway and Sweden, HSE representatives and other specialists. The agenda of discussions included: entrepreneurship as a driver of new industries as exemplified by service design; science, technology and innovation in Russia; knowledge-intensive business services and technology transfer as incentives for innovation in enterprises; innovation skills and behavioral patterns of key actors of the innovation system and people; technology audit; green-growth strategies for the oil-gas sector; and the design of innovation policy in a «systems of innovation» perspective. 


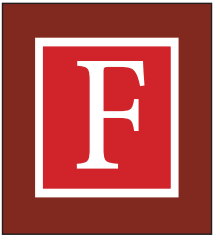

ISSN 1995-459X 